UNIVERSIDAD NACIONAL DE LA PLATA

FACULTAD DE CIENCIAS VETERINARIAS

Trabajo de Tesis realizado como requisito para optar al título de DOCTOR EN CIENCIAS VETERINARIAS

\title{
EFECTO DEL ZINC SOBRE LA MADURACIÓN DE LOS OVOCITOS DE BOVINO Y SU IMPACTO SOBRE LA CAPACIDAD DE DESARROLLO EMBRIONARIO POSTERIOR
}

\author{
AUTOR: ANCHORDOQUY, Juan Mateo \\ DIRECTOR: FURNUS, Cecilia C. \\ CODIRECTOR: PERAL GARCÍA, Pilar.
}

LUGAR DE TRABAJO: Laboratorio de Biotecnología de la Reproducción, IGEVET, Facultad de Ciencias Veterinarias (UNLP-CONICET)

MIEMBROS DEL JURADO:

Dr. LOMBARDO, Daniel.

Dra. FLAMINI, Mirta Alicia.

Dra. CORRADA, Yanina Alejandra. 


\section{Agradecimientos}

A mi directora, la Dra. Cecilia C. Furnus, quien me guió por el camino de la investigación con suma paciencia y entrega. Por su apoyo, su confianza y su inestimable ayuda, no sólo en este trabajo sino durante los años en los que he tenido el placer de trabajar a su lado. Por su amistad.

A mi codirectora, la Dra. Pilar Peral García por contribuir en mi formación profesional. Por su colaboración en el desarrollo de este trabajo.

Al Dr. Guillermo A. Mattioli por su compromiso y dedicación. Por ofrecer todos sus recursos de forma incondicional y desinteresada. Por sus innumerables consejos y su amistad.

A los Drs. Alejandro E. Relling y Mauricio Giuliodori por sus inestimables aportes estadísticos y por su paciencia infinita. Por su Amistad.

A mis amigos compañeros de ruta: Juan A. Testa, Ramiro Desantadina, Matias A. Sirini, Orlando L. Perez, Cecilia Cuitiño y Gisela Barbisan por su apoyo diario y por estimular siempre el compañerismo y el ánimo.

A Diana E. Rosa por su aporte técnico, buena voluntad y su calidez humana. Por hacerme sentir parte de su familia.

A Pato, por la paciencia, las discusiones esclarecedoras (no siempre) y la compañía permanente y muchas veces única en el laboratorio. 
A los Profs. Eduardo Desmarás y Máximo Babusci, y a todos los que forman el Curso de Fisiología por abrirme las puertas a la docencia de forma tan generosa y cálida.

Al Dr. Luis E. Fazzio por su ejemplo de conducta y claridad, por su apoyo desde el primer día. Por su amistad.

A la Dra. Analía Seoane y a Lic. Virginia Ponzinibbio por su inagotable paciencia y colaboración. Por la gran predisposición.

Al Dr. Sebastián J. Picco por su orientación.

Al Instituto de Genética Veterinaria "Ing. Fernando Noel Dulout" (IGEVET) por brindar su espacio y recursos.

A la Facultad de Ciencias Veterinarias y a la Universidad Nacional de La Plata por brindarme una formación académica de excelencia y por ceder el espacio físico donde se desarrolló este trabajo.

Al Concejo Nacional de Investigaciones Científicas y Técnicas (CONICET), por otorgarme las becas que permitieron que me dedique de manera exclusiva a mis estudios de doctorado, y por proporcionar parte de la financiación de esta tesis.

A Ceci, por su amor infinito y su compañía incondicional. Por su generosidad sin límites.

A mis viejos, mis hermanos, mis abuelos y mis amigos, por ellos viví lo que viví, conocí lo que conocí y soy este quien soy. 


\section{Publicaciones parciales del presente trabajo de tesis}

Anchordoquy JM, Anchordoquy JP, Mattioli G, Picco SJ, Rosa DE, Peral García P, Errecalde

AL, Furnus C. Importancia del Zinc durante la maduración in vitro de ovocitos: consecuencias en el desarrollo embrionario temprano. XI Congreso de la Sociedad de Ciencias Morfológicas, La Plata 17 y 18 de Septiembre de 2009. (Abstract).

Anchordoquy JM, Anchordoquy JP, Currenti LJ, Mattioli G, Rosa DE, Furnus C. Efecto del incremento en la concentración de Zinc del medio de maduración in vitro de ovocitos bovinos sobre el área de expansión del cúmulus y la tasa de desarrollo temprano. XII Congreso de la Sociedad de Ciencias Morfológicas, La Plata 16 y 17 de Septiembre de 2010. (Abstract).

Anchordoquy JM, Anchordoquy JP, Picco SJ, Seoane A, Rosa DE, Mattioli G, Peral García P, Furnus C. Efecto del medio de cultivo suplementado con diferentes concentraciones de zinc sobre la integridad del ADN y la apoptosis de células del cúmulus. $33^{\circ}$ Congreso Argentino de Producción Animal, Comarca Viedma-Patagones 13, 14 y 15 de Octubre de 2010. (Abstract).

Picco SJ; Seoane A; Anchordoquy JM; Anchordoquy JP; Rosa D; Fazzio LE; Mattioli GA; Furnus CC. Effect of zinc on DNA integrity of cumulus cells during oocyte in Vitro maturation. Journal of Basic \& Applied Genetics. 2009; 19 (2): 21-25.

Picco SJ; Anchordoquy JM; de Matos DG; Anchordoquy JP; Seoane A; Mattioli GA, Errecalde $\mathrm{AL}$; Furnus CC. Effect of increasing zinc sulphate concentration during in vitro maturation of bovine oocytes. Theriogenology. 2010; 74: 1141-1148. 
Anchordoquy JM, Picco SJ, Seoane A, Anchordoquy JP, Ponzinibio MV, Mattioli GA, Peral García P, Furnus CC. Analysis of apoptosis and DNA damage in bovine cumulus cells after exposure in vitro to different zinc concentrations. Cell Biol. Int. 2011; 35 (6): 593-7. 


\section{Índice de contenidos}

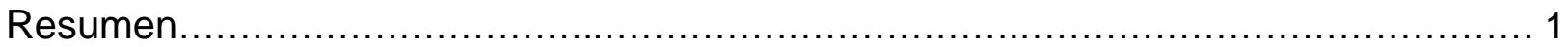

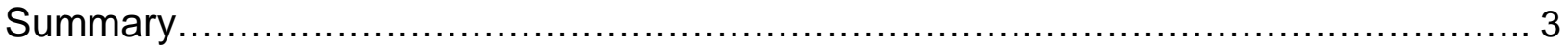

Introducción General

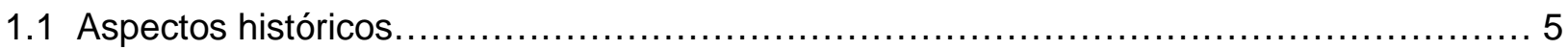

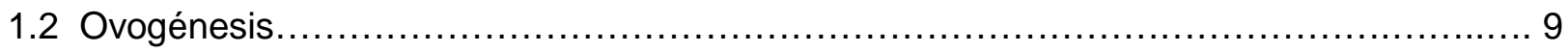

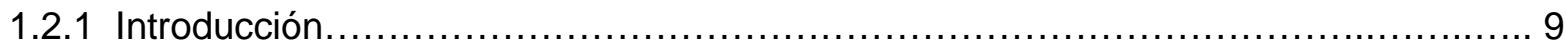

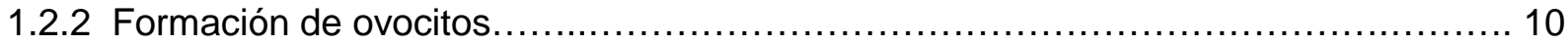

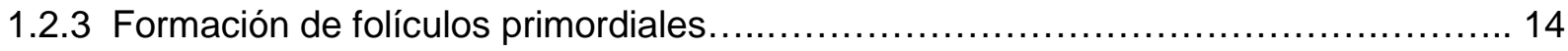

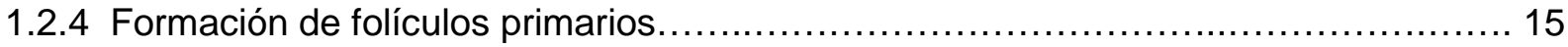

1.2.5 Crecimiento del ovocito y formación de folículos multilaminares.................... 15

1.2.6 Crecimiento del ovocito y formación de folículos antrales $\ldots \ldots \ldots \ldots \ldots \ldots \ldots \ldots \ldots \ldots \ldots$

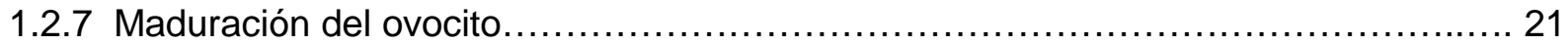

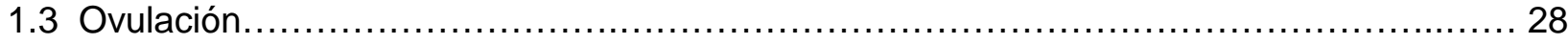

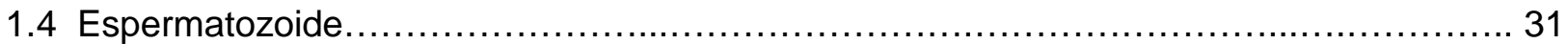

1.4.1 Características del espermatozoide de mamíferos.............................. 31

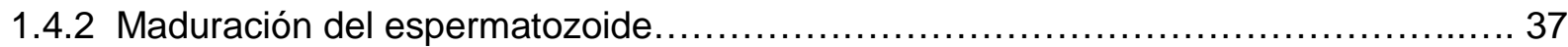

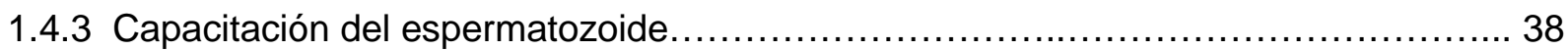

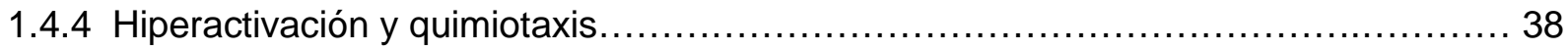

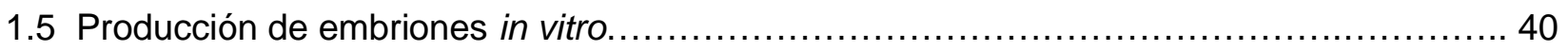

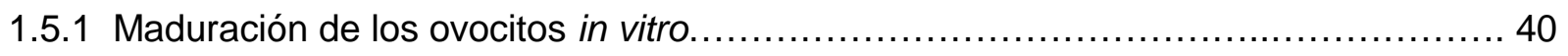




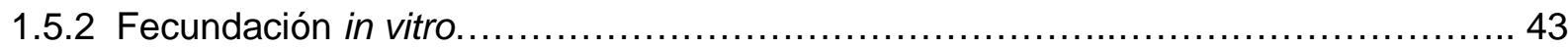

1.5.2.1 Capacitación in vitro de espermatozoides de mamífero...................... 44

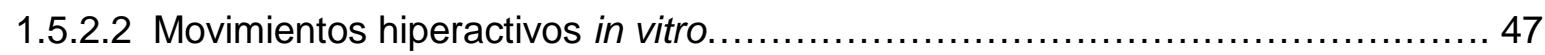

1.5.2.3 Reacción acrosómica in vitro y zona pelúcida............................. 48

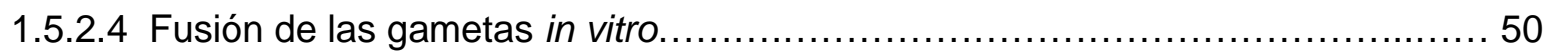

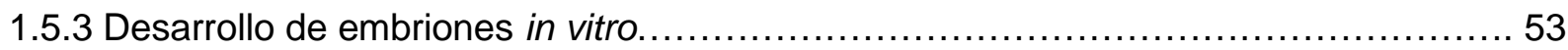

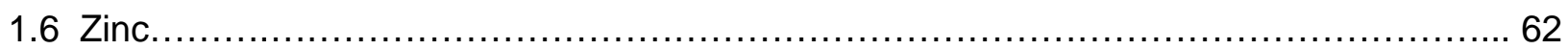

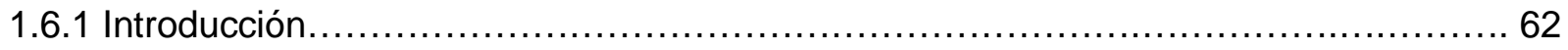

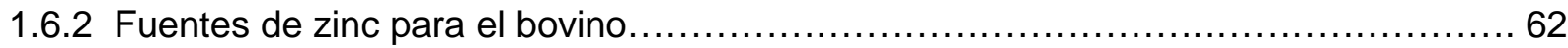

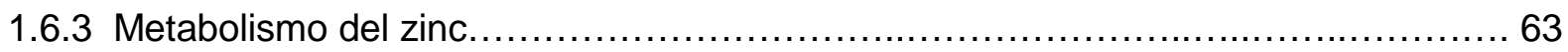

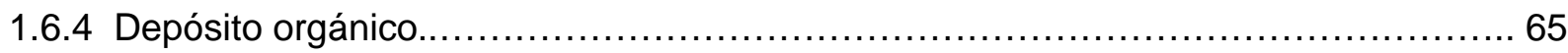

1.6.5 Pérdidas endógenas........................................................................ 66

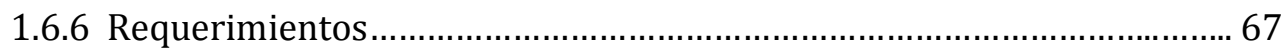

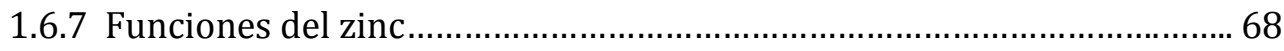

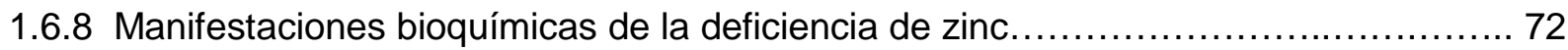

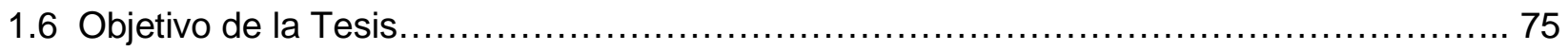

Material y Métodos

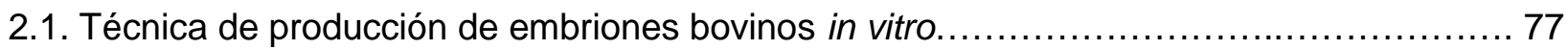

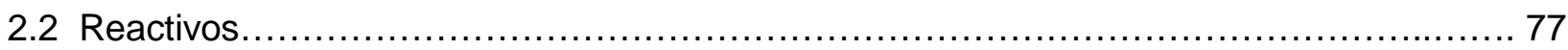

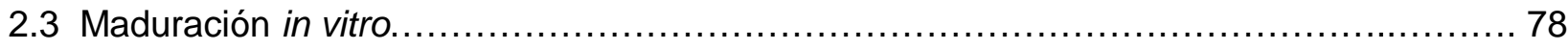

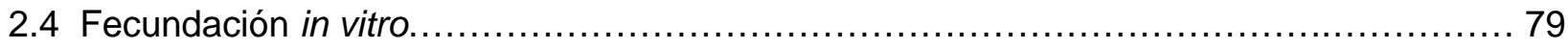

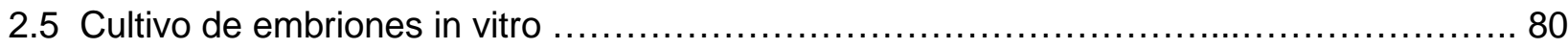

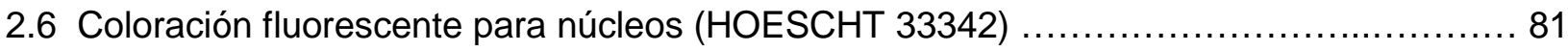




\section{Capítulo 1}

Determinación de la concentración de Zn en plasma, licor folicular y en el medio de maduración completo.

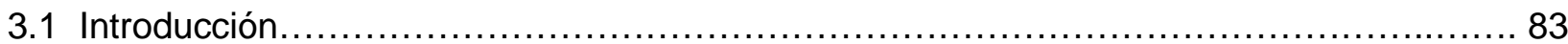

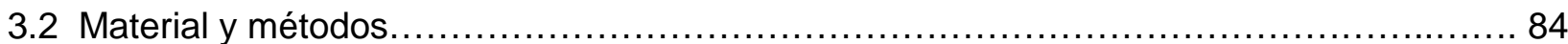

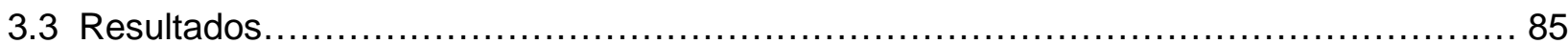

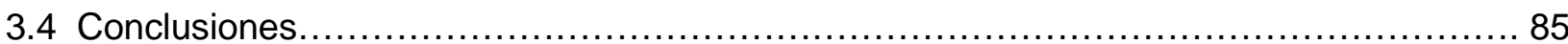

\section{Capítulo 2}

Efecto de distintas concentraciones de zinc sobre la maduración de los ovocitos bovinos

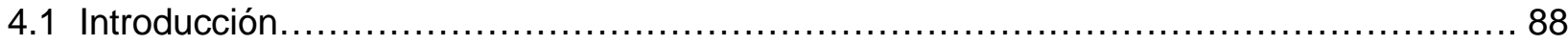

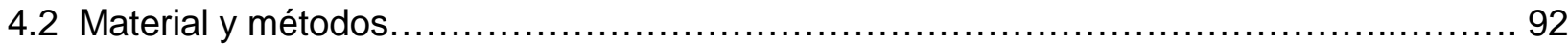

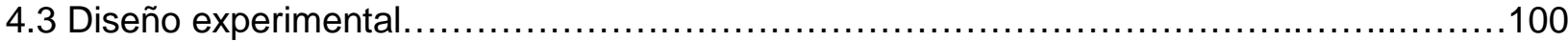

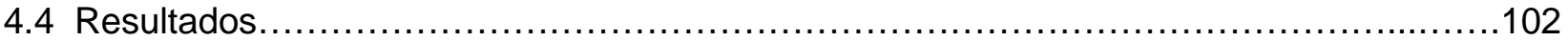

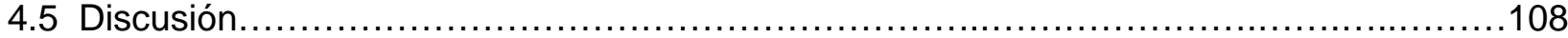

\section{Capítulo 3}

Efecto de distintas concentraciones de zinc sobre la capacidad de desarrollo posterior hasta el estadio preimplantacional de blastocisto

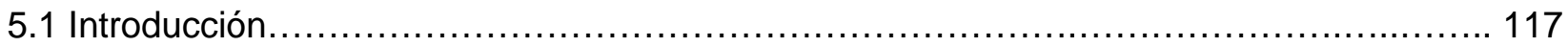

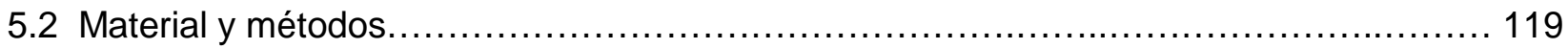

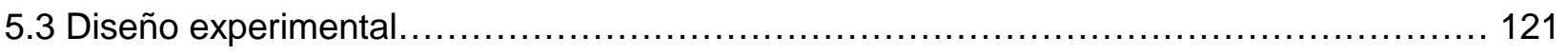

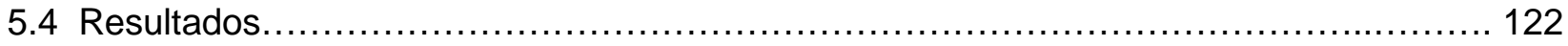

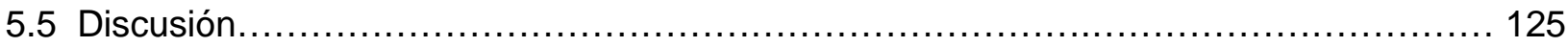




\section{Capítulo 4}

Rol de las células del cúmulus como puente metabólico entre el medio externo y el ovocito, con diferentes niveles en el aporte de zinc durante la MIV

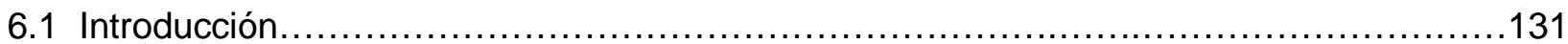

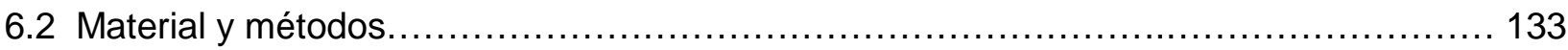

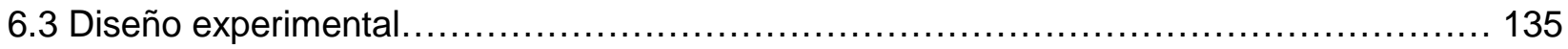

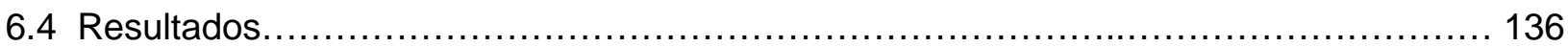

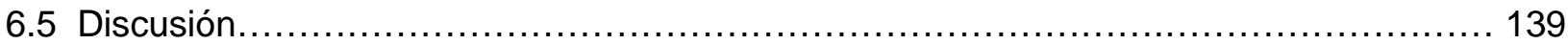

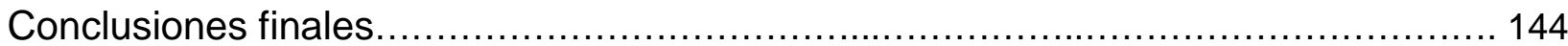

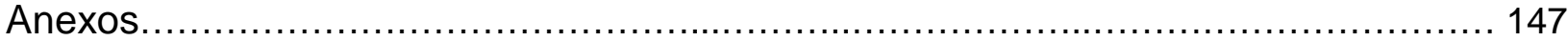

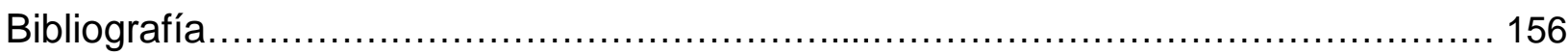




\section{Abreviaturas}

AH: ácido hialurónico

CC: células del cúmulus

CGP: células germinales primordiales

CIV: cultivo in vitro

COC: complejo ovocito-cúmulus

Cu/Zn-SOD: cobre/ zinc superóxido dismutasa

DO + CC: ovocito desnudo cocultivado con células del cúmulus

DO: ovocito desnudo

FIV: fertilización in vitro

FSH: hormona folículo estimulante

GSH: glutatión

LF: licor folicular

LH: hormona luteinizante

MII: metafase II

mg: miligramos

MIV: maduración in vitro 
ml: mililitros

nmol: nanomol

PBS: sulución buffer de fosfato

PIV: producción in vitro de embriones

pmol: picomol

PNM: pronúcleo masculino

PVP: polivinilpirrolidona

ROS: especies reactivas del oxígeno

SFB: suero fetal bovino

SOD: superóxido dismutasa

VG: vesícula germinal

Zn: zinc 


\section{EFECTO DEL ZINC SOBRE LA MADURACIÓN DE LOS OVOCITOS DE BOVINO Y SU IMPACTO SOBRE LA CAPACIDAD DE DESARROLLO EMBRIONARIO POSTERIOR}

Palabras claves: ovocito bovino, zinc, maduración in vitro, blastocisto

\section{Resumen}

EL presente trabajo de tesis consistió en evaluar el efecto del zinc ( $Z n)$ durante la maduración de los ovocitos de bovino sobre la capacidad de desarrollo embrionario posterior. Para tal fin, se han establecido los siguientes objetivos: 1) estudiar el efecto de distintas concentraciones de Zn sobre la maduración del ovocito bovino; 2) evaluar el efecto de distintas concentraciones de Zn durante la maduración in vitro (MIV) sobre la capacidad de desarrollo posterior hasta el estadio de blastocisto y 3) determinar el rol de las células del cúmulus como puente metabólico entre el medio externo y el ovocito. Para ello, se utilizó como modelo experimental, la técnica de Producción in vitro (PIV) de embriones bovinos que comprende tres etapas: MIV, Fertilización in vitro y Cultivo in vitro de embriones hasta el estadio de blastocisto. La PIV se realizó con ovocitos obtenidos a partir de ovarios bovinos de frigorífico. Los resultados mostraron que: 1) la suplementación con Zn no modificó la concentración intracelular de GSH/GSSG en ovocitos y células del cúmulus excepto cuando se utilizó una concentración de $0,7 \mu \mathrm{g} / \mathrm{ml} \mathrm{Zn,} \mathrm{2)} \mathrm{disminuye} \mathrm{la} \mathrm{tasa} \mathrm{de} \mathrm{apoptosis} \mathrm{y} \mathrm{el} \mathrm{daño} \mathrm{en} \mathrm{el} \mathrm{ADN} \mathrm{en} \mathrm{dichas} \mathrm{células} \mathrm{y} \mathrm{3)}$ 
aumenta la actividad SOD en los complejos ovocito-cúmulus. Además, 4) el agregado de Zn incrementó la tasa de blastocistos y 5) mejoró la calidad de los embriones. La tasa de blastocistos aumentó independientemente de la presencia de CC durante la MIV. En consecuencia, todas las evidencias obtenidas sugerirían que el Zn actuaría como un factor importante durante la maduración del ovocito bovino favoreciendo el desarrollo embrionario temprano. Estas evidencias sugerirían además, la posible existencia de transportadores de Zn en el ovocito bovino. 


\section{EFFECT OF ZINC ON CATTLE OOCYTES MATURATION AND ITS IMPACT ON SUBSEQUENT EMBRYO DEVELOPMENT}

Key words: bovine oocyte, zinc, in vitro maturation, blastocyst

\section{Summary}

This study evaluated the effect of zinc ( $\mathrm{Zn}$ ) during bovine oocyte maturation on preimplantational embryo development. For this purpose, we have established the following objectives: 1) Effect of different Zn concentrations on in vitro maturation (IVM) of bovine oocytes; 2) Effect of different Zn concentrations during IVM of bovine oocytes on subsequent embryo development to the blastocyst stage, and 3) Role of cumulus cells (CC) as metabolic bridge between the external medium and the oocyte. For this end, bovine in vitro embryo production (IVP) was used as experimental model. The IVP technique consists of three steps: IVM, in vitro fertilization and in vitro culture of embryos until blastocyst stage. The IVP was performed using bovine oocytes obtained from slaughterhouse ovaries. The results obtained here showed that: 1) The addition of Zn to IVM medium did not affect intracellular GSH-GSSG content in oocytes and CC with the exception of $0,7 \mu \mathrm{g} / \mathrm{ml} \mathrm{Zn;} \mathrm{2)} \mathrm{The} \mathrm{rates} \mathrm{of} \mathrm{apoptosis} \mathrm{and} \mathrm{DNA} \mathrm{damage,} \mathrm{in} \mathrm{both}$ oocytes and CC, were reduced when Zn was added to IVM medium; 3) SOD activity was higher in cumulus-oocyte complexes matured with the addition of Zn to IVM medium; 4) the addition of 
$\mathrm{Zn}$ in IVM medium improved the blastocyst rate and embryo quality; 5) the percentage of blastocysts was enhanced regardless of the presence of CC during IVM. Consequently, all evidences obtained suggest that $\mathrm{Zn}$ acts as an important factor during bovine oocyte maturation promoting early embryo development. Besides, these evidences suggest that $\mathrm{Zn}$ transporters might exist in the oocytes. 


\section{Introducción general}

\subsection{Aspectos Históricos}

Desde principios de siglo $\mathrm{XX}$, se han realizado diversos estudios para comprender el proceso de la fecundación en mamíferos. Estos estudios contribuyeron en gran medida al conocimiento de la biología de la reproducción. Para llevar a cabo este tipo de investigaciones fue necesario desarrollar condiciones in vitro, similares a aquellas encontradas en el oviducto in vivo, que permitieran mantener al óvulo y al espermatozoide en estado funcional.

Los trabajos que estimularon el desarrollo de modelos in vitro fueron realizados por el grupo de Pincus durante la década del 30 (Pincus y Enzmann, 1935; Pincus y Saunders, 1939). En estos trabajos se mezclaron espermatozoides y ovocitos maduros de conejo en un medio de cultivo que permitió su viabilidad in vitro. Los ovocitos recién fecundados fueron luego transferidos a oviductos de conejas a las cuales se les había inducido la ovulación, lográndose finalmente el nacimiento de las crías. A pesar de este primer logro en mamíferos, a lo largo de la década del 40, muchos de los conocimientos sobre fecundación se basaron en estudios realizados en el erizo de mar. Fue recién en la década del 50 que los estudios sobre la fisiología de la reproducción en mamíferos tomaron un auge inesperado debido al éxito obtenido en la fecundación in vitro (FIV) en conejo, ratón y hámster y al descubrimiento del fenómeno de 
capacitación como proceso fundamental para que el espermatozoide adquiera capacidad fecundante (Austin, 1951; Chang, 1951; Chang, 1968; Chang y col., 1977).

Por otro lado, uno de los estudios más destacados fue realizado por Sreenan (1970) en bovinos, quien utilizó semen de toro preincubado en un medio con -amilasa con el propósito de intentar fecundar in vitro a ovocitos madurados in vitro. Sin embargo, fueron Iritani y Niwa (1977) en Japón, quienes lograron finalmente la fecundación in vitro de ovocitos bovinos madurados en cultivo.

Si bien hasta ese momento se habían realizado grandes avances en el modelo bovino in vitro, era necesario evaluar la eficacia del sistema con el nacimiento de crías. Fue por esta razón, que unos años más tarde el trabajo de Brackett y colaboradores (1982), provocó un gran impacto ya que informaba del nacimiento en EEUU del primer ternero producido mediante fecundación in vitro de ovocitos ovulados y recuperados del oviducto. Casi simultáneamente Lambert y colaboradores (1983), en Canadá, empleando técnicas de laparoscopía para obtener ovocitos directamente del ovario de la hembra en un momento próximo a la ovulación, consiguieron por fecundación in vitro dos nuevos nacimientos. Unos años más tarde, Hanada y colaboradores (1986) informaron nacimientos a partir de ovocitos madurados y fecundados in vitro. Es importante destacar, que este estudio aportó gran cantidad de información debido a que durante el mismo se implementaron una serie de técnicas: los embriones obtenidos se transfirieron por primera vez en el estadio de blastocisto, luego de ser cultivados en el útero de conejas, y fueron congelados y descongelados antes de ser transferidos a la hembra receptora. Un año más tarde, Lu y colaboradores (1987) obtuvieron en Dublin terneros desarrollados a partir de un procesamiento in vitro completo que incluyó las etapas de maduración, fecundación, y cultivo de embriones in vitro, proceso que se denominó producción in vitro de embriones (PIV). 
Este progreso alcanzado en el manejo reproductivo in vitro en bovinos también tuvo repercusión en ovinos, porcinos, equinos, caprinos, búfalos y ciervos, teniendo gran auge las investigaciones orientadas hacia las especies en vías de extinción. La mayoría de los trabajos realizados con embriones de rumiantes fueron compilados por Trounson (1992). Entre ellos podemos mencionar los estudios realizados en Francia con ovinos y caprinos por Crozet y colaboradores (1987) utilizando diversas técnicas de capacitación, con la obtención de nacimientos luego de la transferencia de cigotos obtenidas in vitro, así como los estudios realizado por Slavik y Fulka $(1991,1992)$ en Checoslovaquia que lograron nacimientos a partir de embriones obtenidos in vitro.

En porcinos, Cheng y colaboradores (1986) consiguieron nacimientos a partir de ovocitos madurados in vivo. Sin embargo, el primer informe de desarrollo de embriones madurados y fecundados in vitro proviene del trabajo publicado por Mattioli y colaboradores (1989). Si bien en porcinos se han publicado muchos trabajos relacionados con el proceso de la maduración, fecundación y cultivo in vitro de embriones, queda mucho por realizar para solucionar los altos niveles de polispermia que presentan (Yoshida y col., 1992 a; 1993; Zheng y Sirard, 1992; Coy y col., 1993; Clark y col., 2005; Somfai y col., 2008; Gil y col., 2010).

Palmer y colaboradores $(1990,1991)$ en Nouzilly (Francia) lograron obtener el primer potrillo luego de una FIV empleando ovocitos madurados in vivo. Hasta el presente, la fecundación in vitro se ha mantenido como una técnica de muy bajo rendimiento en esta especie, sólo se han informado el nacimiento de dos potrillos a partir del empleo de la misma (McPartlin y col., 2009). En equinos, las tasas de fecundación obtenidas por FIV son muy variables (0 a 60 \%) (Mugnier y Col., 2009) y más bajas que las tasas de FIV observadas en el resto de las especies domésticas: porcinos: 40 a 82,2 \% (Abeydeera y Day, 1997; Funahashi y Day, 1997; Wang y col., 1997; Nagai y col., 2006; Somfai y col., 2008); bovinos: 72 a 87 \% 
(Hashimoto, 2009; Lopes y col., 2010); caprinos: 46 a 79,4 \% (Crozet y Col., 1995; KatskaKsiazkiewicz y Col., 2004) y ovinos: 72,5 a 84,3 \% (Wan y Col., 2009). Esta variabilidad está relacionada a la incompleta maduración in vitro del ovocito (Li y Col., 2001; Hashimoto, 2009), a la ineficiente capacitación espermática (Alm y Col., 2001; Petrunkina y col., 2007) y/o a cambios en la zona pelúcida (Dell’Aquila y Col., 1999; Hinrichs y Col., 2002; Rienzi y col., 2011). En 1997, Dell'Aquilla y colaboradores (1997) mejoraron las tasas de FIV de ovocitos equinos madurados in vitro, utilizando la inyección intracitoplasmática de un espermatozoide (ICSI). Desde entonces, la técnica de ICSI ha sido utilizada como alternativa a la FIV convencional, ya que elimina los problemas relacionados a la unión espermatozoide-ovocito y a la penetración espermática (Ben-Yosef y Shalgi, 1998; Goldberg y col., 2007).

En la década del 90, se le prestó especial atención a las funciones que cumplen los aminoácidos (Gardner y col., 1994; Hill y col., 1997), las glicoproteínas (Hunter, 1994), los protectores contra el estrés oxidativo (Yoshida, 1993) y los glicosaminoglicanos (GAG) presentes en los fluidos folicular, oviductal y uterino (Sato y col., 1990; Edelstam y col., 1991; Carolan y col., 1995)

Todos estos estudios fisiológicos y metabólicos realizados en ovocitos, espermatozoides y embriones de mamífero en relación con el microambiente que los rodea, han permitido ampliar los conocimientos en el campo de la biología de la reproducción. En los últimos años, las investigaciones se han centrado en la regulación ejercida por diversos factores ovocitarios sobre las funciones de las células del cúmulus (Gilchrist y col. 2008), el rol que desempeñan distintos factores de crecimiento durante la maduración in vitro del ovocito (Chen y col., 2008; Shabankareh y Zandi, 2010) y en el estudio de las vías metabólicas involucradas en dicho proceso (Sutton-McDowall y col., 2010). También han sido objeto de estudio, la dinámica de los eventos relacionada con los microfilamentos durante la maduración del ovocito y la fecundación 
(Sun y Schatten, 2006) y las funciones de las mitocondrias en ovocitos y embriones preimplantacionales (Wang y col., 2009).

La técnica denominada Ovum Pick-up (OPU), descripta por primera vez en el bovino por Pieterse y col. (1988) permite obtener ovocitos de una donante por aspiración folicular transvaginal guiada por ecografía (Mapletoft y Hasler, 2005). El uso de OPU, ha permitido incrementar la producción de embriones de una donante determinada mediante la maduración y fecundación in vitro de ovocitos (Brogliatti y Adams, 1996; Bols, 2005). Esta técnica, se utilizó para producir embriones a partir de ovocitos de terneras, acortando así el intervalo generacional, o de ovocitos de hembras gestantes (Brogliatti y Adams, 1996; Taneja y col, 2000; Merton y col., 2009). Wilson y colaboradores (2005) plantean la utilización de semen sexado para la fecundación in vitro de ovocitos obtenidos por OPU para la producción de vaquillonas de reemplazo de razas lecheras, así como en programas de mejoramiento genético. En el año 2005, los embriones producidos a partir de ovocitos obtenidos por OPU representaron el $30 \%$ del total de embriones transferidos en el mundo, siendo Brasil el responsable del 50\% de esta producción (Thibier, 2006).

\subsection{Ovogénesis}

\subsubsection{Introducción}

La ovogénesis es el proceso por el cual se forman las gametas femeninas. Estas gametas se denominan ovocitos y son los encargados de aportar, entre otras cosas, el complemento haploide de cromosomas de la hembra que, junto con el del espermatozoide, darán origen a un nuevo individuo. En los mamíferos, la ovogénesis comienza relativamente temprano durante el desarrollo del feto y termina meses o años más tarde en el momento de la madurez sexual del 
adulto (Halfter y col., 1996; Abrieu y col., 2001; van den Hurk y Zhao, 2005; Liu y col., 2006; Aerts y Bols, 2010). La ovogénesis se inicia con la formación de las células germinales primordiales (CGP) que sufren una serie de cambios para transformarse en ovocitos primarios (ambos estadios en el feto) hasta llegar al estadio de ovocito secundario en el animal adulto.

\subsubsection{Formación de ovocitos}

El proceso de formación del ovocito se inicia con la generación de las CGP; su migración a las gónadas, la colonización de las gónadas por las CGP, su diferenciación a ovogonias, la proliferación de las ovogonias, la iniciación de la meiosis y por último el arresto meiótico en estadio de diplotene de la profase I (van den Hurk y Zhao, 2005). Los ovocitos se forman a partir de un pequeño número de CGP de origen extragonadal (Clark y Eddy, 1975; Buccione y col., 1990; Aerts y Bols, 2010). La aparición de estas células durante el desarrollo embrionario, previamente a la formación de los somitos, indica el comienzo de la ovogénesis. Varios estudios sugieren que los rudimentos embrionarios del alantoides y la parte caudal de la línea primitiva podrían considerarse como lugares de formación de las CGP. Hahnel y Eddy (1986), localizaron a las CGP en el epiblasto del embrión de ratón durante el proceso de gastrulación. Posteriormente, Ginsburg y colaboradores (1990), localizaron a estas células durante la gastrulación de embriones de ratón de 7 días de edad. Las CGP aparecen ubicadas en el mesodermo extraembrionario, estas son ocho células grandes, fosfatasa alcalina positivas, con núcleos prominentes, estructuras subcelulares específicas y capacidad migratoria. Hasta ahora no ha quedado del todo claro por medio de que mecanismo se desplazan estas células, si lo hacen mediante movimientos ameboides, extendiendo filopodios sobre las células subyacentes, o avanzan por movimientos de crecimiento del tejido adyacente (Freeman, 2003). Las CGP migran primero hacia el mesodermo por la línea primitiva y luego hacia el endodermo siguiendo 
el camino del alantoides. Hacia los 7,5 días de desarrollo, las CGP se ubican en la pared endodérmica del saco vitelino, donde se dividen en dos grupos, que migran en dirección caudal desde el saco vitelino hacia el intestino posterior recientemente formado y, desde allí, hacia el mesenterio dorsal para alcanzar finalmente las gónadas derecha e izquierda a los 11 días de desarrollo. Durante la migración, las células han proliferado de una población de 10 a 100 células a una de 2500 a 5000 células. Esta nueva población celular se encuentra asociada con las células sobre las que se desplaza siendo capaz de penetrar monocapas y migrar a través de ellas (Stott y Wylie, 1986). La totalidad de las CGP llega a las gónadas a los 12 días de desarrollo. Aún no se conoce completamente el mecanismo por el cual reconocen la ruta que deben seguir, pero se cree que podrían ser guiadas a través del contacto con un sustrato a lo largo de todo su camino. Este reconocimiento estaría mediado por la unión del receptor c-kit que se expresa en la superficie de las CGP y su ligando Ligando Kit (LK) o Stem Cell Factor (SCF o Factor Células Madre) que se expresa en las células somáticas a lo largo de todo el trayecto migratorio (van den Hurk y Zhao, 2005). Componentes de la matriz extracelular como por ej. la fibronectina, podrían también contribuir a la formación de una ruta migratoria y servirían para estimular el traslado de las CGP migrantes (Fujimoto, 1985; Halfter y col., 1996). Además, se cree que sustancias producidas por la cresta gonadal conducen por quimiotaxis a las CGP hacia las gónadas y estimulan su actividad mitótica (Godin y col., 1990; van den Hurk y Zhao, 2005). El SCF estimula la proliferación de las CGP, de los melanoblastos de la cresta neural y de las células madre hemocitopoyéticas. Evidencias in vitro indican que el esbozo de las gónadas secreta una proteína difusible del tipo TGF- $\beta 1$ (factor de crecimiento transformante $\beta 1$ ), capaz de atraer a las CGP en su ruta hacia los ovarios primitivos (Godin y col., 1990; Godin y Wyle, 1991). Luego de alcanzar la superficie de las gónadas, las CGP migran hacia la corteza del ovario donde, junto con las células epiteliales, dan origen a los cordones sexuales corticales (van den Hurk y Zhao, 2005). Los componentes parenquimatosos del ovario derivan 
principalmente del epitelio célomico y del mesénquima dorsal, aunque se cree que el mesonefros también contribuye a la formación del soporte somático. En embriones de ratón de 13 días de desarrollo (52 - 60 pares de somitos) el ovario ya se encuentra diferenciado y las CGP han completado la migración hacia los cordones sexuales corticales. La expresión de moléculas de adhesión es fundamental para que las CGP colonicen las gónadas y formen los cordones sexuales corticales (Anderson y col., 2001). En el ovario, las divisiones mitóticas de las CGP dan origen a grupos de ovogonias que se encuentran conectadas entre ellas por medio de puentes citoplasmáticos intercelulares. Cuando la formación de estos grupos se completa, el ovario queda constituido por unas pocas células germinales individuales y numerosos sincitios de CGP. Estos grupos comienzan a separarse para formar los folículos individuales, en el segundo trimestre de gestación en el humano y después del nacimiento en el ratón (Tingen y col., 2009). El número total de ovogonias que tiene cada individuo ya está fijado antes de la madurez sexual y en algunos casos antes del nacimiento. En la mayoría de los mamíferos la proliferación de las ovogonias está restringida al período prenatal o a unos pocos días posteriores al nacimiento (Mauleon, 1967). Por ejemplo, mientras que en primates y rumiantes este proceso se lleva a cabo durante la vida fetal, en roedores y conejos se desarrolla durante el período neonatal temprano por lo que el ovario presenta luego del nacimiento, aproximadamente 8000 ovocitos detenidos en meiosis, que están rodeados por células foliculares (Hirshfield, 1991). Sin embargo, en los lémures la actividad mitótica de las células germinales continúa aún en el adulto (Drion y col., 1996).

Durante el preleptonema (período de la interfase que sigue a la última división mitótica de la ovogonia), el ADN se replica para iniciar la meiosis, siendo esta actividad la señal que indica que la ovogonia se ha transformado en ovocito primario. A los 12 días de la embriogénesis, unas pocas ovogonias (5\%) ya comienzan a trancitar el estadio de leptonema de la Profase I 
de la meiosis (Baker, 1972; 1982; Zuckerman y Baker, 1977; Byskov, 1982). El progreso de esta etapa no requiere de una estimulación de tipo endocrino ya que, se ha observado en estudios in vitro que la profase meiótica continúa en ausencia de un ambiente gonadal (Urner y col., 1983).

En el embrión de 14 días de edad (61 - 62 pares de somitos) la población de células germinales está formada por partes iguales de ovogonias y ovocitos primarios, mientras que hacia el día 17 de la embriogénesis (65 pares de somitos), el ovario contiene solamente ovocitos primarios en varios estadios de la primera profase meiótica (Baker y Franchi, 1967a, 1967b; Habibi y Franchi, 1978; Bachvarova y col., 1982; Speed, 1982). Los ovocitos primarios necesitan de 3 a 6 horas para completar el leptonema y, entre 12 y 40 horas, para completar el zigonema. Durante el zigonema los cromosomas homológos forman pares y se produce la sinapsis, dando como resultado cromosomas bivalentes compuestos por cuatro cromátidas. En el embrión de 18 días la mayoría de los ovocitos primarios se encuentran en el estadio de paquinema de la profase correspondiente a la primera división meiótica. Durante este estadio que dura aproximadamente 60 horas, se produce el entrecruzamiento (crossing-over) y recombinación del material genético. Por lo tanto, la progresión de la profase desde el estadio de leptonema hasta paquinema dura aproximadamente 4 días. En el día 19 de la embriogénesis aparecen los primeros ovocitos primarios en diplonema con los cromosomas exhibiendo quiasmas como resultado del crossing-over. La profase se desarrolla hasta diplonema con síntesis de ARNr, ARNt y ARNm. El proceso de síntesis es muy activo y difícil de detectar en etapas posteriores luego de la ruptura de la vesícula germinal (envoltura nuclear) (Wassarman y Letourneau, 1976). Los ovocitos primarios quedarán detenidos en diplonema tardío o difuso (también llamado estadio de diacinesis) hasta la atresia folicular o hasta que el folículo complete su crecimiento en respuesta al pico de hormona luteinizante (LH) que induce la reanudación de la meiosis convirtiendo al ovocito primario en una gameta haploide (van den Hurk y Zhao, 
2005). Una de las doctrinas básicas de la biología indica que la mayoría de las hembras de mamífero pierden la capacidad de renovación de las células germinales durante la vida fetal, quedando fijada la reserva de ovocitos primarios al momento del nacimiento. Sin embargo, estudios realizados en primates adultos (David, 1974; Bukovsky y col., 2004) y en ratones (Johnson y col., 2004) demostraron que en estos casos, los ovarios poseen células germinales mitóticamente activas que son capaces de formar ovocitos y folículos. Bukovsky y col. (2004) sugieren que células progenitoras mesenquimáticas presentes en la túnica albugínea de ovarios de mujeres adultas, podrían diferenciarse en los componentes que forman los folículos primordiales (células germinales y de la granulosa primitiva) durante el período reproductivo.

\subsubsection{Formación de folículos primordiales}

Coincidentemente con la iniciación de la meiosis, surgen los folículos primordiales que se componen de un ovocito rodeado por una capa de células somáticas escamosas planas (células pregranulosas). En la mayoría de las especies las células pregranulosas tendrían un origen dual a partir de células epiteliales de la superficie, que migran hacia el interior del ovario y de células derivadas del mesonefros que ascienden a través de éste (van den Hurk y col., 1995; Garrett y Guthrie, 1999; Sawyer y col., 2002). Durante el inicio de la actividad meiótica gran parte de los ovocitos degeneran provocando una disminución en el número de folículos primordiales presentes en el ovario al momento del nacimiento. Esta pérdida puede alcanzar cerca del $60 \%$ en porcinos, $80 \%$ en roedores, $90 \%$ en humanos y aún más en rumiantes (McNatty y col., 1995; Guthrie y Garrett, 2001; van den Hurk y Zhao, 2005). El pool de folículos primordiales se caracteriza por mantener una relativa quiescencia hasta poco antes de la pubertad, momento en que el ovario comienza a ser receptivo a las hormonas gonadotróficas (Eichenlaub-Ritter y Peschke, 2002). 


\subsubsection{Formación de folículos primarios}

Los folículos primordiales se mantienen quiescentes hasta que son reclutados dentro de una población en crecimiento. Cada día, un grupo de folículos primordiales son reclutados y transformados en folículos primarios. Los folículos primordiales se convierten en primarios tras la hipertrofia de las células planas que rodean al ovocito y que se transforman en células cúbicas. A partir de este momento el folículo comienza a crecer en un proceso continuo que está regulado por el ovario y en el cual, el ovocito y las células foliculares que lo rodean crecen coordinadamente, progresando a través de una serie de estadios morfológicos definidos que culminan en la ovulación de un ovocito maduro o en la atresia folicular (Pedersen y Peters, 1968; van den Hurk y Zhao, 2005; Liu y col., 2006; Moniruzzaman y Miyano, 2010) (Figura 1). El número de folículos primordiales que comienzan a crecer en cada ciclo es probablemente consecuencia de un balance entre factores estimuladores e inhibidores de origen sistémico y/o local (van den Hurk y Zhao, 2005; Tingen y col., 2009; Moniruzzaman y Miyano, 2010) e independiente de la acción directa de la hormona foliculoestimulante (FSH) (Meduri y col., 2002).

\subsubsection{Crecimiento del ovocito y formación de folículos multilaminares} (secundarios)

Durante la fase de crecimiento el ovocito permanece detenido en diplonema de la primera profase meiótica e incrementa su volumen hasta 500 veces, convirtiéndose en una de las células más grandes del organismo. La cantidad de citoplasma aumenta por acumulación de sustancias de reserva produciéndose un incremento en la síntesis de ARN. Además, aumenta el número de mitocondrias, se forman los gránulos corticales que contienen mucopolisacáridos 
y enzimas proteolíticas que se ubican por debajo de la membrana plasmática, se forman microvellosidades en la membrana citoplasmática y se observa la zona pelúcida. Esta última, está constituida por glicoproteínas como la ZPI que mantiene la esfericidad del ovocito y, la ZPII y ZPIII que intervienen en la unión con el espermatozoide (Wassarman, 1990). En contraste con ZPI y ZPIII la expresión de ZPII ocurre en el folículo primordial (van den Hurk y Zhao, 2005). Las proteínas de la zona pelúcida son sintetizadas por el ovocito (Wassarman y Mortillo, 1991). La zona pelúcida en humanos consta de cuatro glucoroteínas (ZPI a ZPIV). Las ZPII y ZPIII se combinan para formar unidades básicas que se polimerizan en largos filamentos. Estos filamentos se unen de manera periódica mediante puentes cruzados formados por moléculas de ZPI y ZPIV (Goudet y col., 2008).

El crecimiento del ovocito en el ratón se completa en un corto período de tiempo (2 o 3 semanas) mientras que en otras especies puede llevar meses o años (Pincus, 1936; Abrieu y col., 2001; Moniruzzaman y Miyano, 2010). La capa de células foliculares cúbicas del folículo primario se estratifica por una serie de divisiones mitóticas pasando a constituir las células de la granulosa. Alrededor de éstas se desarrolla una capa de células que forman la teca a partir de células del estroma intersticial. De esta manera queda constituido el folículo multilaminar (también llamado secundario o preantral) (van den Hurk y Zhao, 2005; Aerts y Bols, 2010; Young y McNeilly, 2010). Richards (1979) demostró que tanto los estrógenos como la FSH estimulan la proliferación de las células de la granulosa ejerciendo un efecto mitogénico sobre las mismas. Estas células, además de comunicarse entre ellas forman uniones nexo (gap) con el oolema del ovocito (Anderson y Albertini, 1976; Heikinheimo y Gibbons, 1998). Estas uniones están formadas por proteínas conexinas como la conexina 37 la cual es expresada por el ovocito durante todo los estadios de la foliculogénesis (McGhee y Hsueh, 2000; Amleh y Dean, 2002). Este tipo de uniones se encuentran en muchos sistemas biológicos y actúan como 
mediadores de la comunicación intercelular permitiendo el pasaje de pequeñas moléculas que influyen sobre las células vecinas (Gilula y col., 1978; Lawrance y col., 1978), como por ejemplo: nutrientes, precursores metabólicos (como aminoácidos y nucléotidos) y moléculas de señalización como hormonas y factores de crecimiento (van den Hurk y Zhao, 2005).

Figura 1. Fases de crecimiento del folículo (Adaptado de van den Hurk y Zhao, 2005).

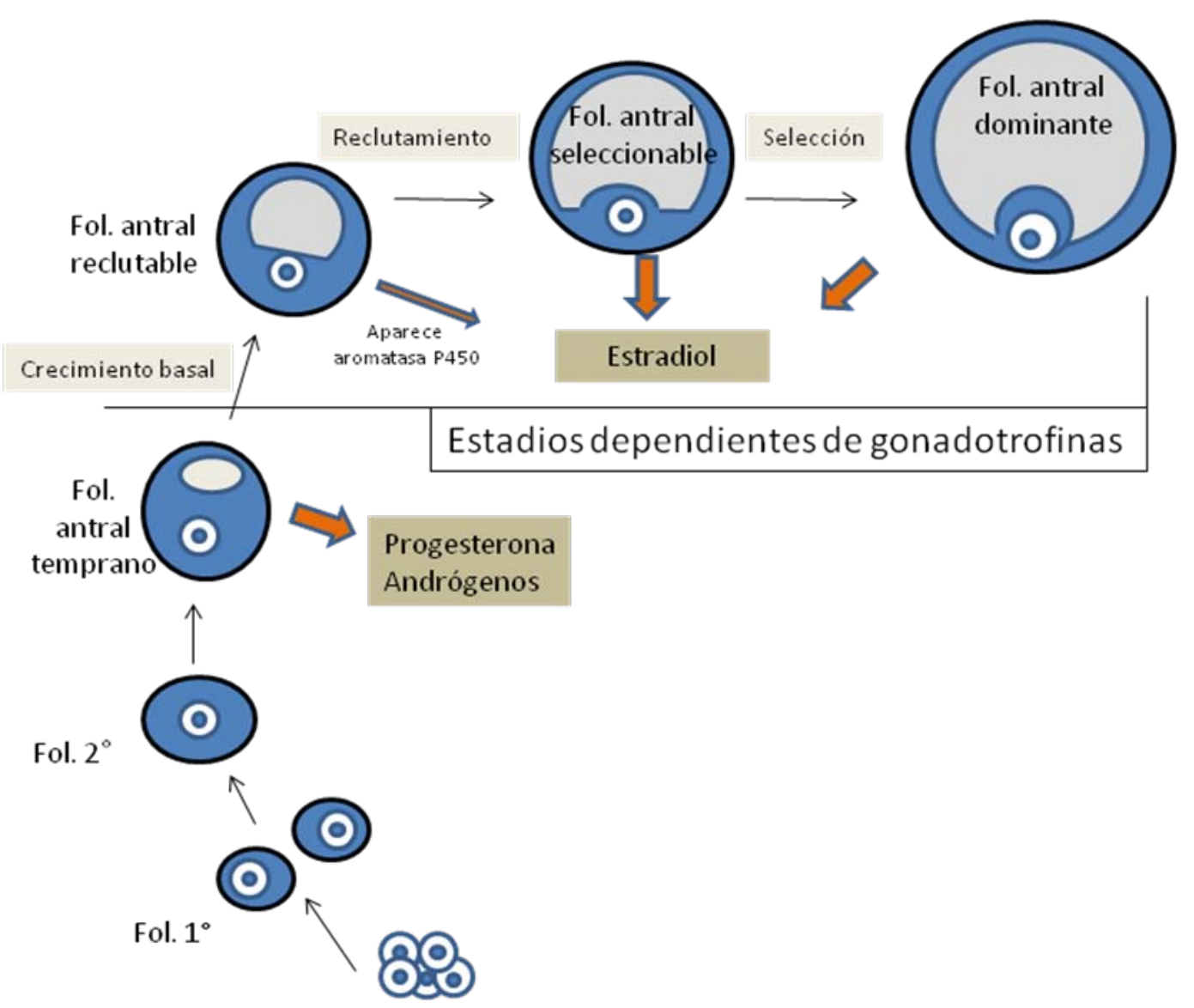

Fol. primordiales 
Aunque los folículos multilaminares son sensibles a hormonas gonadotróficas, pueden desarrollar hacia el próximo estadio (folículo antral) en presencia de una mínima circulación de FSH o con receptores defectuosos para FSH (McGhee y Hsueh, 2000). La LH juega un rol preponderante en el desarrollo del folículo multilaminar. Los receptores para LH presentes en la teca de los folículos multilaminares tempranos de ratón estimulan la biosíntesis de andrógenos tecales los que a su vez promueven la formación de receptores para FSH en células de la granulosa, amplificando de este modo la acción de la FSH en estos folículos (van den Hurk y col., 1999).

\subsubsection{Crecimiento del ovocito y formación de folículos antrales}

Estudios realizados años atrás en mamíferos euterios han establecido claramente un patrón bifásico en el crecimiento del ovocito y del folículo. Durante la primera fase el crecimiento de ambos es lineal y tiene una correlación positiva. En el momento en que el ovocito alcanza su tamaño máximo, justo antes de la formación de la cavidad antral, comienza la segunda fase en la cual aumenta la actividad mitótica de las células de la granulosa y de las células de la teca, mientras que la acumulación de liquido folicular se transforma en el evento más importante. Esta misma relación se ha observado en monotremas y marsupiales (Aerts y Bols, 2010).

El fluido antral (o folicular) es una fuente importante de moléculas reguladoras y moduladoras derivadas de la sangre, como por ej.: gonadotrofinas, esteroides, factores de crecimiento, enzimas, proteoglicanos y lipoproteínas (van den Hurk y Zhao, 2005). Durante el desarrollo folicular, la producción de fluido antral se intensifica por un aumento en la vascularización y permeabilidad de los vasos sanguíneos del folículo. La señal que dispara la formación del antro permanece hasta el momento poco clara. Estudios in vitro realizados en roedores muestran como posibles candidatos a la FSH (Hartshorne, 1997; Mao y col., 2002), 
LH (Cortvrindt, 1998), activina (Zhao y col., 2001) y al Ligando K (Driancourt y col., 2000). En su desarrollo, el folículo antral atraviesa cuatro etapas o fases: fase de crecimiento basal, de reclutamiento, de selección y de dominancia (Webb y col., 1999; Driancourt, 2001; Fortune y col., 2001; Findlay y col., 2002). Si bien, los folículos antrales tempranos presentan ARNm para receptores de $\mathrm{FSH}$, estos folículos son relativamente independientes de las gonadotrofinas durante el período de crecimiento inicial. Estos folículos aumentan su tamaño en presencia de muy bajas concentraciones de FSH y LH e incluso lo hacen en ausencia de las mismas (van den Hurk y Zhao, 2005). Cuando los folículos antrales alcanzan un tamaño de aproximadamente 0,2 $\mathrm{mm}$ en la hembra de ratón, $1 \mathrm{~mm}$ en cerda, $2 \mathrm{~mm}$ en oveja, $4 \mathrm{~mm}$ en la vaca y $10 \mathrm{~mm}$ en la yegua se vuelven dependientes de gonadotrofinas y son reclutados para continuar su crecimiento (Driancourt, 2001). El número de folículos reclutados varía entre las especies, de 5 a 10 en vaca, de 1 a 4 en yeguas o más de 50 en el caso de las cerdas. El reclutamiento y la selección de folículos antrales ocurren en forma de ondas y en número de 2 a 3 (vaca), 3 a 4 (oveja), 4 a 5 (cabra) y 1 a 2 (yegua) ondas por ciclo. En la oveja al igual que la vaca el tamaño del folículo reclutado se corresponde con el tamaño en el que la aromatasa P450, responsable del pasaje de andrógenos a estrógenos, se vuelve detectable en la granulosa (Webb y col., 1999; Driancourt, 2001; Fortune y col., 2001). Al comienzo de la madurez sexual una señal hormonal selecciona un grupo de folículos que continúan su crecimiento. En esta selección intervienen las hormonas FSH, LH y los estrógenos. La FSH estimula el crecimiento de los folículos por proliferación de las células foliculares. Cuando los folículos superan los $4 \mathrm{~mm}$ en oveja, 5 a $6 \mathrm{~mm}$ en cerda, $8 \mathrm{~mm}$ en vacas o $25 \mathrm{~mm}$ en las yeguas comienzan a desarrollar receptores de LH en células de la granulosa (Driancourt, 2001) y reciben el nombre de dominantes. Estos folículos sometidos a la acción de la $\mathrm{LH}$ e independientemente que la concentración de FSH disminuya, crecen rápidamente en pocos días y se vuelven más grandes que el resto. En los folículos dominantes, el ovocito se 
encuentra rodeado por células de la granulosa conocidas como células del cúmulus (CC) formando un complejo muy compacto llamado complejo ovocito-cúmulus (COC). Este complejo es una "península" embebida en liquido folicular y conectado con las células de la granulosa murales que rodean el antro folicular (Figura 2).

Figura 2. Folículo antral de bovino con el oocito primario fuertemente adherido a las células de la granulosa (Gordon 1996).

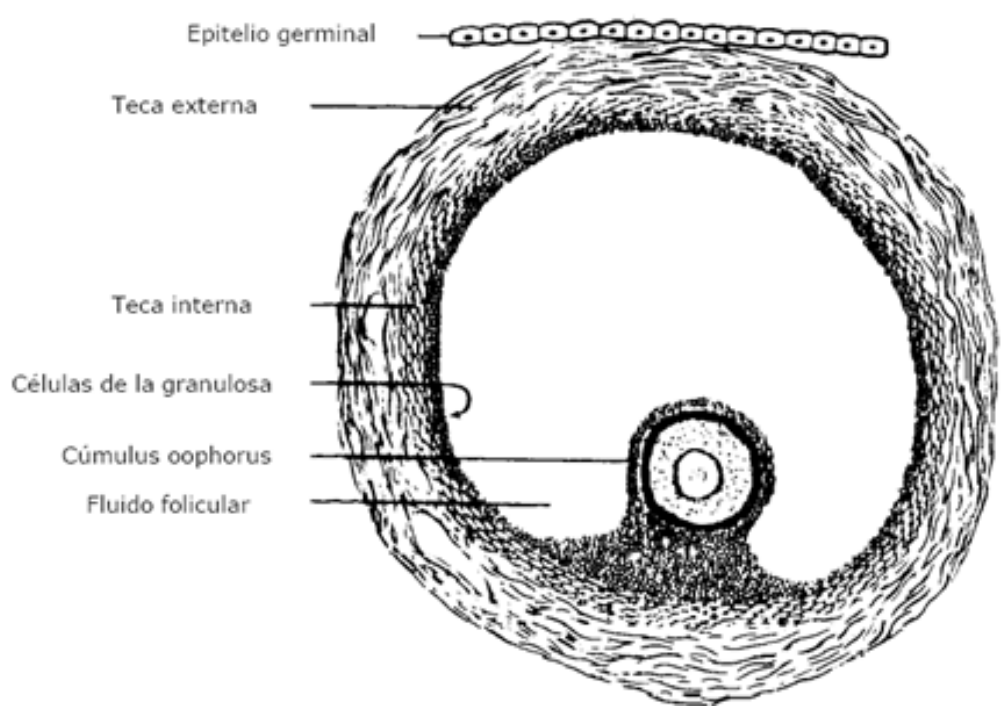

La dominancia folicular se encuentra reforzada por al menos dos factores locales: el IGF-I (Factor de crecimiento similar a la insulina tipo uno) que estimula la formación de receptores LH (Chase y col., 1998) y el VEGF (Factor de crecimiento del endotelio vascular), un potente promotor de la angiogénesis derivado de la teca, cuya producción se encuentra estimulada por la LH (Garrido y col., 1993). La LH que llega a las células foliculares provoca la producción de altos niveles de estrógenos, que mediante un mecanismo de retroalimentación negativa a nivel 
del eje hipotálamo-hipofisario, inhibe la producción de FSH, privando a los folículos menos desarrollados de la cantidad de hormona necesaria para completar el proceso de crecimiento (Zeleznik, 1981). Se cree que esta inhibición disminuye la actividad de la enzima aromatasa que es dependiente de la FSH. Esta falta de estrógenos en los folículos inmaduros impide completar su desarrollo por lo que estarían destinados a morir (Zelenik, 1981).

En el momento en que las células foliculares que rodean al antro se estratifican para formar la granulosa, el estroma ovárico que está por fuera comienza a diferenciarse en células de la teca, que se apoyan sobre la membrana basal que separa ambas capas entre sí. La teca, por su parte, se diferencia en dos capas: la interna que es glandular y muy vascularizada y la externa, constituida por tejido conectivo y fibras musculares lisas, que es muy difícil de diferenciar del estroma que la rodea. Las células de la granulosa y las de la teca folicular actúan como un sincitio funcional debido a la presencia de uniones gap que las comunican entre sí, permitiendo la transmisión de las señales hormonales (Burghardt y Anderson, 1981; Fletcher y Greenan, 1985; Young y McNeilly, 2010).

Cuando se forma el antro, el ovocito finaliza su crecimiento y está en condiciones de reanudar la meiosis (Mattson y Albertini, 1990; Wickramasinghe y col., 1991). Las células de la granulosa presentan un gradiente en el número de receptores para $\mathrm{LH}$, siendo estos mucho más abundantes en las células próximas a la membrana basal que en las que están más alejadas de ella.

\subsubsection{Maduración del ovocito}

Durante el período comprendido entre el pico de LH y la ovulación, el ovocito sufre una serie de cambios en su núcleo y en su citoplasma, proceso al que se denomina maduración del ovocito. La maduración citoplasmática es necesaria para adquirir las condiciones que permiten 
bloquear la polispermia, para decondensar el núcleo del espermatozoide y para la formación del pronúcleo masculino luego de la fecundación. Durante este fenómeno se produce la redistribución de las organelas celulares, la migración de las mitocondrias a una posición perinuclear y la acumulación de los gránulos corticales a lo largo del oolema (van den Hurk y Zhao, 2005).

En los ratones sexualmente maduros, los ovocitos que han completado el crecimiento reinician la meiosis dentro de los folículos grafianos (folículos antrales maduros) y completan la división meiótica reduccional antes de la ovulación. En los ovocitos, la maduración nuclear progresa desde el estado de diplonema de la profase de la meiosis I (4 veces el complemento haploide de $A D N$ ) hasta la metafase de la segunda división meiótica (MII, 2 veces el complemento haploide de ADN). La meiosis in vivo se reinicia mediante un estimulo hormonal, pero, en condiciones in vitro es posible lograr que el proceso meiótico continúe, liberando los ovocitos por ruptura de la pared de los folículos ováricos dentro de un medio de cultivo adecuado (Wassarman y col., 1979; Tamarin, 1996; Kanitz y col., 2001). Los ovocitos permanecen en M II en el oviducto hasta ser estimulados para completar la meiosis en el momento de la fecundación o mediante una activación partenogenética. El progreso hasta el estadio de diplonema o diacinesis del ovocito hasta la metafase II se denomina maduración meiotica.

Este proceso se lleva a cabo en un corto período de tiempo [alrededor de 24 horas en vacas y ovejas, 36 horas en yegua y 44 horas en cerdas (van den Hurk y Zhao, 2005)] y se caracteriza por un fuerte incremento en la síntesis de proteínas en el período de ruptura de la vesícula germinal. Ya que no se puede realizar la transcripción de novo en este momento del ciclo, las proteínas deben ser sintetizadas a partir de un pool de ARNm latente. Por lo tanto, la 
regulación de la expresión génica en esta etapa del desarrollo está regulada a nivel de la traducción (Kanitz y col., 2001).

La maduración meiótica se caracteriza por la disolución de la membrana nuclear (vesícula germinal), la condensación de la cromatina formando cromosomas bivalentes distinguibles, la separación de los cromosomas homólogos, la emisión del primer cuerpo polar, y la detención en metafase II con los cromosomas alineados en el huso acromático. Los ovocitos ovulados completan la meiosis con la separación de las cromátidas y la emisión del segundo cuerpo polar (segunda división reduccional) en el momento de la fecundación. Este proceso es inducido por la penetración del espermatozoide, completándose así el ciclo celular y la subsecuente transición desde un tipo de división meiótica a una mitótica (Moor y col., 1992; Fan y Sun, 2004).

Adquisición de la competencia meiótica

La capacidad que adquieren los ovocitos detenidos en el estadio de diplonema de progresar hacia la etapa reduccional de la meiosis, se denomina competencia meiótica (Szybek, 1972; Sorensen y Wassarman, 1976; Albertini y Carabatsos, 1998). Existen factores reguladores secretados por las células de la granulosa que mantienen la detención de la meiosis hasta que se produce el pico de LH, momento en el que las células foliculares se separan del ovocito impidiendo así la llegada de más sustancias inhibitorias (Coskun y col., 1995; Fan y Sun, 2004). Sin embargo, se sabe que la maduración meiótica es independiente del estimulo hormonal, ya que cuando los ovocitos son removidos de los folículos antrales (eliminando de este modo la comunicación con las células de la granulosa) y cultivados in vitro en ausencia de LH, progresan en la meiosis espontáneamente hasta M II (Sorensen y Wassarman, 1976; Downs, 1993; Edwards, 2000; Fan y Sun, 2004; Hashimoto, 2009). 
Factor promotor de la maduración.

La clave para entender la regulación de la división meiótica fue descubierta hace 41 años (1971) por Masuri y Market en ovocitos de Rana pipiens, donde se encontró un componente celular esencial llamado factor promotor de la maduración (FPM). Posteriormente se determinó que este factor participaba tanto en la división meiótica como en la mitótica, por lo que actualmente se lo considera el regulador universal del ciclo celular o factor promotor de metafase. En ovocitos de Xenopus sp fue caracterizado en su estado activo como una fosfoproteína (Dunphy y col., 1988; Gautier y col., 1988; Doree, 1990).

Los sustratos sobre los que actúa el FPM, son: a) la histona H1 cuya fosforilación interviene en la condensación de los cromosomas; b) las láminas que forman una malla fibrilar sobre la cara interna de la membrana nuclear y cuya fosforilación provoca la despolimerización y consiguiente ruptura de la membrana al final de la profase y c) la nucleolina ( $N^{\circ} 38$ o B23) que al ser fosforilada por el FPM provoca el desensamblaje del nucléolo durante la división celular (Belenguer y col., 1990; Peter, 1990; Josefsberg y col., 2000; Kanitz y col., 2001; Perry y Verlhac, 2009).

El FPM está constituido por dos subunidades. La subunidad pequeña que fue descubierta en levaduras, se denomina p34 y es una proteína quinasa (serina-treonina) de 34000 Daltons. Es codificada por el gen cdc2 perteneciente al grupo de genes cdc que controlan la división celular (Kanitz y col., 2001; Jones, 2004). Si bien esta subunidad está presente durante todo el ciclo celular, sufre modificaciones significativas mediante fosforilaciones activantes y desactivantes de determinados aminoácidos. La subunidad mayor del FPM es la ciclina y es una proteína de 56000 Daltons (p56). Es codificada por el gen cdc13 que fue clonado en levaduras y presenta una secuencia semejante a la ciclina B encontrada en numerosos 
animales de la que se considera la subunidad reguladora. El inicio de la metafase es regulado por la activación de la p34 y su asociación con la subunidad mayor (Jessus y Ozon, 1993; Perry y Verlhac, 2009).

Se conocen tres tipos de ciclinas: A, B1 y B2 (Kobayashi y col., 1991). En anfibios la ciclina A aparece cuando se rompe la vesícula germinal y no se encuentra asociada a la subunidad p34. A diferencia de lo que ocurre en porcinos, donde la ciclina A permanece constante a través de la maduración, en anfibios su concentración declina entre la anafase y la telofase, aumentando nuevamente durante la activación del ovocito (Kobayashi y col., 1991). En porcinos la ciclina B1 no presenta cambios detectables durante la maduración pero en anfibios se duplica durante el período que se extiende desde profase a metafase (Westendorf y col., 1989; Kobayashi y col., 1991). La ciclina B2 es la más abundante y su papel es el más conocido, ya que es la responsable de conducir a los ovocitos a MII durante la maduración del ovocito. Sus niveles no son fluctuantes en porcinos, pero en anfibios e invertebrados marinos aumentan marcadamente antes de la ruptura de la vesícula germinal, para luego disminuir durante la transición de anafase a telofase por un proceso dependiente de la ubiquitina (Kobayashi y col., 1991).

Además de los procesos de fosforilación y desfoforilación hay otros factores que actúan en la activación del FPM, como la disminución en la concentración de AMPc que precede a la ruptura de la vesícula germinal (Schultz y col., 1983; Perry y Verlhac, 2009). El pico de LH interrumpe las uniones gap entre el ovocito y las células foliculares lo que impide el ingreso de AMPc, esto explica la detención de la meiosis mientras los ovocitos están rodeados por las células foliculares (Bornslaeger y col., 1986; Sun y col., 2009; Zhang y col., 2009). Además, en respuesta a la LH se produce la liberación de iones calcio de los depósitos endógenos de las células foliculares, lo que contribuye a la ruptura de la vesícula germinal (Downs, 1993). 
Luego de la ruptura de la vesícula germinal aparece un factor citostático (FCS) que controla la detención en metafase II y alcanza una concentración máxima cuando el ovocito Ilega a esta etapa (Masui y Clark, 1979; Paules y col., 1989; Perry y Verlhac, 2009). El FCS está constituido por una fosfoproteína de 39000 Daltons (p39) producto del gen c-mos y por una quinasa 2 que es producto del gen cdk2 dependiente de ciclina, que es muy sensible a los iones calcio y actúa inhibiendo la proteólisis de la ciclina (Watanabe y col., 1991; Gabrielli y col., 1993). Mientras la ciclina no es degradada, el FPM permanece activo. Otra proteína quinasa importante en la regulación del ciclo celular meiótico es la MAP quinasa, la cual fosforila proteínas cromosómicas importantes para mantener a la cromatina en un estado condensado durante la transición de meiosis I a meiosis II y previene la formación de la envoltura nuclear por fosforilación de las láminas nucleares (Gil Villa y col., 2007).

Regulación hormonal de la maduración en mamíferos

Durante la fase de crecimiento del ovocito la hipófisis secreta cantidades crecientes de FSH que estimula la proliferación de las células de la granulosa y la formación de nuevos receptores para LH sobre la superficie de las mismas. Poco después del período de crecimiento inicial del folículo, la hipófisis comienza a secretar LH (hormona responsable de iniciar la maduración del ovocito). En respuesta a ella se rompe el bloqueo meiótico: los cromosomas terminan la primera división meiótica y se elimina el primer corpúsculo polar dando como resultado un ovocito II que continúa la división hasta la metafase II.

Las hormonas LH y FSH inducen a las células de la granulosa a sintetizar y liberar cantidades crecientes de estrógenos, que aumentan el número de receptores para LH y estimulan la síntesis de inhibina. En respuesta a este aumento de estrógenos e inhibina circulantes, la hipófisis disminuye la secreción de FSH. Los estrógenos a su vez, cuando se 
encuentran a bajas concentraciones, inhiben la secreción de LH. Sin embargo, a altas concentraciones ejercen un efecto contrario, estimulando la secreción de LH por la hipófisis, ya que actúan sobre el hipotálamo haciendo que este libere GnRH (hormona liberadora de gonadotrofinas). Cuando los estrógenos circulantes se elevan, la LH aumenta mientras que la FSH disminuye (Figura 3).

Figura 3. Regulación hormonal de la maduración

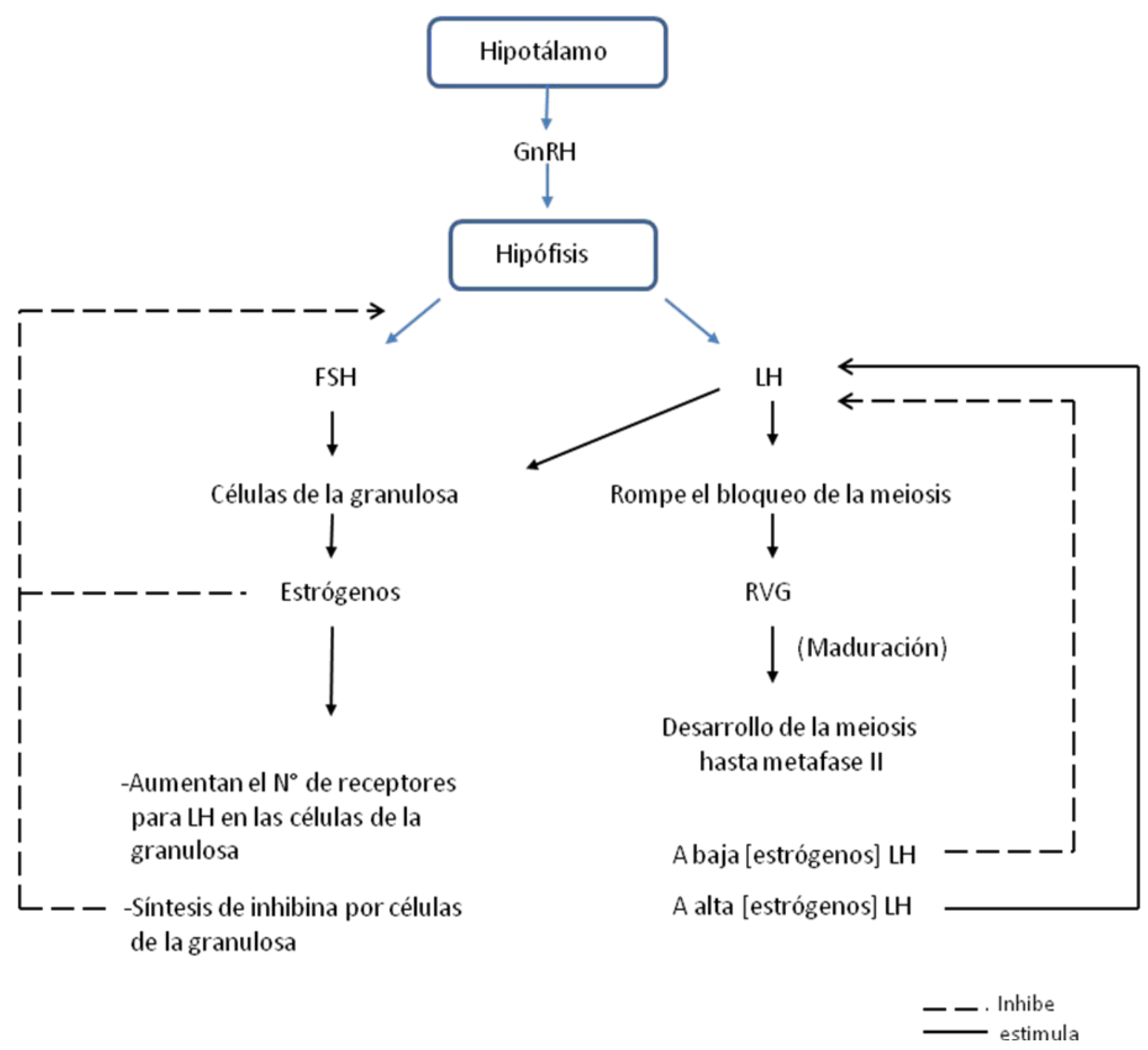


La oleada de LH puede aumentar la concentración de AMPc en las células de la granulosa y en respuesta a este aumento las células foliculares sintetizan ácido hialurónico que provoca que éstas se separen del ovocito (Larsen y col., 1986).

Figura 4. Ovocitos madurados in vitro rodeados de células foliculares que forman el cúmulus oophorus. El ovocito rodeado por el cúmulus se denomina complejo Ovocito- Cúmulus (COC) $(45 \mathrm{X})$.

\subsection{Ovulación}

Al final de la fase folicular (proestro), cuando los niveles de estradiol alcanzan su valor máximo, se produce un cambio en el efecto que esta hormona ejerce a nivel neuronal y de la hipófisis. La potente retroalimentación negativa del estradiol cambia a positiva a través de un mecanismo que aún permanece poco claro. La retroalimentación positiva ejercida por el estradiol produce un pico en la liberación de $\mathrm{GnRH}$, que ejerce a su vez un aumento en la capacidad de respuesta gonadotrófica, provocando el pico de liberación preovulatorio de LH. 
Los picos preovulatorios de GnRH han sido demostrados en ratas, ovinos, bovinos, monos, equinos, cerdos y conejos (Perry y Perry, 2009; Christian y Moenter, 2010; Tomikawa y col., 2010). Las hembras de distintas especies ovulan una o varias veces en el año. En estos casos, señales ambientales como la cantidad y tipo de luz durante el día, estimulan al hipotálamo para liberar GnRH que a su vez induce a la hipófisis a liberar FSH y LH.

La ovulación se produce durante el período denominado estro en todas las especies domesticas con excepción del bovino en el que la ovulación se produce en el metaestro. La ovulación espontánea en el bovino ocurre entre las 10 a 20 horas posteriores a la terminación del celo y es desencadenada por el pico de LH que provoca, como primer evento, un aumento del flujo sanguíneo en el folículo ovulatorio mediado por agentes vasoactivos tales como histamina, quininas, prostaglandinas y lipooxigeneasas. Posteriormente se produce un edema en las tecas interna y externa, se disocia el cúmulus oophorus, se interrumpe la inhibición de la meiosis y se elimina el primer corpúsculo polar. El pico preovulatorio de LH provoca la despolarización de la membrana plasmática de uno o más de los tipos celulares presentes en el folículo ovárico maduro. A medida que el folículo avanza en su desarrollo hacia la ovulación se produce una reacción inflamatoria aguda. Aumenta la despolarización de las células foliculares, se generan potenciales de acción y cambios en la concentración del $\mathrm{Ca}^{++}$del citosol, que contribuyen a la desintegración de tejido intacto de la superficie del ovario. Este proceso de degradación del tejido conectivo que separa el folículo de la superficie ovárica inicia la formación del estigma (área extremadamente delgada del ápice folicular). La prostaglandina E2 (PGE2) estimula al activador del plasminógeno, que actúa transformando el plasminógeno en plasmina, que es la encargada de activar la colagenasa que lisará el tejido conectivo del estroma ovárico. La prostaglandina F2 $\alpha$ (PGF2a) provoca la ruptura de los lisosomas con la consecuente liberación de las enzimas contenidas en su interior, las que sumadas a la actividad 
de la plasmina, culminan con la formación del estigma. Las contracciones ováricas producidas por la PGF2 $\alpha$ provocan la ruptura del folículo y finalmente la liberación del ovocito rodeado por su cúmulus (Hafez, 1996; Palma, 2001a) (Figura 5).

Figura 5. Mecanismo simplificado de la ovulación (Callejas 1996).

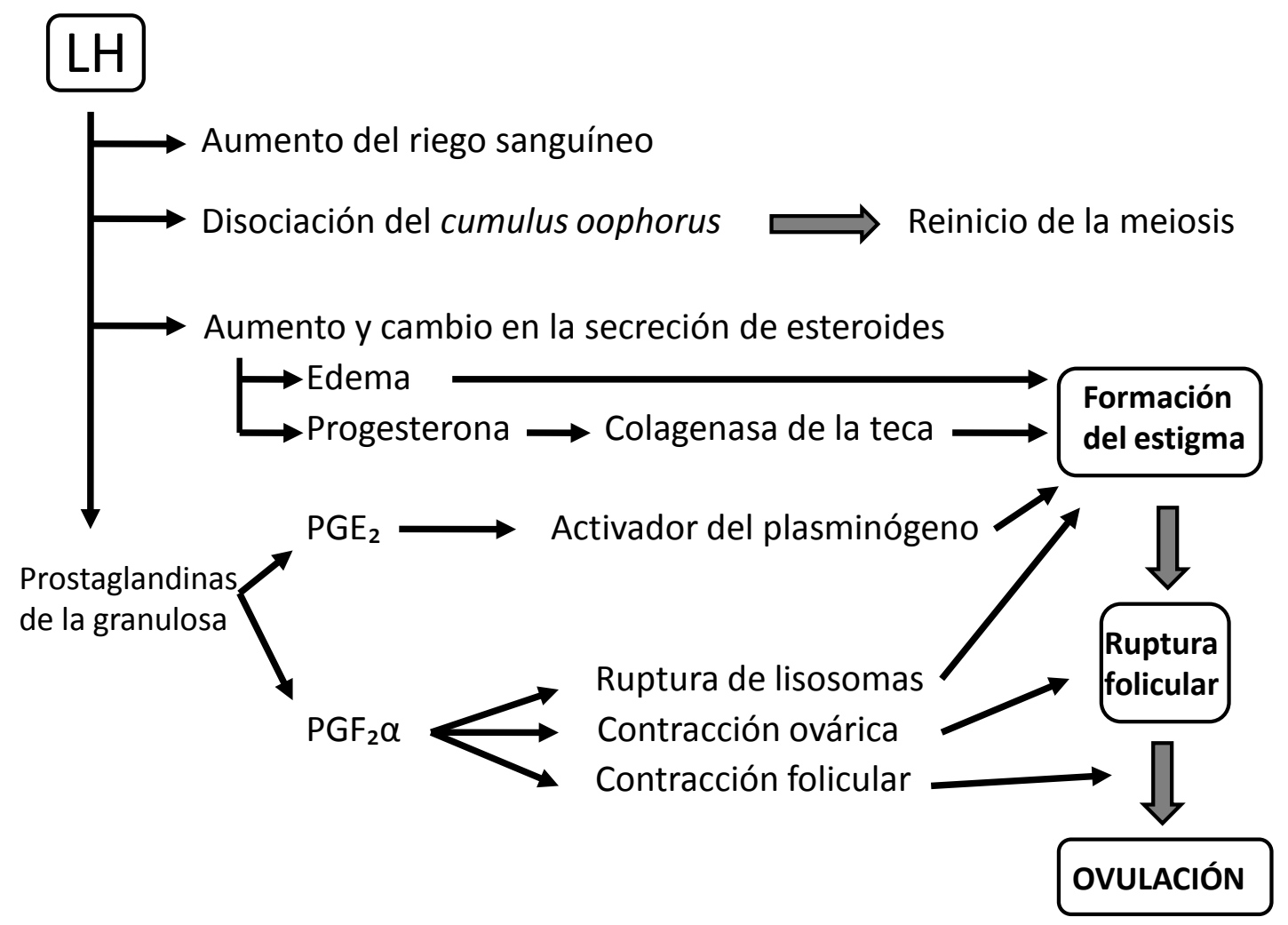




\subsection{Espermatozoide}

\subsubsection{Características del espermatozoide de mamíferos}

Los espermatozoides surgen de una población de células madres espermatogónicas (spermatogonial stem cells) que derivan a su vez de las células germinales primordiales (CGP) presentes a lo largo del desarrollo fetal. Las CGP constituyen una población celular transitoria que se describió por primera vez como un pequeño grupo de células fosfatasa alcalina positivas en el epiblasto del embrión de ratón de 7 - 7,25 días (Phillips y col., 2010). Durante la formación del alantoides, las CGP son desplazadas fuera del embrión antes de iniciar la migración a través del intestino caudal hacia las gónadas indiferenciadas. Las CGP darán lugar a los gonocitos, que son encerrados en los cordones testiculares formados por células precursoras de las células de Sértoli y de las células mioides peritubulares. El término "gonocito", es una nomenclatura general que comprende a las proespermatogonias mitóticas (M), proespermatogonias T1 y proespermatogonias T2. Las proespermatogonias M se encuentran en el centro de los cordones testiculares, lejos de la membrana basal de los túbulos seminíferos. Estas células se multiplican activamente hasta convertirse en proespermatogonias T1 entrando en arresto mitótico (G0) rápidamente. En ratones, durante la primera semana posterior al nacimiento, los gonocitos reanudan su proliferación marcando su transición a proespermatogonia T2 concomitantemente con la migración hacia la membrana basal de los túbulos seminíferos. Las proespermatogonias T2 colonizan la membrana basal de los túbulos y dan lugar al pool inicial de células madre espermatogónicas que mantienen la espermatogénesis a lo largo de toda la vida reproductiva (Phillips y col., 2010).

La espermatogénesis es un proceso complejo y dinámico por el que se generan los espermatozoides. Este fenómeno se encuentra sometido a una fuerte regulación hormonal 
(FSH, LH, testosterona y $17 \beta$ estradiol) e involucra cuatro eventos celulares importantes: 1) Espermatogoniogénesis, proceso continuo que involucra la división de las espermatogonias $\mathrm{A}$ que mantienen el pool de células madre y la producción de espermatogonias B para la producción de espermatozoides; 2) Diferenciación del espermatocito primario a partir de la espermatogonia B (última división mitótica) y la diferenciación de éste a espermatocito secundario con la posterior formación de espermátidas; 3) Espermiogénesis, proceso por el cual las espermátides sufren morfogénesis para convertirse en un espermatozoide maduro y motil y 4) Espermiación que consiste en la liberación de la espermátida elongada o espermatozoide que es el producto final de la espermatogénesis, hacia la luz tubular (Kopera y col., 2010; Shaha y col., 2010). Además de las células germinales en desarrollo, el epitelio seminífero se encuentra constituido por las células de Sertoli, encargadas de proveer soporte estructural y nutrición a las células germinales. Las células de Sertoli son células de citoplasma extenso, de forma piramidal, que sostienen el epitelio germinativo y constituyen el armazón del túbulo seminífero. Descansan sobre la membrana basal del túbulo y se adosan unas a otras por especializados complejos de unión que se localizan en sus porciones laterales y evitan que los diferentes estratos celulares germinativos penetren a la luz del túbulo seminífero, a menos que lo hagan a través de su citoplasma (Figura 6) (Kopera y col., 2010).

El espermatozoide de mamífero es el producto final del proceso de la gametogénesis en el macho. Es una célula con movimiento activo constituida por una cabeza y flagelo móvil o cola formada por cuello, pieza media, pieza principal y filamento terminal (Eddy y O’Brien, 1994; Eddy, 2006; Guzmán y col., 2007). 
Figura 6. Epitelio Seminífero (adaptado de Senger, 2005).

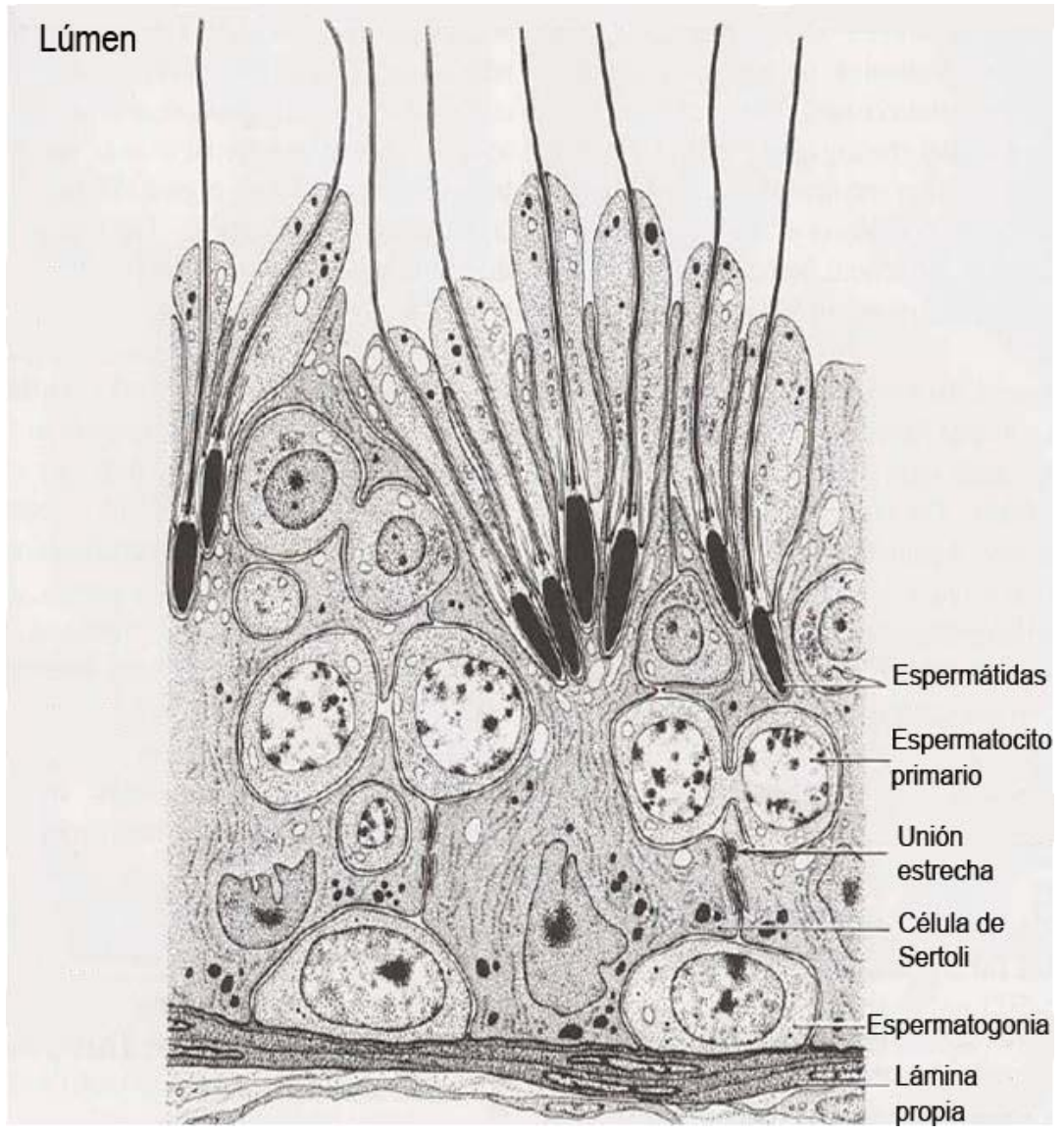

La cabeza del espermatozoide de mamífero contiene el núcleo con la cromatina fuertemente condensada y el acrosoma rodeado por una moderada cantidad de componentes del citoesqueleto y citoplasma. El acrosoma es una gran vesícula secretora que se encuentra localizada en el extremo anterior de la cabeza espermática. Se origina a partir del complejo de Golgi durante el estadio de espermátide y contiene enzimas necesarias para la penetración de la cubierta del ovocito. De estas enzimas la hialuronidasa y la acrosina juegan un rol central, al dispersar el cúmulus oophorus y provocar la lisis local de la zona pelúcida respectivamente. 
Este lisosoma especializado se encuentra constituido por una membrana acrosomal interna que rodea la porción anterior de la membrana nuclear y que se continúa ininterrumpidamente formando la membrana acrosomal externa, la cual se extiende cerca de la superficie interna de la membrana plasmática de la porción anterior de la cabeza. El acrosoma posee dos segmentos, el casquete acrosómico o acrosoma anterior y el segmento ecuatorial por el cual el espermatozoide hace contacto con el ovocito en el momento de la fecundación (Figura 7). Durante la reacción acrosómica la membrana acrosomal externa y la membrana plasmática de la cabeza del espermatozoide se fusionan formando vacuolas en la superficie que permiten la salida del contenido acrosomal (Eddy y O’Brien, 1994; Romar Andrés, 2001; Guzmán y col., 2007; Bedford, 2008).

Figura 7. Organización de la cabeza del espermatozoide mamífero (Florman y Ducibella, 2006).

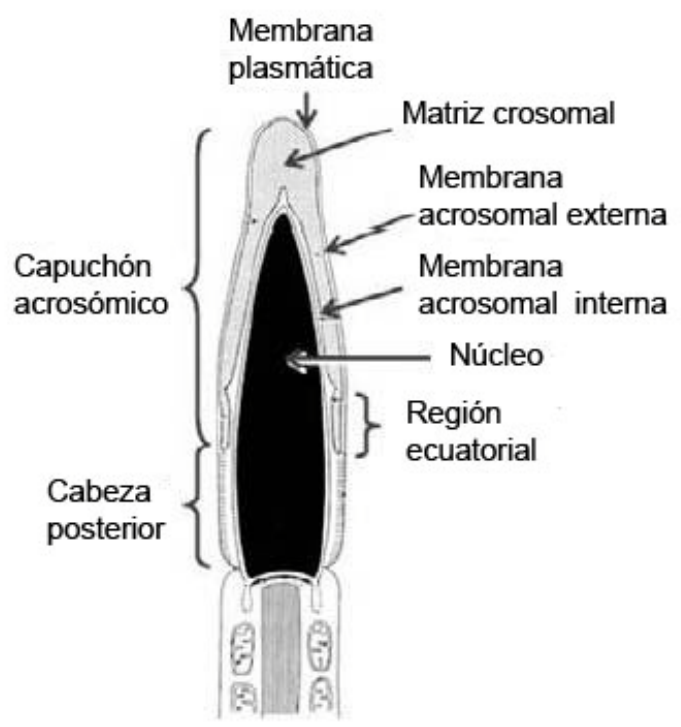


La cola de los espermatozoides mamíferos se encuentra constituida por varios componentes funcionalmente dependientes. Aunque el tamaño y la forma de estos pueden variar de una especie a la otra, su organización estructural es muy similar. La cola puede dividirse en cuatro segmentos: el cuello, la pieza media, la pieza principal y la pieza final, todas ellas rodeadas por una membrana plasmática común (Figura 8).

Figura 8. Características generales del espermatozoide mamífero (Eddy, 2006).

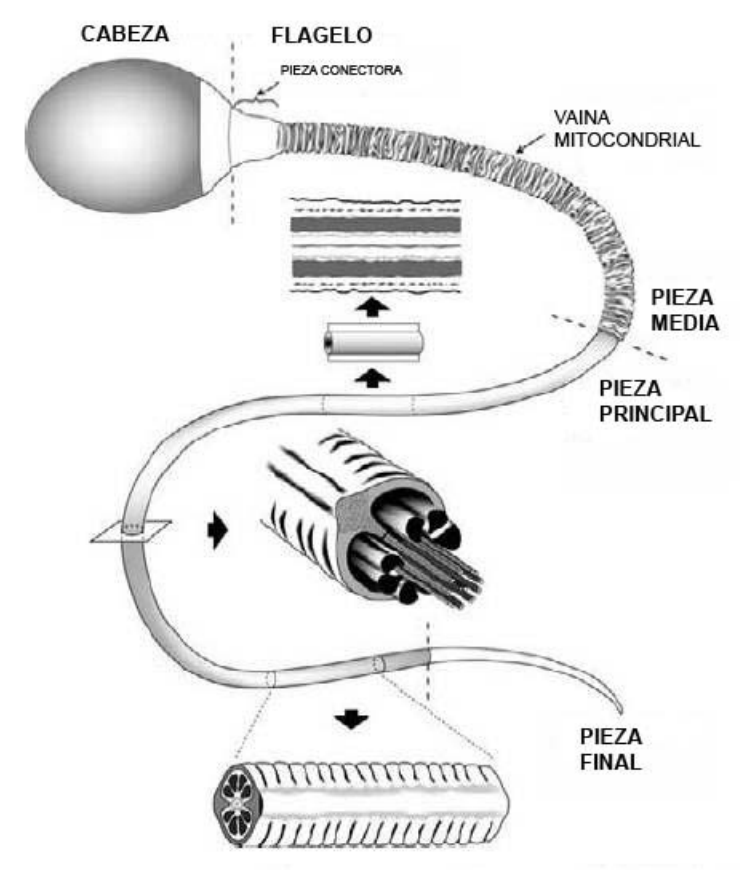

El axonema es una estructura común a todas las regiones de la cola, se localiza centralmente, y es el aparato motor del espermatozoide. Está compuesto por un par microtúbulos centrales rodeados de nueve pares o dobletes espaciados de modo uniforme $(9+$ 2). Los nueve dobletes están rodeados por nueve fibras densas externas. En cada doblete, el 
microtúbulo mas interno proyecta dos brazos de dineína hacia el doblete adyacente, en el sentido de las agujas del reloj, uno más externo y otro más interno. Los nueve pares están conectados entre sí por puentes proteicos de nexina. Rodeando a los dos túbulos centrales hay una vaina o filamento helicoidal formado a partir de las proyecciones radiales (Figura 9). Las estructuras que rodean al haz de fibras axiales permiten diferenciar las piezas intermedia y principal de la cola del espermatozoide. En la pieza intermedia el axonema se encuentra rodeado por una vaina de mitocondrias que se retuercen regularmente alrededor de él unas 32 veces. Estas mitocondrias son las encargadas de generar el ATP necesario para agitar el flagelo e impulsar el espermatozoide. La pieza principal está rodeada por una cubierta fibrosa estriada. El filamento terminal de la cola es la porción más distal de la cola y comienza en el punto donde desaparece la cubierta fibrosa (Gilbert, 2005a; Otero, 2008).

Figura 9. Esquema de un flagelo (corte transversal) (adaptado de Márquez y col., 2011).

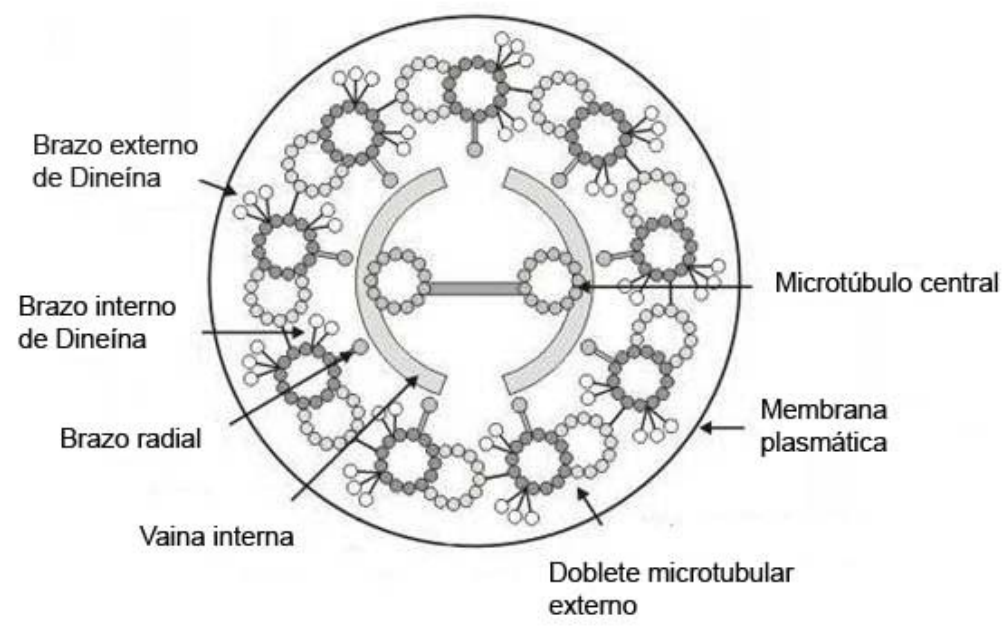


Todas estas estructuras especializadas que posee el espermatozoide están en relación con su actividad funcional única. El acrosoma contiene enzimas esenciales para la fecundación y el flagelo contiene las fuentes de energía y la maquinaria necesaria para el movimiento. El rol de estas estructuras es asegurar la liberación del material nuclear, contenido en la cabeza del espermatozoide, dentro del citoplasma del ovocito en donde la combinación del pronúcleo femenino y masculino formará el cigoto (Eddy y O’Brien, 1994).

\subsubsection{Maduración del espermatozoide}

Los espermatozoides liberados al lumen desde los túbulos seminíferos no han completado su diferenciación por lo que son incapaces de fertilizar el ovocito. La capacidad fecundante se consigue durante el pasaje de la gameta a través de las distintas regiones del epidídimo. Junto a la adquisición de esta capacidad el espermatozoide sufre una serie de cambios madurativos. El primero de ellos en ser reconocido fue la adquisición de la capacidad de moverse hacia adelante (motilidad progresiva). Esto fue observado posteriormente en numerosas especies de vertebrados superiores, como la lagartija, el ratón, la rata, el hámster, conejillo de indias, el conejo, el jabalí, el carnero, el toro y los primates. La maduración del potencial de motilidad espermática implica no solo un aumento cuantitativo en el porcentaje de espermatozoides motiles sino también, una diferencia cualitativa en el patrón de movilidad. Además de la adquisición de esta capacidad, los espermatozoides del epidídimo desarrollan la habilidad de sufrir eventualmente la reacción acrosómica, reconocer y unirse a la zona pelúcida, y la capacidad de fusionarse a la membrana vitelina del ovocito (Rosati y col., 2000; Romar Andrés, 2001; Eddy, 2006; Otero, 2008).

Concomitantemente a estos cambios funcionales, durante el tránsito epididimal, los espermatozoides sufren múltiples cambios estructurales, los cuales incluyen la migración de la 
gota citoplasmática (remanente citoplasmático de la espermátida) a lo largo del flagelo del espermatozoide, remodelación acrosomal, cambios en la cromatina y en algunas de las organelas del flagelo, y cambios en los lípidos de membrana y proteínas de superficie (Bedford y Cooper, 1978; Rosati y col., 2000; Robaire y col., 2006).

\subsubsection{Capacitación del espermatozoide}

Aquellos espermatozoides que han atravesado el epidídimo aún no han completado el proceso de maduración funcional, por lo que continúan siendo limitados en su capacidad fecundante (Florman y Ducibella, 2006). Durante la eyaculación, el espermatozoide entra en contacto con las secreciones de las glándulas genitales accesorias y alcanza el aparato genital femenino. En condiciones in vivo, durante la migración de los espermatozoides por el tracto genital de la hembra, ocurre la "capacitación espermática" bajo la influencia de glicosaminoglicanos como la heparina o el ácido hialurónico (Romar Andrés, 2001). La capacitación consiste en alteraciones de la membrana plasmática, tales como la eliminación de los factores de decapacitación y la eliminación del colesterol, la entrada de $\mathrm{Ca}^{++}$a la célula, el aumento del pH intracelular, y el aumento de la fosforilación proteica, así como la hiperpolarización de la membrana. (Florman y Ducibella, 2006; Schatten y Constantinescu, 2008).

\subsubsection{Hiperactivación y quimiotaxis}

Los espermatozoides sufren además de la motilidad progresiva, adquirida durante la maduración epididimal, un tipo de movimiento (característico para cada especie) llamado motilidad hiperactiva. La primera se caracteriza por un movimiento flagelar vigoroso, de baja amplitud y larga longitud de onda y relativamente simétrico que da como resultado un rápido 
movimiento de avance lineal. Por otro lado, luego de un determinado período de tiempo en el tracto reproductivo femenino, el espermatozoide desarrolla movimientos de hiperactivación, caracterizados por movimientos flagelares como golpes de látigo, de alta amplitud y baja longitud de onda, asimétricos, y con una trayectoria de avance circular o irregular (Senger, 2005; Florman y Ducibella, 2006) (Figura 10). El fenómeno de hiperactivación se produce durante el proceso de capacitación, pero no se ha determinado aún con exactitud si la hiperactivación es una consecuencia de la capacitación o si ambos son procesos independientes que se producen de forma simultánea. Este fenómeno de hiperactivación serviría en primer lugar para facilitar el avance del espermatozoide a través del fluido viscoso del oviducto, así como también, a través de la matriz extracelular del cúmulus y de la zona pelúcida. En segundo lugar, la hiperactivación ayudaría al espermatozoide a ascender por el oviducto hasta el sitio de fecundación al permitir que éste se libere de la adhesión transitoria ejercida entre la gameta y el epitelio oviductal (Florman y Ducibella, 2006).

Los espermatozoides de varias especies de mamífero son orientados hacia el ovocito mediante el fenómeno de quimiotaxis. Los espermatozoides son direccionados hacia un gradiente de concentración de sustancias quimioatrayentes aportadas por el líquido folicular, el ovocito maduro y las células del cúmulus (Eisenbach y Giojalas, 2006). Además se ha descubierto que los espermatozoides podrían orientar su motilidad siguiendo un gradiente térmico superficial existente a lo largo del oviducto ya que, existe en el oviducto una diferencia de 1 a $2{ }^{\circ} \mathrm{C}$ entre el sitio de fecundación y el de almacenamiento espermático (Sun y col., 2005). Los espermatozoides serían guiados al sitio de fecundación siguiendo un gradiente térmico y alcanzarían el COC por quimiotaxis cuando los espermatozoides se encuentran a pocos milímetros de este (Eisenbach y Giojalas, 2006; Florman y Ducibella, 2006). 
Figura 10. Espermatozoide hiperactivado (Florman y Ducibella, 2006).

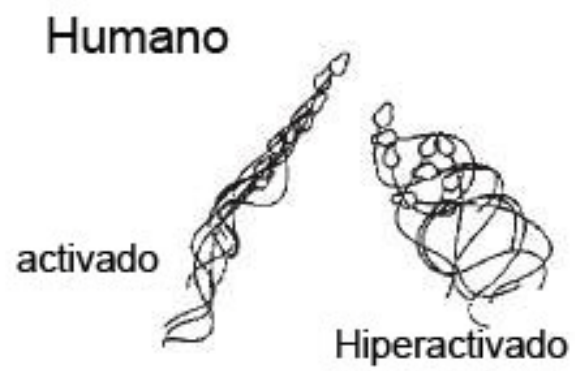

Cerdo

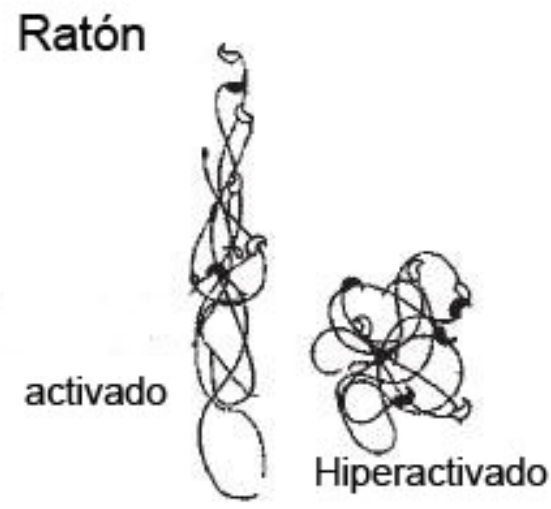

Conejo

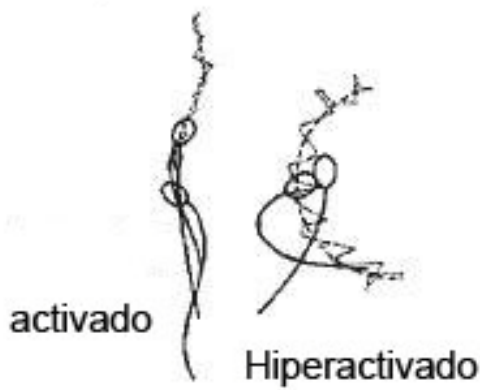

\subsection{Producción de embriones in vitro (PIV)}

\subsubsection{Maduración de los ovocitos in vitro (MIV)}

Los ovocitos de mamíferos tienen la capacidad de madurar espontáneamente hasta el estadio de MII cuando son liberados desde un folículo preovulatorio o cuando son cultivados in vitro incluso en ausencia de hormonas, lo que se denomina maduración in vitro (MIV) (Wassarman y col., 1979; Eppig y Downs, 1984; Kanitz y col., 2001). Este proceso, puede evaluarse mediante la observación de los cromosomas en la placa metafásica (MII) y la 
presencia del segundo corpúsculo polar (maduración nuclear). Sin embargo, existe un tipo de maduración del ovocito que no puede ser observada a nivel del microscopio óptico denominada maduración citoplasmática que comprende numerosos eventos moleculares como la síntesis y la fosforilación de proteínas relacionadas con la meiosis y con la formación del pronúcleo femenino (Hunter y Moor, 1987; Fulka y col., 1991). Además, durante la maduración las mitocondrias migran hacia una posición perinuclear mientras que los gránulos corticales se desplazan hacia la periferia (ubicándose por debajo del oolema) para ejercer un bloqueo efectivo contra la polispermia en el curso de la fecundación (Cran y Cheng, 1986; Cran, 1987). La maduración citoplasmática puede ser estimada de forma indirecta, evaluando diferentes parámetros, como la capacidad de formación del PNM (Funahashi y Day, 1993; Funahashi y col., 1994; Wang y col., 1997), el contenido intracelular de glutatión (GSH) (Abeydeera y col., 1998; Funahashi y col., 1996), la exocitosis del contenido de los gránulos corticales al espacio perivitelino (Wang y col., 1997) y el desarrollo embrionario temprano luego de la FIV (Abeydeera y col., 1998).

Estudios in vitro revelaron que durante el proceso de maduración del ovocito, es fundamental la presencia de aminoácidos y sustratos energéticos (Sutton y col., 2003), ya que se produce un aumento en la actividad glucolítica, en la oxidación de la glucosa y de la glutamina (Zuelke y Brackett, 1993) y en el metabolismo oxidativo del piruvato luego de la ruptura de la vesícula germinal (Kim y col., 1993; Rieger y Loskutoff, 1994). Se ha demostrado además, que hormonas presentes en el medio de maduración como la LH, pueden afectar los procesos celulares pre y post desarrollo preimplantacional (Rose y Bavister, 1992; Trounson y col., 2001).

La presencia de glucosa en bajas concentraciones se vuelve indispensable para mantener el desarrollo competente cuando la maduración in vitro se desarrolla en condiciones de alta 
concentración de oxigeno (Hashimoto y col., 2000). El aporte de pequeñas cantidades de glucosa resulta en una disminución de especies reactivas del oxigeno (ROS) e incrementa las concentraciones de GSH (Krisher, 2004). El GSH es un tripéptido que se forma a expensas de los aminoácidos cisteína, ácido glútamico y glicina (Chakravarthi y col., 2006) y que cuando se mantiene en el ovocito a ciertos niveles intracelulares constituye otro de los factores importantes que afectan la maduración citoplasmática (Luberda, 2005), tanto que ha llegado a ser considerado como un indicador de la misma (de Matos y col., 1995; Funahashi y col., 1996; Luberda, 2005). En hámster (Perreault y col., 1988) y porcinos (Yoshida y col., 1992a, b; 1993; Luberda, 2005) se observó que el GSH cumple un rol muy importante en la decondensación del núcleo de los espermatozoides y la posterior formación del pronúcleo masculino debido a que, durante la fecundación, se oxida (GSSG) al reducir los puentes disulfuro de la protaminas que empaquetan el material nuclear. Por otro lado, el mantenimiento de los niveles de GSH intracelular en el ovocito de mamíferos durante la maduración in vitro, es de suma importancia para el desarrollo de embriones en cultivo (Gardiner y Reed, 1994; de Matos y Furnus, 2000). Se ha demostrado que el GSH posee una gran capacidad como agente reductor de peróxido de hidrógeno y peroxilípidos (Meister, 1988), actividad mediada por la enzima glutatión peroxidasa, que oxida al GSH y protege a los embriones y ovocitos de la peroxidación (Takahashi y col., 1993; Gardiner y Reed, 1994).

La utilización de modelos de maduración in vitro permitió estudiar los mecanismos involucrados en la regulación de la maduración meiótica. Uno de estos mecanismos está relacionado con el AMPc que actúa como agente regulador de la detención meiótica en profase I (diplonema) ya que se ha demostrado que, mientras una disminución en su concentración provoca el cese de la detención de la meiosis tanto in vivo como in vitro, la estimulación de la síntesis de AMPc, inhibe la ruptura de la vesícula germinal (Masui, 2001; Sun y Nagai, 2003; 
Sun y col., 2009; Zhang y col., 2009). El otro mecanismo regulador está ligado al nivel intracelular de calcio e involucra a la hormona LH que actúa aumentando los niveles de este ion de dos formas: movilizando el calcio libre almacenado en los depósitos intracelulares (Hertelendy y col., 1989; Sun y Nagai, 2003) y estimulando la entrada de calcio a través de los canales que se encuentran en el oolema (Peres, 1987).

\subsubsection{Fecundación in vitro (FIV)}

En los mamíferos la fecundación consiste en una serie programada de eventos complejos que afectan a las gametas masculina y femenina (Figura 11). Se inicia con la fusión de las membranas plásmaticas del espermatozoide y del ovocito y finaliza con la formación de la cigota. Sólo los ovocitos que han madurado (maduración meiótica y citoplasmática) pueden ser fecundados, desarrollar normalmente hasta el estadio preimplantacional de blastocisto y dar origen a fetos viables (Moor y Trounson, 1977; Schroeder y Eppig, 1984; Gil Corbalán, 2001). La fecundación in vitro (FIV) se ha definido como la unión o cocultivo de espermatozoides capacitados y ovocitos maduros de forma que la penetración espermática ocurra fuera del tracto genital femenino (Martínez y col., 1989). 
Figura 11. Secuencias de eventos básicos de la fecundación en mamíferos

(Whittingham, 1979).

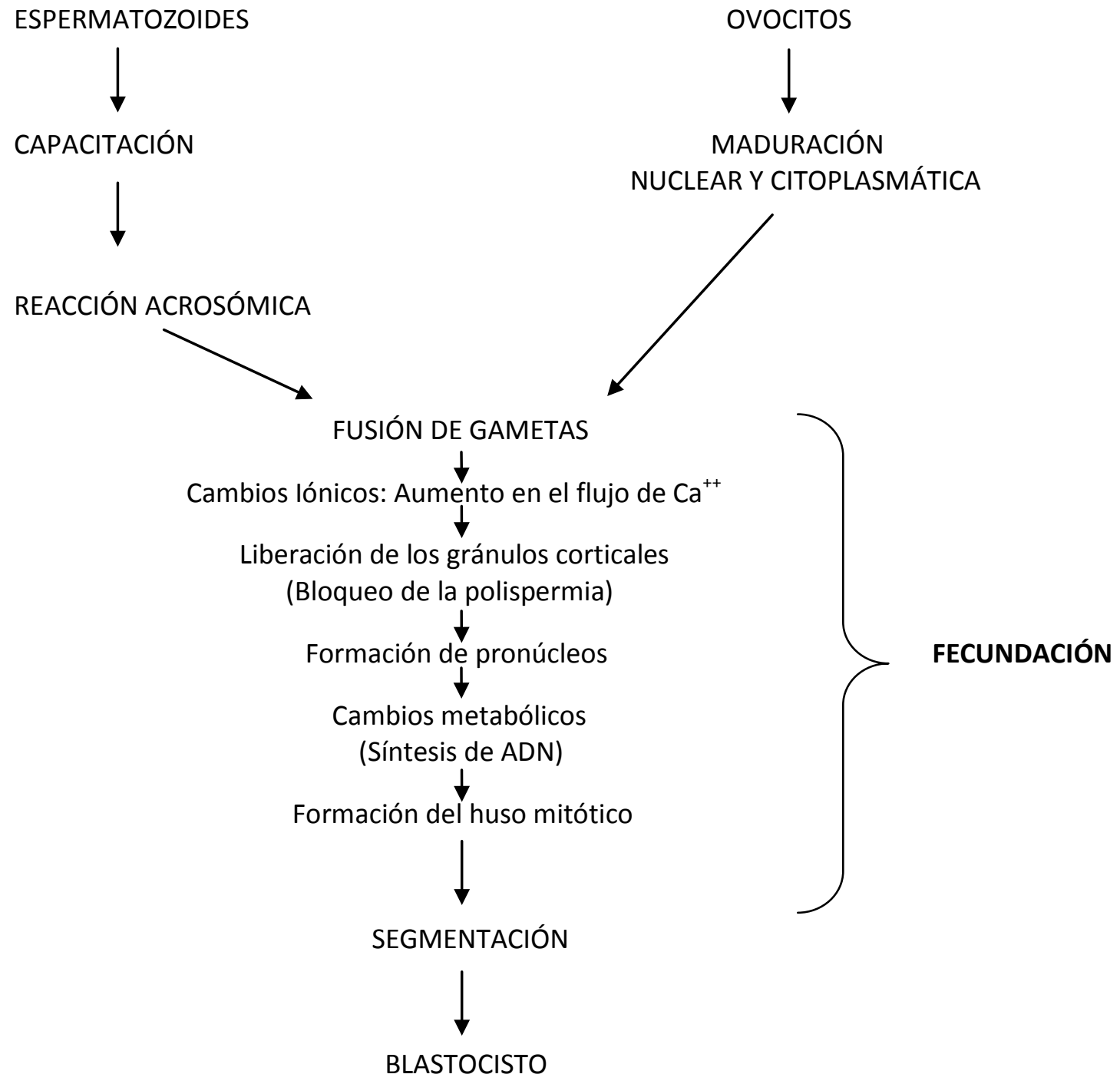

\subsubsection{Capacitación in vitro de espermatozoides de mamífero}

Las primeras investigaciones demostraron que los espermatozoides de mamíferos podían capacitarse in vitro en fluidos de origen biológico como el oviductal y folicular (Chang, 1968). Sin 
embargo, la composición de estos fluidos es tan compleja que hizo difícil determinar cuáles eran los componentes involucrados en la inducción de la capacitación hasta que Toyoda y colaboradores en 1971 publicaron la primera FIV exitosa en un medio químicamente definido, suplementado con albúmina o suero (Toyoda y col., 1971). En 1979 Bedford definió a la capacitación como el conjunto de cambios fisiológicos que preparan al espermatozoide para fertilizar a un ovocito maduro (Chang, 1984). Los mecanismos de capacitación son poco conocidos pero se sabe que provocan cambios bioquímicos y ultraestructurales que conducen a la eliminación y/o modificación de componentes adheridos a la membrana del espermatozoide, cambio de la composición lipídica de la membrana espermática, aumento de la permeabilidad a los iones $\mathrm{Ca}^{++}$, cambio en el $\mathrm{pH}$ interno y un incremento de la permeabilidad y del metabolismo celular (Palma, 2001b, Breitbart y col., 2005; Marquez y Suarez, 2007; Gadella y col., 2008; Wertheimer y col., 2008).

Los estudios realizados empleando sistemas in vitro aportaron información sobre los diversos factores que afectan a la capacitación de los espermatozoides (Figura 12), entre ellos la temperatura juega un rol preponderante (Mahi y Yanagimachi, 1973). Fluctuaciones de sólo 0,5 ${ }^{\circ} \mathrm{C}$ durante la incubación de los espermatozoides modifican el estadio físico de los lípidos de la membrana, lo que se traduce en una mayor o menor fluidez de la misma (Holt y North, 1986).

Otro factor a tener en cuenta es la composición del medio de capacitación/fecundación ya que la presencia o ausencia de algunos componentes puede disminuir la eficiencia de la capacitación, como por ejemplo, medios deficientes en calcio (Yanagimachi y Usui, 1974; Visconti y col., 1998; Gil Corbalán, 2001; Salicioni y col., 2007), bicarbonato (Visconti y col., 1998; Salicioni y col., 2007), sustratos energéticos exógenos (Fraser y Quinn, 1981) o albúmina (Visconti y col., 1998; Gil Corbalán, 2001; Salicioni y col., 2007). Por otro lado, existen agentes como la taurina y la hipotaurina, que mejoran la eficiencia de la capacitación y aumentan la 
sobrevida de los espermatozoides (Bavister y col. 1976; Holmes y col., 1992; Barna y col., 1998). Además, se considera que estos factores podrían actuar como agentes antioxidantes protegiendo a los lípidos de membrana de la acción de oxidantes externos (Alvarez y Storey, 1983; Holmes y col., 1992) o de los radicales libres generados por su propio metabolismo (Aruoma y col., 1988). También existen evidencias que indican que la taurina y la hipotaurina actuarían como agentes osmorreguladores para estabilizar la membrana plasmática de los espermatozoides (Holmes y col., 1992).

Figura 12. Diagrama de los principales factores biológicos que tienen influencia sobre la fecundación in vitro.

PREPARACIÓN DEL SEMEN

Capacitación

Reacción acrosómica

Concentración de los espermatozoides

\section{PREPARACIÓN DE LOS OVOCITOS}

Maduración nuclear y citoplasmática

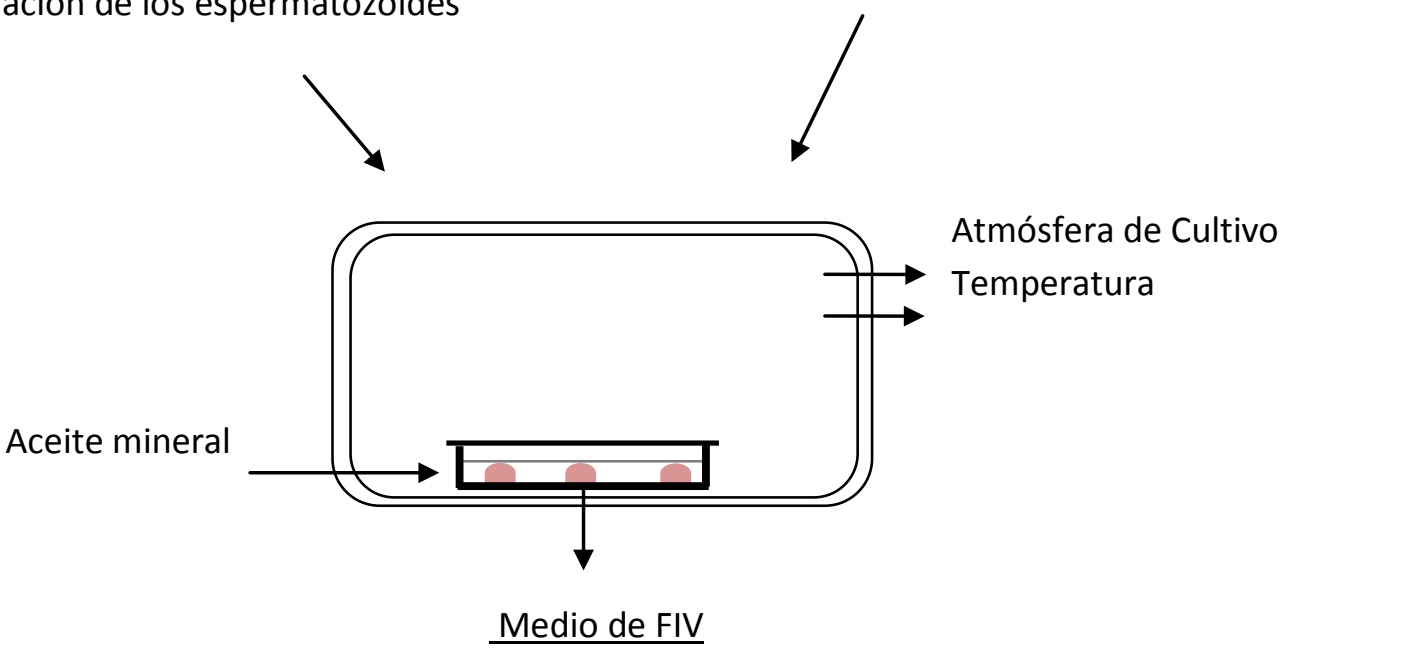

Osmolaridad; pH; lones: Calcio/Zinc/sodio; proteínas; aminoácidos 


\subsubsection{Movimientos hiperactivos in vitro.}

La penetración del cúmulus y la reacción acrosómica son dos procesos que van acompañados por fuertes movimientos del flagelo del espermatozoide denominados movimientos hiperactivos (Suarez, 2008). Estos movimientos, se producen cuando los espermatozoides se ponen en contacto con el medio de capacitación (Suarez, 2008). Los cambios que se producen en la membrana plasmática durante la capacitación, hacen que las cabezas de los espermatozoides se aglutinen durante la incubación hasta que luego de aproximadamente 2 horas se desaglutinan y nadan libremente mostrando movimientos del flagelo de amplitud cada vez mayor (Suárez y col., 1991), trazando figuras que asemejan a un ocho, para terminar con un movimiento de avance lineal (Ho y Suarez, 2001; Suarez, 2008). Cuando un espermatozoide muestra estos dos últimos movimientos, se dice que está hiperactivo. Esta descripción no se ajusta perfectamente a todas las especies. Sin embargo, el proceso de hiperactivación ya ha sido descripto en hámster, ratón, conejo, caprino, equino, bovino, porcino, mono y humano (Chang, 1984; Katz y col., 1989; Ho y Suarez, 2001; Suarez, 2008). Por otro lado, se ha podido comprobar que existe una correlación entre la capacidad de penetrar la zona pelúcida y la hiperactivación del flagelo (Flemming y Yanagimachi, 1982; Boatman y Robbins, 1991; Suarez, 2008). Entre los factores que afectan la hiperactivación de los espermatozoides podemos mencionar al ión calcio, cuya presencia en el medio de capacitación es esencial para desencadenarla (Suárez y col., 1992; Suarez, 2008). También es importante la presencia de iones bicarbonato (Boatman y Robbins, 1991; Suarez, 2008), iones potasio (Fraser, 1983) y algunos sustratos energéticos como el piruvato, la glucosa y el lactato (Suárez y col., 1992). 


\subsubsection{Reacción acrosómica in vitro y zona pelúcida}

La reacción acrosómica (RA) fue documentada por primera vez en 1950 por J.C. Dan (Dan, 1950). Este fenómeno consiste en la fusión de la membrana citoplasmática del espermatozoide con la membrana acrosomal externa en la zona apical de la cabeza espermática, lo que origina la liberación de las enzimas almacenadas en esta vesícula y la consiguiente exposición de la membrana acrosomal interna (Cardona Maya y col., 2006). El material lítico liberado desde el acrosoma digiere o disocia la cobertura glicoproteíca del ovocito generando un orificio por el cual el espermatozoide avanza atravesando la zona pelúcida (ZP) hasta alcanzar la superficie de la gameta (Cardona Maya y col., 2006; Yanagimachi, 2011).

El sitio preciso donde el espermatozoide comienza con la RA ha sido, por muchos años objeto de controversia. Yanagimachi y Phillips (1984) determinaron que la mayoría de los espermatozoides de hamster in vivo inician su RA mientras avanzan a través del cúmulus oophorus. Existen sin embargo investigadores, principalmente aquellos que trabajan realizando FIV de ratones, que señalan a la zona pelúcida como el sitio fisiológico más relevante para la RA. Recientemente, Jin y col. (2011) por medio de la grabación en video de FIV en ratón descubrieron que la mayoría de los espermatozoides presentan RA cuando se encuentran en el cúmulus, mientras unos pocos lo hacen cuando alcanzan la zona pelúcida (Yanagimachi, 2011). Esto coincide con lo observado en espermatozoides de cobayos, los cuales son capaces de unirse y penetrar la ZP luego de experimentar la RA. Sin embargo, en muchas especies la fecundación in vitro es posible aún sin un cúmulus oophorus intacto, por lo que indudablemente la ZP tiene la habilidad de inducir o acelerar este fenómeno, aunque no puede ser considerada la única estructura capaz de desencadenarlo (Jin y col., 2011; Yanagimachi, 2011) (Figura 13). 
Figura 13. Reacción acrosómica (Yanagimachi, 2011).
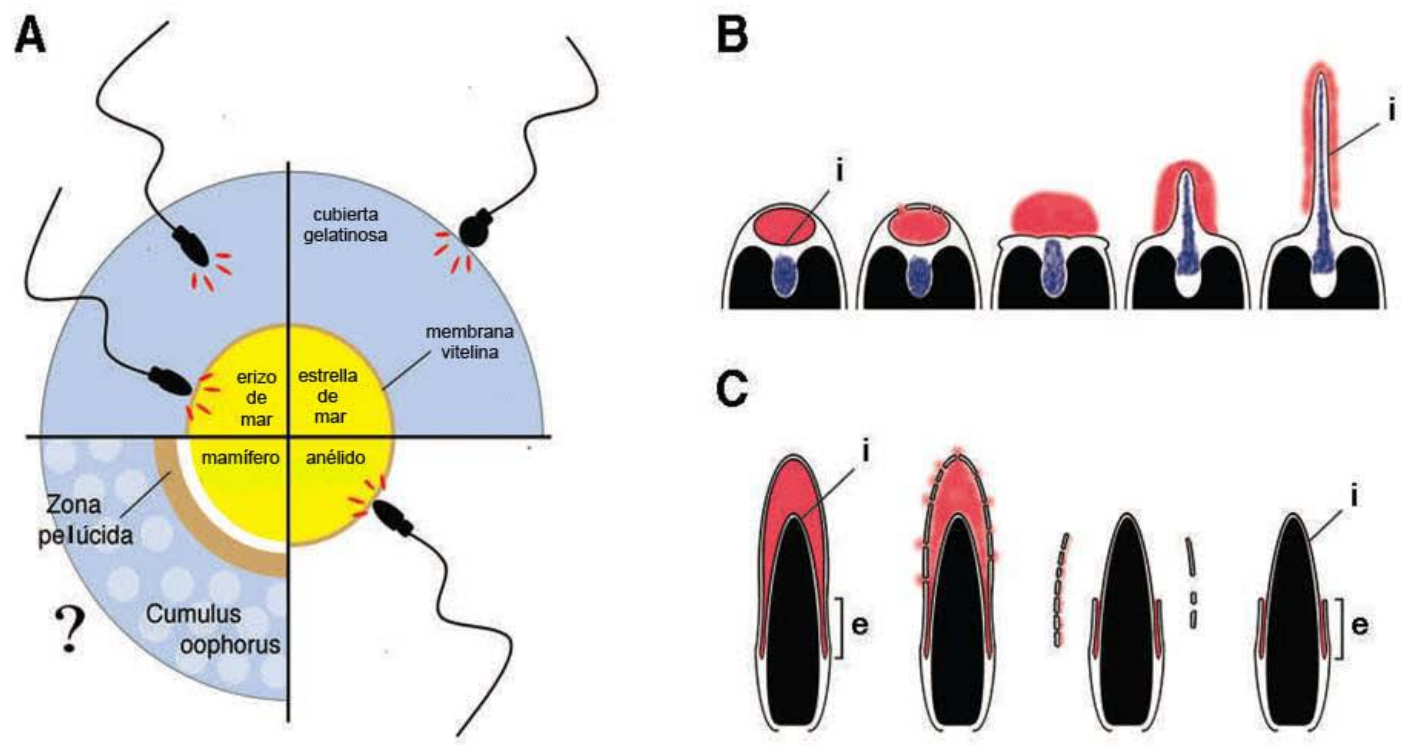

A: Sitio donde comienza la reacción acrosómica (RA) en: el erizo de mar (en la cubierta gelatinosa o en la membrana vitelina), la estrella de mar (periferia de la cubierta gelatinosa), los anélidos (membrana vitelina) y en los mamíferos (objeto de estudio de Jin y col., 2011). B: Corte longitudinal de la cabeza de un espermatozoide de erizo de mar mostrando diferentes estadios de RA; (i) membrana acrosomal interna. C: Sucesivos estadios de la RA en mamíferos; (i) membrana acrosomal interna que se mantiene invariable durante y después de la RA; (e) membrana plasmática del segmento ecuatorial.

La zona pelúcida es una cubierta extracelular glicoproteica que rodea a los ovocitos de mamíferos. Esta matriz glicoproteica se encuentra constituida por tres o cuatro tipos de glicoproteínas (ZP I, ZP II, ZP III y ZP IV) de acuerdo a las diferentes especies (Gupta y Bhandari, 2011) (Figura 14). Entre las funciones de la zona pelúcida podemos citar la regulación osmótica, la unión del espermatozoide, la inducción de la reacción acrosómica, el bloqueo de la polispermia, la contención de los blastómeros del embrión y la mejora de la supervivencia del ovocito y el embrión en el oviducto (Romar Andrés, 2001). 
La ZP representa la última barrera que el espermatozoide debe atravesar para poder fecundar al ovocito. Una vez que los espermatozoides alcanzan la ZP se unen a ella. Su penetración es un paso crucial durante la fecundación ya que los espermatozoides que no son capaces de reconocer y unirse a las glicoproteínas de la ZP no fecundarán el ovocito. La unión a la ZP involucra proteínas de la membrana acrosomal interna, las que se unen específicamente a la glicoproteína ZPII (Romar Andrés, 2001).

Figura 14. Representación esquemática de la composición de la ZP en varios mamíferos (Gupta y Bhandari, 2011).
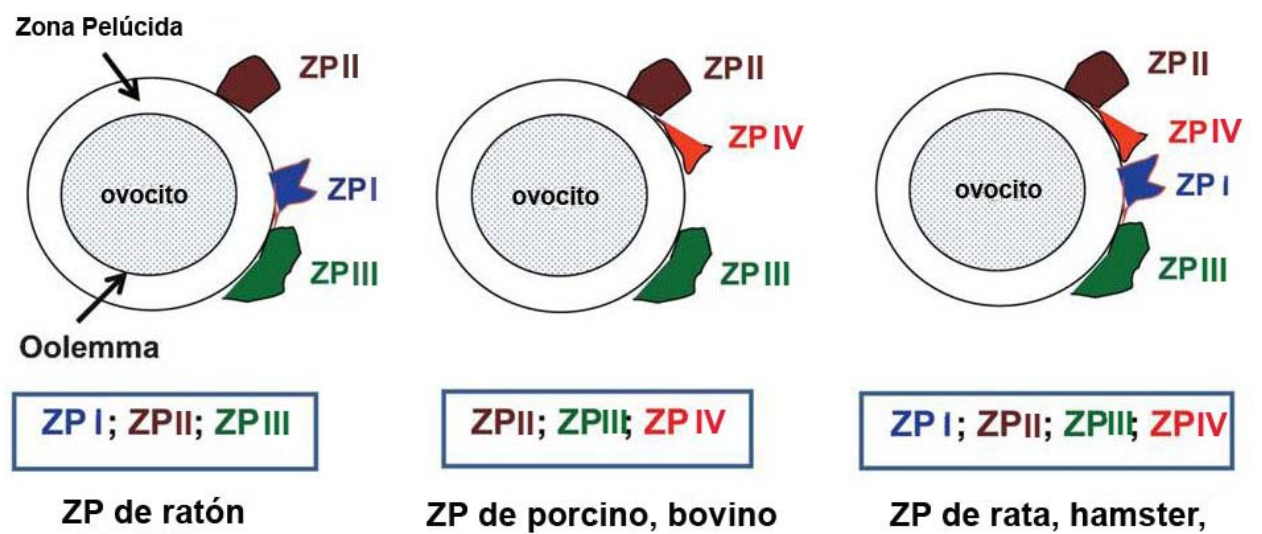

ZPII; ZPII; ZPIV

ZP de porcino, bovino y canino
ZPI; ZPII; ZPII; ZPIV

ZP de rata, hamster, mono y humano

La matriz de la zona pelúcida está compuesta por tres o cuatro glicoproteínas. En el ratón la constituye la ZP I (azul), ZP II (marron) y ZP III (verde). En rata, hámster, mono y humano la matriz posee ZP I, ZP II, ZP III y ZP IV (rojo). En bovino, porcino y canino la matriz contiene ZP IV en reemplazo de ZP I. ZP: zona pelúcida.

\subsubsection{Fusión de las gametas in vitro}

Luego de la reacción acrosómica el espermatozoide pierde el contenido acrosomal quedando expuesta la membrana acrosomal interna. Ésta se encuentra fusionada a la 
membrana plasmática de la región posacrosomal de la cabeza del espermatozoide, formando el segmento ecuatorial. Es por este segmento, donde comienza la fusión de las membranas plasmáticas entre ambas gametas (Elder y Dale, 2011).

Una vez atravesada la ZP el espermatozoide alcanza el espacio perivitelino. La penetración de la ZP es el resultado de la acción coordinada de las enzimas acrosomales liberadas en la RA y la fuerza de empuje desarrollada por el movimiento del espermatozoide, que agita la cola de lado a lado y la cabeza de adelante a atrás (Martínez Madrid, 2002). Una vez en el espacio perivitelino la membrana plasmática del espermatozoide se une al oolema en sus múltiples microvellosidades. La fusión, que primeramente involucra solo a la cabeza del espermatozoide, en algunos mamíferos continúa hasta la incorporación del cuerpo completo del espermatozoide dentro del citoplasma del ovocito (Elder y Dale, 2011). Las mitocondrias presentes en la cola del espermatozoide son degradadas y sólo las mitocondrias maternas pasarán a la siguiente generación (Martínez Madrid, 2002).

En este momento los gránulos corticales se fusionan con la membrana plasmática del ovocito liberando su contenido dentro del espacio perivitelino. Las enzimas hidrolíticas y glicoproteínas liberadas modifican las características fisicoquímicas de la ZP evitando la entrada de nuevos espermatozoides y por lo tanto la polispermia. A este proceso se lo conoce como reacción cortical o de zona. En el ratón, la acción de proteinasas o glicosidasas de los gránulos resultan en la hidrólisis de la glicoproteína ZP III, lo que previene la interacción con nuevos espermatozoides. Al mismo tiempo, la membrana plasmática del cigoto se convierte en un mosaico formado por las membranas de los gránulos corticales y la membrana plasmática original. Además, se genera un fuerte endurecimiento de la zona pelúcida. (Martínez Madrid, 2002; Sun y Nagai, 2003; Elder y Dale, 2011) (Figura 15). 
Figura 15. Diagrama donde se muestran todos los pasos de la fusión del espermatozoide con el ovocito (Yanagimachi, 1994).
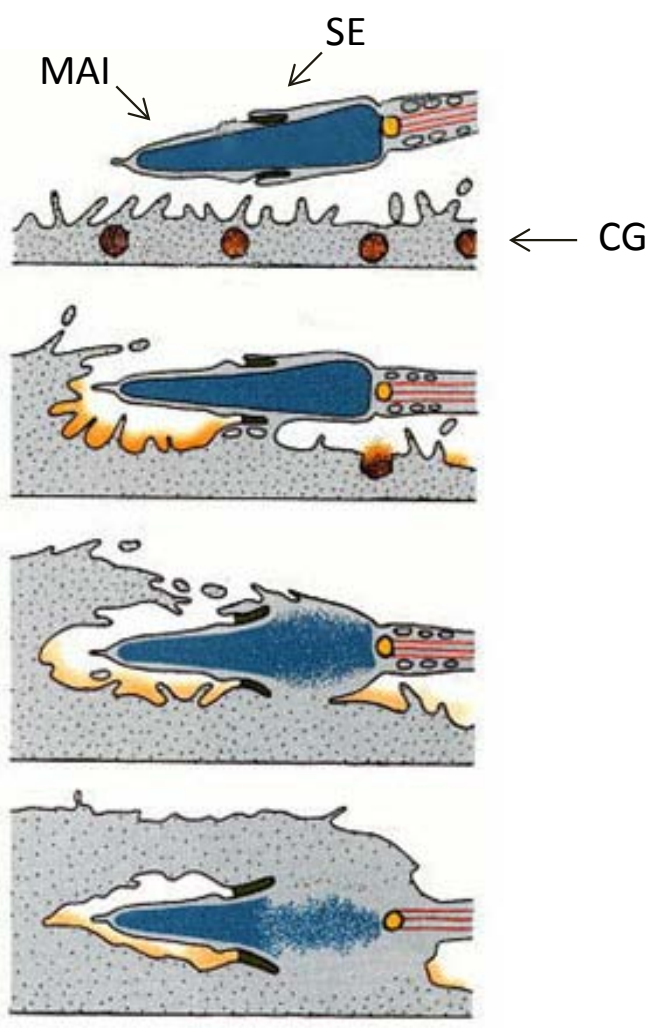

(CG) gránulos corticales, (MAI) membrana acrosomal interna y (SE) segmento ecuatorial.

Podríamos resumir los principales eventos que sufre el espermatozoide durante la fecundación in vitro en la Figura 16.

La fecundación y la consecuente formación del cigoto marcan el comienzo del período de desarrollo preimplantacional que finaliza con la implantación del embrión en el útero. 
Figura 16. Secuencia de los principales eventos que sufre el espermatozoide hasta su fusión con el ovocito.

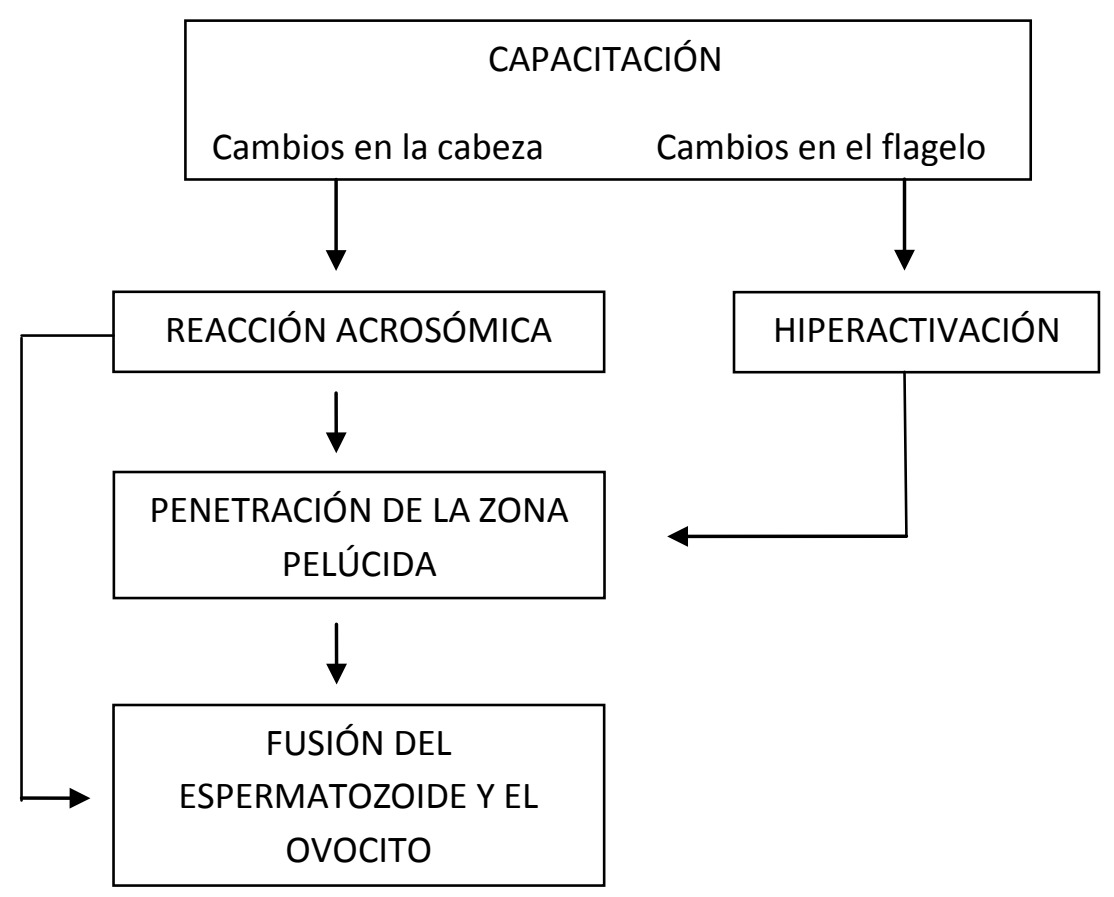

\subsubsection{Desarrollo de embriones in vitro}

Luego de la fecundación, la membrana nuclear del espermatozoide se rompe, se produce la sustitución de protaminas por histonas, la cromatina se descondensa y se forma una nueva membrana nuclear, dando lugar al pronúcleo masculino (PNM). Al mismo tiempo el ovocito finaliza la meiosis II, se libera el segundo corpúsculo polar, el genoma materno también se descondensa, se forma la membrana nuclear y queda constituido el pronúcleo femenino (PNF) (Martínez Madrid, 2002; Sun y Nagai, 2003). Luego de la formación de los PNM y PNF estos migran gradualmente hacia el centro del ovocito donde se aproximan el uno con el otro. Durante 
este trayecto replican su ADN, se desintegran sus membranas nucleares y sus cromosomas se asocian preparándose para la primera división mitótica (Martínez Madrid, 2002; Elder y Dale, 2011). La fusión de los pronúcleos masculino y femenino se considera el fin del proceso de fecundación y el inicio del desarrollo embrionario. En los mamíferos este proceso dura aproximadamente 12 horas (Martínez Madrid, 2002). Posteriormente, se forma el primer surco de segmentación, seguido de una serie de divisiones mitóticas que culminarán con la formación del blastocisto.

El primer clivaje separa a la cigota en 2 blastómeros iguales o casi iguales e independientemente de las especies, se realiza entre las 11 y 20 hs posfecundación. Estas células luego se dividen secuencialmente de forma paralela (meridional) u ortogonal (ecuatorial) al plano de clivaje inicial para generar un embrión de 4 blastómeros (Figura 17). Este desarrollo asincrónico de los estadios más tempranos es propio de los mamíferos. Por lo tanto, estos embriones no multiplican sus células exponencialmente desde los estadios de 2 a 4 y de 4 a 8 células, sino que es posible ver en ellos, números impares de blastómeros (Eynard y col., 2008; Li y col., 2010).

A partir del estadio de 8 células en el ratón, el espacio intercelular comienza a reducirse, los blastómeros se agrupan y forman una esfera compacta de células. Esta organización es estabilizada por uniones estrechas que se forman entre las células exteriores de la esfera y que sellan su interior. Las células dentro de la esfera forman uniones nexo, permitiendo de este modo el paso de pequeñas moléculas e iones entre ellas. Este proceso recibe el nombre de "compactación" y da origen al estadio de mórula que en el ratón se hace evidente a partir de las 8 células, en el bovino a partir de las 32 células y, en el ovino entre las 32 y las 64 células (Gilbert, 2005b; Eynard y col., 2008). 
Figura 17.Clivajes embrionarios iniciales en ratón (Li y col., 2010).

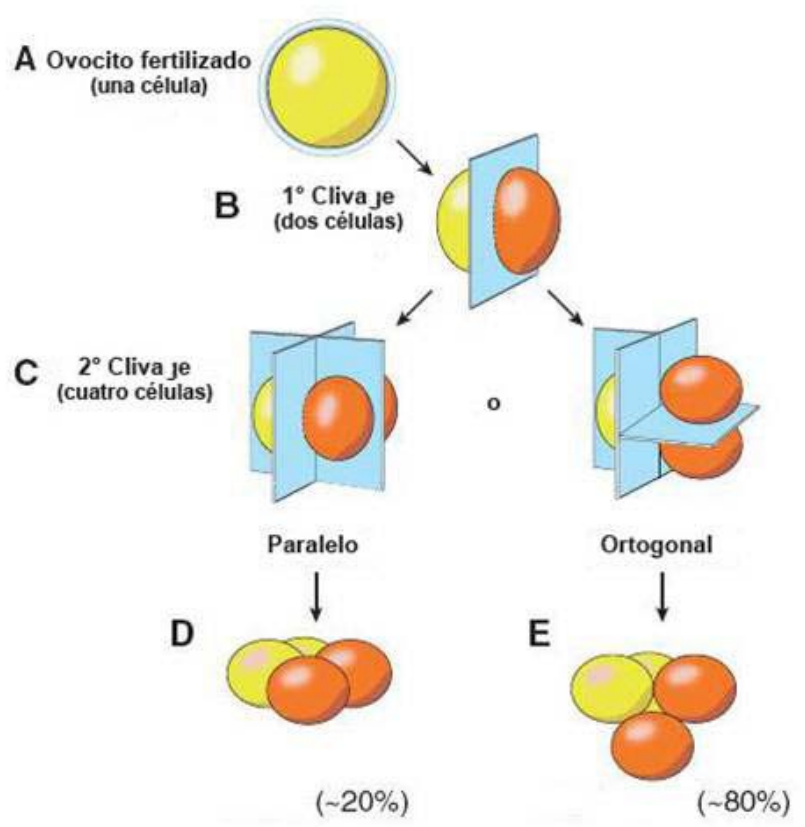

A y B: El primer clivaje del ovocito fertilizado forma un embrión simétrico de 2 células, en el cual cada blastómero (amarillo y naranja) permanece totipotencial. C: El segundo clivaje ocurre secuencialmente y puede ser paralelo al primer clivaje (izquierda) $\mathrm{u}$ ortogonal (derecha). D y E: Aproximadamente en el $20 \%$ de los casos el embrión de 4 células es producto de la división paralela, mientras que en el $80 \%$ de estos se forma a partir de una división ortogonal.

A partir del estadio de 16 células en hamster y cerdo, 32 células en ratón, 64 células en oveja y humano y 80 a 100 células en bovino, los blastómeros periféricos comienzan a liberar sodio hacia el interior del embrión lo que arrastra agua para mantener la isotonicidad dando lugar a la formación del blastocele y por lo tanto al estadio embrionario de blastocisto. Rodeando la nueva cavidad se encuentra una capa de células planas Ilamada trofoblasto. En uno de los polos (polo embrionario) y haciendo protrusión en la cavidad blastocélica se produce una acumulación de células que se denomina macizo celular interno y que dará origen al embrión con todos los órganos del nuevo individuo, mientras que el trofoblasto formará parte de la futura placenta. Las células del trofoblasto secretan estripsina (una proteasa parecida a la tripsina) que produce una ruptura de la matriz fibrilar de la zona pelúcida permitiendo que el 
blastocisto se libere (eclosione) y se implante en la pared uterina (Gilbert, 2005b; Eynard y col., 2008).

Figura 18. Estadios de desarrollo preimplantacional en ratón (Yamanaka y col., 2006).

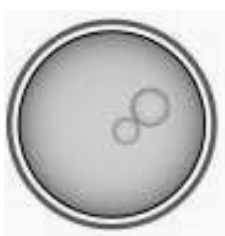

Ovocito Fertilizado

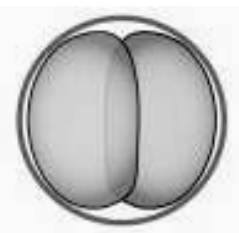

2 Células

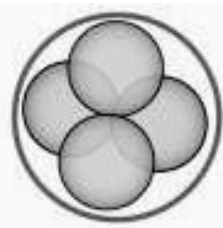

4 Células

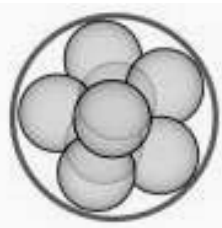

8 Células

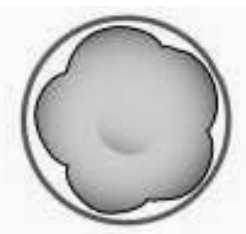

$8 \mathrm{Cs}$. Compactadas Mórula temprana

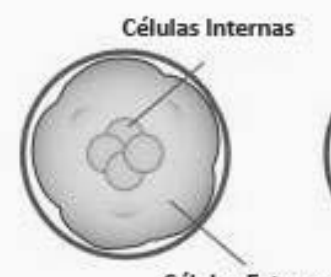

Células Externas

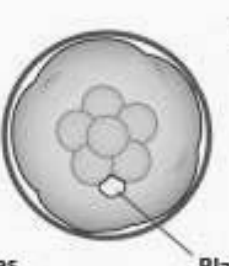

Blastocele

TE

16-32 Células

Mórula Tardia Cavitaria

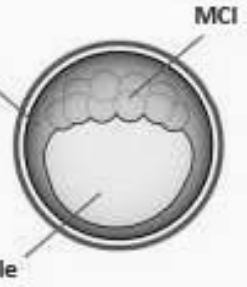

Blastocisto Temprano

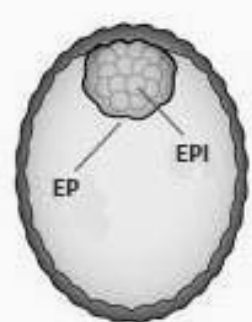

Blastocisto tardio

Luego de tres clivajes se alcanza el estadio embrionario de 8 células. Las células embrionarias de los estadios de 8 células 0 mórula temprana se compactan unas con otras hasta que sus bordes celulares se vuelven invisibles. Las subsecuentes divisiones conducen al estadio de mórula tardía, donde se establecen dos tipos celulares diferentes: células internas y externas. Durante el estadio de mórula tardía aparece el blastocele. La expansión de esta cavidad continúa a través de los estadios de blastocisto temprano y tardío. En el estadio de blastocisto aparecen dos linajes celulares bien distintos: el trofoectodermo (TE) (derivado de las células externas) y el macizo celular interno $(\mathrm{MCl})$ (derivado de las células internas). El TE también se encuentra presente en el blastocisto tardío, pero el $\mathrm{MCl}$ se divide en el epiblasto (EPI) y el endodermo primitivo (EP).

Durante los primeros estadios de desarrollo, las células del embrión son totipotenciales, es decir, que conservan el potencial para diferenciarse en cualquier tipo celular. Por ejemplo, si se separan los blastómeros de un embrión de ratón en el estadio de 2 a 8 células o de 4 células 
en el bovino, cada uno es capaz de dar origen a un blastocisto. La ablación de blastómeros durante estos estadios no afecta al desarrollo de un feto normal (Yamanaka y col., 2006).

Aspectos bioquímicos y moleculares del embrión pre-implantacional: Activación del genoma embrionario.

Durante el crecimiento intraovárico del ovocito el genoma materno es transcripto y la transcripción es almacenada. La mayoría de las transcripciones son transformadas directamente a proteínas, sin embargo, algunas permanecen silenciadas y comienzan a activarse luego de la ovogénesis producto de una cuidadosa poliadenilación. Durante la maduración meiótica (12 horas antes de la ovulación en el ratón) los ovocitos se vuelven transcripcionalmente quiescentes y la mayoría de su ARN poliadenilado desaparece. Muchas de las proteínas maternas también son degradadas tempranamente en el desarrollo. Probablemente, sin la degradación del ARN y de las proteínas maternas la programación del desarrollo embrionario no podría ser activada. Sin embargo, esta degradación debe ser lo suficientemente selectiva como para mantener factores maternos que aseguren niveles adecuados de proteínas hasta que el genoma del embrión sea activado (Minami y col., 2007; Li y col., 2010). El ARN almacenado en el ovocito de ratón consiste en un $60 \%$ de ARN ribosomal, un $25 \%$ ARN de transferencia y un $15 \%$ a ARN poly A. Cerca del $90 \%$ de este stock de ARN será degradado en el estadio embrionario de 2 células (Edwards y Beard, 1997; Minami y col., 2007). Los eventos de síntesis celular que ocurren inmediatamente luego de la fecundación dependen de lo que se denomina "herencia materna" hasta tanto se active el genoma del embrión, es decir, del nuevo individuo.

La transcripción del genoma embrionario en ratones se activa entre la fecundación y la segmentación. Una primera activación menor del genoma embrionario ocurre en el pronúcleo 
masculino del cigoto, mientras que dos ondas mayores de activación se observan en el embrión de 2 células y durante la transición de los estadios de 4 a 8 células (Figura 19) (Li y col., 2010). Si bien, la transcripción del nuevo genoma se activa en estadios de desarrollo muy tempranos, no corresponde al mismo estadio de desarrollo en todas las especies. A diferencia de lo que ocurre en el ratón, el genoma embrionario en el cerdo, bovino y ovino se activa en los estadios de 4, 8 y 8 a 16 células respectivamente (Gil Villa y col., 2007). Luego de la activación del genoma embrionario, los factores maternos almacenados pierden relevancia para el desarrollo preimplantancional por lo que son degradados y rápidamente reemplazados por los sintetizados a partir del nuevo genoma (Minami y col., 2007; Li y col., 2010).

Figura 19. Desarrollo preimplantacional en ratón (Li y col., 2010).

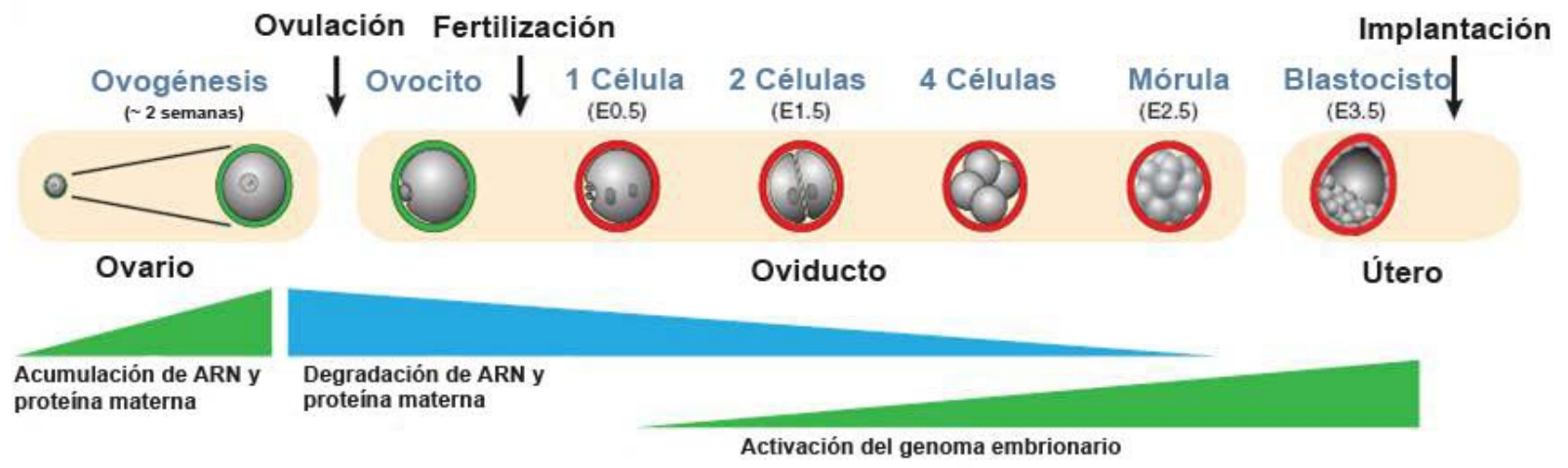

Ovogénesis y desarrollo temprano. El ARN y las proteínas maternas se acumulan dentro del ovocito durante una fase de crecimiento de una duración aproximada de 2 semanas. Muchas de estas sustancias son degradadas durante la maduración meiótica y la ovulación. La zona pelúcida (verde) que rodea al ovocito en crecimiento y al ovocito ovulado, se modificada luego de la fecundación (rojo) para prevenir la polispermia y proteger al embrión cuando atraviesa el oviducto. El embrión del día 0,5 (E0.5) posee 1 célula. En el embrión de 2 células (E1.5) se activa el genoma embrionario. En el día 2,5 (E2.5) el embrión sufre la compactación que lo transformará en mórula. En el día 3,5 (E3.5) el embrión alcanza el estadio de blastocisto y se implanta en la pared uterina en el día 4,2.

El desarrollo embrionario preimplantacional está regulado epigenéticamente. La epigenética se refiere al conjunto de mecanismos y fenómenos que pueden causar cambios en 
el fenotipo de una célula o de un organismo sin alterar su secuencia de ADN. La reprogramación epigenética involucra la metilación del ADN, modificaciones de las histonas, remodelación de la cromatina, y la modulación de la traducción y de la estabilidad del ARN (Vasalli y col., 1989; Shi y Wu, 2009; Li y col., 2010).

La metilación del ADN es una modificación química covalente en el que un grupo metilo es transferido a las citosinas de sus nucleótidos. La metilación del ADN es un importante evento epigenético, el cual interviene en la regulación de la estructura de la cromatina y en la expresión de genes en muchos de los procesos del desarrollo. Durante las etapas preimplantacionales de la embriogénesis, la metilación del ADN experimenta cambios dinámicos. Esta metilación que se presenta de forma activa en el pronúcleo masculino, se desarrolla pasivamente durante las etapas de división más tardías y es probablemente la encargada de silenciar los genes relacionados a la totipotencialidad (Shi y Wu, 2009; Li y col., 2010).

La Modificación de las histonas, al igual que la metilación del ADN, es una modificación covalente que interviene en la regulación de la expresión génica. Este fenómeno incluye la acetilación, metilación y fosforilación (entre otros) de las histonas. Estos cambios covalentes actúan como interruptores de la expresión génica, la cual puede ser controlada con precisión según las circunstancias (Shi y Wu, 2009; Li y col., 2010).

Las histonas son proteínas básicas de bajo peso molecular. Existen cinco tipos principales: la histona $\mathrm{H} 1$ y las histonas $\mathrm{H} 2 \mathrm{~A}, \mathrm{H} 2 \mathrm{~B}, \mathrm{H} 3$ y H4. Estas últimas constituyen bloques de construcción para los nucleosomas, cada uno compuesto por ocho proteínas histonas (dos histonas $\mathrm{H} 2 \mathrm{~A}, \mathrm{H} 2 \mathrm{~B}, \mathrm{H} 3$ y $\mathrm{H} 4$ ) para formar un octámero alrededor del cual se envuelve la cadena de ADN. La histona $\mathrm{H} 1$, por otro lado, se coloca como pieza de cierre en cada nucleosoma y al mismo tiempo toma contacto con las agrupaciones vecinas. Se han encontrado 
en mamíferos un conjunto de variantes de histonas (en diferentes estadios de desarrollo preimplantacional) que conducen a la diferenciación de la cromatina. Este cambio en el nivel más básico de empaquetamiento del ADN facilita o dificulta la transcripción de los diferente genes (Shi y Wu, 2009; Li y col., 2010).

Un mecanismo rápido y eficaz para regular la expresión génica consiste en la modulación de la traducción y de la estabilidad del ARN. Los ovocitos de rana y ratón almacenan distintos tipos de ARNm en su citoplasma, pero traducen esos ARNm a diferentes tiempos durante la maduración (Bachvarova y col., 1985). Diversos estudio han demostrado que la poliadenilación es crítica para la traducción del ARNm del ovocito y que esta poliadenilación es regulada por la región 3' no traducida (UTR 3'). La UTR 3' puede regular la eficiencia de traducción del ARNm del ovocito controlando el tamaño de la cola de Poli A. Los ARNm que son almacenados por el ovocito para su traducción en la maduración meiótica justo antes de la ovulación o en la fecundación, tienden a perder parte de la cola de Poli A cuando entran al citoplasma. En la maduración meiótica, aquellos ARNm que han sido activamente traducidos pierden su cola de Poli A y funcionan por un corto tiempo. Por el contrario, los ARNm pobremente adenilados que han sido almacenados, incrementan rápidamente el número de residuos de poli $\mathrm{A}$ y son traducidos en proteínas (Vasalli y col., 1989). En el ratón, luego de la fecundación, el contenido ARN Poli A decae un 50\% dentro de las primeras 24 hs lo que puede deberse a desadenilación y/o degradación de las moléculas (Paynton y col., 1988; Li y col., 2010).

La búsqueda de sistemas de fecundación y desarrollo embrionario in vitro para cada especie aportó gran cantidad de información sobre el rol de diversos compuestos que afectan la capacitación del espermatozoide y la fecundación del ovocito maduro. Por lo tanto, se debe tener en cuenta que no existe un medio de fecundación único, ya que existen requerimientos particulares que difieren de una especie a otra. 
Figura 20. Cambios moleculares al inicio del desarrollo (Li y col., 2010)

A

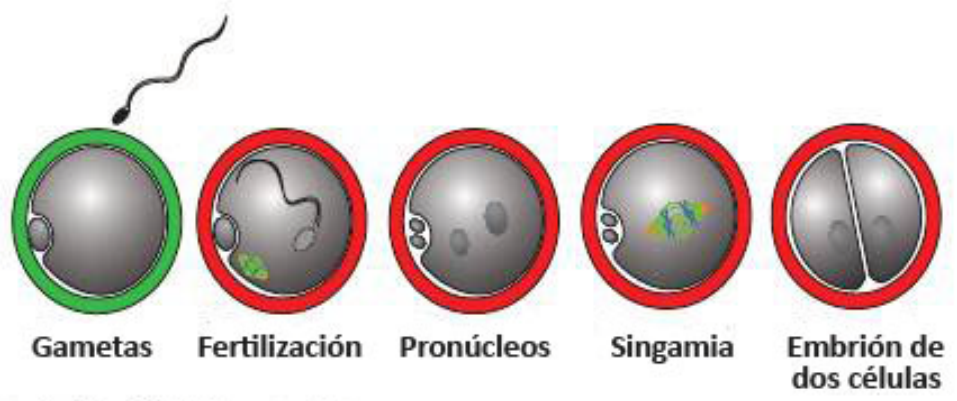

B Degradación de ARN y proteinas

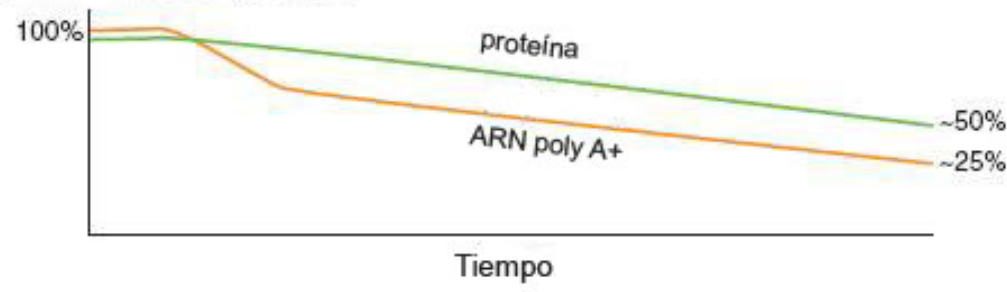

\section{Metilación del ADN}

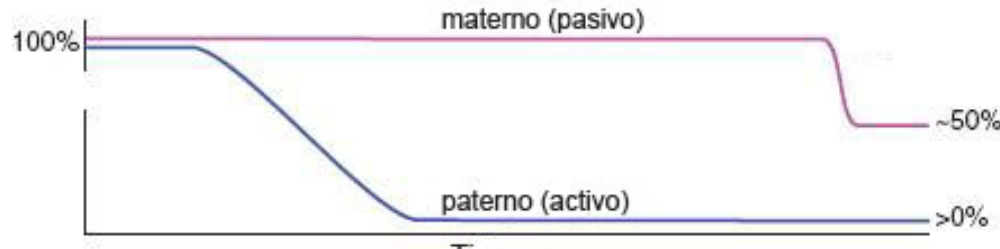

Tiempo

\section{Transcripción embrionaria}

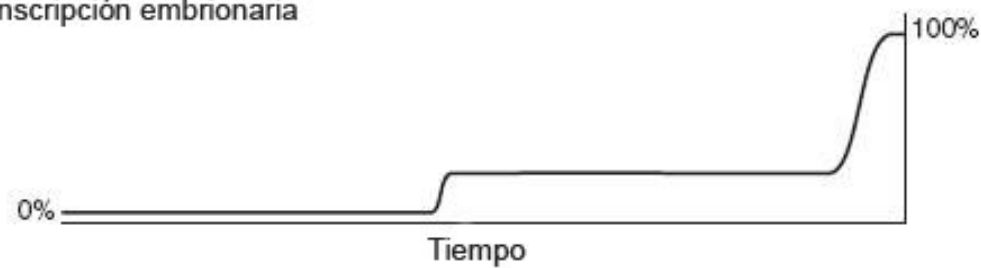

A: Comienzo del desarrollo embrionario en ratón. Las gametas transcripcionalmente inertes se fusionan durante la fecundación y el espermatozoide completo se introduce dentro del citoplasma del ovocito. El núcleo del espermatozoide se descondensa y se vuelve a empaquetar con las histonas almacenadas en el ovocito formando el pronúcleo masculino. El ovocito completa su segunda división meiótica y forma el pronúcleo femenino. Luego de la singamia y de la citoquinesis queda establecido el embrión de dos células. B: Degradación del ARN y de las proteínas maternas. Para alcanzar el estadio de clivaje es necesario el almacenamiento de ARN y proteínas maternas. Sin embargo, estos reservorios son luego degradados, quedando en el embrión de 2 células, sólo un $25 \%$ del ARN poli A y un $50 \%$ de las proteínas maternas. C: Desmetilación del genoma embrionario. Luego de la fecundación y antes de la replicación del ADN y la formación del pronúcleo, el genoma masculino es activamente desmetilado. Por el contrario, el genoma femenino sufre una desmetilación pasiva con cada división celular, resultando en un embrión con su ADN hipometilado. D: Activación génica del embrión. Luego de una activación transcripcional leve durante el estadio de pronúcleos (más en el masculino que en el femenino) la transcripción embrionaria aumenta intensamente en el embrión de dos células. 


\subsection{El Zinc}

\subsubsection{Introducción}

El Zinc (Zn) es un microelemento cuya función esencial en los organismos vivos se conoce desde 1869 (McCall y col., 2000). En 1926, se lo asoció a la viabilidad de las plantas superiores (Torres Acosta y Bahr Valcarcel, 2004) y en 1934 (Todd y col., 1934) demostraron su vital importancia en estudios de crecimiento realizados en ratas. Este mineral interviene en una amplia variedad de procesos celulares como la proliferación, la función inmune y la defensa antioxidante (Bray y Bettger, 1990; Powell, 2000). Además, participa en la estabilidad y regulación génica, forma parte de más de 3000 factores de transcripción, de más de 300 enzimas incluyendo la cobre/zinc superóxido dismutasa (Cu/Zn-SOD) y de varias proteínas involucradas en la reparación del ADN (Prasad, 1998; Dreosti, 2001; Prasad, 2003; Prasad y Kucuk, 2002). El Zn se encuentra presente en casi todas las células animales, sin embargo, las concentraciones presentes en el músculo esquelético y en el hueso representan el 90 \% del Zn total del individuo (Cousins, 1999). El Zn es considerado el oligoelemento intracelular más abundante, formando parte de las metaloproteínas dependientes de Zn que se encuentran en el interior del citoplasma, núcleo y organelas incluyendo el retículo endoplasmático, aparato de Golgi, vesículas secretoras y las mitocondrias (David, 2006).

\subsubsection{Fuentes de zinc para el bovino}

En pasturas y cereales la concentración de Zn puede ser muy variable [7 a 100 mg/Kg de materia seca (MS)]. Por lo general, estos valores se encuentran entre los 25 y $50 \mathrm{mg} / \mathrm{Kg}$ de MS, con un valor promedio de $36 \mathrm{mg} / \mathrm{Kg}$ de MS (Rosa y col., 2008). Se sabe que la concentración de este mineral en pasturas y cereales se encuentra directamente relacionada con el estatus de 
Zn presente en el suelo. Por lo tanto, suelos que presenten bajos niveles de Zn establecerán en consecuencia zonas de carencia. En el caso de la leche, único alimento del lactante, contiene entre 3 y $5 \mathrm{mg}$ de Zn/litro, alcanzando en el calostro una concentración de 14 mg/l (Underwood y Suttle, 1999; Rosa y col., 2008).

\subsubsection{Metabolismo del zinc}

Absorción y Transporte

La absorción de Zn ocurre principalmente en el intestino delgado y se encuentra en estrecha relación con las necesidades del organismo (Miller y col., 1991; Underwood y Suttle, 1999; Spears, 2003). En rumiantes, a diferencia del resto de los mamíferos, el coeficiente de absorción del Zn es elevado con porcentajes de absorción de Zn que se ubican entre el 35 \% y el $70 \%$. Esto se debe a la capacidad que posee la flora microbiana del rumen para inactivar el fitato, agente quelante que se une a ciertos cationes como el $\mathrm{Ca}^{++}$y el $\mathrm{Zn}^{++}$, produciendo la precipitación de los mismos al formar con ellos complejos insolubles (Gifford y Clydesdale, 1990).

Existen varios factores que pueden influir en la absorción de este microelemento. El porcentaje de Zn dietario absorbido disminuye conforme aumenta la presencia de este mineral en la dieta (Sandstrom y Cederblad 1980). Otra fuente de variación está relacionada con el modo de presentación del Zn. Kincaid y colaboradores (1997) demostraron que la suplementación con Zn-lisina y Zn-metionina (formas orgánicas) genera mayor disponibilidad de Zn que el óxido de Zn (forma inorgánica). Por otro lado, Cao y colaboradores (2000) al igual que Wright y Spears (2004) no encontraron diferencias al utilizar sulfato de Zn o distintas fuentes orgánicas. En consecuencia, existen contradicciones en cuanto a los resultados obtenidos con la utilización de fuentes orgánicas o inorgánicas (Malcolm-Callis y col., 2000; Spears y Kegle, 
2002; Nunnery y col., 2007). Rosa y colaboradores (2008) sugieren que esto podría deberse a diferencias en el metabolismo ruminal y tisular de estas fuentes, más que en variaciones de su coeficiente de absorción.

La absorción entérica de Zn ocurre mediante un proceso no saturable (difusión pasiva) que no se encuentra afectado por la concentración de Zn presente en la dieta y uno saturable mediado por transportadores específicos para este mineral llamados ZIP4 (Wang y col., 2002; Tapiero y Tew, 2003; Mafra y Cozzolino, 2004). La restricción dietética de Zn produce en el enterocito de ratón un aumento en la expresión de esta proteína transportadora (McMahon y Cousins, 1998). Cuando las concentraciones del Zn dietario se encuentran elevadas, la expresión de ZIP4 se halla reducida y en consecuencia su presencia en la membrana plasmática apical también lo está.

El Zn en estado libre dentro del enterocito es transportado al sistema porta a través de un transportador específico llamado ZnT1 (Cousins y col., 2006). Una vez en sangre el Zn viaja unido principalmente a la albúmina (84\%) y en menor medida a $\alpha 2$-macroglobulina (15\%) y a aminoácidos (1\%) (Tapiero y Tew, 2003). La concentración plasmática de Zn es de aproximadamente $1 \mu \mathrm{g} / \mathrm{ml}$ y a pesar de representar sólo el 0,1 \% del contenido corporal es la principal fuente de este mineral para todas las células (Mafra y Cozzolino, 2004).

La captación celular de Zn se realiza por múltiples mecanismos, entre los que se encuentran: cotransporte unido a aminoácidos (cisteína o histidina), unión al receptor de la transferrina y más recientemente estudiados, por unión a las proteínas transportadoras ZIP. Los transportadores ZIP son proteínas transmembrana cuya función consiste en aumentar la concentración de Zn intracelular al mediar el flujo de entrada del Zn extracelular hacia la célula, o al liberar el Zn de las vesículas intracelulares hacía el citoplasma. Por otro lado, existe otro 
grupo de proteínas transmembrana, llamadas ZnT, que tienen por objetivo disminuir la concentración intracitoplasmática de este mineral realizando la función opuesta (Cousins y col., 2006. Figura 21).

La homeostasis intracitoplasmática de $\mathrm{Zn}$ también se encuentra regulada por las metalotioneínas (MT). Las MT son un grupo de proteínas de bajo peso molecular (6000-7000 kDa) que contienen 60-68 residuos de aminoácidos, de los cuales 25 - 30 \% son cisteína (Powell, 2000). Cada molécula de MT contiene 7 átomos de Zn que pueden ser liberados, a pesar de su elevada estabilidad termodinámica, de acuerdo a la demanda celular (Maret, 2000). Este hecho, sumado a la capacidad de la MT de atravesar diferentes compartimientos celulares le otorga a esta proteína un rol esencial en el metabolismo del Zn (Maret, 2003). La MT permite la amortiguación de la concentración intracitoplasmática de Zn de una manera controlada, tomando o cediendo átomos de Zn de acuerdo a las circunstancias (Tapiero y Tew, 2003). Además, participa en la traslocación del Zn entre los diferentes compartimentos celulares (Maret, 2003).

\subsubsection{Depósito orgánico}

La capacidad de almacenamiento de $\mathrm{Zn}$ por parte del organismo resulta poco desarrollada. A pesar de la ausencia de reservorios específicos para Zn, cantidades significativas de este mineral pueden ser redistribuidas a partir de los tejidos muscular y óseo (Underwood y Suttle, 1999). 
Figura 21. Cambios en la expresión del transportador de zinc en murinos en respuesta al contenido de zinc en la dieta (Cousins y col., 2006).

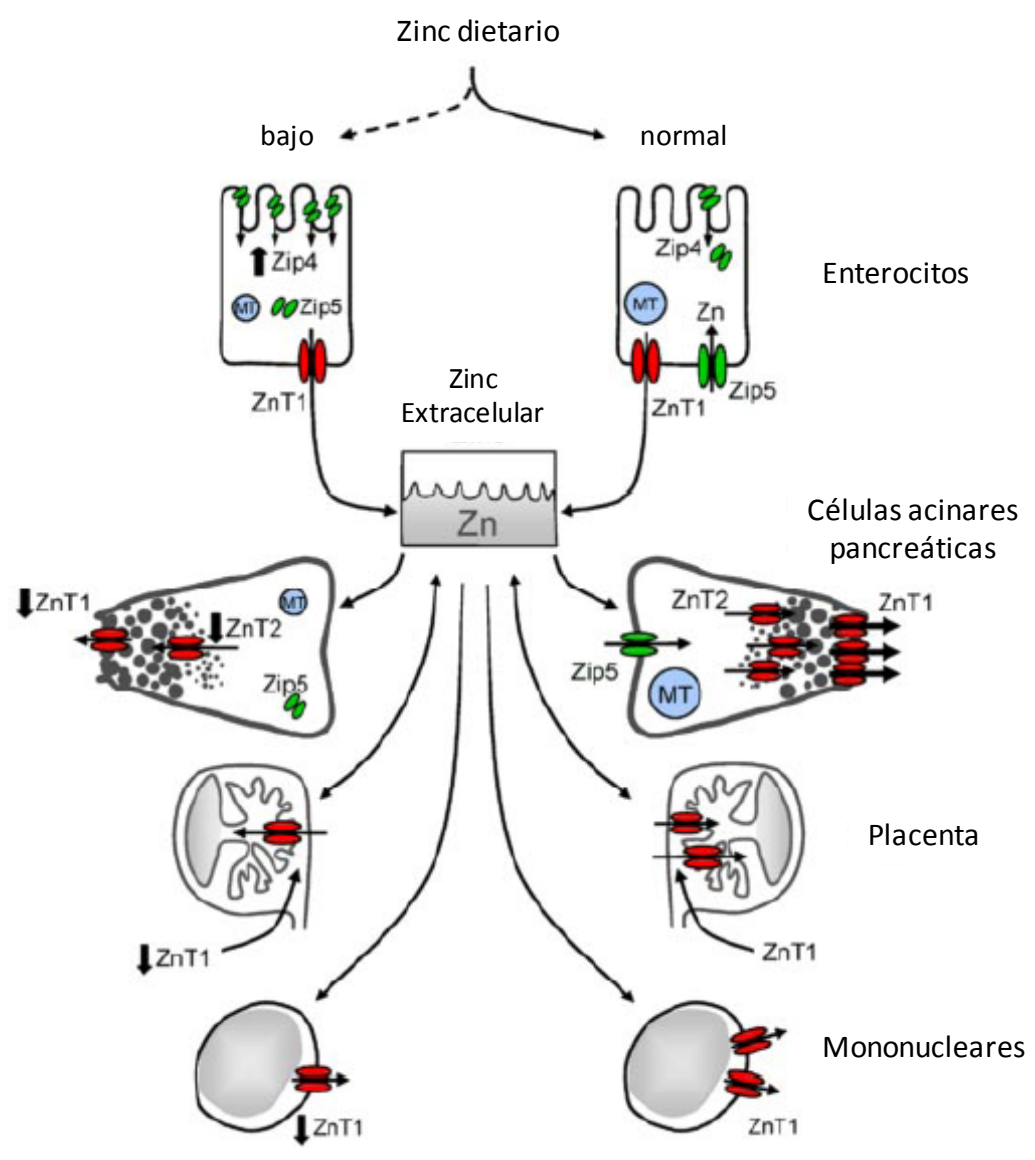

Cuando el Zn en la dieta es bajo la expresión de ZIP4 en enterocitos aumenta, con más ZIP4 localizado en la membrana apical provocando mayor incorporación de Zn a partir de la dieta. Por otro lado, cuando el suministro de Zn es adecuado, los enterocitos tienen una mayor expresión de metalotioneína (MT) y de ZIP5 que se localiza en la membrana basolateral. En dietas bajas en zinc, disminuye la expresión de ZnT1 y ZnT2 en las células acinares del páncreas y ocurre la internalización de ZIP5 y reducción de la MT. La baja ingesta de zinc también disminuye la expresión de ZnT1 en la placenta (saco vitelino visceral) y en células mononucleares de la sangre periférica. Estos eventos reflejan un intento de restaurar la homeostasis de zinc durante la restricción de este mineral en la dieta a través de una absorción intestinal incrementada, con simultánea reducción en la pérdida a partir de las secreciones pancreáticas e intestinales, junto con la conservación de zinc por parte de células con alta rotación, como las del sistema inmunológico.

\subsubsection{Pérdidas endógenas}

Existen tres vías de excreción del Zn endógeno: por vía digestiva, por vía renal y por la leche (Rosa y col., 2008). La excreción de Zn en rumiantes, al igual que lo que ocurre en otros 
animales, se produce fundamentalmente por las heces. El Zn fecal lo constituye aquel $\mathrm{Zn}$ que no fue absorbido en la dieta y el que pasó a la luz del intestino a través de las secreciones exocrinas del páncreas, bilis, células descamadas, mucus y las secreciones de la mucosa. Los mecanismos implicados en la regulación de las pérdidas endógenas intestinales de Zn no han sido aún identificados de manera satisfactoria. Sin embargo, se han descripto cambios homeostáticos en la absorción y en la pérdida neta a nivel intestinal en respuesta a un aumento o disminución en el suministro de Zn en la dieta o de acuerdo a las necesidades del propio individuo (Miller, 1969; Taylor y col., 1991). Por lo tanto, el tracto gastrointestinal representa el mayor sitio de regulación de la homeostasis de Zn (Tapiero y Tew, 2003) (Figura 22). Las pérdidas endógenas por vía renal tiene una importancia secundaria y la pérdida por leche varía con el aporte de Zn en la dieta (Miller y Stake, 1974; Nockels y col., 1993; Rosa y col., 2008).

\subsubsection{Requerimientos}

Los requerimientos de Zn por parte del animal varían en relación a la especie, raza, edad, estado fisiológico y la composición de la dieta entre otros factores (Underwood y Suttle, 1999). Estas múltiples variables sumadas al poco conocimiento sobre el metabolismo del Zn, hacen de la interpretación de los requerimientos una tarea difícil de resolver. Se han desarrollado diversos trabajos tendientes a caracterizar las necesidades de este mineral en el bovino (Neathery y col. 1973; Engle y col 1997; Underwood y Suttle, 1999). Estos trabajos sugieren que los requerimientos de Zn para el desempeño óptimo del crecimiento y la fertilidad podrían superar los $20 \mathrm{mg} \mathrm{Zn/} \mathrm{kg} \mathrm{DM} \mathrm{consumida.} \mathrm{El} \mathrm{Consejo} \mathrm{Nacional} \mathrm{de} \mathrm{Investigaciones} \mathrm{(National} \mathrm{Research}$ Council, NRC-USA) en el año 2000, utilizando el método factorial desarrollado por el Consejo de Investigaciones Agrícola (Agriculture Research Council, ARC-USA) en 1980, propone para bovinos de carne y leche un requerimiento de $\mathrm{Zn}$ de 30 ppm (MS) en la dieta. Demanda que en 
vaca en lactancia se incrementa a razón de 24 mg de Zn por kg de leche producido (NRC-USA, 2000; Rosa y col., 2008).

Figura 22. Regulación entérica de Zinc (Underwood y Suttle, 1999).

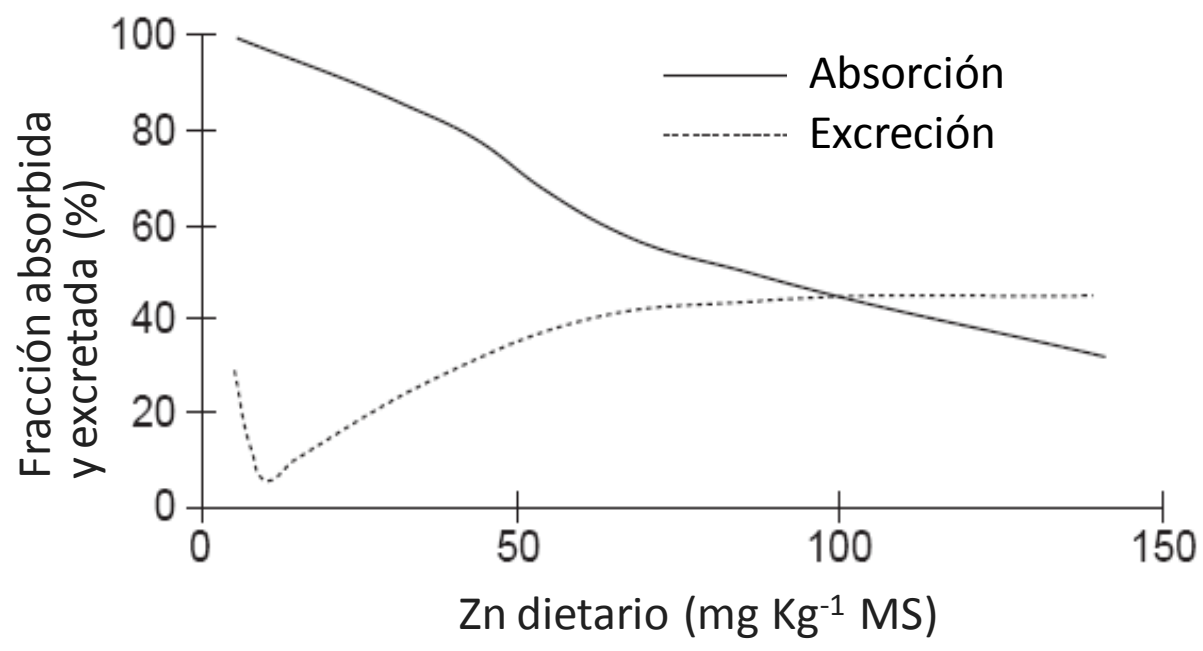

Los animales ajustan el aumento de la ingesta de Zn reduciendo la fracción de Zn que es absorbido y excretando una mayor proporción del Zn a través de las heces. (MS= materia seca).

\subsubsection{Funciones del zinc}

El Zn participa en múltiples y variados procesos biológicos que lo involucran en su forma iónica o como parte estructural y/o funcional de una gran variedad de proteínas. De acuerdo a la ubicación del Zn en estas metaloproteínas este microelemento puede actuar como catalizador (carboxipeptidasa A), cocatalizador (fosfatasa alcalina, fosfolipasa C, nucleasa P1 y leucina aminopeptidasa) o desempeñando una función estructural (Cu/Zn-SOD y "dedos de Zinc"). Cuando el Zn se encuentra en el sitio catalítico, el ion de Zn participa directamente en el proceso de formación o ruptura de uniones moleculares. Cuando se ubican en un sitio 
cocatalítico hay varios iones unidos unos con otros en donde uno de ellos desempeña una función catalizadora y el resto de los iones mejoran la actividad catalítica del sitio. Por último, el Zn en su función estructural, participa estabilizando la estructura terciaria de la enzima de manera análoga al puente disulfuro. En todos los casos, la eliminación del Zn de su sitio de acción puede llevar a la pérdida de la actividad enzimática (McCall y col., 2000).

El Zn forma parte de aproximadamente 300 enzimas. Algunas de estas pertenecen al grupo de las metaloproteinasas (matrix metaloproteinases) como las colagenasas, gelatinasas y endometasas entre otras. Estas enzimas intervienen en la proliferación y motilidad celular, en el proceso de cicatrización de heridas, en la angiogénesis y en el control de eventos reproductivos claves como la ovulación, la implantación embrionaria, la embriogénesis, la involución uterina, la involución mamaria y prostática, y la proliferación endometrial (Hulboy y col., 1997; Amălinei y col., 2007). Las enzimas alcohol deshidrogenasa, fosfatasa alcalina, anhidrasa carbónica y carboxipeptidasas A y B también forman parte de la extensa lista de enzimas zinc-dependientes (Underwood y Suttle, 1999).

El Zn forma estructuras denominadas "dedos de Zinc" que fueron definidos por Laity y colaboradores (2001) como cualquier dominio proteico pequeño, funcional, plegado de forma independiente que requiere la coordinación de uno o más iones de Zn para estabilizar su estructura. Las proteínas con dedos de Zn forman parte de una gran cantidad de receptores de membrana, nucleoproteínas y más de 1000 factores de transcripción (Cousins, 1999; Beyersmann y Haase, 2001). Las funciones de estas estructuras son extraordinariamente diversas e incluyen el reconocimiento del ADN, el empaquetamiento del ARN, la activación de la transcripción, la regulación de la apoptosis, el ensamble y plegamiento de las proteínas y la unión de éstas a lípidos (Laity y col., 2001). Es principalmente por la participación del Zn en la expresión génica que este mineral posee vital importancia en la digestión, la glucólisis, la 
síntesis de ADN, la síntesis de ácido nucleíco, en la división celular y el metabolismo de las proteínas (Underwood y Suttle, 1999).

El Zn posee también un conocido desempeño como agente antioxidante. Su capacidad para retardar los procesos oxidativos es reconocida desde hace muchos años (Powell, 2000). Este mineral ejerce su efecto protector en forma mediata (también llamada crónica) o inmediata (aguda). La primera implica la exposición al Zn por un largo periodo de tiempo, resultando en la inducción de alguna otra sustancia, como la metalotioneína, que finalmente ejecuta la acción antioxidante. El efecto inmediato por otro lado, se realiza mediante dos mecanismos: a) reduciendo la formación de radicales hidroxilo por parte de los iones $\mathrm{Fe}^{++}$y $\mathrm{Cu}^{+}$(Reacción de Fenton) al competir por los sitios de unión de ambos metales y b) protegiendo de la oxidación a los grupos sulfidrilos de las proteínas. Para esto último existen tres mecanismos: (b1) la unión directa del Zn al sulfidrilo, (b2) el impedimento estérico como resultado de la unión de Zn con otro sitio de la proteína próximo al grupo sulfidrilo y (b3) produciendo un cambio conformacional como resultado de la unión del Zn con algún otro sitio de la proteína (Figura 23) (Powell, 2000; Chihuailaf y col., 2002). El Zn también forma parte de la Cu/Zn-SOD que es una de las principales enzimas del sistema antioxidante del organismo (Rosa y col., 2008; Batinić-Haberle y col., 2010; Buettner, 2011). Esta tiene por función catalizar la dismutación del radical libre superóxido a peróxido de hidrógeno, lo que no requiere de cosustratos (Chihuailaf y col., 2002).

El Zn cumple un rol central en el sistema inmunológico. Este microelemento es crucial para el normal desarrollo y función de las células mediadoras de la inmunidad inespecífica como los neutrófilos y células natural killers (Shankar y Prasad, 1998). La deficiencia de Zn también afecta el desarrollo de la inmunidad adquirida al reducir el número de linfocitos T y $\mathrm{B}, \mathrm{y}$ su función. La producción de citoquinas y anticuerpos (particularmente la inmunoglobulina G) también se ve comprometida cuando la presencia de $\mathrm{Zn}$ en el organismo se encuentra 
disminuida. El macrófago en un estado de deficiencia de Zn, puede presentar alteraciones en su capacidad lítica, en la producción de citoquinas y en la fagocitosis. Entre las diversas funciones que desarrolla el Zn en la inmunidad, se encuentra la expresión de genes y la mitosis de las células linfoides. Esto se debe a que la ADN polimerasa, la principal enzima que regula la replicación del ADN, es una enzima Zn-dependiente (Shankar y Prasad, 1998; Erickson y col., 2000).

Figura 23. Mecanismos de protección contra la oxidación de grupos sulfidrilos de las proteínas por Zinc (Powell, 2000).

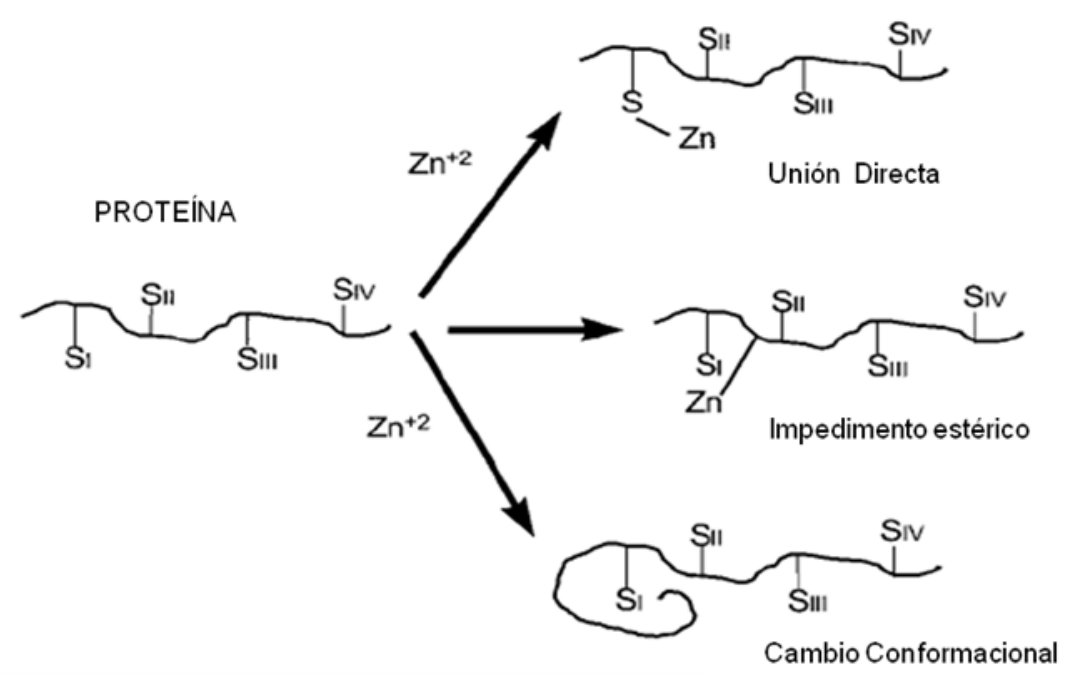

Además de lo anteriormente expuesto, existe nueva evidencia que señala al Zn iónico $\left(\mathrm{Zn}^{++}\right)$como posible factor de señalización celular (Beyersmann y Haase, 2001). Según estos 
autores, el Zn sería secretado y luego de la unión a un receptor específico podría regular una función orgánica al igual que lo hacen las hormonas locales.

\subsubsection{Manifestaciones bioquímicas de la deficiencia de zinc}

El desarrollo de la carencia Zn ocurre en tres etapas: depleción, deficiencia y disfunción. La depleción ocurre cuando el requerimiento neto de este mineral no es cubierto por la dieta y comienza a ser movilizado desde los diferentes tejidos. Esta etapa puede continuar durante un largo período sin consecuencias para la producción. Cuando el Zn movilizado comienza a agotarse empieza la etapa de deficiencia, caracterizada por una disminución de la concentración plasmática de Zn. Finalmente, sobreviene la etapa de disfunción, cuando las metaloproteínas específicas se ven afectadas en su funcionamiento. Los daños bioquímicos generados por las disfunciones proteicas y/o enzimáticas producen finalmente la última etapa de la carencia, con manifestaciones subclínicas y luego clínicas de la enfermedad (Underwood y Suttle, 1999; Rosa y col., 2008) (Figura 24). Las concentraciones plasmáticas de Zn fluctúan con la edad, el estrés, las infecciones, y la restricción alimenticia. En terneros recién nacidos la zinquemia es muy alta $(2,3 \mu \mathrm{g} / \mathrm{ml})$, disminuyendo notablemente cuando el animal alcanza la semana 12 de vida (1,2 $\mu \mathrm{g} / \mathrm{ml}$ ) (Kincaid y col., 1976). Kincaid (1999) definió el estatus de Zn en el bovino utilizando valores de Zn en plasma. Éste autor propone dividir el estatus mineral en tres grupos: deficiente $(0,2$ a $0,4 \mu \mathrm{g} / \mathrm{ml} \mathrm{Zn})$; deficiente marginal $(0,5$ a $0,8 \mu \mathrm{g} / \mathrm{ml} \mathrm{Zn})$ y adecuado $(0,8$ a $1,9 \mu \mathrm{g} / \mathrm{ml} \mathrm{Zn})$.

Las consecuencias clínicas de la enfermedad dependen de la severidad de la deficiencia, pero la sintomatología clásica incluye: anorexia, crecimiento retardado, pérdida de peso, alteración de la respuesta inmune, retraso de la maduración sexual, atrofia testicular e hiperqueratinización epidérmica (Grahn y col., 2001). La sintomatología poco específica da nota 
del fundamental papel que cumple el Zn en el metabolismo celular (Aggett y Comerford, 1995; Grahn y col., 2001).

Figura 24. Etapas de la deficiencia de Zn (Modificado de Rosa y col., 2008)

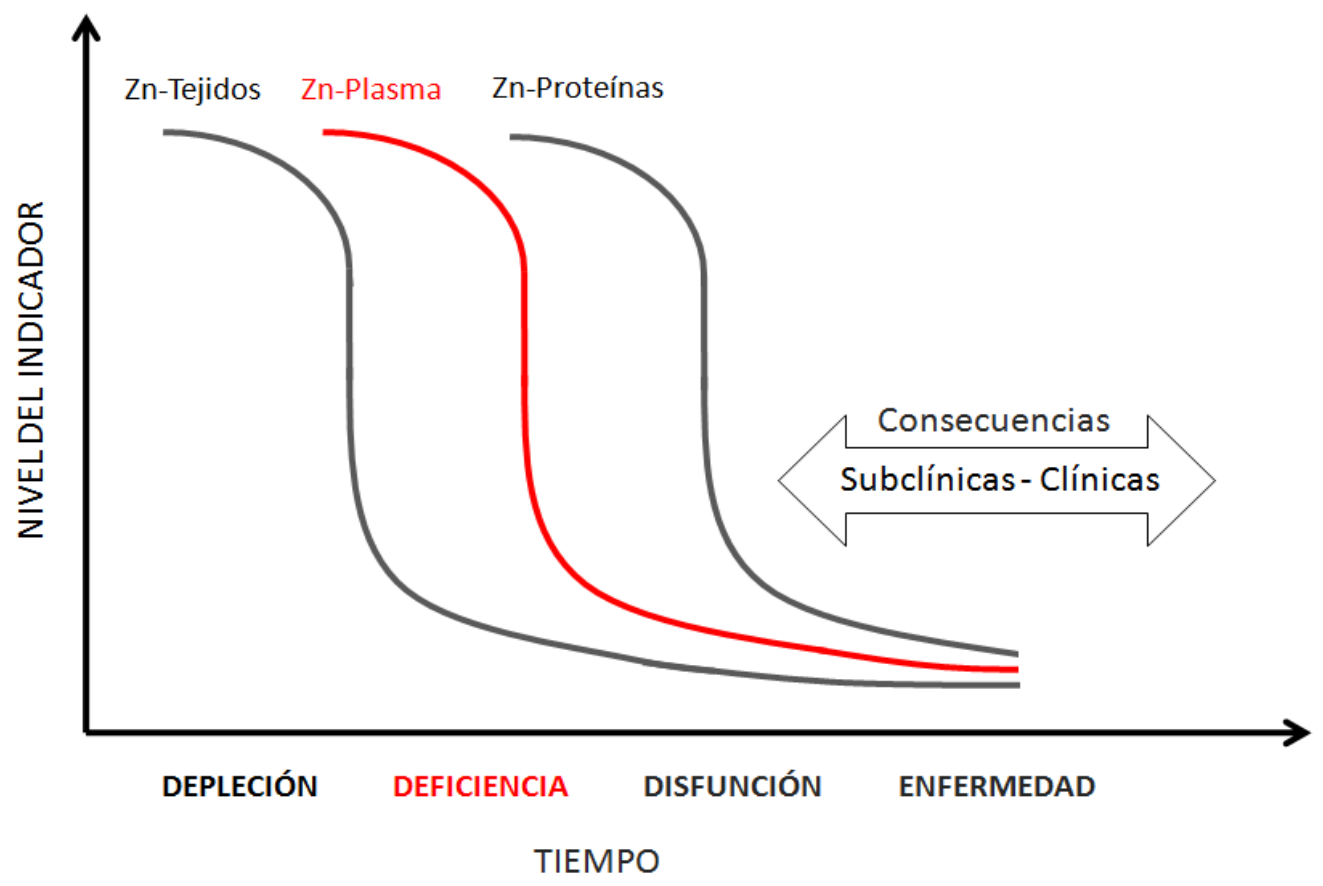

El Zinc se encuentra presente en soluciones fisiológicas como un catión divalente electrofílico $\left(\mathrm{Zn}^{++}\right)$que se une débilmente a ligandos de bajo peso molecular. In vitro, se une principalmente a la albúmina y cuando se encuentran presentes células, se asocia a los puentes sulfhidrilos de las proteínas de sus membranas plasmáticas (Eide, 2006). El Zn es un componente importante para el cultivo celular. Sin embargo, los medios clásicos por lo general no lo contienen en sus fórmulas. La inclusión de 5 a $10 \%$ de suero al medio, le proporciona el nivel mínimo de Zn necesario para el crecimiento y la supervivencia celular. 
Como se mencionó anteriormente, el Zn interviene en la función y estabilidad génica. Forma parte de múltiples factores de transcripción, incluyendo proteínas de unión al ADN, y más de 300 enzimas, como la Cu/Zn-SOD y proteínas implicadas en la reparación del ADN (Falchuk, 1998; Prasad, 2003; Cathomen y Joung, 2008). Por lo tanto, el Zn juega un papel preponderante en la acción antioxidante y evita el daño en el ADN. Es importante destacar que la deficiencia de Zn resulta en un aumento en la sensibilidad al estrés oxidativo (Taylor y col., 1988). Se ha descripto además, que la disponibilidad de $\mathrm{Zn}$ puede influir en las funciones celulares y en el desarrollo embrionario (Falchuk, 1998; Hostetler y col., 2003). El Zn se encuentra presente en cigotos y embriones formando parte de las metaloproteínas involucradas en el desarrollo embrionario y la organogénesis (Kambe y col., 2008). La deficiencia de este mineral durante el desarrollo en los vertebrados produce alteraciones en la morfogénesis de los órganos dorsales, incluyendo el cerebro, los ojos y la médula espinal (Falchuk y Montorzi, 2001). Su carencia en los machos produce hipogonadismo, oligospermia y la alteración de la esteroidogénesis (Kumar y col., 2006; Yamaguchi y col., 2009), mientras que en las mujeres afecta el ciclo estral y aumenta el riesgo de aborto espontáneo (Graham y col., 1994).

Diversos estudios de manejo nutricional en los animales domésticos apuntan a dilucidar problemas de impacto reproductivo (Novak y col., 2003). La nutrición puede influir entre otras cosas la sobrevida embrionaria y el desarrollo folicular y como consecuencia la calidad del ovocito (Almeida y col., 2001; Mao y col., 2002). En consecuencia, es posible que el desarrollo embrionario preimplantacional en animales domésticos como los bovinos requieran de la incorporación de varios micronutrientes para una buena función reproductiva. Sin embargo, los estudios dedicados a evaluar la influencia de micronutrientes como el Zn en ovocitos y embriones tempranos resultan en algunos casos limitados. 
Por lo tanto, el objetivo general del presente trabajo fue estudiar el efecto del Zn, en distintas concentraciones sobre la adquisición de la capacidad de desarrollo de los ovocitos durante el período de maduración y su impacto en el desarrollo embrionario temprano posterior. Para ello, se utilizó como modelo experimental la técnica de producción in vitro de embriones bovinos.

Los objetivos específicos para llevar a cabo el presente trabajo de tesis pueden ser resumidos en los siguientes puntos:

Capítulo 1: Determinación de la concentración de Zn en plasma, licor folicular y en el medio de maduración completo.

Capítulo 2: Efecto de distintas concentraciones de Zn sobre la maduración in vitro de los ovocitos bovinos.

Capítulo 3: Efecto de distintas concentraciones de Zn sobre la capacidad de desarrollo de los ovocitos hasta el estadio preimplantacional de blastocisto.

Capítulo 4: Rol de las células del cúmulus como puente metabólico entre el medio externo y el ovocito, con diferentes niveles en el aporte de Zn durante la MIV. 
Material y Métodos 


\subsection{Técnica de producción de embriones bovinos in vitro}

La producción in vitro de embriones involucra tres etapas fundamentales: 1) Maduración in vitro, 2) Fecundación in vitro y 3) cultivo in vitro de embriones (CIV). Para la MIV de ovocitos bovinos se utilizó el medio de cultivo TCM-199 suplementado con hormonas, LH y FSH y suero fetal bovino (SFB). Para la FIV se empleó el medio TALP (Parrish y col. 1984) y para el CIV el medio SOFm (Synthetic Oviduct Fluid modificado) (Tervit y col. 1972; Gardner y col., 1994). El éxito de la FIV depende de la calidad de las gametas, de la composición de los medios empleados para capacitar el semen, de las condiciones del laboratorio y de la habilidad del operador. En el caso de los bovinos, Parrish y colaboradores (1984) demostraron que los espermatozoides de toro podían capacitarse in vitro en un medio de fecundación-capacitación con heparina. Estudios posteriores, establecieron que la concentración de heparina utilizada afecta la tasa de desarrollo embrionario posterior hasta el estadio de blastocisto (Parrish y col., 1985a, 1985b; 1988), que existe una concentración adecuada para la capacitación del semen de cada toro (Lancaster y col., 1990; Chung y col., 1991) y que el tiempo de incubación de los espermatozoides en el medio de capacitación es un factor determinante para lograr una FIV exitosa (Fukui y col., 1990). Por lo tanto, antes de iniciar los ensayos experimentales de la presente tesis doctoral se llevó a cabo la puesta a punto de la técnica de producción in vitro de embriones bovinos que se utilizó como modelo experimental durante el desarrollo del presente trabajo de tesis.

\subsection{Reactivos}

Todos los reactivos fueron provistos por Sigma Chemical Company (St. Louis, EE.UU.), a menos que se indique lo contrario. Todos los medios y soluciones (Anexos) se prepararon con 
agua Tipo I (Sigma) y fueron almacenados a $4{ }^{\circ} \mathrm{C}$ en oscuridad. La técnica de Producción in vitro de embriones se utilizó como modelo experimental para el desarrollo del presente trabajo de tesis. Las técnicas específicas se describen en el capítulo correspondiente.

\subsection{Maduración in vitro (MIV)}

Los ovarios de frigorífico extraídos de hembras jóvenes, se colocaron en solución fisiológica a $37-39^{\circ} \mathrm{C}$ y se mantuvieron en termos hasta llegar al laboratorio. Luego se lavaron tres veces en solución fisiológica con antibióticos. De cada ovario se aspiraron los folículos de 2 - 8 mm usando una aguja de 18 G conectada a un tubo estéril y a una línea de vacío (50 mm $\mathrm{Hg}$ ). Los complejos ovocito-cúmulus (COC) se colectaron a menor aumento $(20$ X) con un microscopio estereoscópico y platina térmica a $39{ }^{\circ} \mathrm{C}$ y, se colocaron en medio Hepes-199 + 10 \% SFB (Medio de mantenimiento) hasta el momento de la selección por calidad. Para la MIV, se eligieron los COC cuyos ovocitos presentaron el citoplasma homogéneo y las células del cúmulus compactas. Los COC se lavaron dos veces en medio de MIV, se tomaron grupos de 10 COC en $10 \mu \mathrm{l}$ de medio, se sembraron en gotas de $40 \mu \mathrm{l}$ de medio bajo aceite mineral y se incubaron a $39^{\circ} \mathrm{C}$ en atmósfera gaseada con $5 \% \mathrm{CO}_{2}$ en aire y humedad a saturación.

\section{Preparación de cajas para MIV:}

Las cajas de Petri para MIV se prepararon previamente a la recolección de los COC con gotas de $40 \mu \mathrm{l}$ de medio de maduración, cubiertas con aceite mineral. Posteriormente, las cajas de MIV se incubaron durante 2 hs a $39{ }^{\circ} \mathrm{C}$ en atmósfera gaseada con $5 \%$ de $\mathrm{CO}_{2}$ en aire y humedad a saturación para equilibrar el pH $(7,2$ - 7,4) del medio. El volumen final de las gotas de MIV fue de $50 \mu \mathrm{l}: 40 \mu \mathrm{l}$ de medio de MIV $+10 \mu \mathrm{l}$ con los COC. 


\subsection{Fecundación in vitro (FIV)}

a) Preparación de las cajas de FIV

Luego de preparar el medio de FIV (Anexos), se armaron las placas de Petri con gotas de $30 \mu \mathrm{l}$ de medio y se cubrieron con aceite mineral. Las cajas fueron incubadas para equilibrar el $\mathrm{pH}$ del medio $(7,2-7,4)$ a $39{ }^{\circ} \mathrm{C}$ en atmósfera gaseada con $5 \% \mathrm{CO}_{2}$ en aire y humedad a saturación durante un tiempo mínimo de 2 hs.

b) Preparación de los ovocitos para la FIV.

Después de 24 hs de MIV se lavaron los COC rápidamente en Hepes-TALP sin quitarles las células del cúmulus. Luego se lavaron 2 veces en medio FIV, se tomaron entre 5 a 10 COC en un volumen de $10 \mu \mathrm{l}$ de medio y se sembraron en cada gota de FIV preparada previamente. Los COC se mantuvieron en estufa a $39{ }^{\circ} \mathrm{C}$ hasta el momento de la inseminación.

\section{c) Procesamiento del semen}

Con el objetivo de separar los espermatozoides vivos se utilizó un gradiente de Percoll. En un tubo cónico de $15 \mathrm{ml}$ se colocaron $2 \mathrm{ml}$ de Percoll 90 \% y se agregaron cuidadosamente sobre él $2 \mathrm{ml}$ de Percoll $45 \%$. Luego, se descongelaron 2 pajuelas de semen, se evaluó la calidad del mismo y se sembró sobre la superficie del gradiente de Percoll. El gradiente se centrifugó a 700 g durante 15 - 30 minutos y se retiró cuidadosamente el pellet (espermatozoides vivos) con una pipeta Pasteur para transferirlo a otro tubo. Se agregó $250 \mu \mathrm{l}$ de Hepes-TALP, se homogeneizó agitando suavemente y se volvió a centrifugar a $200 \mathrm{~g}$ durante 5 min. Luego de descartar el sobrenadante el pellet se resuspendió en $200 \mu$ l de medio de FIV y se mantuvo en la incubadora. Se tomó una muestra para determinar la concentración 
de espermatozoides utilizando una cámara de Neubauer y microscopio óptico. Finalmente se ajusto el volumen con medio de FIV para obtener una suspensión de 10 millones de espermatozoides/ml.

d) Inseminación

Se agregó rápidamente $10 \mu \mathrm{l}$ de la suspensión concentrada de espermatozoides (10 millones/ml) a las gotas de FIV que ya contenían los ovocitos. Se incubó durante 24 hs a $39{ }^{\circ} \mathrm{C}$ en atmósfera gaseada con $5 \% \mathrm{CO}_{2}$ en aire con humedad a saturación. La concentración final de espermatozoides en la gota de FIV fue de 2 millones $/ \mathrm{ml}$.

\subsection{Cultivo de embriones in vitro (CIV)}

Se prepararon gotas de $30 \mu \mathrm{l}$ con medio SOFm (Anexos) en cajas de Petri bajo aceite mineral. Las cajas de CIV se prepararon 2 horas antes de la siembra y se incubaron a $39{ }^{\circ} \mathrm{C}$ en atmósfera gaseada con una mezcla de $7 \% \mathrm{O}_{2}, 5 \% \mathrm{CO}_{2}, 88 \% \mathrm{~N}_{2}$ y humedad a saturación. Luego de 24 horas de FIV los presuntos cigotos se lavaron 2 veces en Hepes-SOF y 2 veces en SOFm. Grupos de 5 - 10 presuntos cigotos en $10 \mu$ de SOFm fueron sembrados en las gotas de $30 \mu \mathrm{l}$ previamente equilibradas, alcanzando un volumen final de $40 \mu \mathrm{l}$ de medio en las gotas de CIV. Los embriones se cultivaron en medio SOFm sin glucosa durante las primeras 24 horas de cultivo (D1) y SOFm con 1,5 mM de glucosa desde el día 2 (D2) hasta el día 8 (D8). El medio de cultivo se renovó cada 48 hs.

Al finalizar los 8 días de cultivo se evaluó la calidad morfológica de los embriones utilizando un microscopio invertido de epifluorescencia (Nikon, Diaphot). Los embriones se

colorearon con Hoechst 33342 que se une al ADN y permite determinar el número de células de 
los blastocistos al final del cultivo. Para la evaluación con Hoechst 33342 se utilizó un filtro UV2A.

\subsection{Coloración fluorescente para núcleos (HOESCHT 33342)}

Se preparó una solución de trabajo diluyendo 10 mg de Hoescht 33342 en 20 ml de etanol proanálisis $(500 \mu \mathrm{g} / \mathrm{ml})$. L os ovocitos o embriones se incubaron 2 minutos a temperatura ambiente en Hoechst 33342 y se montaron entre porta y cubreobjeto bajo lupa y se evaluaron con microscopio de epifluorescencia (Filtro UVA). 
Capitulo 1 


\section{Determinación de la concentración de $\mathrm{Zn}$ en plasma, licor}

\section{folicular y en el medio de maduración completo}

\subsection{Introducción}

Dentro del folículo ovárico el ovocito en desarrollo se encuentra embebido por el licor folicular (LF) que nutre al ovocito y a las células del cúmulus que lo rodean. El folículo es un compartimento avascular separado del estroma ovárico por la pared folicular quien forma la "barrera hemato-folicular" (Bagavandoss y col., 1983). Si bien, el LF es un trasudado del suero, también se encuentra parcialmente constituido por sustancias producidas localmente que están relacionadas a la actividad metabólica de las células foliculares (Gerard y col., 2002). Esta actividad metabólica, junto a la propiedad "barrera" de la pared folicular, cambian significativamente durante la fase de crecimiento del folículo, por lo que la composición del LF varía con los diferentes tamaños foliculares (Arshad y col., 2005). A pesar de la importancia que poseen los metales como el Zn sobre la reproducción, sus concentraciones en el LF no han sido hasta el momento bien caracterizadas (Silberstein y col., 2009). El conocimiento que hoy se tiene acerca del papel que cumplen los micronutrientes sobre los ovocitos y el desarrollo embrionario temprano, se basa principalmente en trabajos in vivo donde se han alterado las dietas maternas o se han suplementado a las madres de forma parenteral (Ashworth y Antipatis, 2001). La maduración del ovocito es una etapa crítica y compleja donde se desarrollan múltiples 
fenómenos que conducen a su maduración nuclear y citoplasmática (Sorensen y Wassarman, 1976; Downs, 1993; Edwards, 2000; Fan y Sun, 2004; van den Hurk y Zhao, 2005; Hashimoto, 2009). Se sabe que la deficiencia de $\mathrm{Zn}$ puede alterar algunos de estos eventos por lo que el aporte adecuado de este mineral debería ser garantizado durante este proceso (Sun y col., 2007; Kambe y col., 2008; Kim y col., 2011; Tian y Diaz, 2012).

Un estudio realizado en búfalos, por Arshad y colaboradores (2005) determinó que la concentración de Zn folicular y plasmático no presenta diferencias cuando se evalúa la concentración en folículos mayores y menores a $10 \mathrm{~mm}$. En condiciones in vitro, el medio de MIV representa el medio ambiente del ovocito y de su composición depende en gran medida, su capacidad de desarrollo posterior (Abeydeera, 2002; Martinez Madrid, 2002). Muy poco se conoce acerca de cuál es la concentración apropiada de Zn en este medio, pero probablemente se corresponda a la encontrada en el licor folicular de animales adultos saludables.

Por lo expuesto, el objetivo fue determinar las concentraciones de Zn en plasma, LF y en el medio de MIV completo para establecer las concentraciones de trabajo.

\subsection{Material y métodos}

\subsubsection{Determinación de Zinc en plasma, licor folicular y medio de MIV}

Se colectaron 40 muestras de sangre $(10 \mathrm{ml})$ de la vena yugular de vaquillonas al momento de la faena en tubos con EDTA. Las muestras se centrifugaron a 3000 rpm por 10 minutos, se separó el plasma y se guardó a $4{ }^{\circ} \mathrm{C}$. Los ovarios de las mismas vaquillonas se colectaron e individualizaron para asociarlos a las muestras de sangre. Los ovarios se envolvieron en film y se transportaron al laboratorio en un recipiente térmico dentro de las 2 horas de obtenidos. El diámetro de los folículos ováricos se midió con un calibre y se 
clasificaron en dos grupos: a) Folículos pequeños (<10 mm) y b) Folículos grandes (> $10 \mathrm{~mm})$. El LF de cada grupo se obtuvo por aspiración con jeringas de insulina estériles. Además, se tomaron muestras $(n=6)$ de medio de MIV suplementado con $10 \%$ de SFB. Las muestras de LF y medio de MIV se centrifugaron y el sobrenadante se trató con $10 \%$ (p/v) de ácido tricloroacético. La concentración de Zn se midió con un espectrofotómetro de absorción atómica de flama (GBC 902).

\subsubsection{Análisis estadístico}

Los valores de concentración de Zn en plasma, LF y medio de MIV se analizaron utilizando ANOVA de una vía y el test de Student-Newman-Keuls a posteriori (CSS: Statistica, module C-Stasoft, Tulsa, OK, USA).

\subsection{Resultados}

\subsubsection{Determinación de Zinc en plasma, licor folicular y medio de MIV}

La concentración de $\mathrm{Zn}$ fue de 1,32 $\mu \mathrm{g} / \mathrm{ml} \pm 0,22$ en plasma; $1,49 \mu \mathrm{g} / \mathrm{ml} \pm$ 0,37 en LF de folículos grandes; $1,55 \mu \mathrm{g} / \mathrm{ml} \pm 0,33$ en $\mathrm{LF}$ de folículos pequeños y $0,3 \mu \mathrm{g} / \mathrm{ml} \pm 0,02$ en el medio de MIV. No se encontraron diferencias significativas entre las concentraciones de Zn en plasma y LF. Es necesario aclarar que el medio de maduración sin el suplemento de SFB no presentó concentraciones detectables de $\mathrm{Zn}$.

\subsection{Conclusiones}

La concentración de Zn fue similar en plasma y LF de folículos mayores y menores a 10 $\mathrm{mm}$ al igual que lo publicado 
en búfalo por Arshad y colaboradores (2005). En base a nuestros resultados y a los valores de Zn plasmático definidos por Kincaid (1999) en el bovino (pág. 72), se establecieron cuatro condiciones experimentales para el presente trabajo de tesis: un tratamiento Control que consistió en medio de maduración sin el agregado de Zn (concentración final del medio: 0,3

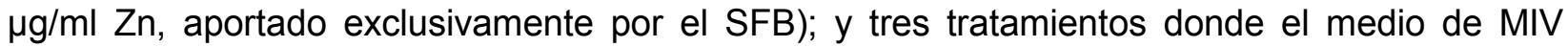
alcanzo las siguientes concentraciones finales de Zn: Zn1: 0,7 $\mu \mathrm{g} / \mathrm{ml}$; Zn2: 1,1 $\mu \mathrm{g} / \mathrm{ml}$ y Zn3: 1,5 $\mu \mathrm{g} / \mathrm{ml}$. El grupo Control y Zn1 corresponden al estatus de "deficiencia" y "deficiencia marginal" respectivamente, mientras que $\mathrm{Zn} 2$ y Zn3 corresponden al estatus "adecuado" propuesto por Kincaid (1999). 
Capitulo 2 


\section{Efecto de distintas concentraciones de Zn sobre la maduración}

\section{in vitro de los ovocitos bovinos}

\subsection{Introducción}

El complejo ovocito-cúmulus presente en el folículo antral de mamíferos, constituye una unidad estructural y funcional (Camaioni y col., 1993). Como consecuencia del aumento de gonadotrofinas endógenas durante el período preovulatorio, el espacio entre las células del cúmulus aumenta debido a la producción de una matriz extracelular rica en ácido hialurónico (AH). Este proceso, llamado expansión o mucificación, facilita el desprendimiento del COC de la pared del folículo, su extrusión en la ovulación, y su captura por las fimbrias del oviducto. Además, las células del cúmulus y la matriz extracelular del COC expandido, mejoran la penetración del espermatozoide y la fecundación. La expansión óptima de la masa del cúmulus es, por lo tanto, fundamental para la correcta ovulación y posterior fecundación del ovocito (Camaioni y col., 1993; Borg y Holland, 2008; Nagyova y col., 2012). En estudios in vitro, se ha observado que el grado de expansión del COC está directamente relacionado con la cantidad de AH sintetizado en la matriz extracelular (Chen y col., 1990). Recientemente, se ha demostrado que el Zn participa como cofactor de los factores de transcripción pSmad 2 y pSmad 3 que están relacionados con la síntesis y organización del $\mathrm{AH}$ dentro de la matriz extracelular (Tian y Diaz, 2012). 
El glutatión es el principal compuesto sulfatado no proteico presente en las células de mamífero. Este tiol cumple numerosas funciones biológicas, entre las que se encuentran el mantenimiento del estado redox intracelular, el transporte de aminoácidos y la síntesis de ADN, entre otros (Lafleur y col, 1994; Sies, 1999; Luberda, 2005). El GSH se encuentra ampliamente distribuido en los organismos animales, no sólo en las células somáticas, sino también en las gametas (Luberda, 2005). La síntesis de GSH es fundamental durante la maduración de los ovocitos y su función se relaciona principalmente con su propiedad antioxidante. Además, mantiene la morfología del uso mitótico y participa en la formación del pronúcleo masculino luego de la fertilización (Perreault y col., 1988; Yoshida y col., 1993; Sutovsky y Schatten, 1997; Zuelke y col., 1997; Gardiner y col., 1998; Ayalasomayajula y Kompella, 2002). Diversos estudios han demostrado que las concentraciones de GSH intracelular de los ovocitos en la etapa final de la MIV reflejan el grado de su maduración citoplasmática (de Matos y col., 1997; Furnus y col., 1998; de Matos y Furnus, 2000). El GSH es capaz de liberar el Zn de la metalotioneina en una reacción redox que involucra a su forma oxidada (GSSG) (Chen y Maret, 2001). El GSH actúa como un ligando biológico en la formación de complejos binarios y terciarios con el Zn; la reducción intracelular de este mineral causa una reducción en la concentración intracelular de GSH (Kojima-Yuasa y col., 2003; Krezel y col., 2003; Cortese y col., 2008).

La apoptosis, también conocida como muerte celular programada, es un proceso altamente regulado y crucial en todos los organismos multicelulares (Rana y col., 2008). Las células que mueren por apoptosis sufren una serie de cambios morfológicos y bioquímicos característicos, como la fragmentación del ADN, cambios en la simetría de la membrana, aumento en los niveles de proteínas relacionadas con la muerte celular y la activación de enzimas proteolíticas como las caspasas (Wyllie y col., 1980; Phelps y col., 2000; Rana y col., 
2008). La apoptosis representa el fenómeno final de una compleja ruta de señalización que culmina con la activación de las caspasas y la consecuente generación de alteraciones celulares que llevan a la muerte de la célula (Campbell y col., 1993; Clarke y col., 1994; Belka y col., 2000; Bonner y col., 2000; Brown y Baltimore, 2003). La apoptosis ocurre cuando el daño celular, incluyendo el daño en el material genético, ha sobrepasado la capacidad de la célula para repararse (Rana y col., 2008). Estudios previos demostraron que la atresia de los folículos subordinados en cada ciclo del recambio folicular, en animales de granja, se inicia y se debe principalmente a la apoptosis de las células de la granulosa (Manabe y col., 1996; Yang y Rajamahendran, 2000). En el caso de los bovinos, la información sobre el proceso de apoptosis es limitada a estudios realizados en células de la granulosa de los folículos ováricos y en menor medida en células del cúmulus durante la MIV de ovocitos (Jolly y col., 1994; Quirk y col., 2000; Yang y Rajamahendran, 2000; Luciano y col., 2000; Ikeda y col., 2003).

Estudios realizados in vitro en células somáticas de ratón, rata y mono han demostrado un claro aumento en el daño del ADN en presencia de bajos niveles de Zn (Olin y col., 1993; Oteiza y col., 1995, 2000). Se ha observado también, que los animales deficientes de Zn poseen una gran susceptibilidad al estrés oxidativo y en consecuencia presentan daño celular en la molécula de ADN (Taylor y Bray, 1991; Canali y col., 2000; Sakaguchi y col., 2002; Yousef y col., 2002; Ho y Ames, 2002; Ho y col., 2003; Bruno y col., 2007). El daño en el ADN puede ser el producto final del fenómeno de apoptosis o uno de los responsables de su desarrollo (Wang, 2001; Norbury y Zhivotovsky, 2004; Rana y col., 2008; Song y col., 2009). El Zn participa activamente en mantener la integridad del ADN, no solo por su propiedad antioxidante, sino que además, el Zn forma parte de muchas de las proteínas involucradas en su reparación (Ho, 2004). Por lo tanto, el daño en el material genético de células deficientes de Zn es 
consecuencia de situaciones de estrés oxidativo y al deterioro de las funciones de reparación (Canali y col., 2000; Ho y Ames, 2002; Bruno y col., 2007).

La enzima superóxido dismutasa (SOD) protege a las células del daño causado por los radicales libres $(R L)$ del oxígeno al catalizar la dismutación del $R L$ superóxido $\left(\mathrm{O}_{2}{ }^{-}\right)$a peróxido de hidrógeno $\left(\mathrm{H}_{2} \mathrm{O}_{2}\right)$ (Chihuailaf y col., 2002). Este último compuesto es menos reactivo y es convertido posteriormente a oxígeno libre y agua (de Rosa y col., 1980). Se han identificado tres isoformas de SOD en mamíferos: dos isoformas unidas a cobre y zinc (Cu/Zn-SOD), una de ellas localizada en el citosol (Cu/Zn-SOD 1) y la otra en el medio extracelular (Cu/Zn-SOD 3), y una isoforma unida a manganeso (Mn-SOD) que se encuentra presente en la matriz mitocondrial (Miao y Clair, 2009). La Cu/Zn-SOD1 se localiza principalmente en el citosol pero también se encuentra en el núcleo, lisosomas, peroxisomas y entre las membranas de la mitocondria (Weisiger y Fridovich, 1973; Chang y col., 1988; Field y col., 2003). Estudios en ratones Knock-out para Cu/Zn-SOD indican que la eliminación de esta enzima se encuentra asociada a un mayor daño hepático (Polavarapu y col., 1998; Kessova y col., 2003), formación de hepatocarcinomas (Elchuri y col., 2005), infertilidad en la hembra (Matzuk y col., 1998), pérdida de neuronas motoras luego de un daño axónico (Reaume y col., 1996) y a un acortamiento del período de vida (Elchuri y col., 2005). La unión del metal a la proteína SOD es esencial para su correcto funcionamiento biológico. La pérdida de Zn desorganiza la estructura terciaria del sitio activo de la enzima y deja al Cu más accesible a las moléculas celulares, lo que genera reacciones oxidativas adversas (Sahawneh y col., 2010). Esto se ha confirmado mediante la observación de muchas SOD mutantes. Cuando la mutación no afecta la unión del Cu o Zn a la proteína, la enzima mantiene completamente su actividad (Borchelt y col., 1994; Marklund y col., 1997). Sin embargo, en humanos cuando la SOD pierde esta afinidad (como 
ocurre en la enfermedad de Lou Gehrig donde la enzima posee de 5 a 50 veces menos afinidad al Zn que su contraparte normal) se producen alteraciones en su funcionamiento.

En consecuencia, se diseñaron una serie de experimentos para estudiar el efecto de la adición de diferentes concentraciones de Zn al medio de MIV sobre: 1) la expansión del cúmulus de ovocitos bovinos, 2) los niveles intracelulares de GSH en ovocitos y células del cúmulus, 3) la tasa de apoptosis de las células del cúmulus, 4) la integridad del ADN de las células del cúmulus y 5) la actividad SOD del complejo ovocito-cúmulus.

\subsection{Material y métodos}

\subsubsection{Complejos Ovocito-Cúmulus (COC)}

Los ovarios bovinos fueron obtenidos a partir de hembras de frigorífico, independientemente del estado del ciclo estral y transportados al laboratorio en solución fisiológica estéril con antibióticos, a $37^{\circ} \mathrm{C}$, dentro de las 3 horas de realizada la extracción. Los COC fueron aspirados de folículos de 2 a $8 \mathrm{~mm}$ de diámetro, utilizando una aguja $18 \mathrm{G}$ conectada a un tubo estéril y a una línea de vacio $(50 \mathrm{~mm} \mathrm{Hg})$. Solamente fueron seleccionados para la MIV, aquellos COC que presentaron el cúmulus intacto y el citoplasma homogéneo. Para la selección, se utilizó un estereomicroscopio con bajo aumento (20 - 30 X). Las repeticiones de cada experimento $(n=4 / 5)$ se realizaron en días diferentes y en cada día se obtuvieron 200 COC, utilizando 50 COC por tratamiento.

\subsubsection{Maduración in vitro (MIV)}

Los COC fueron lavados 2 veces en medio TCM-199 con 15 mM de HEPES suplementado con $10 \%(\mathrm{v} / \mathrm{v})$ de suero fetal bovino. Luego se lavaron 2 veces en medio de MIV 
(TCM-199 suplementado con SFB, FSH y LH). Para la maduración se tomaron grupos de 10 COC y se transfirieron a microgotas de $50 \mu \mathrm{l}$ de medio de MIV bajo aceite mineral (Squibb, Princeton, $\mathrm{NJ}$, USA) previamente equilibradas en atmósfera gaseada al $5 \%$ de $\mathrm{CO}_{2}$, a $39{ }^{\circ} \mathrm{C}$ y humedad a saturación por 24 hs. La concentración de Zn en el medio de MIV fue de 0,3 $\mu \mathrm{g} / \mathrm{ml}$ (Control), concentración aportada exclusivamente por el SFB (3.3.1). El Zn fue agregado al medio de MIV de modo de alcanzar las siguientes concentraciones: Zn1) 0,7 $\mu \mathrm{g} / \mathrm{ml}$; Zn2) 1,1 $\mu \mathrm{g} / \mathrm{ml}$ y $\mathrm{Zn} 3) 1,5 \mu \mathrm{g} / \mathrm{ml}$.

\subsubsection{Evaluación de la expansión del complejo ovocito-cúmulus}

El área de expansión del cúmulus (AEC) de cada COC se midió antes (T0) y después de la MIV (T24) mediante un sistema de captura y digitalización de imágenes (SONY-CCD) acoplado a un software de análisis de imágenes microscópicas (Image ProPlus ${ }^{\circledR}$ 3.1) que permite realizar mediciones de áreas irregulares (Figura 25). El sistema de unidades fue transformado a $\mu \mathrm{m}^{2}$ por calibración con una cámara Makler. Además, se determinó el número de células del cúmulus por COC para cada grupo experimental. Para ello, los COC ya sean compactos (T0) o expandidos (T24), fueron disgregados mecánicamente por pipeteo bajo microscopio estereoscópico en medio HEPES-TCM-199. Las suspensiones celulares fueron transferidas a tubos Eppendorf y se determinó el número promedio de células por COC con una cámara hemocitométrica. 
Figura 25. Medición del área de expansión del cúmulus en imagen microscópica de COC (40 X) en TO (izquierda) y luego de 24 horas de MIV (derecha).
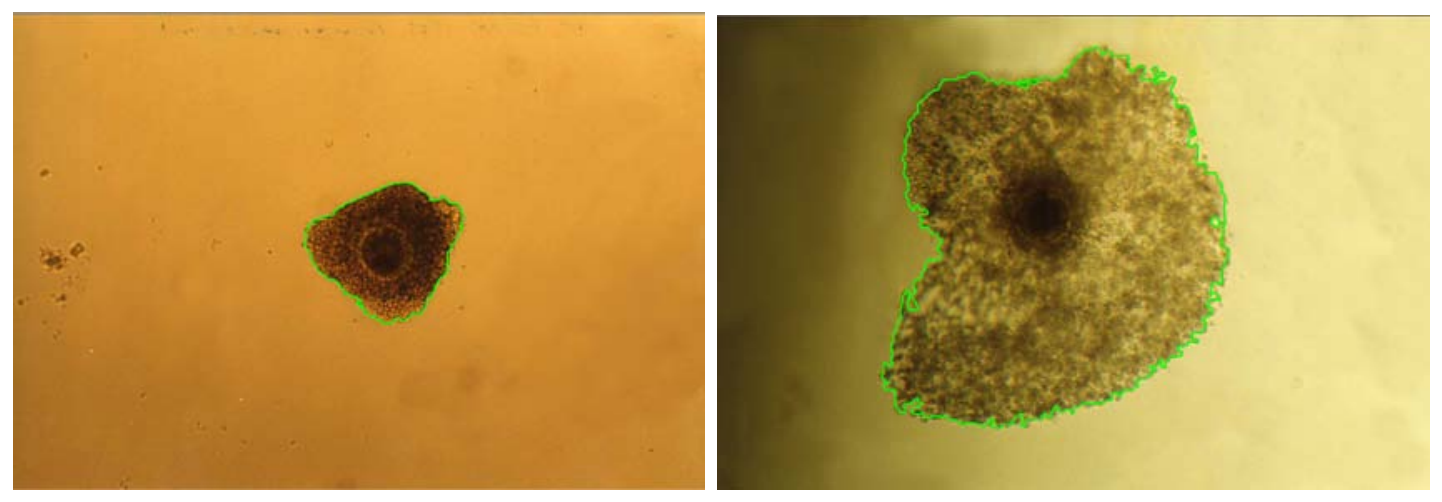

\subsubsection{Ensayo de GSH-GSSG}

Luego de la MIV los ovocitos se separaron de las células del cúmulus por pipeteo en Hepes-TCM-199 y luego se lavaron 3 veces en PBS libre de $\mathrm{Ca}^{++} / \mathrm{Mg}^{++}$. La lisis de los ovocitos se realizó por congelamiento/descongelamiento y aspiraciones repetidas con micropipeta. Las células del cúmulus de $\geq 50$ COC se transfirieron a tubos Eppendorf y se lavaron 2 veces en PBS por centrifugación a 14.000 g por 10 segundos. El pellet se resuspendió en $500 \mu$ l de PBS y la concentración de células se contó en una cámara hemocitométrica. La lisis de las células del cúmulus se logró también por congelamiento/descongelamiento y aspiraciones repetidas con aguja $26 \mathrm{G}$. Las muestras se diluyeron con $1,2 \mathrm{ml}$ de buffer fosfato $0,2 \mathrm{M}$ conteniendo 10 mM de EDTA. Luego se agregó $100 \mu$ l de DTNB 10 mM, 1 unidad de glutatión reductasa y $50 \mu$ l de NADPH 4,3 mM. El incremento de absorbancia se midió a $412 \mathrm{~nm}$ cada 30 segundos hasta completar 5 minutos con un espectrofotómetro de doble haz (Beckman Mod. 35, Irvine, CA, 
USA). La concentración total de GSH-GSSG (reducido-oxidado) en ovocitos y células del cúmulus se calculó a partir de la curva estándar de GSH.

\subsubsection{Ensayo de apoptosis (Anexina V)}

La Anexina $\mathrm{V}$ es una proteína de unión a fosfolípidos dependiente de $\mathrm{Ca}^{++}$con una gran afinidad por la fosfatidilserina (PS). La PS usualmente se ubica en la monocapa lipídica interior de la membrana plasmática. Cuando la célula sufre apoptosis, la PS se redistribuye quedando expuesta en la superficie de la célula (Glander y Schaller 1999; Paasch y col., 2004). La tasa de apoptosis temprana fue evaluada utilizando un kit de tinción de Anexina-V-Fluos (Roche, Cat $\mathrm{n}^{\circ}$ 11-858-777-001). La prueba involucra la tinción simultánea con Anexina-V-FLUOS (verde) y el colorante de ADN, ioduro de propídio (IP, rojo). Las células normales observadas al microscopio no presentan ninguna de las dos tinciones. Las células apoptóticas son visibles en color verde y pueden ser diferenciadas de las células necróticas por la tinción con IP (se tiñen de verde y naranja) (Figura 26). Las células del cúmulus $\left(1 \times 10^{6}\right.$ cél.) fueron lavadas dos veces en PBS por centrifugación a $200 \mathrm{~g}$ por 5 min. Luego el pellet fue resuspendido en $100 \mu$ l de solución de marcado (Anexina-V + fluoresceína +buffer de HEPES y IP) e incubado a $15-20{ }^{\circ} \mathrm{C}$ en oscuridad durante 10 a 15 min.

\subsubsection{Ensayo cometa (Integridad del ADN)}

Al finalizar la MIV, los ovocitos de cada tratamiento fueron separados de las CC por pipeteo repetido con pipeta de vidrio en medio HEPES-TCM-199. Las CC fueron lavadas tres veces en PBS libre de $\mathrm{Ca}^{++} / \mathrm{Mg}^{++}$con $1 \mathrm{mg} / \mathrm{ml}$ PVP (Polivinilpirrolidona) y posteriormente disgregadas por aspiraciones con pipeta Pasteur de punta fina. Las muestras se mezclaron con agarosa de bajo punto de fusión y se realizó la electroforesis en gel de células individuales, 
utilizando la versión alcalina descripta por Singh y colaboradores (1988) y modificada por Tice y Strauss (1995). Para ello, los portaobjetos fueron cubiertos con una capa de $180 \mu \mathrm{l}$ de agarosa normal al 0,5\% (Carlsbad, Carlsbad, CA, USA), las CC se mezclaron con $75 \mu \mathrm{l}$ de agarosa de bajo punto de fusión al 0,5\% (Carlsbad), se sembraron sobre los portaobjetos e inmediatamente se protegieron con cubreobjetos. Luego de la solidificación de la agarosa a $4{ }^{\circ} \mathrm{C}$ por 10 min., los cubreobjetos fueron removidos y los portaobjetos fueron sumergidos en solución de lisis durante toda la noche a $4{ }^{\circ} \mathrm{C}$. Al día siguiente, los portaobjetos fueron equilibrados en solución alcalina durante 20 min. y la electroforesis se realizó a $25 \mathrm{~V}$ y $300 \mathrm{~mA}(1,25 \mathrm{~V} / \mathrm{cm})$ por $30 \mathrm{~min}$. Luego de la corrida electroforética, los portaobjetos fueron neutralizados mediante tres lavajes de 5 min. cada uno con buffer TRIS $(\mathrm{pH} 7,5)$ y luego con agua destilada. Las muestras fueron teñidas con una solución 1/1000 de SYBR Green I (Molecular Probes, Eugene, OR, USA) (Olive y col., 1999). El conteo se realizó a 400 X con un microscopio de fluorescencia (Olympus BX40 equipado con un filtro de 515-560 nm) conectado a una cámara de video (Sony 3 CCD-IRIS) (Figura 27). Basado en la presencia o no de ADN migrado en el gel (ADN fragmentado: "cola del cometa"), las células fueron clasificadas como células "Con o Sin Daño" respectivamente. Posteriormente, de acuerdo a la cantidad del ADN migrado, es decir, de acuerdo a la longitud de la cola del cometa las células se clasificaron en cinco categorías o grados: Grado 0 (cola no visible), Grado 1 (cometas con cola delgada), Grado 2 (cometas con cola difusa), Grado 3 (cometas con colas bien definidas), y grado 4 (cometas con una clara disminución en el diámetro de la cabeza y con una cola bien definida) (Figura 27a). Las unidades de valor del daño del ADN fueron establecidas arbitrariamente de acuerdo a lo propuesto por Collins (Collin, 2004). Se obtuvo el Índice de Daño del ADN (IDD) de la siguiente manera: se evaluaron 100 cometas y a cada uno se le asignó un valor de 0 a 4 (según la clasificación de Grados), por lo tanto, el valor total para el portaobjetos fue de 0 a 400 "unidades arbitrarias" (Collins, 2004). Se determinó además, el valor de Olive Tail Moment (OTM). El OTM es un índice que corresponde 
al resultado del producto entre el porcentaje de ADN que constituye la cola y la distancia existente entre los centros de la cabeza y la cola del cometa (Olive y col., 1993; Poul y col., 2004). Para ello, las imágenes fueron procesadas utilizando el software Casp ${ }^{\circledR}$ (Figura 27b).

Figura 26. Imagen tomada con microscopio de fluorescencia a 400 aumentos donde pueden observarse las células positivas para Anexina $\vee$ (Izquierda) y una célula solo con contraste de fase (Derecha).
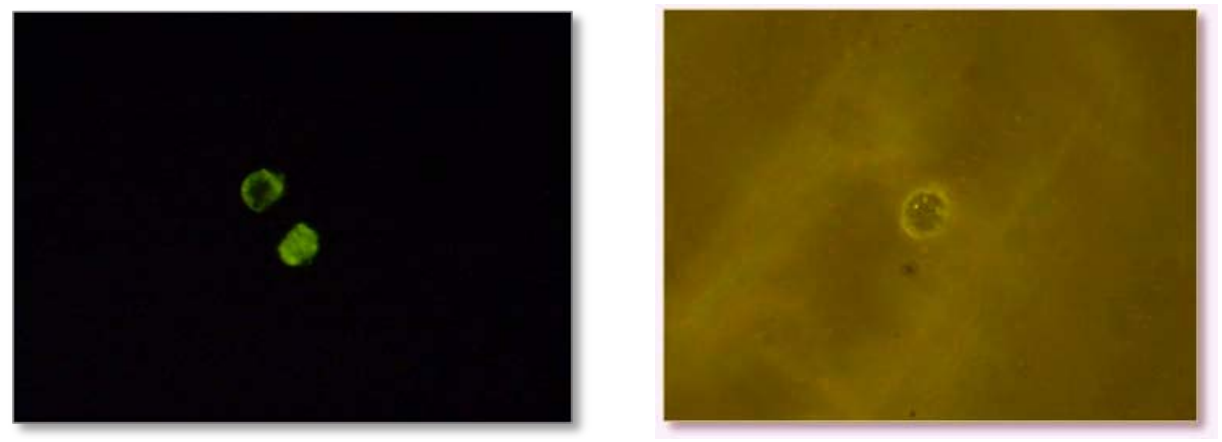

Figura 27. Imágenes del ADN de células del cúmulus $(400$ X) coloreado con el fluorocromo SYBR Green luego de la corrida electroforética (Ensayo Cometa).

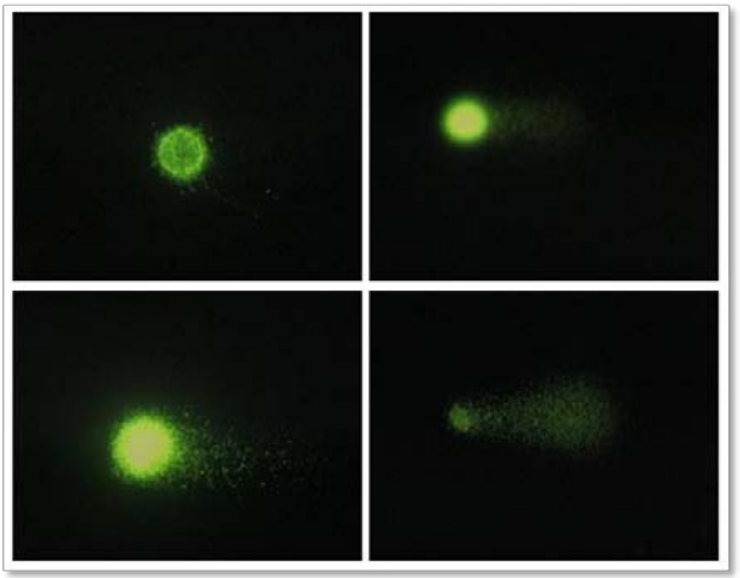


Figura 27a. Clasificación de los Cometas según la longitud de sus colas (400 X).

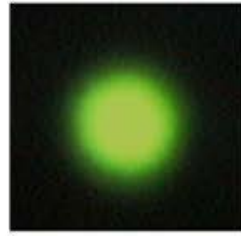

0

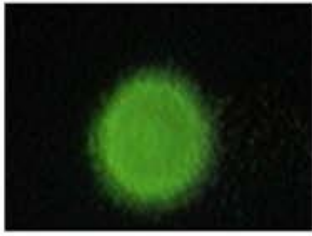

1

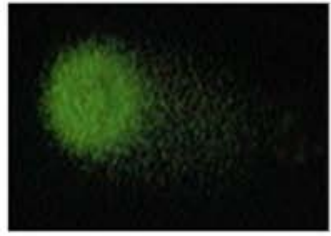

2

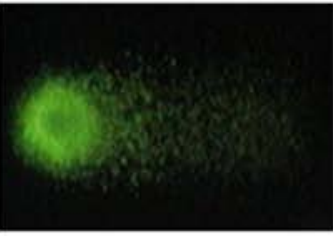

3

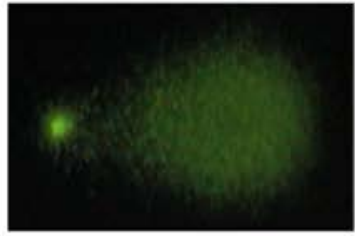

4

Grado 0 (cola no visible), Grado 1 (cometas con cola delgada), Grado 2 (cometas con cola difusa), Grado 3 (cometas con colas bien definidas) y Grado 4 (cometas con una clara disminución en el diámetro de la cabeza y con una cola bien definida). Microscopio de epifluorescencia Olympus BX40 equipado con un filtro de 515-560 nm.

Figura 27b. Determinación del valor de Olive Tail Moment (OTM) mediante el empleo del software Casp ${ }$.
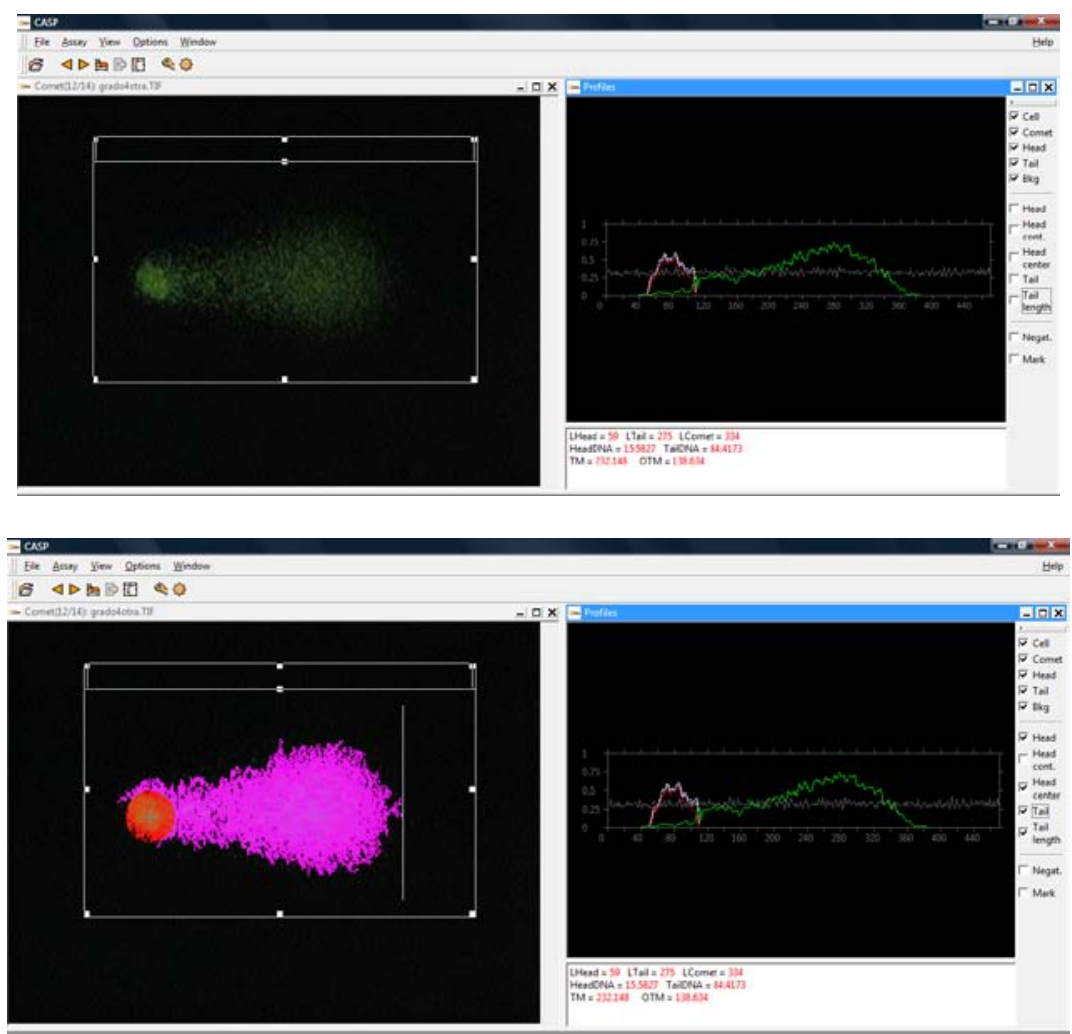


\subsubsection{Ensayo de actividad SOD}

Los extractos enzimáticos de los COC madurados in vitro ( $n=200 /$ tratamiento) fueron obtenidos por el congelamiento-descongelamiento reiterado (2 veces) en agua destilada. La suspensión fue centrifugada a $10.000 \mathrm{~g}$ durante $20 \mathrm{~min}$ a $4^{\circ} \mathrm{C}$ y el sobrenadante fue utilizado para determinar la actividad enzimática total. La actividad SOD fue medida utilizando un Kit comercial (RANSOD, Randox Laboratories Limited, UK). Este método utiliza xantina (Xa) y xantina oxidasa $(\mathrm{XO})$ para generar radicales superóxidos los que reaccionan con 2-(4-iodofenil)3-(4-nitrofenol)-5-cloruro de feniltetrazolium (I.N.T.) que da como resultado formazan de color rojo. La actividad SOD es luego medida en espectrofotómetro por el grado de inhibición de esta reacción. La SOD compite con el I.N.T. por los aniones superóxidos producidos por la XO. Una unidad de actividad SOD es aquella que causa un $50 \%$ de inhibición en la tasa de reducción de I.N.T. bajo las condiciones del ensayo. Las soluciones estándares empleadas se encuentran en el rango de 0,148 a $4,76 \mathrm{U} / \mathrm{ml}$ y se prepararon de acuerdo a las especificaciones del Kit. Las reacciones fueron iniciadas por el agregado de $75 \mu \mathrm{l}$ de la solución de XO (80 U/l) a la solución de reacción (I.N.T. + Xa + muestra o estándar). Las muestras fueron medidas a los 30 segundos y a los 3 minutos de iniciada la reacción a una longitud de onda de 505 nm con un espectofotómetro Hitachi U-2000. Todas las muestras, los blancos y los estándares fueron corridos por triplicado y la actividad SOD fue reportada como Unidades/COC.

\subsubsection{Análisis estadístico}

Se utilizó un diseño experimental completamente aleatorio en bloque. El análisis estadístico de las variables continuas (área de expansión del cúmulus, concentración intracelular de GSH, índice de daño del ADN, Olive Tail Moment y actividad SOD) se realizó mediante una regresión lineal mixta con el procedimiento MIXED de SAS 9.0 (SAS Inst. Inc.). El 
modelo incluyó el efecto aleatorio del bloque (repeticiones $n=4$ a 6) y el efecto fijo del tratamiento (0,3 vs. 0,7 vs. 1,1 vs. $1,5 \mu \mathrm{g} / \mathrm{ml} \mathrm{Zn}$ ). En el caso del área de expansión se utilizó tiempo 0 (T0) como covariable. El análisis estadístico de las variables binomiales (tasa de apoptosis en $\mathrm{CC}$ y porcentaje de $\mathrm{CC}$ con daño en el $\mathrm{ADN}$ ) se realizó mediante una regresión logística con el procedimiento GENMOD de SAS 9.0 (SAS Inst. Inc.). Se utilizó una distribución Binomial y un enlace Logit. El modelo logístico incluyó los efectos descriptos anteriormente (bloque y tratamiento). Las variables continuas se expresan como el promedio \pm ESM. Las variables binomiales están expresadas como porcentaje. Se consideraron efectos significativos a las $p<0,05$ y tendencias a las $p<0,10$ y $p>0,05$.

\subsection{Diseño experimental}

\subsubsection{Efecto del Zinc sobre el área de expansión del cúmulus}

En el Experimento 1 se evaluó el efecto de distintas concentraciones de Zn (Control= 0,3 $\mu \mathrm{g} / \mathrm{ml} ; \mathrm{Zn} 1=0,7 \mu \mathrm{g} / \mathrm{ml} ; \mathrm{Zn} 2=1,1 \mu \mathrm{g} / \mathrm{ml} ; \mathrm{Zn3}=1,5 \mu \mathrm{g} / \mathrm{ml}$ ) en el medio de MIV sobre la expansión del área del cúmulus. Los COC fueron madurados por 24 hs de forma individual en microgotas de $50 \mu \mathrm{l}$ de medio de MIV (4.2.2), y se evaluó la expansión del cúmulus como se describe en 4.2.3. Para este propósito se maduraron in vitro 300 COC. Los COC se colectaron en días diferentes ( $n=5$ repeticiones), 60 COC por día. Los 60 COC fueron distribuidos en 4 tratamientos ( $n=15 /$ tratamiento) y se maduraron en las condiciones definidas en 4.2.2.

\subsubsection{Efecto del Zinc sobre la concentración intracelular de GSH}

En el Experimento 2 se evaluó el efecto de distintas concentraciones de Zn (Control= 0,3 $\mu \mathrm{g} / \mathrm{ml} ; \mathrm{Zn} 1=0,7 \mu \mathrm{g} / \mathrm{ml} ; \mathrm{Zn} 2=1,1 \mu \mathrm{g} / \mathrm{ml} ; \mathrm{Zn} 3=1,5 \mu \mathrm{g} / \mathrm{ml}$ ) en el medio de MIV sobre la 
concentración intracelular de GSH-GSSG en ovocitos y células del cúmulus. Los COC fueron madurados por 24 hs (4.2.2), y se evaluó la concentración total de GSH como se describe en la sección 4.2.4. Para este propósito 800 COC fueron maduraron in vitro con distintas concentraciones de $\mathrm{Zn}$. Los COC fueron colectados en cuatro días diferentes $(\mathrm{n}=4$ repeticiones) y en cada repetición se evaluaron 200 COC (50 COC por tratamiento).

\subsubsection{Efecto del zinc sobre la tasa de apoptosis en células del cúmulus.}

En el Experimento 3 se evaluó el efecto de distintas concentraciones de Zn (Control= 0,3 $\mu \mathrm{g} / \mathrm{ml} ; \mathrm{Zn} 1=0,7 \mu \mathrm{g} / \mathrm{ml} ; \mathrm{Zn} 2=1,1 \mu \mathrm{g} / \mathrm{ml} ; \mathrm{Zn3}=1,5 \mu \mathrm{g} / \mathrm{ml}$ ) en el medio de MIV sobre la apoptosis temprana de células del cúmulus evaluado con Anexina-V-FLUOS. Los COC fueron madurados por 24 hs (4.2.2), y la apoptosis fue evaluada como se describe en 4.2.5. Para este propósito, se maduraron 800 COC repartidos en 4 repeticiones en diferentes días (200 COC por repetición, $50 \mathrm{COC} /$ tratamiento). Se analizó un total de 200 células por tratamiento bajo microscopio de fluorescencia a $400 \mathrm{X}$.

\subsubsection{Efecto del zinc sobre la integridad del ADN de células del cúmulus}

En el Experimento 4 se evaluó el efecto de distintas concentraciones de Zn (Control= 0,3 $\mu \mathrm{g} / \mathrm{ml} ; \mathrm{Zn} 1=0,7 \mu \mathrm{g} / \mathrm{ml} ; \mathrm{Zn} 2=1,1 \mu \mathrm{g} / \mathrm{ml} ; \mathrm{Zn} 3=1,5 \mu \mathrm{g} / \mathrm{ml})$ en el medio de MIV sobre el daño en el ADN de células del cúmulus, evaluado por ensayo cometa. Los COC fueron madurados por 24 hs (4.2.2), y luego se evaluó el daño en el ADN como se describe en 4.2.6. Para este propósito se maduraron 800 COC en cuatro repeticiones $(n=4)$ de días diferentes (200 COC por repetición, 50 COC por tratamiento). Cada grupo de 50 COC fue procesado para analizar al menos 250 células por tratamiento. 


\subsubsection{Efecto del zinc sobre la actividad SOD del COC}

En el Experimento 5 se evaluó el efecto de distintas concentraciones de Zn (Control= 0,3 $\mu \mathrm{g} / \mathrm{ml}$ y $Z \mathrm{n} 3=1,5 \mu \mathrm{g} / \mathrm{ml}$ ) en el medio de MIV sobre la actividad SOD total del COC luego de 24 horas de maduración (4.2.2). La actividad SOD total se determinó como se describe en 4.2.7. Para este propósito, se maduraron 400 COC (200 COC para Control y 200 COC para Zn3). Los COC pertenecientes al mismo tratamiento fueron congelados $\left(-70^{\circ} \mathrm{C}\right)$ en el mismo vial hasta el momento de su análisis.

\subsection{Resultados}

\subsubsection{Efecto del Zinc sobre el área de expansión del cúmulus}

En el Experimento 1, el área de expansión del cúmulus no presentó diferencias significativas entre los COC tratados con Zn (Zn1, Zn2 y Zn3) y el Control (Tabla 1). Por otro lado, no hubo diferencias significativas en el número de células del cúmulus por $\operatorname{COC}$ ( $n=4$ COC por tratamiento) al T0 o después de la MIV (T24) en ninguna de las concentraciones de Zn evaluadas [antes de la MIV= $15100 \pm 1100$; después de la MIV= $15133 \pm 1180$ (Control), 15187

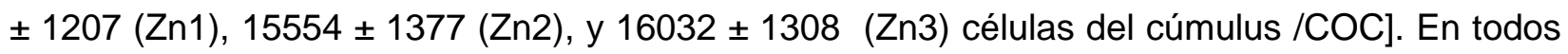
los tratamientos, se evaluó la maduración nuclear de los ovocitos mediante tinción con Hoechts 33342, por la presencia luego de la MIV de la placa metafásica y el cuerpo polar (MII + CP) (2.6). El porcentaje de maduración nuclear se mantuvo en un rango de 90 - $95 \%$ y no presentó diferencias significativas entre las distintas concentraciones de $\mathrm{Zn}$ empleadas y el Control. 
Tabla 1. Expansión del cúmulus 24 horas después de ser madurados con diferentes concentraciones de zinc.

\begin{tabular}{lcc}
\hline Tratamiento $(\mu \mathrm{g} \mathrm{Zn} / \mathrm{ml})$ & Número de COC & Área del cúmulus $\left(\mu \mathrm{m}^{2}\right)$ \\
\hline Control $(0,3 \mu \mathrm{g} \mathrm{Zn} / \mathrm{ml})$ & 75 & $647.616 \pm 35.700$ \\
Zn1 $(0,7 \mu \mathrm{g} \mathrm{Zn} / \mathrm{ml})$ & 75 & $596.716 \pm 35.879$ \\
Zn2 $(1,1 \mu \mathrm{g} \mathrm{Zn/ml})$ & 75 & $541.038 \pm 37.060$ \\
Zn3 $(1,5 \mu \mathrm{g} \mathrm{Zn/ml})$ & 75 & $601.447 \pm 36.869$ \\
\hline
\end{tabular}

No hubo diferencias en el área de expansión entre los distintos tratamientos.

Los COC bovinos se incubaron en medio de MIV sin suplementar (Control= $0,3 \mu \mathrm{g} / \mathrm{ml})$ o suplementados con $\mathrm{Zn}(\mathrm{Zn} 1=0,7 \mu \mathrm{g} / \mathrm{ml}$; $\mathrm{Zn} 2=1,1 \mu \mathrm{g} / \mathrm{ml}$ y Zn3= $1,5 \mu \mathrm{g} / \mathrm{ml}$ de $\mathrm{Zn}$ ).

Todos los valores correspondientes a $\mu \mathrm{m}^{2}$ se expresan como la media \pm ESM (300 COC en 5 repeticiones, 60 COC por repetición, 15 COC por tratamiento en cada repetición).

\subsubsection{Efecto del Zinc sobre la concentración intracelular de GSH}

En el Experimento 2, la concentración intracelular de GSH-GSSG de ovocitos y de células del cúmulus no presentó diferencias significativas en presencia de $1,101,5 \mu \mathrm{g} / \mathrm{ml}$ de $\mathrm{Zn}$ durante la MIV con respecto al Control. Sin embargo la concentración de GSH-GSSG fue menor en presencia de $0,7 \mu \mathrm{g} / \mathrm{ml} \mathrm{Zn}(\mathrm{p}<0,01$; Tabla 2$)$.

\subsubsection{Efecto del zinc sobre la tasa de apoptosis de células del cúmulus}

En el Experimento 3, se evaluó la tasa de apoptosis de las células del cúmulus tratadas con diferentes concentraciones de Zn. La frecuencia de células apoptóticas fue mayor en el grupo Control que en las células incubadas con diferentes concentraciones de $\mathrm{Zn}(p<0,05)$. Existieron diferencias significativas entre el Control y Zn1 $(p<0,05)$, Control y Zn2 $(p<0,01)$, 
Control y Zn3 ( $p<0,0001)$, Zn1 y Zn3 $(p<0,001)$ y Zn2 y Zn3 $(p<0,001)$. No se encontraron diferencias significativas entre Zn1 y Zn 2 (Figura 28).

\subsubsection{Efecto del zinc sobre la integridad del ADN de células del cúmulus}

En el Experimento 4, las CC pertenecientes a COC madurados en presencia de Zn durante la MIV, presentaron una disminución significativa en el índice daño del ADN (IDD) (p< 0,05) (Figura 29). Los resultados de este experimento demostraron además, una mayor proporción de CC Grado 0 (sin daño en el ADN) cuando los COC fueron madurados con el agregado de Zn (Tabla 3). El porcentaje de CC con distintos tipos de daño fue significativamente menor en aquellos COC madurados con 1,1 y $1,5 \mu \mathrm{g} / \mathrm{ml}$ de $\mathrm{Zn}$ con respecto a los madurados con $0,7 \mu \mathrm{g} / \mathrm{ml}$ de $\mathrm{Zn}$ y con medio Control $(p<0,01)$ (Tabla 4). El valor de OTM fue menor en las $\mathrm{CC}$ de $\mathrm{COC}$ madurados con el agregado de $\mathrm{Zn}$ comparado con el grupo Control ( $p<0,0001)$. Sin embargo, los valores de OTM de los COC madurados con distintas concentraciones de Zn fueron similares entre sí (Figura 30).

Tabla 2. Concentración intracelular de GSH/GSSG en ovocitos y células del cúmulus bovinos maduradas con diferentes concentraciones de Zinc.

\begin{tabular}{lcccc}
\cline { 2 - 5 } & Control & Zn1 & Zn2 & Zn3 \\
\hline GSH-GSSG en ovocito (pmol/ovocito) & $3,0 \pm 0,9^{\mathrm{a}}$ & $1,8 \pm 0,5^{\mathrm{b}}$ & $3,7 \pm 0,4^{\mathrm{a}}$ & $4,0 \pm 0,5^{\mathrm{a}}$ \\
& & & & \\
GSH-GSSG en CC (nmol/10 células) & $0,3 \pm 0,05^{\mathrm{a}}$ & $0,2 \pm 0,02^{\mathrm{b}}$ & $0,5 \pm 0,04^{\mathrm{a}}$ & $0,5 \pm 0,04^{\mathrm{a}}$
\end{tabular}

Los valores indicados con diferentes superíndices dentro de cada fila son diferentes $(p<0,01)$.

Los COC bovinos se incubaron en medio de MIV sin suplementar (Control= 0,3 $\mu \mathrm{g} / \mathrm{ml})$ o suplementados con Zn $(\mathrm{Zn} 1=0,7 \mu \mathrm{g} / \mathrm{ml}$; $\mathrm{Zn} 2=1,1 \mu \mathrm{g} / \mathrm{ml}$ y $\mathrm{Zn3}=1,5 \mu \mathrm{g} / \mathrm{ml}$ ). Todos los valores correspondientes a pmol GSH-GSSG/ovocito y nmol GSH-GSSG/10 ${ }^{6}$ células cúmulus se expresan como la media \pm ESM (800 COC en 4 repeticiones, 200 COC por repetición, 50 COC por tratamiento en cada repetición). 
Figura 28. Efecto de diferentes concentraciones de zinc sobre la tasa de apoptosis en células del cúmulus evaluado con Anexina V-FLUOS.

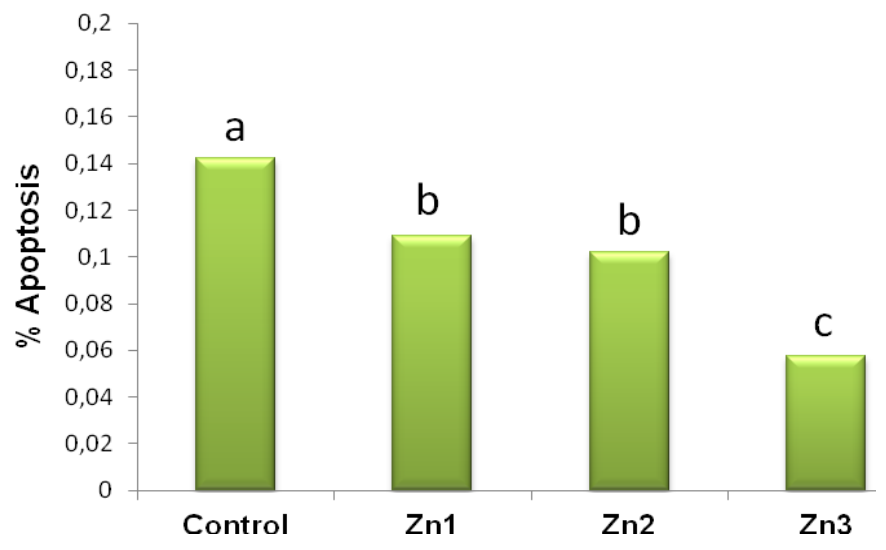

( $a$, b y c) indican diferencias estadísticamente significativas $(p<0,05)$.

Los COC bovinos se incubaron en medio de MIV sin suplementar (Control= 0,3 $\mu \mathrm{g} / \mathrm{ml})$ o suplementados con $\mathrm{Zn}(\mathrm{Zn} 1=0,7 \mu \mathrm{g} / \mathrm{ml}$; $\mathrm{Zn} 2=1,1 \mu \mathrm{g} / \mathrm{ml}$ y $\mathrm{Zn} 3=1,5 \mu \mathrm{g} / \mathrm{ml})$.

Los valores se expresan como porcentaje de apoptosis (Control= 0,142 \%; Zn1= 0,109 \%; Zn2= 0,102 \%; Zn3=0,0577 \%) (800 COC en 4 repeticiones, 200 COC por repetición, 50 COC por tratamiento en cada repetición).

Figura 29. Índice de Daño del ADN en células del cúmulus luego de la MIV con distintas concentraciones de zinc.

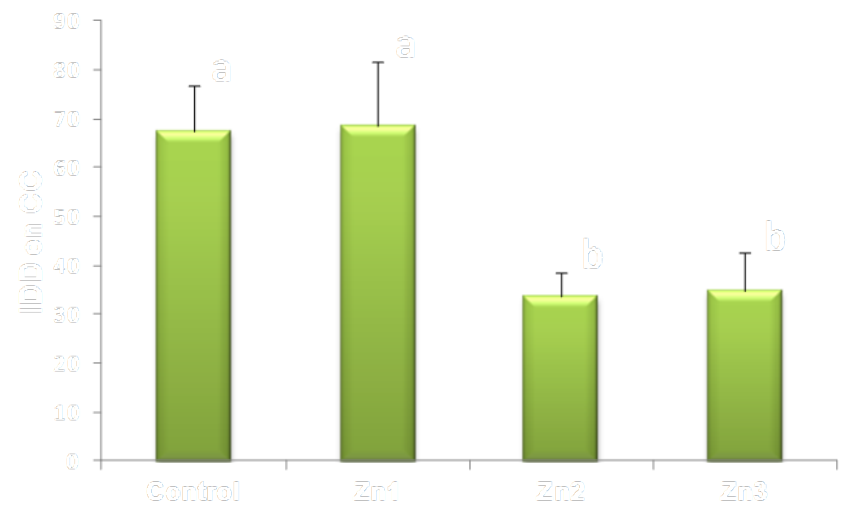

IDD: Índice de Daño del ADN. CC: células del cúmulus. ( $a$, b y c) indican diferencias estadísticamente significativas $(p<0,05)$. Los COC bovinos se incubaron en medio de MIV sin suplementar (Control=0,3 $\mu \mathrm{g} / \mathrm{ml})$ o suplementados con Zn $(\mathrm{Zn} 1=0,7 \mu \mathrm{g} / \mathrm{ml}$; $\mathrm{Zn} 2=1,1 \mu \mathrm{g} / \mathrm{ml}$ y $\mathrm{Zn} 3=1,5 \mu \mathrm{g} / \mathrm{ml})$.

Todos los valores correspondientes al IDD en CC (67,52 $\pm 9,32 ; 68,52 \pm 13,34 ; 33,80 \pm 4,89$ y 34,65 $\pm 7,92$ para Control, Zn1, Zn2 y Zn 3 respectivamente) se expresan como la media \pm ESM (800 COC en 4 repeticiones, 200 COC por repetición, 50 COC por tratamiento en cada repetición). 
Tabla 3. Porcentaje de células del cúmulus con o sin daño en el ADN de acuerdo a la concentración de zinc en el medio de cultivo.

\begin{tabular}{lcc}
\hline Tratamiento & CC con daño en el ADN & CC sin daño en el ADN \\
\hline & $\%$ & $\%$ \\
Control & $38,26^{\mathrm{a}}$ & $61,73^{\mathrm{a}}$ \\
Zn1 & $41,41^{\mathrm{a}}$ & $58,59^{\mathrm{a}}$ \\
Zn2 & $20,86^{\mathrm{b}}$ & $79,14^{\mathrm{b}}$ \\
Zn3 & $19,23^{\mathrm{b}}$ & $80,77^{\mathrm{b}}$ \\
\hline
\end{tabular}

CC: células del cúmulus.

Los valores con distintas letras dentro de cada columna son estadísticamente diferentes $(p<0,01)$.

Los COC bovinos se incubaron en medio de MIV sin suplementar (Control= 0,3 $\mu \mathrm{g} / \mathrm{ml})$ o suplementados con Zn $(\mathrm{Zn} 1=0,7 \mu \mathrm{g} / \mathrm{ml}$; $\mathrm{Zn} 2=1,1 \mu \mathrm{g} / \mathrm{ml}$ y Zn3= $1,5 \mu \mathrm{g} / \mathrm{ml})$.

Los datos se expresan como el porcentaje de 800 COC en cuatro repeticiones, 200 COC por réplica, 50 COC por tratamiento.

Tabla 4. Daño del ADN en células del cúmulus maduradas in vitro con diferentes concentraciones de zinc.

\begin{tabular}{lccccc} 
& \multicolumn{5}{c}{ Grado de Daño (Grado) } \\
\cline { 2 - 6 } & 0 & 1 & 2 & 3 & 4 \\
\hline Control $^{\text {a }}$ & 64,92 & 14,76 & 11,38 & 5,69 & 3,25 \\
Zn1 $^{\text {a }}$ & 58,90 & 22,47 & 13,74 & 3,54 & 1,35 \\
Zn2 $^{\text {b }}$ & 78,58 & 12,60 & 5,85 & 2,27 & 0,7 \\
Zn3 $^{\text {b }}$ & 80,01 & 11 & 5,52 & 2,37 & 1,1 \\
\hline
\end{tabular}

Los valores indicados con diferentes superíndices son diferentes $(p<0,01)$.

Los COC bovinos fueron incubados en medio MIV sin suplementar (Control, 0,3 $\mu \mathrm{g}$ de Zn/ml); 0,7 $\mu \mathrm{g} \mathrm{de} \mathrm{Zn/ml} \mathrm{(Zn1);} \mathrm{1,1 \mu g} \mathrm{de} \mathrm{Zn/ml}$ (Zn2); y $1,5 \mu \mathrm{g}$ de $\mathrm{Zn} / \mathrm{ml}(\mathrm{Zn} 3)$.

Células evaluadas: Control= 1300; Zn1 = 1411; Zn2 = 1200 y Zn3 =1203.

Los valores para grado de daño en células del cúmulus están expresados como porcentaje. (800 COC en cuatro replicas). 
Figura 30. Efecto de diferentes concentraciones de zinc sobre el valor de Olive Tail Moment (OTM) en células del cúmulus.

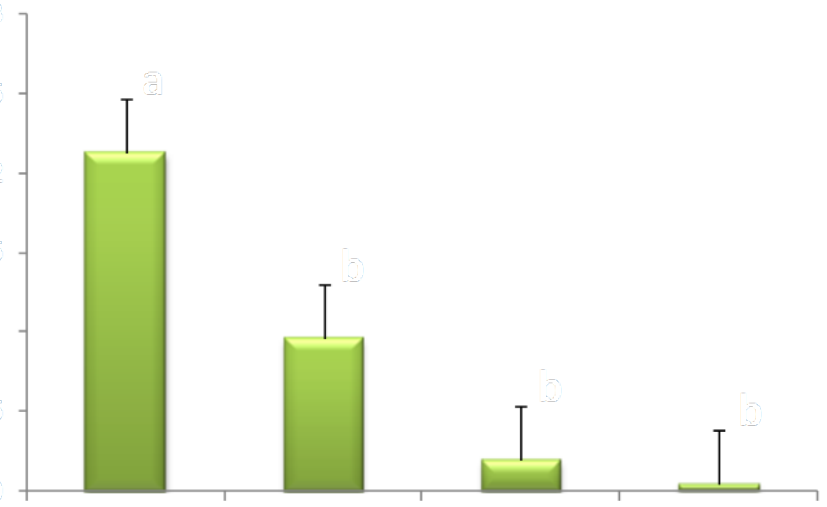

(a, b y c) indican diferencias estadísticamente significativas $(p<0,0001)$.

Los COC bovinos se incubaron en medio de MIV sin suplementar (Control= $0,3 \mu \mathrm{g} / \mathrm{ml})$ o suplementados con $\mathrm{Zn}(\mathrm{Zn} 1=0,7 \mu \mathrm{g} / \mathrm{ml}$; $\mathrm{Zn} 2=1,1 \mu \mathrm{g} / \mathrm{ml}$ y Zn3= $1,5 \mu \mathrm{g} / \mathrm{ml}$ ).

Los valores se expresan como valor de OTM \pm ESM (Control= 2,134 $\pm 0,345 ; \mathrm{Zn} 1=0,960 \pm 0,345 ; \mathrm{Zn2}=0,199 \pm 0,345 ; \mathrm{Zn3}=0,046$ $\pm 0,345$ ) (800 COC en 4 repeticiones, 200 COC por repetición, 50 COC por tratamiento en cada repetición).

\subsubsection{Efecto del zinc sobre la actividad SOD del COC}

En el Experimento 5, la actividad SOD de COC madurados con el agregado de Zn (Zn3) fue mayor que en el grupo Control (Control= 3,9 \pm 0,39; Zn3=5,1 \pm 0,43 Unidades SOD/COC 10 $\left.{ }^{-3} ; p<0,05\right)$ (Figura 31). 
Figura 31. Actividad SOD del complejo ovocito-cúmulus luego de la MIV con y sin el agregado de zinc.

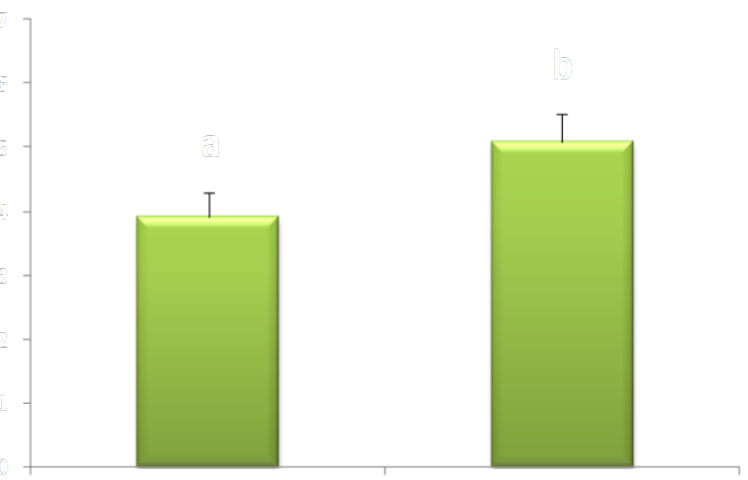

(a y b) indican diferencias significativas $(p<0,05)$.

Los COC bovinos se incubaron en medio de MIV sin suplementar (Control= 0,3 $\mu \mathrm{g} / \mathrm{ml} \mathrm{Zn)} \mathrm{o} \mathrm{suplementado} \mathrm{con} \mathrm{1,5} \mu \mathrm{g} / \mathrm{ml} \mathrm{Zn} \mathrm{(Zn3).}$ Los valores se expresan como la media \pm ESM (400 COC, 200 COC por tratamiento).

\subsection{Discusión}

El complejo ovocito-cúmulus luego de la MIV sufre cambios morfológicos y funcionales como la formación de una matriz extracelular que se ubica entre las células del cúmulus y produce la expansión del mismo. El componente principal de la matriz extracelular del cúmulus expandido es el AH (Yudin y col., 1988; Salustri y col., 1989). La cantidad de AH sintetizado se encuentra estrechamente relacionada con el grado de expansión del cúmulus (Chen y col., 1992,1996; Furnus y col., 1998). Se ha demostrado, que la síntesis de novo de AH por parte de las células del cúmulus es estimulada in vitro por la $\mathrm{FSH}$, y que componente/s del suero posibilitan la retención del mismo dentro del complejo ovocito-cúmulus (Eppig, 1980; Chen y col., 1992). 
Nuestro estudio demostró que el agregado de distintas concentraciones de Zn al medio de cultivo no alteró el grado de expansión del cúmulus luego de 24 horas de MIV. La expansión del cúmulus es un proceso esencial que facilita el desprendimiento del COC de la pared del folículo, la extrusión durante la ovulación y la captura del COC por las fimbrias del oviducto (Meizel, 1985; Chen y col., 1993; Tsafriri, 1995; Larsen y col., 1996; Hess y col., 1999). Por otra parte, la expansión del cúmulus puede influir en una gran variedad de cambios fundamentales para el desarrollo embrionario posterior (Chen y col., 1993; Vanderhyden, 1993; Furnus y col., 1998). En condiciones in vitro, la FSH produce un incremento en la síntesis de enzimas claves para la producción de AH como la HAS2 y la prostaglandinasintetasa endoperoxidasa 2 (PTGS2), así como también de proteínas que intervienen en la organización de la matriz extracelular como el factor de necrosis tumoral inducido por la proteína 6 (TGS6) y la pentraxina 3 (PTX3) (Richards y col., 2002; Vanderhyden, 2002; Nemcová y col., 2007). El AH sintetizado por la HAS2 luego del pico de LH in vivo o en respuesta a la FSH in vitro, es organizado en elementos fibrilares retorcidos o en espiral interconectados entre sí para formar una red similar a una malla (Yudin y col., 1988). Hasta el momento, se han identificado tres proteínas esenciales para la adecuada formación y estabilidad de la matriz extracelular del COC de ratón: el Inhibidor de la inter-atripsina (lal), el TSG6, y la PTX3 (Scarchilli y col., 2007). Si bien, aún no se ha dilucidado completamente, cómo estas proteínas influyen e integran su acción en el montaje de la matriz, la falta de algunas de ellas provoca la inestabilidad de la misma y la consecuente subfertilidad (Scarchilli y col., 2007). Recientemente, Tian y Diaz (2012) propusieron al Zn como cofactor esencial para el correcto funcionamiento de los factores de transcripción pSMAD-2 y pSMAD-3 que, en presencia del Factor de Crecimiento Epidérmico (Epidermal Growth Factor, EGF) estimulan la transcripción de HAS2, PTGS2, PTX3 y TSG6 y por lo tanto, la expansión del cúmulus en ovocitos de ratón. En nuestro trabajo, el grado de expansión del cúmulus no se 
modificó en presencia de Zn lo que podría explicarse por la ausencia del EGF en el medio de MIV.

La concentración total de GSH/GSSG fue significativamente menor, en ovocitos y células del cúmulus, únicamente cuando se utilizó para la MIV 0,7 $\mu \mathrm{g} / \mathrm{ml} \mathrm{Zn}$ (Zn1). Estudios previos, indican que una disminución importante de $\mathrm{Zn}$ intracelular tiene como consecuencia una reducción en el contenido de GSH (Krezel y col., 2003). La relación entre el Zn y el GSH ha sido exhaustivamente estudiada (Kojima-Yuasay col., 2003; Cortese y col., 2008; Cortese-Krott y col., 2009). El GSH es un ligando biológico que cuando la concentración de Zn es deficiente se acopla a él formando complejos binarios o terciarios a pH 7.4 (Maret, 1994). Además, la complejidad molecular del sistema zinc/glutatión y su dependencia con el pH le confiere propiedades de transportador biológico (carrier) para el Zn (O'Halloran, 1993). El GSH en el ovocito es importante para la expansión in vitro del cúmulus oophorus y para la protección del desarrollo embrionario hasta el estadio de blastocisto por su acción antioxidante (Furnus y col. 1998; Ho, 2004). Además, altas concentraciones de GSH durante la MIV mejoran las tasas de desarrollo hasta el estadio de blastocisto y la calidad de los embriones aptos para ser cripopreservados y luego transferidos (de Matos y col., 1996; Furnus y col., 2008).

Además de su importante papel en la protección contra ROS y agentes tóxicos, el GSH interviene en procesos específicos de la reproducción y del desarrollo embrionario temprano. La capacidad de los ovocitos de hámster para inducir la descondensación nuclear del espermatozoide varía según su etapa de maduración y se correlaciona con altos niveles de GSH (Perreault y col., 1988). El bloqueo de su síntesis impide la descondensación nuclear del espermatozoide luego de la fecundación (Calvin y col., 1986) y la suplementación del medio de maduración in vitro con uno de sus precursores (cisteína) aumenta el contenido de GSH de los ovocitos porcinos y la posterior formación de los pronúcleos masculinos (Yoshida y col., 1993). 
El contenido de GSH de un ovocito se encuentra altamente correlacionado con la presencia de su cúmulus (Sawai y col., 1997). Varios autores describieron una menor concentración de GSH luego de la MIV en ovocitos denudados respecto a aquellos madurados con su cúmulus (de Matos y col., 1997; Luciano y col., 2005; Maedomari y col., 2007). La concentración intracelular de GSH es el producto del balance entre su uso y su síntesis, y se encuentra modificada por diferentes condiciones intracelulares (Dickinson y Forman, 2002).

La presencia de metales pesados, la exposición a ROS o compuestos que puedan generarlas incrementan el contenido de GSH producto de un aumento en su tasa de síntesis (Woods y Ellis, 1995; Rahman y col., 1996; Dickinson y Forman, 2002). El Zn también aumenta los niveles de este tiol al inducir la expresión de la glutamato-cisteínaligasa (enzima limitante en la síntesis de GSH). Cortese y sus colaboradores (2008) demostraron que la suplementación con sulfato de $\mathrm{Zn}$ en el medio de cultivo celular induce la expresión de la glutamatocisteinaligasa, llegando a la conclusión que la concentración celular de Zn controla la síntesis de GSH. En base a los resultados obtenidos, podríamos decir que cuando las concentraciones de Zn son "adecuadas" durante la MIV, es posible garantizar al menos en parte, una reserva "apropiada" de GSH en el ovocito y CC bovino.

El rol antioxidante del Zn podría ser un mecanismo importante en el mantenimiento de la integridad del $A D N$ en los $C O C$, previniendo el daño oxidativo del ADN de las células del cúmulus. Kincaid (1999), estableció como deficientes a aquellos animales con una zinquemia inferior a 0,8 $\mu \mathrm{g} / \mathrm{ml}$ de $\mathrm{Zn}$, y normales cuando el $\mathrm{Zn}$ en sangre era igual o superior a este valor. Si bien, como se mencionó anteriormente, el mecanismo exacto por el cual el Zn evita el daño oxidativo no es del todo claro, la alteración de su estatus intracelular suprime la capacidad antioxidante de células cultivadas in vitro (Ho y Ames, 2002). En el presente estudio, el daño en la integridad del ADN de las células del cúmulus luego de la maduración in vitro se redujo 
cuando la concentración de $\mathrm{Zn}$ fue de 1,1 y 1,5 $\mu \mathrm{g} / \mathrm{ml}$ de $\mathrm{Zn}$, concentraciones consideradas como adecuadas por Kincaid (1999). Ho (2004) demostró que el sulfato de Zn añadido al cultivo celular in vitro puede prevenir la muerte celular. Estudios realizados in vivo mostraron un aumento en la oxidación de proteínas y en el daño del ADN en leucocitos, neumocitos y hepatocitos de rata, y en hepatocitos de mono deficientes de Zn (Taylor y col., 1988; Olin y col., 1993; Oteiza y col., 2000; Song y col., 2009). Además, la suplementación en humanos y ratas por períodos prolongados con este mineral garantiza una mayor protección contra la muerte celular y el daño en el ADN (Emonet-Piccardi y col., 1998; Chimienti y col., 2001). Si bien, el mecanismo de acción del Zn en los COC debe ser explorado con mayor profundidad, el presente estudio pone de manifiesto que concentraciones adecuadas de Zn "protegen" a estas células contra el daño en el ADN. El Zn posee un conocido desempeño como agente antioxidante y su capacidad para retardar los procesos oxidativos es reconocida desde hace muchos años (Powell, 2000; Chihuailaf y col., 2002). Si bien, se han identificado algunos mecanismos por los cuales el Zn ejerce un efecto protector contra el estrés oxidativo, su modo de acción permanece en parte desconocido (Chimienti y col., 2001). La función antioxidante de este mineral puede estar relacionada con varios factores. En primer lugar, el $\mathrm{Zn}$ es un componente esencial de la enzima Cu/Zn- SOD, una de las primeras líneas de defensa celular contra las especies reactivas del oxígeno (Ho, 2004). Por otro lado, previene la oxidación de los grupos sulfidrilo de las proteínas y ejerce un rol antagónico sobre los metales de transición prooxidantes, como el hierro o el cobre, al competir por sus sitios de unión a las membranas (Kelly y col., 1986; Washabaugh y Collins, 1986; Conte y col., 1996; Powell, 2000; Ho, 2004). Un tercer mecanismo por el que el Zn actúa como protector es su participación en el metabolismo de la metalotioneína. Esta proteína de bajo peso molecular actúa como un potente eliminador de radicales hidroxilo. El Zn puede inducir la expresión de metalotioneína, elevando 
su concentración citoplasmática, a través de la activación de su factor de transcripción (metal transcription factor 1, MTF-1) (Ho, 2004).

La apoptosis es un proceso fisiológico que conduce a una muerte celular programada. Este fenómeno es crítico durante la embriogénesis y fundamental para mantener la homeostasis tisular (Schrantz y col., 1999). Morfológicamente se caracteriza por la pérdida del volumen celular, expresión de fosfatidilserina en la superficie externa de la membrana plasmática, contracción celular, condensación de la cromatina y fragmentación del ADN (Wyllie y col., 1980; Cohen, 1993). Existen una gran variedad de estímulos y condiciones, tanto fisiológicas como patológicas, que pueden desencadenar la apoptosis. Este fenómeno que se inicia por diferentes vías depende, en todos los casos, de la activación de un grupo de proteasas llamadas caspasas (Czerski y Nuñez, 2004; Elmore, 2007). Entre estas enzimas se encuentra la caspasa 3 responsable de desencadenar la fragmentación del ADN, la degradación de las proteínas nucleares y del citoesqueleto, la formación de cuerpos apoptóticos y la expresión de ligandos para receptores de células fagocíticas (Martinvalet y col., 2005; Elmore, 2007). Existen trabajos que sugieren la intervención de cationes divalentes en la regulación de la apoptosis en células de mamíferos (Schrantz y col., 1999). Se ha demostrado tanto in vivo como in vitro que una reducción marcada de $\mathrm{Zn}$ aumenta la apoptosis, mientras que su suplementación puede proteger a las células de diversas moléculas proapoptóticas previniendo así la muerte celular programada (Cohen y Duke, 1984; Martin y col., 1991; Bicknell y col., 1994; Sunderman, 1995; Chimienti y col., 2003). El efecto inhibitorio directo del Zn sobre la apoptosis se desarrolla mediante dos mecanismos; durante los estadios tempranos de la apoptosis el Zn inhibe la caspasa 3, mientras que en etapas más avanzadas suprime las endonucleasas dependientes de $\mathrm{Mg}^{++} \mathrm{y} \mathrm{Ca}^{++}$responsables de causar la fragmentación del ADN (Perry y col., 1997; Chai y col., 1999; Truong-Tran y col., 2000; Chimienti y col., 2003). Por otra 
parte, muchos de los agentes inductores de apoptosis son sustancias oxidantes o estimuladoras del metabolismo celular oxidativo (Freeman y Crapo, 1982), por lo que el Zn también posee un importante rol antiapoptótico por su papel protagónico como agente antioxidante. En el presente estudio, las células del cúmulus tratadas con Zn durante el cultivo in vitro presentaron una disminución en su tasa de apoptosis a medida que aumentó la concentración de Zn en el medio. Las células del cúmulus suplementadas con 1,5 $\mu \mathrm{g} / \mathrm{ml}$ de Zn (concentración plasmática normal en el bovino) presentaron la tasa de apoptosis más baja. Por lo tanto, los presentes resultados indican que concentraciones de $\mathrm{Zn}$ similares a las concentraciones plasmáticas normales disminuyen la tasa de apoptosis de las células del cúmulus durante la maduración in vitro.

La actividad SOD en los COC aumentó cuando fueron madurados con Zn. La Cu/Zn-SOD puede perder su moléculas de $\mathrm{Zn}$ con mucha mayor facilidad que las de cobre (Cu), ya que esta enzima posee aproximadamente una afinidad 7000 veces menor por el $\mathrm{Zn}$ que por el $\mathrm{Cu}$. La deficiencia de $\mathrm{Zn}$ aumenta dramáticamente la reducción del sitio activo del $\mathrm{Cu}$ afectando las propiedades redox del mismo. La suplementación con $\mathrm{Zn}$ al medio de cultivo in vitro de neuronas motoras cuya SOD es deficiente de $\mathrm{Zn}$ restaura su actividad. Esto demuestra que la enzima SOD deficiente de $\mathrm{Zn}$ puede incorporar este metal a su molécula en un medio in vitro y actuar como una Cu/Zn-SOD normal. La pérdida de la función de la Cu/Zn-SOD trae importantes consecuencias funcionales, aumentando la apoptosis y reduciendo la supervivencia celular (Estévez y col., 1999; Pias y col., 2003; Roberts y col., 2007; Srivastava y col., 2007). El aumento de la actividad SOD provocado en respuesta al agregado de $\mathrm{Zn}$ al medio de MIV, podría ser uno de los mecanismos involucrados en la disminución de la tasa de apoptosis en las CC. Probablemente, la mayor actividad observada en los COC suplementados con Zn se deba en parte a una mayor actividad Cu/Zn-SOD, dado el rol que cumple este mineral en la actividad de la enzima. 
En conclusión, los resultados de este estudio muestran que: 1) el agregado de $\mathrm{Zn}$ al medio de MIV no modificó la expansión del cúmulus; 2) la suplementación con Zn no modificó la concentración intracelular de GSH/GSSG en ovocitos y células del cúmulus excepto cuando se utilizó una concentración de $0,7 \mu \mathrm{g} / \mathrm{ml} \mathrm{Zn}$; 3) la tasa de apoptosis en las células del cúmulus disminuyó conforme aumentó la concentración de Zn en el medio de maduración; 4) el porcentaje de CC sin daño en el ADN fue menor cuando se cultivaron en presencia de 1,1 y 1,5 $\mu \mathrm{g} / \mathrm{ml}$ de $\mathrm{Zn}$, igual comportamiento presentó el grado de daño del ADN siendo las células menos afectadas aquellas cultivas en 1,1 y $1,5 \mu \mathrm{g} / \mathrm{ml}$ de $\mathrm{Zn}$; 5) la actividad SOD en los COC aumentó con el agregado de $1,5 \mu \mathrm{g} / \mathrm{ml}$ de $\mathrm{Zn}$ en el medio de MIV; 6) nuestros resultados sugieren que el Zn podría actuar como un factor importante durante la maduración in vitro, mejorando el estatus antioxidante del COC bovino. 
Capitulo 3 


\section{Efecto de distintas concentraciones de $\mathrm{Zn}$ sobre la capacidad} de desarrollo de los ovocitos hasta el estadio preimplantacional de blastocisto.

\subsection{Introducción}

La maduración del ovocito se define generalmente como el período comprendido entre el primer y segundo arresto meiótico, e implica modificaciones nucleares y citoplasmáticas coordinadas (Tosti, 2006). Estas modificaciones son el resultado de procesos altamente complejos regulados por una serie de eventos moleculares secuenciales (Whitaker y Patel, 1990; Masui, 1996; Whitaker, 1996). La maduración nuclear se caracteriza por la disolución de la membrana nuclear (vesícula germinal), la condensación de la cromatina formando cromosomas bivalentes distinguibles, la separación de los cromosomas homólogos, la emisión del primer cuerpo polar, y la detención en metafase II con los cromosomas alineados en el huso acromático (Moor y col., 1992; Fan y Sun, 2004). La maduración citoplasmática es un proceso menos comprendido, e involucra cambios en la expresión de proteínas responsables del ciclo celular, la reubicación de gránulos corticales, modificaciones en la transcripción de ARNm y la modificación de la permeabilidad de la membrana plasmática, entre otros (Hake y Richter, 1997; Carroll, 2000; Cuomo y col., 2005; Tosti, 2006). Durante este fenómeno, gran cantidad del 
ARNm acumulado durante la fase de crecimiento del ovocito será utilizado en la síntesis de proteínas necesarias para el proceso de fecundación y desarrollo embrionario (Eppig, 1996; Singh y col., 1997).

La maduración del ovocito es un fenómeno sumamente crítico del cual depende la capacidad de desarrollo embrionario posterior (Krisher, 2004; Watson, 2007). Sólo los ovocitos que han madurado correctamente (maduración nuclear y citoplasmática) pueden ser fecundados, desarrollar normalmente hasta el estadio preimplantacional de blastocisto y dar origen a fetos viables (Moor y Trounson, 1977; Schroeder y Eppig, 1984; Gil Corbalán, 2001). La maduración es el resultado de una compleja interacción entre el ovocito, las células del cúmulus y el medio ambiente que lo rodea (Moor y col., 1998). En condiciones in vitro, el medio de MIV representa el entorno del ovocito y de su composición depende en gran medida, su capacidad de desarrollo posterior (Abeydeera, 2002; Martinez Madrid, 2002).

Se sabe que la deficiencia de $\mathrm{Zn}$ puede alterar algunos de estos eventos por lo que el aporte adecuado de este mineral debería ser garantizado durante este proceso (Sun y col., 2007; Kambe y col., 2008; Kim y col., 2011; Tian y Diaz, 2012). El Zn participa en la estabilidad y en la función génica (Dreosti, 2001), forma parte de más de 3000 factores de transcripción y más de 300 enzimas incluyendo la Cu/Zn-SOD y varias proteínas involucradas en la reparación del ADN (Prasad, 1998, 2003; Prasad y Kucuk, 2002). Se ha descripto además, que la disponibilidad de $\mathrm{Zn}$ puede influir en las funciones celulares y en el desarrollo embrionario (Falchuk, 1998; Hostetler y col., 2003). La deficiencia de este mineral en machos produce hipogonadismo, oligospermia y alteraciones de la esteroideogenésis (Kumar y col., 2006; Yamaguchi y col., 2009) mientras que en hembras afecta el ciclo estral e incrementa el riesgo de abortos espontáneos (Graham y col., 1994). Kim y colaboradores (2010) observaron que si bien los ovocitos con una concentración intracelular de Zn muy baja son capaces de ser 
fertilizados, es poco probable que alcancen el estadio de blastocisto. Este trabajo demuestra claramente que los ovocitos de ratón deficientes de $\mathrm{Zn}$ presentan un potencial de desarrollo embrionario gravemente comprometido.

En consecuencia, se diseñaron una serie de experimentos con el fin de estudiar el efecto del agregado de diferentes concentraciones de Zn durante la MIV, sobre el desarrollo embrionario posterior hasta el estadio de blastocisto.

\subsection{Material y métodos}

\subsubsection{Complejos Ovocito-Cúmulus (COC)}

La obtención de los ovocitos se llevó a cabo como se describe previamente (4.2.1). Las repeticiones de cada experimento $(n=6)$ se realizaron en diferentes días y en cada día se obtuvieron 200 COC, utilizando 50 COC por tratamiento.

\subsubsection{MIV/ FIV/CIV}

Los medios y procedimientos utilizados para la MIV, la FIV y el CIV corresponden a los descriptos previamente en $2.3,2.4$ y 2.5 respectivamente. El medio de MIV fue suplementado con Zn de modo de alcanzar las siguientes concentraciones: Zn1) $0,7 \mu \mathrm{g} / \mathrm{ml} \mathrm{Zn}$; Zn2) $1,1 \mu \mathrm{g} / \mathrm{ml}$ $\mathrm{Zn} ; \mathrm{Zn} 3) \mathbf{1 , 5} \mu \mathrm{g} / \mathrm{ml} \mathrm{Zn}$. El medio Control corresponde al medio de MIV sin agregado de Zn (0,3

$\mu \mathrm{g} / \mathrm{ml} \mathrm{Zn)} \mathrm{(3.3.1).} \mathrm{Al} \mathrm{finalizar} \mathrm{el} \mathrm{cultivo,} \mathrm{los} \mathrm{embriones} \mathrm{fueron} \mathrm{evaluados} \mathrm{para} \mathrm{determinar} \mathrm{su}$ estado morfológico de desarrollo con un microscopio invertido (Nikon, Diaphot). 


\subsubsection{Número de células por blastocisto al Día 8}

Los blastocistos de Día 8 se fijaron en formaldehido al 4 \% luego de haber sido lavados 3 veces en PBS con $1 \%$ de PVP. Los embriones se incubaron con Triton X-100 al $1 \%$, se colorearon con Hoecht 33342 y se montaron con glicerol entre portaobjeto y cubreobjeto. El número total de células de los blastocistos (a Día 8, Grado 1) se determinó contando el numero de núcleos con un microscopio de epifluorescencia a 40 X y con filtro de excitación de 365 nm, filtro de barrido de $400 \mathrm{~nm}$ y un filtro de emisión de $400 \mathrm{~nm}$.

\subsubsection{Análisis estadístico}

Se utilizó un diseño experimental completamente aleatorio en bloque. El análisis estadístico de las variables binomiales (tasa de clivaje, tasa de blastocisto y tasa de hatching) se realizó mediante una regresión logística con el procedimiento GENMOD de SAS 9.0 (SAS Inst. Inc.). Se utilizó una distribución Binomial y un enlace Logit. El modelo logístico incluyó los efectos del bloque $(n=6)$ y del tratamiento $(0,3$ vs. 0,7 vs. 1,1 vs. $1,5 \mu \mathrm{g} / \mathrm{ml} \mathrm{Zn})$. El conteo de células por embrión se analizó mediante una regresión Poisson con el procedimiento GENMOD de SAS 9.0 (SAS Inst. Inc.). Se utilizó una distribución Poisson y un enlace Log. El modelo de regrsión Poisson incluyó los efectos descriptos anteriormente. Las variables continuas se expresan como el promedio \pm ESM. Las variables binomiales están expresadas como porcentaje. Se consideraron efectos significativos a las $p<0,05$ y tendencias a las $p<0,10$ y $p$ $>0,05$. 


\subsection{Diseño experimental}

5.3.1 Efecto del Zinc sobre la capacidad de desarrollo de los ovocitos hasta el estadio preimplantacional de blastocisto

En el Experimento 6 se evaluó el efecto de distintas concentraciones de Zn (Control= 0,3 $\mu \mathrm{g} / \mathrm{ml} ; \mathrm{Zn} 1=0,7 \mu \mathrm{g} / \mathrm{ml} ; \mathrm{Zn} 2=1,1 \mu \mathrm{g} / \mathrm{ml} ; \mathrm{Zn} 3=1,5 \mu \mathrm{g} / \mathrm{ml}$ ) en el medio de maduración in vitro sobre la capacidad de desarrollo posterior hasta el estadio de preimplantacional de blastocisto. Para este propósito, un total de 1265 COC obtenidos en 6 días diferentes fueron madurados in vitro con distintas concentraciones de Zn. La tasa de clivaje se evaluó a las 48 horas luego de la inseminación. La tasa de blastocistos incluye aquellos embriones que progresaron hasta el estadio de blastocisto expandido o blastocisto eclosionado al Día 8. El porcentaje de eclosión (hatching) se evaluó al Día 8.

5.3.2 Efecto del Zinc sobre la velocidad de desarrollo de los ovocitos hasta el estadio preimplantacional de blastocisto

En el Experimento 7 se evaluó la velocidad de desarrollo hasta el estadio de blastocisto de los ovocitos madurados con distintas concentraciones de $\mathrm{Zn}$. Los datos fueron obtenidos a partir de los embriones cultivados en el Experimento 6.

\subsubsection{Efecto del Zinc sobre el número de células por blastocisto a Día 8}

En el Experimento 8 se analizó el efecto del Zn sobre el número promedio de células por blastocisto al Día 8 de cultivo. El número de células se evaluó sobre un total de 76 embriones, (3 repeticiones) obtenidos en el Experimento 6. 


\subsection{Resultados}

\subsubsection{Efecto del Zinc sobre la capacidad de desarrollo de los ovocitos hasta el estadio preimplantacional de blastocisto}

En el Experimento 6 la tasa de clivaje no presentó diferencias significativas entre el grupo Control y las distintas concentraciones de $\mathrm{Zn}$ empleadas. Sin embargo, los porcentajes de blastocistos fueron significativamente más altos para los ovocitos madurados en Zn2 y Zn3 que en el Control $(p<0,01)$. Las diferencias en la tasa de blastocistos, entre el grupo Control y Zn1 no fueron significativas (Tabla 5). La tasa de blastocistos se incrementó un 6,6 \% por cada aumento de $0,1 \mu \mathrm{g} / \mathrm{ml} \mathrm{Zn}$ en el medio de MIV $(p<0,001)$.

El porcentaje de hatching, fue mayor en los grupos suplementados con Zn que en el grupo Control $(p<0,001)$, observándose diferencias significativas entre el grupo Control y Zn1 $(p<0,05)$; Control y Zn2 ( $<<0,0001)$; Control y Zn3 $(p<0,05)$; Zn1 y Zn2 $(p<0,01)$ y Zn2 y Zn3 $(p<0,01)$. No se encontraron diferencias entre Zn1 y Zn 3 (Figura 32).

5.4.2 Efecto del Zinc sobre la velocidad de desarrollo de los ovocitos hasta el estadio preimplantacional de blastocisto

En el Experimento 7, el porcentaje de embriones que alcanzaron el estadio de blastocisto en el Día 6 de cultivo, no mostró diferencias significativas entre el grupo Control y los tratados con Zn. Sin embargo, el porcentaje de blastocistos en el Día 7 fue significativamente más alto para los ovocitos madurados con Zn3 con respecto al Control $(p<0,05)$; no encontrándose

diferencias entre el Control y; Zn 1 y Zn2. En el grupo Zn3 la totalidad de los blastocistos se desarrollaron entre el Día 6 y 7 (Tabla 6). 
Tabla 5. Capacidad de desarrollo de ovocitos bovinos madurados in vitro con diferentes

concentraciones de zinc.

\begin{tabular}{lcccc}
\cline { 2 - 4 } & Control & Zn1 & Zn2 & Zn3 \\
\hline $\mathrm{N}^{\circ}$ Ovocitos & 313 & 339 & 309 & 304 \\
$\%$ de Clivados & $66,63^{\mathrm{a}}$ & $71,46^{\mathrm{a}}$ & $75,30^{\mathrm{a}}$ & $73,08^{\mathrm{a}}$ \\
$\%$ Blastocistos/ovocitos & $17,99^{\mathrm{a}}$ & $21,28^{\mathrm{a}}$ & $30,48^{\mathrm{b}}$ & $31,37^{\mathrm{b}}$ \\
$\%$ Blastocistos/clivados & $27,07^{\mathrm{a}}$ & $28,99^{\mathrm{a}}$ & $40,60^{\mathrm{b}}$ & $42,97^{\mathrm{b}}$ \\
\hline
\end{tabular}

Los valores con distintos superíndices dentro de cada fila difieren en $p<0,05$. Los COC bovinos se incubaron en medio de MIV sin suplementar (Control= 0,3 $\mu \mathrm{g} / \mathrm{ml}$ ) o suplementados con Zn (Zn1= 0,7 $\mu \mathrm{g} / \mathrm{ml} ; \mathrm{Zn2}=1,1 \mu \mathrm{g} / \mathrm{ml}$ y Zn3= 1,5 $\mu \mathrm{g} / \mathrm{ml})$.

Los valores se expresan como porcentaje. La tasa de clivaje se evaluó a las 48 horas luego de la inseminación. La tasa de blastocistos incluye aquellos embriones que alcanzaron este estadio luego de 8 días de cultivo.

Se utilizaron 1265 COC en seis repeticiones en diferente días.

Figura 32. Efecto de diferentes concentraciones de zinc en el medio de MIV sobre el porcentaje de blastocistos eclocionados (hatched) a Día 8.

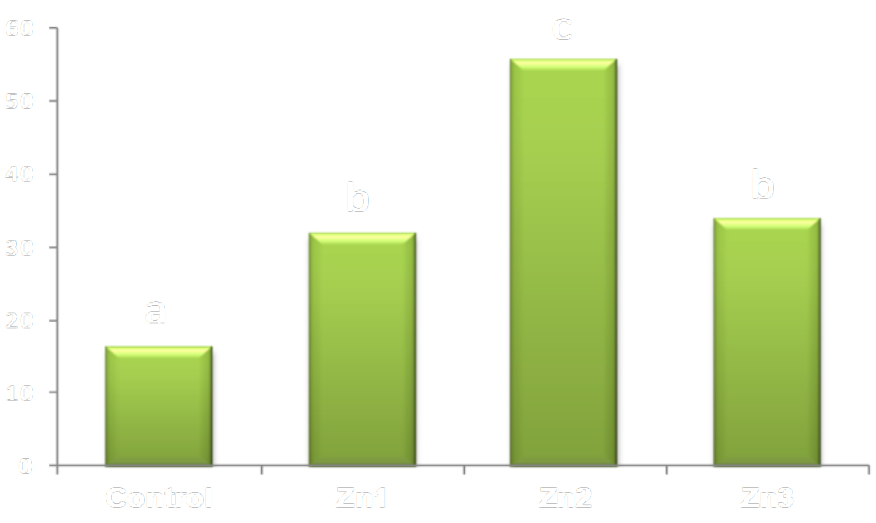

( $a, b$ y $c$ ) indican diferencias estadísticamente significativas $(p<0,05)$. Los COC bovinos se incubaron en medio de MIV sin suplementar (Control= 0,3 $\mu \mathrm{g} / \mathrm{ml}$ ) o suplementados con Zn $(\mathrm{Zn} 1=0,7 \mu \mathrm{g} / \mathrm{ml} ; \mathrm{Zn} 2=1,1 \mu \mathrm{g} / \mathrm{ml}$ y Zn3= 1,5 $\mu \mathrm{g} / \mathrm{ml})$.

Los valores se expresan como el porcentaje de blastocistos eclosionados/blastocistos totales por tratamiento (Control= 16,3\%; $\mathrm{Zn} 1=31,7 \%$; Zn2= 55,6 \%; Zn3= 33,8 \%).

Se evaluaron un total de 262 blastocistos en 5 repeticiones. 
Tabla 6. Velocidad de desarrollo de ovocitos bovinos madurados in vitro con diferentes concentraciones de zinc.

\begin{tabular}{lccc} 
& $\begin{array}{c}\text { Blastocistos } \\
\text { Día 6 }\end{array}$ & $\begin{array}{c}\text { Blastocistos } \\
\text { Día 7 }\end{array}$ & $\begin{array}{c}\text { Blastocistos } \\
\text { Día 8 }\end{array}$ \\
\hline Control & $32,79^{\mathrm{a}}$ & $\%$ & $\%$ \\
Zn1 & $30,16^{\mathrm{a}}$ & $52,46^{\mathrm{a}}$ & $14,75^{\mathrm{a}}$ \\
Zn2 & $27,85^{\mathrm{a}}$ & $49,21^{\mathrm{a}}$ & $20,63^{\mathrm{a}}$ \\
Zn3 & $30,43^{\mathrm{a}}$ & $58,23^{\mathrm{ab}}$ & $13,92^{\mathrm{a}}$ \\
\hline
\end{tabular}

Los valores con distintos superíndices dentro de cada fila difieren en $p<0,05$. Los COC bovinos se incubaron en medio de MIV sin suplementar (Control= 0,3 $\mu \mathrm{g} / \mathrm{ml}$ ) o suplementados con Zn $(Z n 1=0,7 \mu \mathrm{g} / \mathrm{ml} ; \mathrm{Zn2}=1,1 \mu \mathrm{g} / \mathrm{ml}$ y Zn3= 1,5 $\mu \mathrm{g} / \mathrm{ml})$.

Los valores se expresan como el porcentaje de blastocistos alcanzado al Día 6, Día 7 y Día 8 de cultivo para cada tratamiento.

Se evaluaron un total de 262 blastocistos en 5 repeticiones.

\subsubsection{Efecto del Zinc sobre el número de células por blastocisto al Día 8}

En el Experimento 8, el número de células por blastocisto fue mayor cuando los ovocitos fueron madurados en Zn2 y Zn3 $(p<0,05)$. Las diferencias entre el grupo Control y Zn1 no fueron estadísticamente significativas (Figura 33). 
Figura 33. Número de células por blastocisto al Día 8 de cultivo.

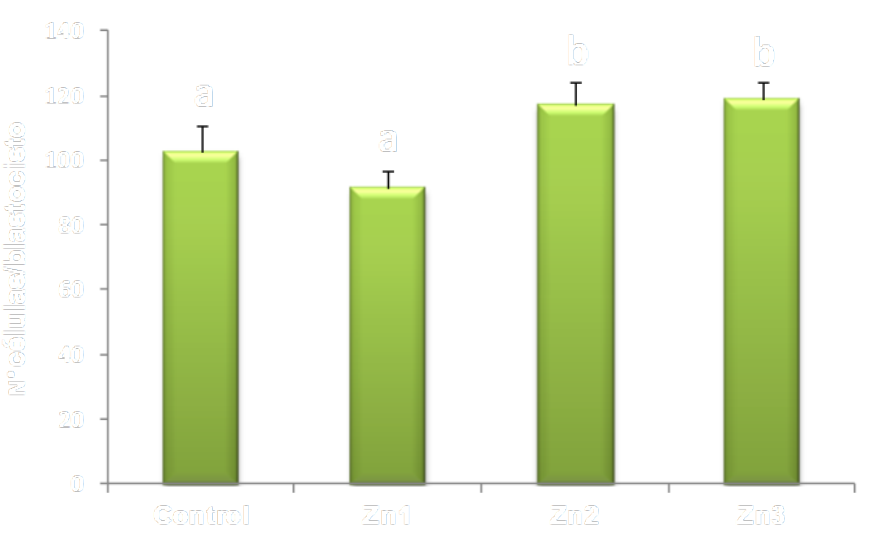

(a y b) indican diferencias estadísticamente significativas $(p<0,05)$.

Los COC bovinos se incubaron en medio de MIV sin suplementar (Control= 0,3 $\mu \mathrm{g} / \mathrm{ml})$ o suplementados con $\mathrm{Zn}(\mathrm{Zn} 1=0,7 \mu \mathrm{g} / \mathrm{ml}$; $\mathrm{Zn} 2=1,1 \mu \mathrm{g} / \mathrm{ml}$ y $\mathrm{Zn} 3=1,5 \mu \mathrm{g} / \mathrm{ml}$ ).

Los valores se expresan como el promedio del número de células/ blastocisto $\pm \mathrm{ESM}$ (Control=102,3 $\pm 8,5 ; \mathrm{Zn} 1=91,2 \pm 5,5 ; \mathrm{Zn} 2=$ $117,4 \pm 6,7 ; \mathrm{Zn3}=119,0 \pm 5,0)$.

Se evaluaron un total de 76 blastocistos en 3 repeticiones.

\subsection{Discusión}

El rol esencial del Zn durante la embriogénesis fue descripto a través de estudios realizados en Xenopus laevis. Estos estudios determinaron la presencia de este mineral en ovocitos y embriones, e identificaron su participación en la acción de las metaloproteínas que intervienen en el desarrollo y la formación de órganos. La deficiencia de Zn se traduce en el desarrollo de embriones sin órganos dorsales incluyendo cerebro, ojos, y espina dorsal en los vertebrados en general (Falchuk y Montorzi, 2001). Además, este microelemento regula la maquinaria de expresión de genes, afecta la estructura de la cromatina, el funcionamiento del ADN, la actividad de numerosos factores de transcripción y la acción de la ARN polimerasa (Falchuk, 1998; Prasad, 2003; Cathomen y Joung, 2008). Estudios recientes sugieren que el Zn 
también podría actuar como un segundo mensajero capaz de traducir señales extracelulares en eventos de señalización intracelular (Yamasaki y col., 2007).

Si bien, la importancia del Zn en la fisiología de las células germinales masculinas ha sido bien establecida, y los efectos del exceso o la deficiencia de este mineral ha sido estudiada en ovocitos de anfibios (Wallace y Misulovin, 1980; Nomizu y col., 1993; Falchuk y col., 1995; Bruinsma y col., 2002; Sun y col., 2007); pocos estudios hasta la fecha han examinado en detalle el rol que desempeña el Zn en los ovocitos de mamífero (Bernhardt y col., 2011). Recientemente se han realizado una serie de trabajos con el objeto de caracterizar el comportamiento y la función del Zn durante la maduración de ovocitos de ratón (Kim y col., 2010; 2011; Bernhardt y col., 2011). Estos autores han demostrado que el contenido total de Zn del ovocito durante su maduración se encuentra sometido a grandes cambios en su concentración, aumentando en más del 50 \% durante la reanudación meiótica y disminuyendo en la etapa embrionaria de dos células. Además, estos cambios profundos en el contenido intracelular de Zn son necesarios para la correcta maduración citoplasmática y la normal progresión de la meiosis (Kim y col., 2011). Kim y sus colaboradores (2011) observaron que los ovocitos de ratón madurados en condiciones extremadamente bajas de $\mathrm{Zn}$ (inferior a $80 \mathrm{ng} / \mathrm{ml}$ de $\mathrm{Zn}$ ) sufren una primera división meiótica acelerada, la detención en telofase I, fallas para alcanzar la meiosis II, y la alteración de la maduración citoplasmática evidenciada por ausencia de desarrollo embrionario temprano. Estos resultados ponen de manifiesto la imprescindible participación del Zn en la obtención de un ovocito de mamífero maduro y competente capaz de sostener el desarrollo embrionario temprano. Sin embargo, otros estudios mencionan que la suplementación con Zn en medios químicamente definidos para la producción de embriones in vitro (MIV/FIV/CIV) en bovinos afecta el desarrollo embrionario temprano resultando en una disminución marcada de la tasa de blastocistos (Stephenson y Bracket, 1999). Estos autores 
encontraron que la adición de $10 \mu \mathrm{g} / \mathrm{ml}$ de $\mathrm{Zn}$ al medio de MIV inhibe la fertíizadìo obstante, la concentración que utilizaron es muy superior a la encontrada normalmente en el plasma bovino (Kincaid, 1999). Kincaid (1999) estableció que valores de 3 a $15 \mu \mathrm{g} / \mathrm{ml}$ en el plasma resultan tóxicos. Esto podría explicar las bajas tasas de desarrollo obtenidas por Stephenson y Bracket (1999). A diferencia de lo descripto previamente, en el presente trabajo de tesis todas las concentraciones de zinc $(0,3 ; 0,7 ; 1,1$ y $1,5 \mu \mathrm{g} / \mathrm{ml}$ de $\mathrm{Zn})$ utilizadas se encuentran por encima de la concentración mínima necesaria $(0,005 \mu \mathrm{g} / \mathrm{ml}$ de Zn) para la maduración del ovocito de ratón (Kim y col., 2010) y por debajo de las concentraciones tóxicas definidas por Kinacid (1999). Las concentraciones de Zn utilizadas en este estudio corresponden a los valores plasmáticos definidos por Kincaid (1999) como deficientes, como en el Control (0,3 $\mu \mathrm{g} / \mathrm{ml} \mathrm{Zn})$ y Zn1 $(0,7 \mu \mathrm{g} / \mathrm{ml} \mathrm{Zn})$ y; adecuados como Zn2 (1,1 $\mu \mathrm{g} / \mathrm{ml} \mathrm{Zn})$ y Zn3 (1.5 $\mu \mathrm{g} / \mathrm{ml} \mathrm{Zn}$ ). Además, para el desarrollo del presente trabajo se utilizó suero fetal bovino durante la MIV, a diferencia del polivinil alcohol utilizado por Stephenson y Bracket (1999) en un medio químicamente definido. La albúmina, presente en el suero, se une al Zn tanto in vivo como in vitro y su ausencia podría alterar la biodisponibilidad de Zn en el medio ambiente que rodea al ovocito y a las células del cúmulus provocando alteraciones en la maduración.

El Zn interviene en la formación de varias enzimas, algunas de las cuales se encuentran involucradas en la síntesis de ADN, en la formación de factores de transcripción y formando parte de moléculas que intervienen en una gran variedad de funciones biológicas (Vallee y Falchuk, 1993; Bernhardt y col., 2011). Inclusive, Falchuk y Montorzi (2001) describieron en Xenopus leavis la existencia de factores de transcripción dependientes de Zn relacionados directamente con el desarrollo embrionario. Además, por su estrecha relación con el ADN, el Zn podría actuar como un regulador de la división celular y de la morfogénesis durante el desarrollo temprano (Riggio y col., 2003). El Zn no solo posee un efecto directo sobre la maduración de la 
célula germinal, sino que también, como se vio en el capítulo anterior, disminuye el daño en el ADN y la tasa de apoptosis de las células del cúmulus que rodean al ovocito. Seino y colaboradores (2002) demostraron que el aumento del daño en la molécula de ADN de las células del cúmulus durante la maduración del ovocito humano, reduce la tasa de fertilización y la calidad de los blastocistos obtenidos (blastómeros asimétricos y con mayor fragmentación).

Estudios previos indican que un alto número de células del cúmulus apoptóticas se relaciona con una menor capacidad de desarrollo del ovocito (Høst y col., 2002; Ikeda y col., 2003; Corn y col., 2005). La alteración de la célula germinal, producto de un elevado número de células del cúmulus con apoptosis, se ha visto reflejada en menores tasas de fertilización (Høst y col., 2002) y de blastocistos (Corn y col., 2005). Esto podría deberse a la particular comunicación que existe entre las células del cúmulus y el ovocito (Corn y col., 2005). Las células del cúmulus se hallan unidas metabólicamente al oolema de la célula germinal a través de uniones nexo (gap) (Anderson y Albertini, 1976; Heikinheimo y Gibbons, 1998). Estas uniones gap permiten la comunicación bilateral entre el cúmulus y el ovocito permitiendo el correcto funcionamiento de ambos tipos celulares. Como resultado de esta dependencia mutua, es muy probable que cualquier proceso o molécula relacionada con el fenómeno de apoptosis en las células del cúmulus tenga un impacto similar en el ovocito, disminuyendo su calidad y su capacidad de desarrollo posterior (Ikeda y col., 2003).

Todo lo expuesto anteriormente contribuye a reafirmar los resultados obtenidos en el presente estudio que indicaron que, el aporte adecuado de Zn durante la maduración del ovocito aumentó la tasa de blastocistos, no hubo retrasos en la velocidad de desarrollo hasta el estadio de blastocisto (Días 6, 7 y 8), el porcentaje de blastocistos eclosionados (hatching) fue mayor y que la calidad de los mismos (evaluado a través del número de blastómeras) fue mejor con un aporte de $\mathrm{Zn}$ adecuado. Estos parámetros del desarrollo preimplantacional, fueron 
también observados en embriones de ratón producidos in vitro a partir de ovocitos madurados y fertilizados in vivo, donde las hembras donantes de los cigotos fueron alimentadas con una dieta con aporte de $\mathrm{Zn}$ adecuado (Peters y col., 1991). Las hembras alimentadas con una dieta deficiente, produjeron cigotos que desarrollaron con mayor dificultad hasta el estadio de blastocisto y requirieron de mayor tiempo para alcanzar este estadio. Además, los embriones obtenidos a partir del cultivo in vitro de cigotos recuperados de hembras deficientes presentaron un número menor de células por blastocisto (Peters y col., 1991).

En conclusión, los resultados de este estudio muestran que: 1) el agregado de Zn al medio de MIV no modificó la tasa de clivaje con respecto al Control; 2) el agregado de Zn al medio de MIV en concentraciones similares a las concentraciones plasmáticas normales (1,1 y 1,5 $\mu \mathrm{g} / \mathrm{ml}$ de Zn) aumentó la tasa de blastocistos; 3) la suplementación con Zn (0,7; 1,1 y 1,5 $\mu \mathrm{g} / \mathrm{ml}$ de Zn) aumentó la tasa de blastocistos eclosionados (hatched), presentándose en mayor proporción en los madurados con 1,1 $\mathrm{gg} / \mathrm{ml}$ de $\mathrm{Zn}$; 4) la velocidad de desarrollo fue mayor cuando los COC fueron madurados en presencia de 1,5 $\mu \mathrm{g} / \mathrm{ml}$ de $\mathrm{Zn} ; 5)$ los ovocitos madurados en concentraciones de $\mathrm{Zn}$ similares a las concentraciones plasmáticas normales (1,1 y 1,5 $\mu \mathrm{g} / \mathrm{ml}$ de $\mathrm{Zn}$ ) desarrollaron en blastocistos con mayor número de células; 6) nuestros resultados sugieren que el aporte de $\mathrm{Zn}$ en concentraciones similares a las concentraciones plasmáticas "normales" durante la maduración del ovocito bovino resulta indispensable para el desarrollo embrionario preimplantacional. 
Capitulo 4 


\section{Rol de las células del cúmulus como puente metabólico entre el medio externo y el ovocito, con diferentes niveles en el aporte de Zn durante la MIV.}

\subsection{Introducción}

Los ovocitos de mamíferos crecen y se desarrollan en intima relación con las células somáticas adyacentes. Durante la formación del antro folicular (en la foliculogénesis) las células de la granulosa se diferencian en dos linajes celulares funcional y anatómicamente diferentes: las células de la granulosa mural que recubren la pared del folículo, y las células del cúmulus, que forman una asociación íntima con el ovocito (Huang y Wells, 2010).

Durante la MIV, los ovocitos de mamíferos se encuentran rodeados por las células del cúmulus a las que se hayan unidos metabólicamente (Moor y col., 1980). Las CC poseen proyecciones citoplasmáticas transzonales (PTZ) altamente especializadas que penetran la zona pelúcida y se comunican con el citoplasma del ovocito a través de uniones nexo (uniones gap) (Albertini y col., 2001). Las uniones gap ubicadas en los extremos de estas PTZ (y entre las células del cúmulus) conectan a las CC entre sí y con el ovocito, facilitando la transferencia de moléculas de bajo peso molecular como iones, metabolitos y aminoácidos necesarios para el 
crecimiento de la gameta, así como también pequeñas moléculas reguladoras como el AMPc (Larsen y Wert, 1988; Larsen, 1989; Albertini y col., 2001; Sutton y col., 2003; Gilchrist y col., 2008).

Por otra parte, Kim y colaboradores (1996) demostraron que si bien, la presencia de CC junto a ovocitos bovinos no era necesario para la maduración nuclear, ellas desempeñan un papel importante en la capacidad de los mismos para desarrollarse hasta la etapa de blastocisto. Es por ello que en la actualidad, la morfología del cúmulus es uno de los criterios más utilizados en la selección de los COC para la MIV. Características tales como, mayor número de capas de células y mayor grado de compactación, están directamente relacionados con mejores resultados en el desarrollo, comparados con ovocitos rodeados de un cúmulus comprometido u ovocitos desnudos (DO) (Shioya y col., 1988; Madison y col., 1992; Lonergan y col., 1994; Goud y col., 1998). Se ha comprobado además, la existencia de una relación positiva entre el número de $\mathrm{CC}$ en el cocultivo y la capacidad de desarrollo posterior de los ovocitos (Hashimoto y col., 1998).

Debido a la delicada relación existente entre el carácter esencial del Zn y su toxicidad, su homeostasis es vital para el óptimo funcionamiento de cualquier organismo. Durante las últimas dos décadas, varios de los mecanismos de ingreso del Zn a la célula han sido identificados. La captación celular de Zn se realiza por múltiples mecanismos, entre los que se encuentran: cotransporte unido a aminoácidos (cisteína o histidina), unión al receptor de la transferrina, unión al transportador de metales divalente (DMT1), y por unión a las proteínas transportadoras específicas para Zn llamadas ZIP (Gunshin y col., 1997; Paulsen y Saier, 1997; Tapiero y Tew, 2003; Eide, 2006). Si bien, el conocimiento sobre la existencia de estos transportadores en el COC es todavía muy limitado, Ménézo y colaboradores (2011) han publicado recientemente la expresión de transportadores ZIP en COC humanos. 
En consecuencia, se diseñaron una serie de experimentos con el fin estudiar el rol de las $\mathrm{CC}$ en el transporte de $\mathrm{Zn}$ entre el medio externo y el ovocito.

\subsection{Material y métodos}

\subsubsection{Complejos Ovocitos-Cúmulus (COC)}

Los ovarios de bovino obtenidos de frigorífico fueron transportados al laboratorio en solución fisiológica a $37^{\circ} \mathrm{C}$ dentro de las 3 hs de realizada la extracción. Los ovarios fueron recolectados independientemente de la etapa del ciclo estral de las hembras y los COC fueron aspirados y seleccionados como se describe en 2.3. Las repeticiones de cada experimento ( $n=$ 4) se realizaron en días diferentes y en cada día se obtuvieron 300 COC, utilizando 50 COC por tratamiento.

\subsubsection{Maduración in vitro (MIV)}

Los DO se obtuvieron a partir de ovocitos con el cúmulus completo, que por pipeteo fueron separados de las células que los rodean. Luego los DO se lavaron en medio TCM-199 con 15 mM de Hepes y $10 \%$ (v/v) de SFB y dos veces en el medio de MIV. Grupos de 10 COC o de 10 DO fueron transferidos a microgotas de $50 \mu \mathrm{l}$ de medio MIV bajo aceite mineral (Squibb, Princeton, $\mathrm{NJ}$ ) equilibrado previamente en una incubadora de $\mathrm{CO}_{2}$. Los $\mathrm{COC}$ y los DO fueron cultivados a $39{ }^{\circ} \mathrm{C}$ en $5 \%$ de $\mathrm{CO}_{2}$ y humedad a saturación por 24 hs.

\subsubsection{Cocultivo de CC}

Las monocapas de CC fueron preparadas a partir de COC obtenidos por aspiración folicular como se describió anteriormente (2.3). Los ovocitos se separaron de las CC en medio 
de MIV con pipeta de punta fina. Luego, los ovocitos fueron descartados y las células se pipetearon vigorosamente para permitir su separación. De la suspensión de CC se tomó una muestra, se determinó la concentración con una cámara hemocitométrica y se diluyó en medio de MIV hasta obtener una concentración final de 1 × $10^{6} \mathrm{CC} / \mathrm{ml}$. Para cada cocultivo se sembró 0,5 $\mathrm{ml}$ de esta suspensión de CC bajo aceite mineral. El medio de cultivo se renovó cada 48 horas hasta lograr el $70-80 \%$ de confluencia, que se obtuvo dentro de los 4 - 5 días posteriores al inicio del cocultivo. El porcentaje de células vivas, establecido con un colorante vital, fue mayor al $80 \%$ al comienzo del cultivo.

\subsubsection{Fertilización in vitro (FIV) y Cultivo in vitro (CIV)}

Los medios y el procedimiento utilizados para la FIV y la CIV corresponden a los descriptos previamente en 2.4 y 2.5 respectivamente.

\subsubsection{Número de células por blastocisto a Día 8}

Los blastocistos de Día 8 se fijaron en formaldeído al 4 \% luego de haber sido lavados 3 veces en PBS con $1 \%$ de PVP. Los embriones se incubaron con Triton X-100 al $1 \%$, se colorearon con Hoecht 33342 (2.6) y se montaron con glicerol entre portaobjeto y cubreobjeto. El número total de células de los blastocistos (a Día 8, Grado 1) se determinó contando el número de núcleos con un microscopio de epifluorescencia a 40 X y con filtro de exitación de 365 nm, filtro de barrido de 400 nm y un filtro de emisión de 400 nm.

\subsubsection{Análisis estadístico}

Se utilizó un diseño experimental completamente aleatorio en bloque con un arreglo $2 \times 3$ factorial. El análisis estadístico de las variables binomiales (tasa de clivaje y tasa de 
blastocistos) se realizó mediante una regresión logística con el procedimiento GENMOD de SAS 9.0 (SAS Inst. Inc.). Se utilizó una distribución Binomial y un enlace Logit. El modelo logístico incluyó los efectos del bloque $(n=6)$, del Zn (Control vs. Zn3), de la forma de maduración (COC vs. DO + CC vs. DO) y la interacción (Zn por forma de maduración). El conteo de células por embrión se analizó mediante una regresión Poisson con el procedimiento GENMOD de SAS 9.0 (SAS Inst. Inc.). Se utilizó una distribución Poisson y un enlace Log. El modelo de regresión Poisson incluyó los efectos descriptos anteriormente. Las variables continuas se expresan como el promedio \pm ESM. Las variables binomiales están expresadas como porcentaje. Se consideraron efectos significativos a las $p<0,05$ y tendencias a las $p<$ 0,10 y $p>0,05$. En el caso de la interacción se consideró significativa a la $p<0,10$.

\subsection{Diseño experimental}

\subsubsection{Rol de las CC durante la MIV de ovocitos bovinos en presencia de Zn sobre la capacidad de desarrollo posterior}

En el Experimento 9, los ovocitos se maduraron in vitro en tres formas diferentes: complejos ovocito-cúmulus (400 COC), cocultivo de ovocitos desnudos junto a monocapas de CC (400 DO + CC) y ovocitos desnudos (400 DO). En cada forma de maduración, los ovocitos se dividieron en 2 grupos correspondientes a los tratamientos sin suplementación de Zn (Control= 0,3 $\mu \mathrm{g} / \mathrm{ml})$ y con $\mathrm{Zn}(\mathrm{Zn3}=1,5 \mu \mathrm{g} / \mathrm{ml})$. Los ovocitos fueron colectados en cuatroíals

diferentes ( $n=4$ repeticiones) y en cada repetición se dividieron en los siguientes grupos: 50 COC; 50 COC Zn; 50 DO + CC; 50 DO + CC Zn; 50 DO y 50 DO Zn. Luego de la MIV, los ovocitos fueron fertilizados in vitro y cultivados hasta el estadio de blastocisto como se describe en 2.4 y 2.5 respectivamente. La tasa de clivaje se evaluó 48 horas luego de la FIV. La tasa de 
desarrollo hasta blastocisto se evaluó el Día 8 del cultivo e incluyó a los embriones que alcanzaron los estadios de blastocisto expandido y eclosionado.

6.3.2 Rol de las CC durante la MIV de ovocitos bovinos en presencia de Zn sobre el número de células por blastocisto al Día 8

En el Experimento 10, se analizó el efecto de las CC durante la MIV, en presencia de Zn, sobre el número promedio de células por blastocisto al Día 8 de cultivo. El número de células se evaluó sobre un total de 72 embriones, 12 embriones por tratamiento (3 repeticiones) obtenidos en el Experimento 9.

\subsection{Resultados}

\subsubsection{Rol de las CC durante la MIV de ovocitos bovinos en presencia de Zn sobre la capacidad de desarrollo posterior}

En el Experimento 9, no se observó interacción entre la forma de maduración (COC, DO + CC y DO) y la disponibilidad de Zn (Control y Zn3). La tasa de clivaje fue mayor cuando los ovocitos fueron madurados con el cúmulus completo (COC) (Control= 76,65 \% y Zn3= 82,41\%; $p<0,05)$, los ovocitos desnudos en cocultivo con CC alcanzaron una tasa menor de clivaje comparado con los COC (Control= 70,09 \% y Zn3=73,78\%; $p<0,05$ ) mientras que, el porcentaje más bajo de clivaje se obtuvo a partir de ovocitos desnudos (DO) (Control= 59,90\% y Zn3= 54,56 \%; $p<0,05)$ (Figura 34 A). El agregado de $Z n$ al medio de maduración no tuvo ningún efecto sobre la tasa de clivaje de ovocitos madurados en presencia o ausencia de células del cúmulus (COC, DO + CC y DO) (Figura 34 C). Los COC alcanzaron el porcentaje más alto de desarrollo hasta el estadio de blastocisto (Control= 25,07 \% y Zn3=40,46 \%; $p<$ 
0,01), los ovocitos desnudos en cocultivo con CC alcanzaron una tasa menor de blastocistos comparado con los madurados con cúmulus completo (Control= 22,11\% y Zn3=26,21\%; $p<$ $0,01)$ mientras que, el porcentaje más bajo de blastocistos se obtuvo a partir de ovocitos desnudos (DO) (Control= 8,56 \% y Zn3= 12,57 \%; $p<0,01$ ) (Figura 34 B). Además, el agregado de $\mathrm{Zn}$ al medio de MIV aumentó significativamente la tasa de blastocistos obtenidos en presencia o ausencia del cúmulus $(p<0,01)$ (Figura 34 D).

\subsubsection{Rol de las CC durante la MIV de ovocitos bovinos en presencia de Zn sobre el número de células por blastocisto al Día 8}

En el Experimento 10, se observó interacción entre la forma de maduración (COC, DO + CC y DO) y la disponibilidad de Zn (Control y Zn3; $p<0,0001$ ). El número de células por blastocisto fue mayor con el agregado de $\mathrm{Zn}$ al medio de MIV únicamente cuando se maduraron COC intactos u ovocitos desnudos en cocultivo $(C O C=110,5 \pm 4,35$; COC Zn3= 129,1 $\pm 4,77$; $D O+C C=107 \pm 4,99 ; D O+C C$ Zn3= 118,2 $\pm 5,66 ; D O=91,42 \pm 4,54 ; D O ~ Z n 3=93,3 \pm 6,68 ; p<$ 0,001). Los ovocitos madurados con sus cúmulus intactos (COC) y en presencia de $1,5 \mu \mathrm{g} / \mathrm{ml}$ Zn (Zn3) presentaron el número de células por blastocisto más elevado $(p<0,001)$ (Figura 35). 
FIGURA 34. Efecto de la presencia o ausencia del cúmulus oophorus sobre el desarrollo posterior hasta el estadio de blastocisto de ovocitos bovinos madurados in vitro con y sin zinc.
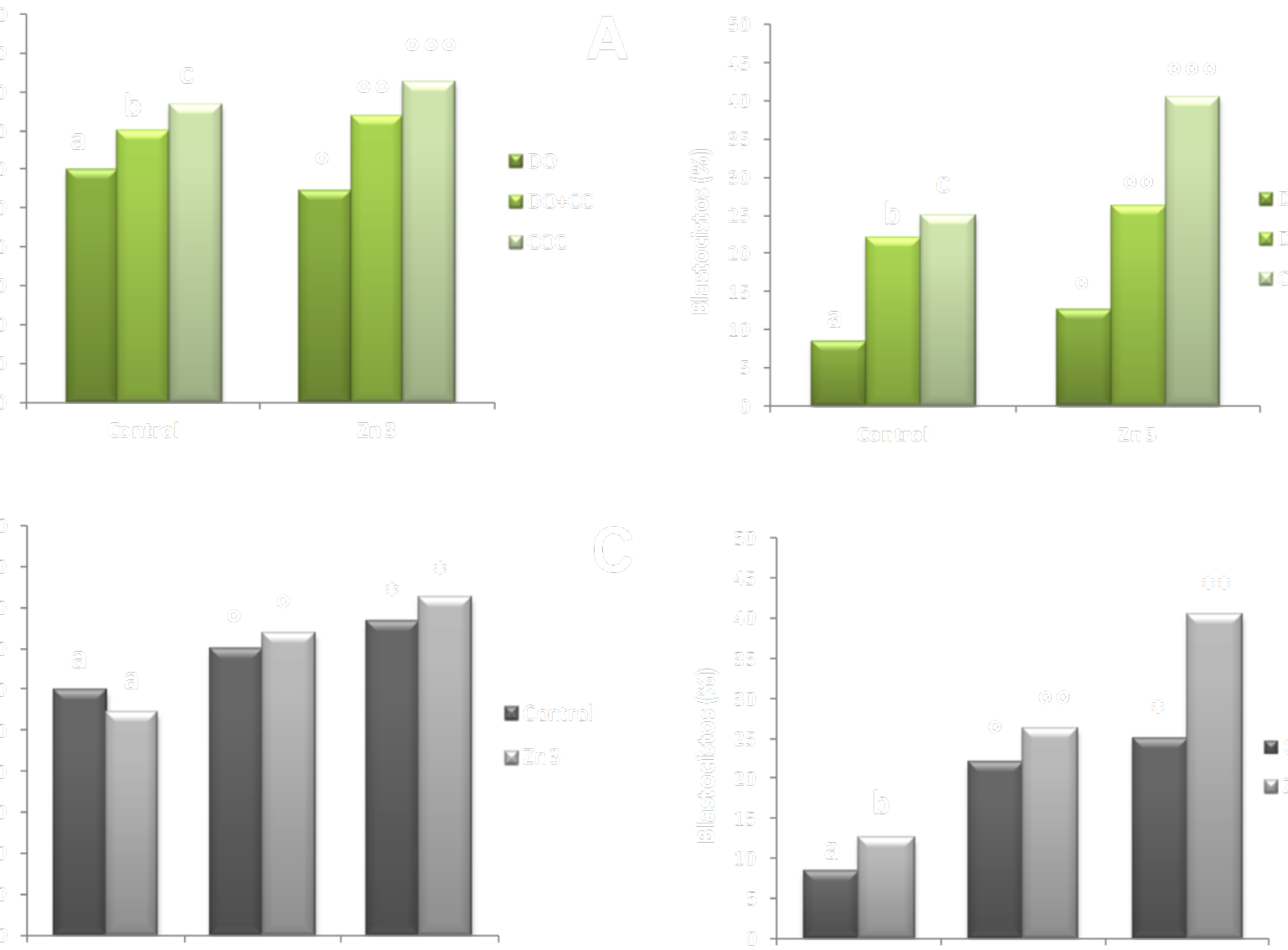

$\mathbf{C O C}=$ complejo ovocito cúmulus; $\mathbf{D O}+\mathbf{C C}=$ ovocitos desnudos + monocapa de CC; $\mathbf{D O}=$ ovocitos desnudos. Control: sin agregado de Zn; Zn3: $1,5 \mu \mathrm{g} / \mathrm{ml} \mathrm{Zn}$.

$\left(a, b\right.$ y c), $\left({ }^{\circ},{ }^{\circ 0} y^{\circ 00}\right)$ y $\left({ }^{*},{ }^{* *} y^{* * *}\right)$ indican diferencias significativas $(p<0,05)$. Efecto de la presencia o ausencia de las células del cúmulus sobre la tasa de clivaje (A) y la tasa de blastocisto (B). Efecto del agregado de Zn durante la MIV sobre la tasa de clivaje (C) y la tasa de blastocisto (D).

Se maduraron un total de 1200 ovocitos repartidos en 4 repeticiones. En cada repetición se maduraron $100 \mathrm{COC}$ (Control=50 COC y Zn3= $50 \mathrm{COC}$ ); $100 \mathrm{DO}$ (Control= $50 \mathrm{DO}$ y Zn3= 50 DO) y $100 \mathrm{DO}$ para cocultivo (Control= $50 \mathrm{DO}+\mathrm{CC}$ y Zn3= $50 \mathrm{DO}+\mathrm{CC}$ ). 
Figura 35. Promedio de células por blastocisto al día 8 de cultivo desarrollados a partir de ovocitos madurados en presencia o ausencia de células del cúmulus con o sin zinc.

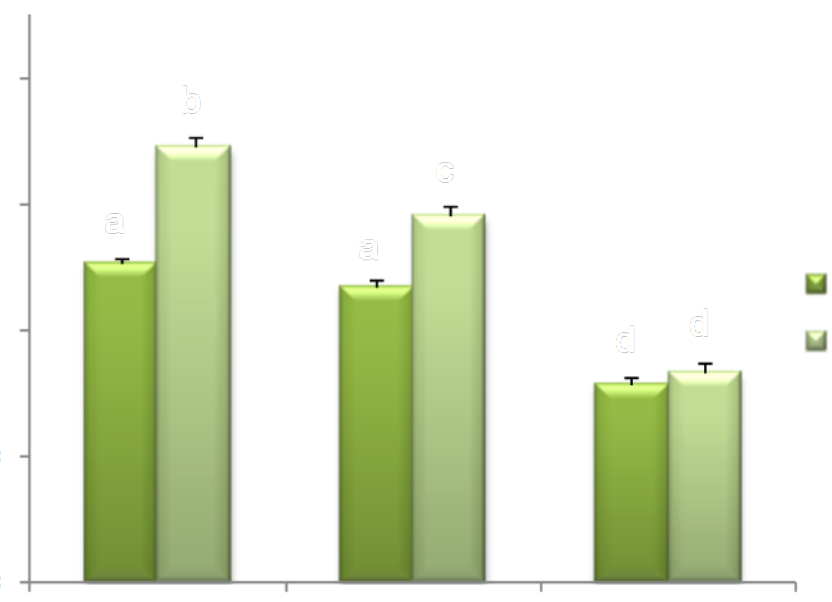

$\mathbf{C O C}=$ complejo ovocito cúmulus; $\mathbf{D O}+\mathbf{C C}=$ ovocitos desnudos + monocapa de CC; $\mathbf{D O}=$ ovocitos desnudos. Control: sin agregado de Zn; Zn3: $1,5 \mu \mathrm{g} / \mathrm{ml} Z \mathrm{Zn}$. (a, b, c y d) indican diferencias significativas $(p<0,001)$. Valores expresados como el promedio \pm ESM. Se evaluaron un total de 72 blastocistos, para cada grupo se evaluaron 12 blastocistos Grado 1 obtenidos en el Experimento 9.

\subsection{Discusión}

Dentro del folículo, el ovocito se encuentra rodeado por células de la granulosa que durante el proceso de foliculogénesis se diferencian en células murales y CC (Edson y col., 2009). Estas células se encuentran íntimamente relacionadas con el ovocito y están encargadas de proporcionarle nutrientes, factores involucrados en la maduración y un microambiente adecuado que asegure la adquisición de la capacidad de desarrollo posterior (Eppig, 1991; Pangas y Matzuk, 2005; Gilchrist y col., 2008). Las CC, poseen uniones gap ubicadas en los extremos de los PTZ que las conectan al ovocito creando de esta manera un soporte metabólico del mismo, transportando moléculas de bajo peso molecular, iones y aminoácidos (Larsen y Wert, 1988; Larsen, 1989; Tanghe y col., 2002). Además, estas uniones participan en 
la regulación meiótica de los ovocitos al permitir el paso de pequeñas moléculas reguladoras, tales como AMPc y purinas (Dekel y Beers, 1980; Salustri y Siracusa, 1983; Eppig y Downs, 1984; Racowsky, 1985; Racowsky y Satterlie, 1985).

La interrupción prematura de esta comunicación altera la capacidad de desarrollo posterior del ovocito (Modina y col., 2001). La inhibición de las uniones gap afecta considerablemente la maduración citoplasmática de los ovocitos bovinos y por lo tanto, la tasa de blastocistos obtenidos in vitro (Ali y col., 2005). Esto es debido, probablemente, a la falta de transferencia de señales moleculares específicas que coordinan la maduración final de los mismos (Gilchrist y col., 2004, Lodde y col., 2007).

La tasa de blastocistos aumentó cuando la MIV se realizó en presencia de CC, alcanzando la tasa más alta aquellos ovocitos madurados con su cúmulus intacto (COC). Esto concuerda con lo descrito por diversos autores, quienes observaron que la eliminación de las CC antes de la MIV deteriora la maduración de los ovocitos en diferentes especies (Eppig, 1991; Grazul-Bilska y col., 1997; Vozzi y col., 2001; Tanghe y col., 2002; Gilchrist y col., 2004; Assidi y col., 2008) y que el cocultivo de los ovocitos desnudos, con complejos ovocito-cúmulus o con $\mathrm{CC}$, restaura parcialmente el potencial de desarrollo de los ovocitos sin cúmulus (de Matos y col., 1997; Mori y col., 2000; Fatehi y col., 2002; Matzuk y col., 2002; Tanghe y col., 2002; Wongsrikeao y col., 2005). Esta mejoría podría explicarse por el tipo de comunicación que existe entre las CC y el ovocito, la cual implica además de las uniones gap, la participación de diversos factores parácrinos de señalización (Gilchrist y col., 2004). La acción mejoradora de la presencia de estas células en ovocitos desnudos de bovino y de ratón se pone en evidencia a través de la producción de factores difusibles durante la maduración (Luciano y col., 2005; Ge y col., 2008). Por otro lado, en nuestro estudio se pone de manifiesto que el agregado de $\mathrm{Zn}$ durante la MIV mejora la calidad embrionaria, evidenciada por el aumento del número de 
células por blastocisto, sólo cuando las CC se encuentran presentes. Estos resultados evidencian la participación de las CC en el efecto beneficioso del Zn sobre la calidad embrionaria.

El $\mathrm{Zn}$ es absorbido desde la luz intestinal en su estado divalente $\left(\mathrm{Zn}^{++}\right)$(Tapiero y Tew, 2003; Mafra y Cozzolino, 2004). Dentro del plasma, el $\mathrm{Zn}^{++}$se une principalmente a albúmina y a $\alpha_{2}$-macroglubulina, quedando una pequeña fracción en forma libre (Tapiero y Tew, 2003). La captación celular de Zn se realiza por múltiples mecanismos, entre los que se encuentran: cotransporte unido a aminoácidos (cisteína o histidina), unión al receptor de la transferrina, unión al transportador DMT1, y por unión a las proteínas transportadoras ZIP (Gunshin y col., 1997; Paulsen y Saier, 1997; Tapiero y Tew, 2003; Eide, 2006). Los transportadores ZIP se encuentran presentes en una amplia variedad de tejidos y tipos celulares (Cousins y col., 2006). En humanos, existen 14 tipos de ZIP y todos ellos aumentan la concentración del Zn intracitoplasmático al mediar el flujo de entrada del Zn hacia la célula, o al liberar el Zn de las vesículas intracelulares hacía el citoplasma (Cousins y col., 2006). Si bien, se desconoce la contribución relativa de cada uno de los transportadores anteriormente mencionados, se cree que la concentración tisular óptima de Zn es mantenida principalmente por acción de las ZIP (Eide, 2004, 2006; Cousins y col., 2003, 2006; Jackson y col., 2008; Lichten y Cousins, 2009).

El agregado de Zn durante la MIV aumentó la producción de blastocistos posterior, independientemente de la presencia de CC, lo que indicaría la importancia de este mineral en el metabolismo del ovocito. El conocimiento acerca del mecanismo por el cual el Zn ingresa al COC es aun limitado, al igual que la información sobre los transportadores de este metal presentes en ovocitos y CC. Ménézo y colaboradores (2011) determinaron la expresión de los transportadores ZIP en el COC humano encontrando ZIP14 y ZIP8 en CC mientras que en ovocitos observaron la expresión más marcada de ZIP14. El efecto beneficioso del Zn durante 
la MIV sobre el desarrollo embrionario posterior, tanto en presencia como en ausencia de las $\mathrm{CC}$, sugiere la existencia de transportadores de $\mathrm{Zn}$ en el ovocito bovino. Considerando el trabajo de Ménézo y colaboradores (2011), la proteína ZIP14 podría ser uno de los transportadores involucrados en el ingreso de $\mathrm{Zn}$ al ovocito bovino.

En consecuencia, los resultados del presente estudio muestran que: 1) el agregado de Zn durante la MIV mejoró la tasa de blastocistos; 2) la producción de blastocistos fue mayor cuando los ovocitos se maduraron en presencia de células del cúmulus; 3) la tasa de blastocistos más alta se obtuvo a partir de los ovocitos madurados con el cúmulus intacto (COC); 4) el agregado de Zn durante la MIV mejoró la calidad de los embriones obtenidos cuando las células del cúmulus se encontraron presentes; 5) los complejos ovocito-cúmulus madurados con Zn3 produjeron la mejor tasa de blastocistos y la mejor calidad de los mismos. La presencia de Zn en el medio de MIV mejoró la calidad de los embriones cuando los ovocitos se maduraron con el cúmulus intacto o en presencia de una monocapa de células del cúmulus. Esto sugiere que el efecto beneficioso del Zn durante la maduración del ovocito dependería en parte de la comunicación entre las células del cúmulus y el ovocito. Además, nuestros resultados sugieren que el aumento en la tasa de desarrollo embrionario, independientemente de la presencia de las CC, podría deberse a la existencia de transportadores de Zn en el COC bovino. 
Conclusiones Finales 
Efecto de distintas concentraciones de Zn sobre la maduración de los ovocitos bovinos.

- El agregado de Zn al medio de MIV no modificó el área de expansión del cúmulus luego de la maduración.

- La suplementación con Zn no modificó la concentración intracelular de GSH/GSSG en ovocitos y células del cúmulus excepto cuando se utilizó una concentración de 0,7 $\mu \mathrm{g} / \mathrm{ml}$ Zn.

- La tasa de apoptosis en las células del cúmulus disminuyó conforme aumentó la concentración de Zn en el medio de maduración.

- El porcentaje de células del cúmulus sin daño en el ADN fue menor cuando se cultivaron en presencia de 1,1 y 1,5 $\mathrm{\mu g} / \mathrm{ml}$ de Zn. Igual comportamiento presentó el grado de daño del ADN siendo las células menos afectadas aquellas cultivas en 1,1 y 1,5 $\mu \mathrm{g} / \mathrm{ml}$ de $\mathrm{Zn}$.

- La actividad SOD en los COC aumentó con el agregado de $1,5 \mu \mathrm{g} / \mathrm{ml}$ de $\mathrm{Zn}$ en el medio de MIV.

Efecto de distintas concentraciones de Zn sobre la capacidad de desarrollo posterior hasta el estadio preimplantacional de blastocisto.

- El agregado de Zn al medio de MIV no modificó la tasa de clivaje con respecto al Control.

- El agregado de $\mathrm{Zn}$ al medio de MIV en concentraciones similares a las concentraciones plasmáticas normales (1,1 y 1,5 $\mu \mathrm{g} / \mathrm{ml}$ de Zn) aumentó la tasa de blastocistos.

- La calidad de los embriones (expresada como blastómeras por embrión, velocidad de desarrollo y la tasa de eclosión) fue mejor cuando se agregó Zn al medio de MIV. 
Rol de las células del cúmulus como puente metabólico entre el medio externo y el ovocito, con diferentes niveles en el aporte de Zn durante la MIV

- La tasa de blastocisto aumentó cuando la MIV se realizó en presencia de CC, alcanzando la tasa más alta con aquellos ovocitos madurados con su cúmulus intacto $(\mathrm{COC})$.

- El agregado de Zn al medio de MIV solo mejoró la calidad de los embriones (expresada como blastómeras por embrión) cuando se maduraron ovocitos en presencia de células del cúmulus.

- El agregado de Zn durante la MIV mejoró la tasa de blastocisto independientemente de la presencia de CC.

En consecuencia, todas las evidencias obtenidas sugerirían que el zinc actuaría como un factor importante durante la maduración del ovocito bovino, favoreciendo el desarrollo embrionario temprano. Estas evidencias sugerirían además, la posible existencia de transportadores de zinc en el ovocito bovino. 


\section{Anexos}


Técnica de producción de embriones in vitro

Soluciones Stock para la preparación de medios de cultivo

Stock H (250 mM Hepes)

\begin{tabular}{|lr|}
\hline Hepes ácido & $15,00 \mathrm{~g}$ \\
\hline Hepes sódico & $16,25 \mathrm{~g}$ \\
\hline Rojo fenol & $50 \mathrm{mg}$ \\
\hline Agua destilada & $500 \mathrm{ml}$ \\
\hline $\mathrm{pH}$ & $7,4-7,5$ \\
\hline Osmolaridad & $384 \mathrm{mOsm}$ \\
\hline Esterilizar por filtración $(0,22 \mu \mathrm{m})$ y guardar a $4^{\circ} \mathrm{C}$. Preparar cada 30 días. \\
\hline
\end{tabular}

Stock 2 X TCM-199

Disolver 1 sobre de TCM-199 (Medio de cultivo 199) en $500 \mathrm{ml} \mathrm{de} \mathrm{H}_{2} \mathrm{O}$ destilada para obtener una solución $2 \mathrm{X}$ y agregar:

Sulfato de kanamicina $50 \mathrm{mg}$

Penicilina G $59 \mathrm{mg}$

Estreptomicina $100 \mathrm{mg}$

Rojo fenol $20 \mathrm{mg}$

Esterilizar por filtración $(0,22 \mu \mathrm{m})$ y guardar a $4^{\circ} \mathrm{C}$. Preparar cada semana.

Stock S2

\begin{tabular}{|lr|}
\hline $\mathrm{NaCl}$ & $6,294 \mathrm{~g}$ \\
\hline $\mathrm{KCl}$ & $0,534 \mathrm{~g}$ \\
\hline $\mathrm{KH}_{2} \mathrm{PO}_{4}$ & $0,162 \mathrm{~g}$ \\
\hline Penicilina & $0,060 \mathrm{~g}$ \\
\hline Estreptomicina & $0,050 \mathrm{~g}$ \\
\hline Agua destilada & $100 \mathrm{ml}$ \\
\hline
\end{tabular}


Esterilizar por filtración $(0,22 \mu \mathrm{m})$ y guardar a $4{ }^{\circ} \mathrm{C}$.Preparar cada 3 meses.

Stock TL $10 \mathrm{X}$

\begin{tabular}{|lr|}
\hline $\mathrm{NaCl}$ & $6,662 \mathrm{~g}$ \\
\hline $\mathrm{KCl}$ & $0,238 \mathrm{~g}$ \\
\hline $\mathrm{NaH}_{2} \mathrm{PO}_{4} \cdot 2 \mathrm{H}_{2} \mathrm{O}$ & $0,062 \mathrm{~g}$ \\
\hline Penicilina & $0,060 \mathrm{~g}$ \\
\hline Agua destilada & $100 \mathrm{ml}$ \\
\hline Osmolaridad (Solución $1 \mathrm{X})$ & $235 \mathrm{mOsm}$ \\
\hline Esterilizar por filtración $(0,22 \mu \mathrm{m})$ y guardar a $4{ }^{\circ} \mathrm{C}$. Preparar cada 3 meses. \\
\hline
\end{tabular}

Stock $10 X$

\begin{tabular}{|lr|}
\hline $\mathrm{NaCl}$ & $4,675 \mathrm{~g}$ \\
\hline $\mathrm{KCl}$ & $0,230 \mathrm{~g}$ \\
\hline $\mathrm{NaH}_{2} \mathrm{PO}_{4} \cdot 2 \mathrm{H}_{2} \mathrm{O}$ & $0,045 \mathrm{~g}$ \\
\hline Penicilina & $0,060 \mathrm{~g}$ \\
\hline Hepes ácido & $1,192 \mathrm{~g}$ \\
\hline Hepes sódico & $1,302 \mathrm{~g}$ \\
\hline Lactato de sodio & $3,680 \mathrm{ml}$ \\
\hline Agua destilada & $100 \mathrm{ml}$ \\
\hline pH & 7,3 \\
\hline Esterilizar por filtración $(0,22 \mu \mathrm{m})$ y guardar a $4^{\circ} \mathrm{C}$. Preparar cada 3 meses. \\
\hline
\end{tabular}

Stock de Heparina (10 mg/ml de Heparina)

\begin{tabular}{|lr|}
\hline Heparina (sulfato) & $20 \mathrm{mg}$ \\
\hline Solución salina $(0,9 \%)$ estéril & $2 \mathrm{ml}$ \\
\hline No filtrar y guardar a $4^{\circ} \mathrm{C}$. Preparar cada semana. \\
\hline
\end{tabular}


Stock de Hipotaurina

\begin{tabular}{|lc|}
\hline Hipotaurina & $2,182 \mathrm{~g}$ \\
\hline Agua destilada & $10 \mathrm{ml}$ \\
\hline Esterilizar por filtración $(0,22 \mu \mathrm{m})$ y guardar a $4{ }^{\circ} \mathrm{C}$. Preparar cada semana. \\
\hline
\end{tabular}

SPAD $100 X$

$\mathrm{Cl}_{2} \mathrm{Ca} .2 \mathrm{H}_{2} \mathrm{O}$

$0,3080 \mathrm{~g}$

ClMg.7 $\mathrm{H}_{2} \mathrm{O}$ (Solución 4M)

$0,0915 \mu \mathrm{l}$

Agua destilada

$10 \mathrm{ml}$

Osmolaridad (Solución 50 X)

369,15 mOsm

Esterilizar por filtración $(0,22 \mu \mathrm{m})$ y guardar a $4{ }^{\circ} \mathrm{C}$. Preparar cada 3 meses.

H-199 (Hepes-199: TCM-199 con 15 mM de Hepes y 5 mM de Bicarbonato de sodio)

\begin{tabular}{|lr|}
\hline 2 X TCM-199 & $300 \mathrm{ml}$ \\
\hline Hepes ácido & $1,44 \mathrm{~g}$ \\
\hline Hepes sódico & $1,56 \mathrm{~g}$ \\
\hline Bicarbinato de sodio & $0,25 \mathrm{~g}$ \\
\hline Agua destilada & $600 \mathrm{ml}$ \\
\hline Osmolaridad & $280 \mathrm{mOsm}$ \\
\hline Esterilizar por filtración $(0,22 \mu \mathrm{m})$ y guardar a $4^{\circ} \mathrm{C}$. Preparar cada semana \\
\hline
\end{tabular}

Bi-199 (Bicarbonato 199: TCM-199 con bicarbonato)

\begin{tabular}{|lr|}
\hline $2 \times \mathrm{TCM}-199$ & $50 \mathrm{ml}$ \\
\hline $\mathrm{NaHCO}_{3}$ & $0,2101 \mathrm{~g}$ \\
\hline Piruvato de sodio & $2,16 \mathrm{mg}$ \\
\hline Agua destilada & $100 \mathrm{ml}$ \\
\hline Osmolaridad ajustar a $280 \mathrm{mOsm}$ con agua ultrapura. \\
\hline Esterilizar por filtración $(0,22 \mu \mathrm{m})$ y guardar a $4{ }^{\circ} \mathrm{C}$. Preparar cada semana. \\
\hline
\end{tabular}


Stock sulfato de $\mathrm{Zinc}\left(\mathrm{ZnSO}_{4}\right)$

Solución de trabajo:

Solución Standard Zinc 1000 ppm (Cica-Merck Japón Cat. No. 48096-2B)

$1 \mathrm{ml}$

Agua destilada

Agregar $20 \mu \mathrm{l}, 40 \mu \mathrm{l}$ y $60 \mu \mathrm{l}$ de la solución de trabajo a $5 \mathrm{ml}$ del medio de maduración para obtener una concentración final de $0,7 \mu \mathrm{g} / \mathrm{ml} ; 1,1 \mu \mathrm{g} / \mathrm{ml}$ y $1,5 \mu \mathrm{g} / \mathrm{ml}$ de $\mathrm{Zn}$ respectivamente.

\section{Medios de cultivo}

Solución Fisiológica para el mantenimiento de los ovarios

\begin{tabular}{|lr|}
\hline $\mathrm{NaCl}$ & $9 \mathrm{~g}$ \\
\hline Penicilina & $59 \mathrm{mg}$ \\
\hline Estreptomicina & $100 \mathrm{mg}$ \\
\hline Kanamicina & $50 \mathrm{mg}$ \\
\hline Agua destilada & $1000 \mathrm{ml}$ \\
\hline Esterilizar por filtración $(0,22 \mu \mathrm{m})$ y guardar a $4^{\circ} \mathrm{C}$ & \\
\hline
\end{tabular}

Medio de aspiración de ovocitos

\begin{tabular}{|lr|}
\hline PBS (Solución buffer fosfato) & $100 \mathrm{ml}$ \\
\hline Stock de heparina & $0,5 \mathrm{ml}$ \\
\hline SFB (Suero Fetal Bovino) & $1 \mathrm{ml}$ \\
\hline Penicilina & $5,9 \mathrm{mg}$ \\
\hline Estreptomicina & $10 \mathrm{mg}$ \\
\hline Kanamicina & $5 \mathrm{mg}$ \\
\hline Esterilizar por filtración $(0,22 \mu \mathrm{m})$ y guardar a $4{ }^{\circ} \mathrm{C}$. Preparar cada semana. \\
\hline
\end{tabular}

Medio de mantenimiento de ovocitos 
Esterilizar por filtración $(0,22 \mu \mathrm{m})$ y guardar a $4{ }^{\circ} \mathrm{C}$. Preparar cada semana.

Medio para lavado de las gametas (Hepes-TALP)

\begin{tabular}{|lr|}
\hline $10 \times \mathrm{TL}$ & $10 \mathrm{ml}$ \\
\hline $\mathrm{NaHCO}_{3}$ & $6,8 \mathrm{mg}$ \\
\hline Stock H & $6 \mathrm{ml}$ \\
\hline $\mathrm{CaCl}_{2}$ & $30 \mathrm{mg}$ \\
\hline $\mathrm{MgCl}_{2} \cdot 6 \mathrm{H}_{2} \mathrm{O}(4 \mathrm{M})$ & $12,3 \mu \mathrm{l}$ \\
\hline Lactato de sodio & $141 \mu \mathrm{l}$ \\
\hline Piruvato de sodio & $88 \mathrm{mg}$ \\
\hline MEM-neaas (aminoácidos no esenciales) & $1 \mathrm{ml}$ \\
\hline BME-eaas (aminoácidos esenciales) & $2 \mathrm{ml}$ \\
\hline $\begin{array}{l}\text { ASB-FAF (Albúmina bovina sérica libre de } \\
\text { ácidos grasos) }\end{array}$ & $300 \mathrm{mg}$ \\
\hline Agua destilada & $100 \mathrm{ml}$ \\
\hline Osmolaridad & $270-290 \mathrm{mOsm}$ \\
\hline pH & 7,4 \\
\hline Esterilizar por filtración (0,22 $\mu$ m) y guardar a $4{ }^{\circ} \mathrm{C}$. Preparar cada 2 semanas. \\
\hline
\end{tabular}

Medio para lavado de embriones (Hepes-SOF)

\begin{tabular}{|lr|}
\hline Stock $\mathrm{S} 2$ & $11 \mathrm{ml}$ \\
\hline $\mathrm{NaHCO}_{3}$ & $16,8 \mathrm{mg}$ \\
\hline Stock $\mathrm{H}$ & $6 \mathrm{ml}$ \\
\hline Piruvato de sodio & $3,6 \mathrm{mg}$ \\
\hline $\mathrm{Cl}_{2} \mathrm{Ca}$ & $25,2 \mathrm{mg}$ \\
\hline $\mathrm{MgCl}_{2} \cdot 6 \mathrm{H}_{2} \mathrm{O}$ & $10 \mathrm{mg}$ \\
\hline
\end{tabular}




\begin{tabular}{|lr|}
\hline Lactato de sodio (60 \%) & $0,047 \mathrm{ml}$ \\
\hline Glucosa & $10,8 \mathrm{mg}$ \\
\hline BME-eaas & $2 \mathrm{ml}$ \\
\hline MEM-neaas & $300 \mathrm{mg}$ \\
\hline ASB-FAF & $100 \mathrm{ml}$ \\
\hline Agua destilada & $270-285 \mathrm{mOsm}$ \\
\hline Osmolaridad & 7,4 \\
\hline pH & \\
\hline Esterilizar por filtración $(0,22 \mu \mathrm{m})$ y guardar a $4{ }^{\circ} \mathrm{C}$. Preparar cada 2 semanas & \\
\hline
\end{tabular}

Medio de maduración in vitro

\begin{tabular}{|lr|}
\hline Preparar $10 \mathrm{ml}$ (Volumen final) en el momento de utilizar & \\
\hline Bi-199 & $8,9 \mathrm{ml}$ \\
\hline SFB & $20 \mu \mathrm{ml}(2 \mu \mathrm{g} / \mathrm{ml}$, Lutropin-V) \\
\hline Stock LH & $2 \mu \mathrm{g}(200 \mathrm{ng} / \mathrm{ml}$, Folltropin-V) \\
\hline FSH
\end{tabular}

Soluciones de Percoll para separación de espermatozoides

SPTL $1 X$

\begin{tabular}{|lr|}
\hline SPTL $10 X$ & $2,5 \mathrm{ml}$ \\
\hline SPAD & $0,2 \mathrm{ml}$ \\
\hline Agua estéril & $17,3 \mathrm{ml}$ \\
\hline Osmolaridad & $280-300 \mathrm{mOsm}$ \\
\hline $\mathrm{pH}$ & 7,3 \\
\hline
\end{tabular}

PERCOLL $90 \%$

Para $30 \mathrm{ml}$ :

Percoll $26,5 \mathrm{ml}$ 


\begin{tabular}{|lr|}
\hline SPTL $10 X$ & $2,95 \mathrm{ml}$ \\
\hline SPAD $100 \times$ & $0,295 \mathrm{ml}$ \\
\hline $\mathrm{NaHCO}_{3}$ & $6,2 \mathrm{mg}$ \\
\hline Osmolaridad & $280-300 \mathrm{mOsm}$ \\
\hline $\mathrm{pH}$ & 7,3 \\
\hline
\end{tabular}

PERCOLL $45 \%$

\begin{tabular}{|lr|}
\hline Percoll $90 \%$ & $2 \mathrm{ml}$ \\
\hline SPTL $1 X$ & $2 \mathrm{ml}$ \\
\hline
\end{tabular}

Medio para fecundación in vitro (Fert-TALP, Parrish y col., 1986).

\begin{tabular}{|lr|}
\hline TL 10 X & $5 \mathrm{ml}$ \\
\hline $\mathrm{NaHCO}_{3}$ & $0,101 \mathrm{mg}$ \\
\hline $\mathrm{CaCl}_{2} \cdot 6 \mathrm{H}_{2} \mathrm{O}$ & $15 \mathrm{mg}$ \\
\hline $\mathrm{MgCl}_{2} \cdot 6 \mathrm{H}_{2} \mathrm{O}(4 \mathrm{M})$ & $6,15 \mu \mathrm{l}$ \\
\hline Lactato de sodio & $70,5 \mu \mathrm{l}$ \\
\hline Piruvato de sodio & $1,44 \mathrm{ml}$ \\
\hline MEM-neaas & $0,5 \mathrm{ml}$ \\
\hline BME-eaas & $1 \mathrm{ml}$ \\
\hline ASB-FAF & $300 \mathrm{mg}$ \\
\hline Agua destilada & $50 \mathrm{ml}$ \\
\hline Osmolaridad & $280-300 \mathrm{mOsm}$ \\
\hline Esterilizar por filtración $(0,22 \mu \mathrm{m})$ y guardar a $4{ }^{\circ} \mathrm{C}$. Preparar cada 2 semanas \\
\hline
\end{tabular}

En el día de la fecundación:

\begin{tabular}{|lr|}
\hline Fert-TALP & $9,9 \mathrm{ml}$ \\
\hline Stock penicilamina & $50 \mu \mathrm{l}$ \\
\hline Stock hipotaurina & $50 \mu \mathrm{l}$ \\
\hline
\end{tabular}


Stock heparina

Medio para cultivo de embriones in vitro (SOFm, Tervit y col., 1972; Gardner y col., 1994)

\begin{tabular}{|lr|}
\hline Stock S2 & $2 \mathrm{ml}$ \\
\hline $\mathrm{NaHCO}_{3}$ & $42 \mathrm{mg}$ \\
\hline Piruvato de sodio & $0,72 \mathrm{ml}$ \\
\hline $\mathrm{MgCl}_{2} \cdot 6 \mathrm{H}_{2} \mathrm{O}(4 \mathrm{M})$ & $2,46 \mathrm{\mu l}$ \\
\hline $\mathrm{CaCl}_{2} \cdot 2 \mathrm{H}_{2} \mathrm{O}$ & $5,04 \mathrm{mg}$ \\
\hline Lactato de sodio & $9,40 \mu \mathrm{l}$ \\
\hline Glucosa* & $5,4 \mathrm{mg}$ \\
\hline Glutamina & $2,92 \mathrm{ml}$ \\
\hline MEM-neaas & $0,2 \mathrm{ml}$ \\
\hline BME-eaas & $0,4 \mathrm{ml}$ \\
\hline ASB-FAF & $160 \mathrm{mg}$ \\
\hline Agua destilada & $20 \mathrm{ml}$ \\
\hline pH & $7,2-7,4$ (en atmósfera gaseada) \\
\hline Osmolaridad & $265-275 \mathrm{mOsm}$ \\
\hline Esterilizar por filtración $(0,22 \mu \mathrm{m})$ y guardar a $4{ }^{\circ} \mathrm{C}$. Preparar cada $^{*}$ semana \\
\hline
\end{tabular}

*La glucosa será reemplazada por agua destilada para preparar el medio SOFm utilizado el primer día de cultivo. 
Bibliografía 
Abeydeera LR. In vitro production of embryos in swine. Theriogenology. 2002; 57 (1): 256 - 273.

Abeydeera LR, Day BN. Fertilization and subsequent development in vitro of pig oocytes inseminated in a modified trisbuffered medium with frozen-thawed ejaculated spermatozoa. Biol Reprod. 1997; 57: 729 -734.

Abeydeera LR, Wang WH, Cantley TC, Rieke A, Day BN. Coculture with follicular shell pieces can enhance the developmental competence of pig oocytes after in vitro fertilization: relevance to intracellular glutatione. Biol Reprod. 1998; 58: 213-218.

Abrieu A, Dorée M, Fisher D. The interplay between cyclin-B-Cdc2 kinase (MPF) and MAP kinase during maturation of oocytes. Journal of Cell Science. 2001; 114: 257 - 267.

Aerts JMJ, Bols PEJ. Ovarian Follicular Dynamics: A Review with Emphasis on the Bovine Species. Part I: Folliculogenesis and Pre-antral Follicle Development. Reprod Dom Anim. 2010; 45: $171-179$.

Aggett PJ, Comerford JG. Zinc and human health. Nutr Rev. 1995; 53: 16-22.

Agricultural Research Council (ARC). The Nutrient Requirements of Ruminant Livestock. Commonwealth Agricultural Bureaux, Farnham Royal, UK, 1980, p. 256 - 263.

Albertini DF, Carabatsos MJ. Comparative aspects of meiotic cell cycle control in mammals. J Mol Med. 1998; 76: $795-799$.

Albertini DF, Combelles CM, Benecchi E, Carabatsos MJ. Cellular basis for paracrine regulation of ovarian follicle development. Reproduction. 2001; 121: 647 - 653. 
Ali A, Paradis F, Vigneault C, Sirard M-A. The potential role of gap junction communication between cumulus cells and bovine oocytes during in vitro maturation. Molecular Reproduction and Development. 2005; 71: 358 - 367.

Alm H, Torner S, Blottern G, Kanitz W.Effect of sperm cryopreservation and treatment with calcium ionophore or heparin on in vitro fertilization of horse oocytes. Theriogenology. $2001 ; 56: 817-829$.

Almeida FR, Mao J, Novak S, Cosgrove JR, Foxcroft GR. Effects of different patterns of feed restriction and insulin treatment during the luteal phase on reproductive, metabolic, and endocrine parameters in cyclic gilts. J Anim Sci. 2001; 79 (1): 200 - 212.

Alvarez JG, Storey BT. Taurine, hypotaurine, epinephrine and albumin inhibit lipid peroxidation in rabbit spermatozoa and protect against loss of motility. Biol Reprod. 1983; 29 (3): 548 55.

Amălinei C, Căruntu ID, Bălan RA. Biology of metalloproteinases. Romanian Journal of Morphology and Embryology. 2007; 48 (4): 323 - 334.

Amleh A, Dean J. Mouse gentics provides insight into folliculogenesis, fertilization and early embryonic development. Hum Reprod Update. 2002; 8: 395 - 403.

Anderson E, Albertini DF. Gap junctions between the oocyte and companion follicle cells in the mammalian ovary. J Cell Biol. 1976; 71: 680 - 686.

Anderson R, Heasman J,Wylie C. Early events in the mammalian germ line. Int Rev Cytol. 2001; 203: $215-230$. 
Arshad HM, Ahmad N, Zia-ur-Rahman, Samad HA, Akhtar N, Ali S. Studies on some biochemical constituents of ovarian follicular fluid and peripheral blood in buffaloes. Pakistan Vet. J. 2005; 25 (4): 189 - 193.

Aruoma OI, Halliwell B, Hoey BM, Butler J. The antioxidant action of taurine, hypotaurine and their metabolic precursors. Biochem J. 1988; 256 (1): 251 - 255.

Ashworth CJ, Antipatis C. Micronutrient programming of development throughout gestation. Reproduction. 2001, 122 (4): 527-535.

Assidi M, Dufort I, Ali A, Hamel M, Algriany O, Dielemann S, Sirard MA. Identification of Potential Markers of Oocyte Competence Expressed in Bovine Cumulus Cells Matured with FollicleStimulating Hormone and/or Phorbol Myristate Acetate In Vitro. Biol Reprod. 2008; 79 (2): 209-222.

Austin CR. Observations on the penetration of the sperm into the mammalian egg. Aust $\mathrm{J}$ Sci Res [B]. 1951; 4: 581 - 596.

Ayalasomayajula SP, Kompella UB. Induction of vascular endothelial growth factor by 4hydroxynonenal and its prevention by glutathione precursors in retinal pigment epithelial cells. Eur J Pharmacol. 2002; 449 (3): 213 - 220.

Bachvarova R, Burns J, Speigelman I, Choy J, Chaganti R. Morphology and transcriptional activity of mouse oocyte chromosomes. Chromosoma. 1982; 86: 181 - 196.

Bachvarova R, De Leon V, Johnson A, Kaplan G, Paynton B. Changes in total RNA, polyadenylated RNA, and actin mRNA during meiotic maturation of mouse oocytes. Dev Biol. 1985; 108: 325 - 331. 
Bagavandoss P, Midgley AR, Wicha M. Developmental changes in the ovarian follicular basal lamina detected by immunofluorescence and electron microscopy. J. Histochem. Cytochem. 1983; 31: 633 - 640.

Baker T. Oogenesis and ovaries development. En: Balin H, Glasser S (Eds). Reproduction biology. Experta medica, Amsterdam, Holanda, 1972, p. 398-457.

Baker T. Oogenesis and ovulation. En: Austin C, Short R (Eds). Reproduction in mammals vol 1. Cambridge University Press, Cambridge, UK, 1982, p. 17-45.

Baker T, Franchi L. The fine structure of ovogonia and oocytes in human ovaries. J Cell Sci. 1967a; 2: $213-224$.

Baker T, Franchi L. The structure of chromosomes in bovine primordial oocytes. J Reprod Fertil. 1967b; 14: 511 - 513.

Barna J, Ashizawa K, Boldizs H, Inoue M. Effects of taurine on the motility and intracellular free Ca2+ concentration of fowl spermatozoa in vitro. J. Reprod. Fert. 1998; 114: 225 - 229.

Batinić-Haberle I, Rebouças JS, Spasojević I. Superoxide dismutase mimics: chemistry, pharmacology, and therapeutic potential. Antioxid Redox Signal. 2010; 13 (6): 877 - 918.

Bavister BD, Yanagimachi R, Teichman RJ. Capacitation of hamster spermatozoa with adrenal gland extracts. Biol Reprod. 1976; 14 (2): 219 - 221.

Bedford JM. Puzzles of mammalian fertilization - and beyond. Int. J. Dev. Biol. 2008; 52: 415 426. 
Bedford JM, Cooper GW. Membrane fusión events in fertilization of vertébrate eggs. En: G, Nicolson GL (Eds.) Membrane Surface Reviews (Membrane Fusion). Vol 5. Poste. NorthHolland, Amsterdam, 1978, p. 65 - 125.

Belenguer P, Caizerguues-Ferrer M, Labbe JC, Doreé M, Amalric F. Mitosis-specific phosphorilation of nucleolin by p34cdc2 protein kinase. Mol Cell Biol. 1990; 10: 3607 3618.

Belka C, Rudner J, Wesselborg S, Stepczynska A, Marini P, Lepple-Wienhues A, Faltin H, Bamberg M, Budach W, Schulze-Osthoff K. Differential role of caspase-8 and BID activation during radiation- and CD95-induced apoptosis. Oncogene. 2000; 19: 1181 1190.

Ben-Yosef D, Shalgi R. Early ionic events in activation of the mammalian egg. Rev Reprod. 1998; 3 (2): 96 - 103.

Bernhardt ML, Kim AM, O'Halloran TV, Woodruff TK. Zinc requirement during meiosis I-meiosis II transition in mouse oocytes is independent of the MOS-MAPK pathway. Biol Reprod. 2011; 84 (3): 526 - 536.

Beyersmann D, Haase $H$. Functions of zinc in signaling, proliferation and differentiation of mammalian cells. BioMetals. 2001; 14: $331-341$.

Bicknell GR, Snowden RT, Cohen GM. Formation of high molecular mass DNA fragments is a marker of apoptosis in human leukaemic cell line, U937. J. Cell. Sci. 1994; 107: 2483 2489.

Boatman DE, Robbins RS. Bicarbonate: carbon-dioxide regulation of sperm capacitation, hyperactivated motility, and acrosome reactions. Biol Reprod. 1991; 44 (5): 806 - 813. 
Bols PE. Puncture of immature ovarian follicles in bovine assisted reproduction. Verh $\mathrm{K}$ Acad Geneeskd Belg. 2005; 67 (3): 177 - 202.

Bonner JA, Ezekiel MP, Robert F, Meredith RF, Spencer SA, Waksal HW. Combinedresponse following treatment with IMC-C225, an EGFr MoAb, combinated with RT in advanced head and neck malignancies. Proceedings of the annual meeting of the American Society for clinical oncology, 2000, 19 A5F, 4a.

Borchelt DR, Lee MK, Slunt HS, Guarnieri M, Xu ZS, Wong PC, Brown RH, Jr, Price DL, Sisodia SS, Cleveland DW. Superoxide dismutase 1 with mutations linked to familial amyotrophic lateral sclerosis possesses significant activity. Proc Natl Acad Sci USA. 1994; 91 (17): $8292-8296$.

Borg N, Holland M. The effect of glycosaminoglycans on rat gametes in vitro and the associated signal pathway. Reproduction. 2008; 135 (3): 311 - 319.

Bornslaeger EA, Mattei P, Dchultz RM. Involvement of cAMP-dependent protein kinase and protein phosphorilation in regulation of mouse oocyte maturation. Dev Biol. 1986; 114: 453 $-462$.

Brackett RG, Bousquet D, Boice ML, Donawick WJ, Evans JF, Dressel MA. Normal development following in vitro fertilization in the cow. Biol Reprod. 1982; 27: 147 - 158.

Bray TM, Bettger WJ. The physiological role of zinc as an antioxidant. Free Radic Biol Med. 1990; 8: $281-291$.

Breitbart $\mathrm{H}$, Cohen $\mathrm{G}$, Rubinstein S. Role of actin cytoskeleton in mammalian sperm capacitation and the acrosome reaction. Reproduction. 2005; 129 (3): 263 - 268. 
Brogliatti GM, Adams GP. Ultrasound-guided transvaginal oocyte collection in prepubertal calves. Theriogenology. 1996; 45 (6): 1163 - 1176.

Brown EJ, Baltimore D. Essential and dispensable roles of ATR in cell cycle arrest and genome maintenance. Genes Dev. 2003; 17 (5): 615 - 628.

Bruinsma JJ, Jirakulaporn T, Muslin AJ, Kornfeld K. Zinc ions and cation diffusion facilitator proteins regulate Ras-mediated signaling. Dev Cell 2002; 2: 567-578.

Bruno RS, Song Y, Leonard SW, et al. Dietary zinc restriction in rats alters antioxidant status and increases plasma F2 isoprostanes. J Nutr Biochem. 2007; 18: 509 - 518.

Buccione R, Schoeder AC, Eppig JJ. Interaction between somatic cells and germ cells throughout mammalian oogenesis. Biol Reprod. 1990; 43: 543 - 547.

Buettner GR. Superoxide dismutase in redox biology: the roles of superoxide and hydrogen peroxide. Anticancer Agents Med Chem. 2011; 11 (4): 341 - 346.

Bukovsky A, Caudle MR, Svetlikova M, Upadhyaya NB. Origin of germ cells and formation of new primary follicles in adult human ovaries. Reproductive Biology and Endocrinology. 2004; 2: 20.

Burghardt RC, Anderson E. Hormonal modulation of gap junctions in rat ovarian follicles. Cell Tissue Res. 1981; 214: 181 - 193.

Byskov A. Primordial germ cells and regulation of meiosis. En: Austin C, Short R (Eds) Reproduction in mammals vol1. Cambridge University Press, Cambridge, UK, 1982, p. 1 16.

Callejas SS. Fisiología del ciclo estral bovino. Revista Cabia. 1996; 29:10 - 24. 
Calvin HI, Grosshans K, Blake EJ. Estimation and manipulation of glutathione levels in prepuberal mouse ovaries and ova: relevance to sperm nucleus transformation in the fertilized egg. Gamete Res. 1986; 14: 265 - 275.

Camaioni A, Hascall VC, Yanagishita M, Salustri A. Effects of exogenous hyaluronic acid and serum on matrix organization and stability in the mouse cumulus cell-oocyte complex. $\mathrm{J}$ Biol Chem. 1993; 268 (27): 20473 - 20481.

Campbell C, Quinn AG, Angus B, Farr PM, Rees JL. Wavelength specific patterns of p53 induction in human skin following exposure to UV radiation. Cancer Res. 1993; 53: 2697 2699.

Canali R, Vignolini F, Nobili F, Mengheri E. Reduction of oxidative stress and cytokine-induced neutrophil chemoattractant (CINC) expression by red wine polyphenols in zinc deficiency induced intestinal damage of rat. Free Radic Biol Med. 2000; 28: 661 - 670.

Cao J, Henry PR, Guo R, Holwerda RA, Toth JP, Littell RC, Miles RD, Ammerman CB. Chemical characteristics and relative bioavailability of supplemental organic zinc sources for poultry and ruminants. J Anim Sci. 2000; 78 (8): 2039 - 2054.

Cardona Maya WD, Olivera Ángel M, Cadavid AP. Evaluación de la reacción acrosomal inducida por el ionóforo de calcio: una aproximación más real de la capacidad fecundante del espermatozoide. Arch. Esp. Urol. 2006; 59 (5): 501 - 510.

Carolan C, Lonergan P, Van Langendonckt A, Mermillod P. Factors affecting bovine embryo development in synthetic oviduct fluid following oocyte maturation and fertilization in vitro. Theriogenology. 1995; 43: 1115 - 1128. 
Carroll J. Na+-Ca2+ exchange in mouse oocytes: modifications in the regulation of intracellular free Ca2+ during oocyte maturation. J Reprod Fert. 2000, 118: 337 - 342.

Cathomen T, Joung JK. Zinc-finger nucleases: the next generation emerges. Mol Ther. 2008; 16: $1200-1207$.

Chai F, Truong-Tran AQ, Ho LH and Zalewski PD. Regulation of caspase activation and apoptosis by cellular zinc fluxes and zinc deprivation: a review. Immunol Cell Biol. 1999; 77: $272-278$.

Chakravarthi S, Catherine E, Jessop CE, Bulleid NJ.The role of glutathione in disulphide bond formation and endoplasmic-reticulum-generated oxidative stress. EMBO reports. 2006; 7 : $271-275$.

Chang LY, Slot JW, Geuze HJ, Crapo JD. Molecular immunocytochemistry of the CuZn superoxide dismutase in rat hepatocytes. J. Cell Biol. 1988; 107: $2169-2179$.

Chang MC. Fertilizing capacity of spermatozoa deposited into the fallopian tube. Nature. 1951; 168: $697-698$.

Chang MC. In vitro fertilization of mammalian eggs. J Animal Sci. 1968; 27 (Suppl 1): 15 - 22.

Chang MC. The meaning of sperm capacitation. A historical perspective. J Androl. 1984; 5 (2): $45-50$.

Chang MC, Austin CR, Bedford JM, Brackett BG, Hunter RHF, Yanagimachi R. Capacitation of spermatozoa and fertilization in mammals. En: Greep RO, Kobrinsky MA (Eds) Frontiers in Reproduction and Fertility Control. Part 2. Ford Foundation Publications, Cambridge, UK, $1977 ; 434-451$. 
Chase CC, Kirby CJ, Hammond AC, Olson TA, Lucy MC. Patterns of ovarian growth and development in cattle with a growth hormone deficiency. J Anim Sci. 1998; 76: 212 -219.

Chen L, Mao SJ, Larsen WJ. Identification of a factor in fetal bovine serum that stabilizes the cumulus extracellular matrix. A role for a member of the inter-alpha-trypsin inhibitor family. J Biol Chem. 1992; 267: $12380-12386$.

Chen L, Russell PT, Larsen WJ. Functional significance of cumulus expansion in the mouse: roles for the preovulatory synthesis of hyaluronic acid within the cumulus mass. Mol Reprod Dev. 1993; 34: 87 - 93.

Chen L, Wert SE, Hendrix EM, Rusell PT, Cannon M, Larsen WJ. Hyaluronic acid synthesis and gap junction endocytosis are necessary for normal expansion of the culture mass. Mol Reprod Dev, 1990; 26: 236 - 247.

Chen L, Zhang H, Powers RW, Russell PT, Larsen WJ. Covalent linkage between proteins of the inter-alpha-inhibitor family and hyaluronic acid is mediated by a factor produced by granulosa cells. J Biol Chem. 1996; 271: 19409 - 19414.

Chen X, Zhou B, Yan J, Xu B, Tai P, Li J, Peng S, Zhang M, Xia G. Epidermal growth factor receptor activation by protein kinase $\mathrm{C}$ is necessary for $\mathrm{FSH}$-induced meiotic resumption in porcine cumulus-oocyte complexes. Journal of Endocrinology. 2008; 197: 409 - 419.

Chen Y, Maret W. Catalytic selenols couple the redox cycles of metallothionein and glutathione. Eur J Biochem. 2001; 268: 3346 - 3353.

Cheng WTK, Moor RM, Polge C. In vitro fertilization of pig and sheep oocytes matured in vivo and in vitro. Theriogenology. 1986; 25: 140 - 146. 
Chihuailaf RH, Contreras PA, Wittwer FG. Patogénesis del estrés oxidativo: Consecuencias y evaluación en salud animal. Vet. Méx. 2002; 33 (3).

Chimienti F, Aouffen M, Favier A and Seve M. Zinc homeostasis regulating proteins: new drug targets for triggering cell fate. Curr Drug Targets. 2003; 4: 323 - 338.

Chimienti F, Jourdan E, Favier A, Seve M. Zinc resistance impairs sensitivity to oxidative stress in HeLa cells: protection through metallothioneins expression. Free Radic Biol Med. 2001; 31 (10): 1179 - 1190.

Christian CA, Moenter SM. The Neurobiology of Preovulatory and Estradiol-Induced Gonadotropin-Releasing Hormone Surges. Endocrine Reviews. 2010; 31: 544 - 577.

Chung YC, Kim CK, Kim HR, Lee JH, Chung JT. Effect of individual variation in acrosome reaction of bull sperm on in vitro fertilization and embryonic development. J Anim Sci. 1991; 69 (1): 427.

Clark J, Eddy E. Fine structural abservations on the origin and association of primordial germ cells of the mouse. Dev Biol. 1975; 47: 136 - 155.

Clark SG, Haubert K, Beebe DJ, Fergusona E, Wheeler MB. Reduction of polyspermic penetration using biomimetic microfluidic technology during in vitro fertilization. The Royal Society of Chemistry. 2005; 5: 1229 - 1232.

Clarke AR, Gledhill S, Hooper ML, Bird CC, Wyllie AH (1994). p53 dependence of early apoptotic and proliferative responses within the mouse small intestinal epithelium following irradiation. Oncogene. 1994; 9: 1767 - 1773. 
Cohen JJ, Duke RC. Glucocorticoid activation of a calcium-dependent endonuclease in thymocyte nuclei leads to cell death. J. Immunol. 1984; 132: 38 - 42.

Cohen JJ. Apoptosis. Immunol. Today. 1993, 14: 126 -130.

Collins AR. The comet assay for DNA damage and repair: principles, applications, and limitations. Mol Biotechnol. 2004; 26: 249 - 261.

Conte D, Narindrasorasak S, Sarkar B. In vivo and in vitro iron replaced zinc finger generates free radicals and causes DNA damage. J Biol Chem. 1996; 271: 5125 - 5130.

Corn CM, Hauser-Kronberger C, Moser M, Tews G, Ebner T. Predictive value of cumulus cell apoptosis with regard to blastocyst development of corresponding gametes. Fertil Steril. 2005; $84(3): 627$ - 633.

Cortese MM, Suschek CV, Wetzel W, Kröncke KD, Kolb-Bachofen V. Zinc protects endothelial cells from hydrogen peroxide via Nrf2-dependent stimulation of glutathione biosynthesis. Free Radic Biol Med. 2008; 44 (12): 2002 - 2012.

Cortese-Krott MM, Suschek CV, Wetzel W, Kröncke KD, Kolb-Bachofen V. Nitric oxide-mediated protection of endothelial cells from hydrogen peroxide is mediated by intracellular zinc and glutathione. Am J Physiol Cell Physiol. 2009; 296 (4): 811 - 820.

Cortvrindt R, Hu Y, Smitz J. Recombinant luteinizing hormone as a survival and differentiating factor increases oocyte maturation in recombinant follicle stimulated hormonesupplemented mouse preantral follicle culture. Hum Reprod. 1998; 13: 1292 - 1303. 
Coskun S, Uzumcu M, Lin YC, Friedman Cl, Alak BM. Regulation of cumulus cell steroidogenesis by the porcine oocyte and preliminary characterization of oocyte-produced factor(s). Biol Reprod. 1995; 53: 670 - 675.

Cousins RJ. Cinc. En: Ziegler EE, Filer LJ Conocimientos actuales sobre nutrición. Séptima Edición. Washington: International Life Sviences Institute, USA, 1999, p. 312 - 327.

Cousins RJ, Blanchard RK, Moore JB, Cui L, Green CL, Liuzzi JP, Cao J, Bobo JA. Regulation of zinc metabolism and genomic outcomes. J Nutr. 2003; 133: 1521 - 1526.

Cousins RJ, Liuzzi JP, Lichten LA. Mammalian zinc transport, trafficking, and signals. J Biol Chem. 2006; 281 (34): 24085 - 24089.

Coy P, Martínez E, Ruíz S, Vázquez JM, Roca J, Matas C, Pellicer MT. In vitro fertilization of pig oocyte after different coincubation intervals. Theriogenology. 1993; 39: 1201 - 1208.

Cran DG. The distribution of organelles in mammalian oocytes following centrifugation prior to injection of foreign DNA. Gamete Res. 1987; 18 (1): 67 - 76.

Cran DG, Cheng WTK. The cortical reaction in pig oocytes during in vivo and in vitro fertilization. Gamete Research. 1986; 13: 241 - 251.

Crozet N, Ahmed-Ali M, Dubos MP. Developmental competence of goat oocytes from follicles of different size categories following maturation, fertilization and culture in vitro. J Reprod Fertil. 1995; 103: 293 - 298.

Crozet N, Huneau D, De Smedt V, Theron MC, Szollosi D, Torres S, Sevellec C. In vitro fertilization with normal development in sheep. Gametes Res. 1987; 16: 159 - 170. 
Cuomo A, Di Cristo C, Di Cosmo A, Paolucci M, Tosti E. Calcium currents correlate with oocyte maturation during the reproductive cycle in Octopus vulgaris. J Exp Zool A. 2005, 303: 193 $-202$.

Czerski L, Nuñez G. Apoptosome formation and Caspase activation: is it different in the heart?. J Mol Cell Cardiol. 2004; 37 (3): 643 - 652.

Dan JC. Sperm entrance in echinoderms, observed with the phase contrast microscope. Biol. Bull. 1950; 99: 399-411.

David GF, Anand Kumar TC, Baker TG. Uptake of tritiated thymidne by primordial germinal cells in the ovaries of the adult slender loris. J Reprod Fertil. 1974; 41: $447-451$.

David JE. Zinc transporters and the cellular trafficking of zinc. Biochimica et Biophysica Acta. 2006; 1763: $711-722$.

de Matos DG, Furnus CC. The importance of having high glutathione (GSH) level after bovine in vitro maturation on embryo development: effect of $\beta$-mercaptoethanol, cysteine and cystine. Theriogenology. 2000; 53: 761 - 771.

de Matos DG, Furnus CC, Moses DF. Glutathione synthesis during in vitro maturation of bovine oocytes: role of cumulus cells. Biology of Reproduction 1997, 57: 1420-1425.

de Matos DG, Furnus CC, Moses DF, Baldassarre H. Effect of cysteamine on glutathione level and developmental capacity of bovine oocyte matured in vitro. Mol Reprod Dev. 1995; 42 (4): $432-436$. 
de Matos DG, Furnus CC, Moses DF, Martinez AG, Matkovic M. Stimulation of glutathione synthesis of in vitro matured bovine oocytes and its effect on embryo development and freezability. Mol Reprod Dev. 1996; 45: $451-457$.

de Rosa G, Keen CL, Leach RM, Hurley LS. Regulation of superoxide dismutase activity by dietary manganese. J Nutr. 1980; 110 (4): 795 - 804.

Dekel N, Beers WH. Development of the rat oocyte in vitro: inhibition and induction of maturation in the presence or absence of the cumulus oophorus. Dev. Biol. 1980; 75: 247 - 254.

Dell'Aquila ME, Cho YS, Minoia P, Traina V, Fusco S, Lacalandra GM, Maritato F. Intracytoplasmic sperm injection (ICSI) versus conventional IVF on abattoir-derived and in vitro-matured equine oocytes. Theriogenology. 1997; 47: 1139 - 1156.

Dell'Aquila ME, De Felici M, Massari S, Maritato F, Minoia P. Effects of Fetuin on zona pellucida hardening and fertilizability of equine oocytes matured in vitro. Biol Reprod. 1999; 61: 533 $-540$.

Dickinson DA, Forman HJ. Cellular glutathione and thiols metabolism. Biochem Pharmacol. 2002; 64 (5-6): 1019 - 1026.

Doree M. Control of M-phase by maturation- promoting factor. Curr Opinion Cell Biol. 1990; 2: $269-273$.

Downs SM. Purine control of mouse oocyte maturation: evidence that nonmetabolized hypoxanthine maintains meiotic arrest. Mol Reprod Dev. 1993; 35: 82 - 94.

Dreosti IE. Zinc and the gene. Mutat Res. 2001; 475: 161-167. 
Driancourt MA. Regulation of ovarian follicular dynamics in farm animals. Implications for manipulation of reproduction. Theriogenology. 2001; 55: 1211 - 1239.

Driancourt MA, Reynaud K, Cortvrindt R, Smitz J. Roles of kit and kit ligand in ovarian function. Rev Reprod. 2000; 5: 143 - 152.

Drion PV, Beckers JF, Ectors FJ, Hanzen C, Houtain JY, Lonergan P. Regulation in follicular and luteal growth: 1. Folliculogenesis and atresia. Le Point Veterinaire. 1996; 28: 881 891.

Dunphy WG, Brizuela L, Beach D, Newport J. The Xenopus cdc2 protein is a component of MPF, a cytoplasmatic regulator of mitosis. Cell. 1988; 54: 423 - 431.

Eddy EM. En: The Physiology of Reproduction. Knobil E. Neill JD (Eds). Elsevier/Academic Press, Amsterdam, Boston, 2006, p. 3 - 54.

Eddy EM, O’Brien DA. The spermatozoon. En: Knobil E, Neill JD (Eds.) The physiology of reproduction.. Raven Press, New York, USA, 1994, p. 30 - 60.

Edelstam GA, Lundkvist OE, Wells AF, Laurent TC. Localization of hyaluronan in regions of the human female reproductive tract. J Histochem Cytochem. 1991; 39 (8): 1131 - 1135.

Edson MA, Nagaraja AK, Matzuk MM. The mammalian ovary from genesis to revelation. Endocr Rev. 2009; 30 (6): 624 - 712.

Edwards RG. Human embryos in vitro: pioneer illustrations of oocyte maturation, fertilization, cleavage and blastulation. Human Reproduction. 2000; 15 (4): 1 - 9.

Edwards RG, Beard HK. Oocyte polarity and cell determination in early mammalian embryos. Mol.nHuman Reprod. 1997; 3 (10): 863 - 905. 
Eichenlaub-Ritter $U$, Peschke M. Expression in in-vivo and in-vitro growing and maturing oocytes: focus on regulation of expression at the translational level. Hum Reprod Update. 2002; 8: $21-41$.

Eide DJ. The SLC39 family of metal ion transporters. Eur J Physiol. 2004; 447: 796 - 800.

Eide DJ. Zinc transporters and the cellular trafficking of zinc. Biochim Biophys Acta. 2006; 1763 : $711-722$.

Eisenbach M, Giojalas LC. Sperm guidance in mammals - an unpaved road to the egg. Nat Rev Mol Cell Biol. 2006; 7(4): 276 - 85.

Elchuri S, Oberley TD, Qi W, Eisenstein RS, Jackson Roberts L, Van Remmen H, Epstein CJ, Huang TT. CuZnSOD deficiency leads to persistent and widespread oxidative damage and hepatocarcinogenesis later in life. Oncogene. 2005; 24: 367 - 380.

Elder K, Dale B. Sperm-oocyte interaction. En: In vitro fertilization. Tercera edición. Cambridge University Press, UK, 2011.

Elmore S. Apoptosis: a review of programmed cell death. Toxicol Pathol. 2007; 35 (4): 495 516.

Emonet-Piccardi N, Richard MJ, Ravanat JL, Signorini N, Cadet J, Beani JC. Protective effects of antioxidants against UVAinduced DNA damage in human skin fibroblasts in culture. Free Radic Res. 1998; 29: 307 - 313.

Engle TE, Nockels CF, Kimberling CV, Weaber DL, Johnson AB. Zinc repletion with organic or inorganic forms of zinc and protein turnover in marginally zinc-deficient calves. J Anim Sci. 1997; 75 (11): 3074 - 3081. 
Eppig J. Role of serum in FSH stimulated cumulus expansion by mouse oocyte-cumulus cellcomplex in vitro. Biol Reprod. 1980; 22: 692 - 633.

Eppig JJ, Downs SM. Chemical Signals that Regulate Mammalian Oocyte Maturation. Biology of Reproduction. 1984; 30: 1 - 11.

Eppig JJ. Intercommunication between mammalian oocytes and companion somatic cells. Bioessays. 1991; 13: $569-574$.

Eppig JJ. Coordination of nuclear and cytoplasmic oocyte maturation in eutherian mammals. Reprod. Fertil. Dev. 1996; 8: 485 - 489.

Erickson EA, Hubbard M, Hubbard NE. Micronutrients and Innate Immunity Kent L. The Journal of Infectious Diseases. 2000; 182 (1): 5 - 10.

Estévez AG, Crow JP, Sampson JB, Reiter C, Zhuang Y, Richardson GJ, Tarpey MM, Barbeito L, Beckman JS. Induction of nitric oxide-dependent apoptosis in motor neurons by zincdeficient superoxide dismutase. Science. 1999; 286 (5449): 2498 - 2500.

Eynard AR, Valentich MA, Rovasio RA. Componentes celulares y moleculares involucrados en etapas tempranas del desarrollo. En: Histología y embriología del ser humano: bases celulares y moleculares. Editorial Médica Panamericana, Argentina, 2008, p. 140 - 168.

Falchuk $\mathrm{KH}$. The molecular basis for the role of zinc in developmental biology. Mol Cell Biochem. 1998; 188: $41-48$.

Falchuk KH, Montorzi M. Zinc physiology and biochemistry in oocytes and embryos. Biometals. 2001; 14: $385-395$. 
Falchuk $\mathrm{KH}$, Montorzi M, Vallee BL. Zinc uptake and distribution in Xenopus laevis oocytes and embryos. Biochemistry. 1995; 34: $16524-16531$.

Fan HY, Sun QY. Involvement of Mitogen-Activated Protein Kinase Cascade During Oocyte Maturation and Fertilization in Mammals. Biology of Reproduction. 2004; 70: 535 - 547.

Fatehi AN, Zeinstra EC, Kooij RV, Colenbrander B, Bevers MM. Effect of cumulus cell removal of in vitro matured bovine oocytes prior to in vitro fertilization on subsequent cleavage rate. Theriogenology. 2002; 57: $1347-1355$.

Field LS, Furukawa Y, O'Halloran TV, Culotta VC. Factors controlling the uptake of yeast copper/zinc superoxide dismutase into mitochondria. J. Biol. Chem. 2003; 278: 28052 28059.

Findlay JK, Drummond AE, Dyson ML, Baillie AJ, Robertson DM, Ethier J-F. Recruitment and development of the follicle; the roles of the transforming growth factor-b superfamily. Mol Cell Endocrinol. 2002; 191: $35-43$.

Fleming AD, Yanagimachi R. Fertile life of acrosome-reacted guinea pig spermatozoa. J Exp Zool. 1982; 220 (1): 109 -115. (Abstract)

Fletcher WH, Greenan JRT. Receptor mediated action without receptor occupancy. Endocrinology. 1985; 116: 1660 - 1662.

Florman HM, Ducibella T. En: Knobil E. Neill JD (Eds) The Physiology of Reproduction. Elsevier/Academic Press, Amsterdam, Boston, 2006, p. 55 - 112.

Fortune JE, Rivera GM, Evans ACO, Turzillo AM. Differentiation of dominant versus subordinate follicles in cattle. Biol Reprod. 2001; 65: 648 - 654. 
Fraser LR. Potassium ions modulate expression of mouse sperm fertilizing ability, acrosome reaction and hyperactivated motility in vitro. J Reprod Fertil. 1983; 69 (2): 539 - 553.

Fraser LR, Quinn PJ. A glycolytic product is obligatory for initiation of the sperm acrosome reaction and whiplash motility required for fertilization in the mouse. J Reprod Fertil. 1981; $61(1): 25-35$.

Freeman B. The active migration of germ cells in the embryos of mice and men is a myth. Reproduction. 2003; 125: $635-643$.

Freeman BA, Crapo JD. Biology of disease: free radical and tissue injury, Lab. Invest. 1982; 47: $412-426$.

Fujimoto $\mathrm{Y}$, Yoshinaga K, Kono I. Distribution of fibronectin on the migratory pathway of primordial germ cells in mice. Anat Rec. 1985; 211: 271 - 278.

Fukui Y, Sonoyama T, Mochizucki H, Ono H. Effect of heparin dosage and sperm capacitation time on in vitro fertilization and cleavage of bovine oocytes maturated in vitro, Theriogenology. 1990, 34: 575 - 591.

Fulka JJr, Liebfried-Rutledge ML, First NL. Effect of 6-dimethylaminopurine on germinal vesicle breakdown of bovine oocytes. Molec. Reprod. Develop. 1991; 29 (4): 379 - 384.

Funahashi H, Cantley TC, Day BN. Different hormonal requirements of pig oocytecumulus complexes during maturation in vitro. J Reprod Fertil. 1994; 101: 159 - 165.

Funahashi H, Day BN. Effects of the duration of exposure to hormone supplements on cytoplasmic maturation of pig oocytes in vitro. J Reprod Fertil. 1993; 98: 179 -185. 
Funahashi H, Day BN. Advances in in-vitro production of porcine embryos. J Reprod Fertil. 1997; 52 (Suppl): 271 - 283.

Funahashi H, Kim NH, Stumpf TT, Cantley TC, Day BN. Presence of organic osmolytes in maturation medium enhances cytoplasmic maturation of porcine oocytes. Biol Reprod. 1996; 54: 1412 - 1419.

Furnus CC, de Matos DG, Moses DF. Cumulus expansion during in vitro maturation of bovine oocytes: relationship with intracellular glutathione level and its role on subsequent embryo development. Mol Reprod Dev. 1998; 51: 76 - 83.

Furnus CC, de Matos DG, Picco S, García PP, Inda AM, Mattioli G, Errecalde AL. Metabolic requirements associated with GSH synthesis during in vitro maturation of cattle oocytes. Anim Reprod Sci. 2008; 109: 88 - 99.

Gabrielli BG, Roy LM, Maller JL. Requirement of cdk2 in cytostatic factor-mediated metaphase arrest. Science. 1993; 259: 1766 - 1769.

Gadella BM, Tsai PS, Boerke A, Brewis IA. Sperm head membrane reorganization during capacitation. Int. J. Dev. Biol. 2008; 52: $473-480$.

Gardiner CS, Reed DJ. Status of glutathione during oxidant-induced oxidative stress in the preimplantation mouse embryo. Biol Reprod. 1994; 51 (6): 1307 - 1314.

Gardiner CS, Salmen JJ, Brandt CJ, Stover SK. Glutathione is present in reproductive tract secretions and improves development of mouse embryos after chemically induced glutathione depletion. Biol Reprod. 1998; 59 (2): 431 - 436. 
Gardner DK, Lane M, Spitzer A, Batt PA. Enhanced rates of cleavage and development for sheep zygotes cultured to the blastocyst stage in vitro in the absence of serum and somatic cells: Amino acids, vitamins, and culturing embryos in groups stimulated development. Biol Reprod. 1994; 50: 390 - 400.

Garrett WM, Guthrie HD. Expression of Bcl-2 and 3-hydroxysteroid dehydrogenase protein during oocyte and follicle development in foetal and post-natal pig ovaries. Reprod Fertil Dev. 1999; 11: $463-470$.

Garrido C, Saule S, Gospodarowicz D. Transcriptional regulation of vascular endothelial growth factor gene expression in bovine granulosa cells. Growth Factors. 1993; 8: 109 - 117.

Gautier J, Norbury C, Lohka M, Maller J. Purified maturation promoting factor contains the product of a Xenopus homolog of the fussion yeast cell cycle gene cdc2+. Cell. 1988; 54: 433 - 439.

Ge L, Han D, Lan GC, Zhou P, Liu Y, Zhang X, Sui HS, Tan JH. Factors affecting the in vitro action of cumulus cells on the maturing mouse oocytes. Mol Reprod Dev. 2008; 75 (1): $136-42$.

Gerard N, Loiseau S, Duchamp G, Seguin F. Analysis of the variations of follicular fluid composition during follicular growth and maturation in the mare using proton nuclear magnetic resonance. Reproduction. 2002; 124: 241 - 248.

Gifford SR, Clydesdale FM. Interactions Among Calcium, Zinc and Phytate with Three Protein Sources. Journal of food science. 1990; Volume 55, No. 6. 
Gil Corbalán MA. Influencia de diferentes condiciones de cocultivo sobre la fecundación y la producción in vitro de embriones porcinos. Tesis doctoral. Facultad De Veterinaria, Universidad de Murcia. 2001.

Gil MA, Cuello C, Parrilla I, Vazquez JM, Roca J, Martinez EA. Advances in swine in vitro embryo production technologies. Reprod Domest Anim. 2010; 45 (2): 40 - 48.

Gil Villa AM, Cardona-Maya WD, Cadavid Jaramillo AP. Muerte embrionaria temprana: ¿tiene influencia el factor masculino?. Arch. Esp. Urol. 2007; 60 (9): 1057 - 1068.

Gilbert SF. Fecundación: el comienzo de un nuevo organismo. En: Gilbert SF Biología del desarrollo. Editorial Médica Panamericana SA, Argentina, 2005a, p. 197- 238.

Gilbert SF. Desarrollo temprano en los vertebrados: peces, aves y mamíferos. En: Gilbert SF Biología del desarrollo. Editorial Médica Panamericana SA, Argentina, 2005b, p. 371 419.

Gilchrist RB, Lane M, Thompson JG. Oocyte-secreted factors: regulators of cumulus cell function and oocyte quality. Human Reprod Update. 2008; 14 (2): 155 - 177.

Gilchrist RB, Ritter LJ, Armstrong DT. Oocyte-somatic cell interactions during follicle development in mammals. Anim Reprod Sci. 2004; 82 - 83: 431 - 446.

Gilula N, Epstein M, Beers W. Cell-to-cell communication and ovulation and ovulation: A study of cumulus cell-oocyte complex. J Cell Biol. 1978; 78 : 58 - 75.

Ginsburg M, Snow MHL, McLaren A. Primordial germ cells in the mouse embryo during gastrulation. Development. 1990; 110: 521 - 528. 
Glander $\mathrm{HJ}$ y Schaller J. Binding of annexin $\mathrm{V}$ to plasma membranes of human spermatozoa: a rapid assay for detection of membrane changes after cryostorage. Mol Hum Reprod. 1999; 5: $109-115$.

Godin I, Wylie C. TGF $\beta 1$ inhibits proliferation and has a chemostactic effect on mouse primordial germ cells in culture. Development. 1991; 113: 1451 - 1457.

Godin I, Wylie C, Heasman J. Genital ridges exert long-range effects on primordial germ cell numbers and direction of migration in culture. Development. 1990; 108: 357 - 363.

Goldberg JM, Falcone T, Attaran M. In vitro fertilization update. Cleve Clin J Med. 2007; 74 (5): $329-338$.

Gordon I. Embryo transfer and associated techniques in cattle. En: Gordon I (ed.) Controlled Reproduction in Cattle and Buffaloes. CAB International, University Press, Cambridge, UK, 1996, p. $245-371$.

Goud PT, Goud AP, Qian C, Laverge H, Van der Elst J, De Sutter P, Dhont M. In-vitro maturation of human germinal vesicle stage oocytes: role of cumulus cells and epidermal growth factor in the culture medium. Hum. Reprod. 1998; 13: 1638 - 1644.

Goudet G, Mugnier S, Callebaut I, Monget P. Phylogenetic analysis and identification of pseudogenes reveal a progressive loss of zona pellucida genes during evolution of vertebrates. Biol Reprod. 2008; 78 (5): 796 - 806.

Graham TW, Thurmond MC, Gershwin ME, Picanso JP, Garvey JS, Keen CL. Serum zinc and copper concentrations in relation to spontaneous abortion in cows: implications for human fetal loss. J Reprod Fertil. 1994; 102: 253 - 262. 
Grahn BH, Paterson PG, Gottschall-Pass KT, Zhang Z. Zinc and the Eye. Journal of the American College of Nutrition. 2001; 20 (2): 106 - 118.

Grazul-Bilska AT, Reynolds LP, Redmer DA. Gap junctions in the ovaries. Biol Reprod 1997; 57: $947-957$.

Gunshin H, Mackenzie B, Berger UV, Gunshin Y, Romero MF, Boron WF, Nussberger S, Gollan JL, Hediger MA. Cloning and characterization of a mammalian proton-coupled metal-ion transporter. Nature 1997; 388 (6641): 482 - 488.

Gupta SK, Bhandari B. Acrosome reaction: relevance of zona pellucida glycoproteins. Asian Journal of Andrology. 2011; 13: 97 - 105.

Guthrie HD, Garrett WM. Apoptosis during folliculogenesis in pigs. Reproduction. 2001; 58: 17 29.

Guzmán L, Pérez S, Valdivia M. Induction of the acrosomal reaction in mouse spermatozoa by the solution of pellucid zone from alpaca (Lama pacos L.). Rev. perú. biol. 2007; número especial 13 (3): $227-229$.

Habibi B, Franchi L. Fine-structural changes in the nucleus of primordial oocytes in immature hamsters. J Cell Sci. 1978; 34: 209 - 223.

Hafez ESE. Reproducción e inseminación artificial en animales. 6ta edición. Ed Interamericana, 1996, p. 542.

Hahnel AC, Eddy EM. Cell surface markers of mouse primordial germ cells defined by two monoclonal antibodies. Gamete Res. 1986; 15: 25 - 34. 
Hake LE, Richter JD. Translational regulation of maternal mRNA. Biochem Biophys Acta. 1997, 1332: 31 - 38.

Halfter W, Schurer B, Hasselhorn HM, Christ B, Gimpel E, Epperlein HH. An ovomucin-like protein on the surface of migrating primordial germ cells of the chick and rat. Development. 1996; 122: 915 - 923.

Hanada A, Enya Y, Suzuki T. Birth of calves by non-sirurgical transfer of in vitro fertilized embryos obtained from oocytes matured in vitro. Japanese J. Anim Reprod. 1986; 32: 208 (Abst).

Hartshorne GM. In vitro culture of ovarian follicles. Rev Reprod. 1997; 2: 94 - 104.

Hashimoto S. Application of in vitro maturation to assisted reproductive technology. J Reprod Dev. 2009; 55: 1 - 10.

Hashimoto S, Minami N, Yamada M, Imai H. Excessive concentration of glucose during in vitro maturation impairs the developmental competence of bovine oocytes after in vitro fertilization: relevance to intracellular reactive oxygen species and glutathione contents. Mol. Reprod. Dev. 2000; 56: 520 - 526.

Hashimoto S, Saeki K, Nagao Y, Minami N, Yamada M, Utsumi K. Effects of cumulus cell density during in vitro maturation on the developmental competence of bovine oocytes. Theriogenology. 1998; 49: 1451 - 1463.

Heikinheimo O, Gibbons WE. The molecular mechanisms of oocyte maturation and early embryonic development are unveiling new insights into reproductive medicine. Molecular Human Reproduction. 1998; 4 (8): 745 - 756. 
Hertelendy F, Nemecz G, Molnár M. Influence of follicular maturation on luteinizing hormone and guanosine 5'-O-thiotriphosphate-promoted breakdown of phosphoinositides and calcium mobilization in chicken granulosa cells. Biol Reprod. 1989; 40 (6): 1144- 1151.

Hess KA, Chen L, Larsen WJ. Inter-alpha-inhibitor binding to hyaluronan in the cumulus extracellular matrix is required for optimal ovulation and development of mouse oocytes. Biol Reprod. 1999; 61: 436 - 443.

Hill JL, Wade MG, Nancarrow CD, Kelleher DL, Boland MP. Influence of ovine oviductal amino acid concentrations and ovine oestrus-associated glycoproteinon development and viability of bovine embryos. Mol Reprod Dev. 1997; 47: 164-169.

Hinrichs K, Love CC, Brinsko SP, Choi YH, Varner DD. In vitro fertilization of in vitro-matured equine oocytes: effect of maturation medium, duration of maturation, and sperm calcium ionophore treatment, and comparison with rates of fertilization in vivo after oviductal transfer. Biol Reprod. 2002; 67: 256 - 262.

Hirshfield AN. Development of follicles in the mammalian ovary. Int Rev Cytol. 1991; 124: 43 101.

Ho E. Zinc deficiency, DNA damage and cancer risk. J Nutr Biochem. 2004; 15 (10): 572 - 578.

Ho E, Ames BN. Low intracellular zinc induces oxidative DNA damage, disrupts p53, NFkappaB and AP1 binding and affects DNA repair in a rat glioma cell line. Proc Natl Acad Sci USA. 2002; 99: $16770-16775$.

Ho E, Courtemanche C, Ames BN. Zinc deficiency induces oxidative DNA damage and increases p53 expression in human lung fibroblasts. J Nutr. 2003; 133: 2543 - 2548. 
Ho HC, Suarez SS. Hyperactivation of mammalian spermatozoa: function and Regulation. Reproduction. 2001; 122, 519 - 526.

Holmes RP, Goodman HO, Shihabl ZK, Jarow JP. The Taurine and Hypotaurine Content of Human Semen. Joumal of Andrology. 1992; 13 (3): 289 - 292.

Holt WV, North RD. Thermotropic phase transitions in the plasma membrane of ram spermatozoa. J Reprod Fertil. 1986; 78 (2): 447 - 57.

Høst E, Gabrielsen A, Lindenberg S, Smidt-Jensen S. Apoptosis in human cumulus cells in relation to zona pellucida thickness variation, maturation stage, and cleavage of the corresponding oocyte after intracytoplasmic sperm injection. Fertil Steril. 2002; 77 (3): 511 $-515$.

Hostetler CE, Kincaid RL, Mirando MA. The role of essential trace elements in embryonic and fetal development in livestock. Vet J. 2003; 166: 125 - 139.

Huang Z, Wells D. The human oocyte and cumulus cells relationship: new insights from the cumulus cell transcriptome. Mol Hum Reprod. 2010; 16 (10): 715 - 725.

Hulboy DL, Rudolph LA, Matrisian LM. Matrix metalloproteinases as mediators of reproductive function. Molecular Human Reproduction. 1997; 3 (1): 27 - 45.

Hunter AG, Moor RM. Stage-Dependent Effects of Inhibiting Ribonucleic Acids and Protein Synthesis on Meiotic Maturation of Bovine Oocytes In Vitro. Journal of Dairy Science. 1987; 70 (8): 1646 - 1651.

Hunter RHF. Modulation of gamete progression and maturation in the female genital tract. Mol Reprod Dev. 1994; 39: 176 - 181. 
Ikeda S, Imai H, Yamada M. Apoptosis in cumulus cells during in vitro maturation of bovine cumulus-enclosed oocytes. Reproduction. 2003; 125 (3): 369 - 376.

Iritani A, Niwa K. Capacitation of bull spermatozoa and fertilization in vitro of cattle follicular oocytes matured in culture. J Reprod Fertil. 1977; 50: 119 - 121.

Jackson KA, Valentine RA, Coneyworth LJ, Mathers JC, Ford D. Mechanisms of mammalian zinc-regulated gene expression. Biochem Soc Trans. 2008; 36 (6): 1262 - 1266.

Jessus C, Ozon R. Regulation of cell divisions during oogenesis of vertebrates: the xenopus oocyte paradigm. Comp Biochem Physiol. 1993; 106: 431 - 448.

Jin M, Fujiwara E, Kakiuchi Y, Okabe M, Satouh Y, Baba SA, Chiba K, Hirohashi N. Most fertilizing mouse spermatozoa begin their acrosome reaction before contact with the zona pellucida during in vitro fertilization. Proc Natl Acad Sci. 2011; 108 (12): 4892 - 4896.

Johnson J, Canning J, Kaneko T, Pru JK, Tilly JL. Germline stem cells and follicular renewal in the postnatal mammalian ovary. Nature. 2004; 428: $145-150$.

Jolly PD, Tisdall DJ, Heath DA, Lun S, McNatty KP. Apoptosis in bovine granulosa cells in relation to steroid synthesis, cyclic adenosine 3',5'-monophosphate response to folliclestimulating hormone and luteinizing hormone, and follicular atresia. Biology of Reproduction. 1994; 51: 934 - 944.

Jones KT. Turning it on and off: M-phase promoting factor during meiotic maturation and fertilization. Molecular Human Reproduction. 2004; 10: 1 - 5. 
Josefsberg LB, Galiani D, Dantes A, Amsterda MA, Dekel N. The proteosome is involved in the first metaphase-to-anaphase transition of meiosis in rat oocytes. Biol Reprod. 2000; 62: $1270-1277$.

Kambe T, Weaver BP, Andrews GK. The genetics of essential metal homeostasis during development. Genesis. 2008, 46 (4): 214 - 228.

Kanitz W, Brüssow KP, Becker F, Torner H, Tomek W. Comparative Aspects of Follicular Development, Follicular and Oocyte Maturation and Ovulation in Cattle and Pigs. Arch. Tierz. 2001; 44: 9 - 23.

Katska-Ksiazkiewicz L, Ryñska B, Gajda B, Smorag Z. Effect of donor stimulation, frozen semen and heparin treatment on the efficiency of in vitro embryo production in goats. Theriogenology. 2004; 62: 576 - 586.

Katz DF, Drobnis EZ, Overstreet JW. Factors regulating mammalian sperm migration through the female reproductive tract and oocyte vestments. Gamete Res. 1989; 22 (4): 443 - 69.

Kelly RE, Mally MI, Evans DR. The dihydroorotase domain of the multifunctional protein CAD. Subunit structure, zinc content, and kinetics. J Biol Chem. 1986; 261: 6073 - 6083.

Kessova IG, Ho YS, Thung S, Cederbaum Al. Alcohol-induced liver injury in mice lacking Cu, Zn- superoxide dismutase. Hepatology. 2003; 38: 1136 - 1145.

Kim AM, Bernhardt ML, Kong BY, Ahn RW, Vogt S, Woodruff TK, O'Halloran TV. Zinc sparks are triggered by fertilization and facilitate cell cycle resumption in mammalian eggs. ACS Chem Biol. 2011; 6 (7): 716 - 723. 
Kim AM, Vogt S, O'Halloran TV, Woodruff TK. Zinc availability regulates exit from meiosis in maturing mammalian oocytes. Nat Chem Biol. 2010; 6 (9): 674 - 681.

Kim JH, Niwa K, Lim JM, Okuda K. Effects of Phosphate, Energy Substrates, and Amino Acids on Development of In Vitro-Matured, In Vitro-Fertilized Bovine Oocytes in a Chemically Defined,Protein-Free Culture Medium. Biol. Reprod. 1993; 48: 1320 - 1325.

Kim SK, Minami N, Yamada M, Utsumi K. Functional role of cumulus cells during maturation in development of in vitro matured and fertilized bovine oocytes. Theriogenology. 1996; 45: 278.

Kincaid RL. Assessment of trace mineral status of ruminants: a review. Proc Am Soc Anim Sci. 1999; 1 - 10.

Kincaid RL, Chew BP, Cronrath JD. Zinc oxide and amino acids as sources of dietary zinc for calves: effects on uptake and immunity. J Dairy Sci. 1997; 80 (7): 1381 - 1388.

Kincaid RL, Miller WJ, Fowler PR, Gentry RP, Hampton DL, Neathery MW. Effect of high dietary zinc metabolism and intracellular distribution in cows and calves. J. Dairy Sci. 1976; 59: $1580-1584$.

Kobayashi H, Minshull J, Ford C, Golsteyn R, Poon R, Hunt T. On the synthesis and destruction of A- and B-type cyclins during oogenesis and meiotic maturation in Xenopus laevis. J Cell Biol. 1991; 114: 755 - 765.

Kojima-Yuasa A, Ohkita T, Yukami K, Ichikawa H, Takami N, Nakatani T, Opare Kennedy D, Nishiguchi S, Matsui-Yuasa I. Involvement of intracellular glutathione in zinc deficiencyinduced activation of hepatic stellate cells. Chem Biol Interact. 2003; 146 (1): 89 - 99. 
Kopera IA, Bilinska B, Cheng CY, Mruk DD. Sertoli-germ cell junctions in the testis: a review of recent data. Phil. Trans. R. Soc. B. 2010; 365: 1593 - 1605.

Krezel A, Wojcik J, Maciejczyk M, Bal W. May GSH and L-His contribute to intracellular binding of zinc? Thermodynamic and solution structural study of a ternary complex. Chem Commun. 2003; 6: $704-705$.

Krisher RL. The effect of oocyte quality on development. J. Anim. Sci. 2004; 82 (Suppl. E.): 14 23.

Kumar N, Verma RP, Singh LP, Varshney VP, Dass RS. Effect of different levels and sources of zinc supplementation on quantitative and qualitative semen attributes and serum testosterone level in crossbred cattle (Bos indicus x Bos taurus) bulls. Reprod Nutr Dev. 2006; 6: $663-675$.

Lafleur MVM, Hoorweg JJ, Joenje H, Westmijze EJ, Retel J. The ambivalent role of glutathione in the protection of DNA against single oxygen. Free radical Res. 1994; 21: 9 - 17.

Laity JH, Lee BM, Wright PE. Zinc finger proteins: new insights into structural and functional diversity. Current Opinion in Structural Biology. 2001; 11: 39 - 46.

Lambert RD, Bernard C, Rioux JE, Ealand R, D' Amours D, Montreuil A. Endoscopy in cattle by the paralumbar route: technique for ovarian examination and follicular aspiration. Theriogenology. 1983; 20: 149 - 161.

Lancaster R, Catt J, Rhodes S, Polege C. Bull and breed specific effects of heparin-capacitated bovine sperm on in vitro of in vitro maturated follicular oocytes. Proceedings of the Six European Congress of the Embrio Transfer Association (Lyon), Francia, 1990, p. 166. 
Larsen W, Wert S, Brunner G. A dramatic loss of cumulus cell gap junctions is correlated with germinal vesicle breakdown in rat oocytes. Dev Biol. 1986; 113: 517 - 521.

Larsen WJ. Mechanisms of gap junction modulation. En: Sperelakis N, Cole WC (eds.), Cell Interactions and Gap Junctions. Vol. I. Boca Raton, FL: CRC Press, 1989, p. 3 - 27.

Larsen WJ, Chen L, Powers R, Zhang H, Russell PT, Chambers C, Hess K, Flick R. Cumulus expansion initiates physical and developmental autonomy of the oocyte. Zygote. 1996; 4: $335-341$.

Larsen WJ, Wert SE. Role of cell junctions in gametogenesis and in early embryonic development. Tissue \& Cell. 1988; 20: 809 - 848.

Lawrance T, Beers W, Gilula N. Transmission of hormonal stimulation by cell-to-cell communication. Nature. 1978; 272: 501 - 506.

Li L, Zheng P, Dean J. Maternal control of early mouse development. Development. 2010; 137: $859-870$.

Li X, Morris LH, Allen WR. Influence of co-culture during maturation on the developmental potential of equine oocytes fertilized by intracytoplasmic sperm injection (ICSI). Reproduction. 2001; 121: 925 - 932.

Lichten LA, Cousins RJ. Mammalian Zinc Transporters: Nutritional and Physiologic Regulation. Annu. Rev. Nutr. 2009; 29:153 - 76.

Liu K, Rajareddy S, Liu L, Jagarlamudi K, Boman K, Selstam G, Reddy P. Control of mammalian oocyte growth and early follicular development by the oocyte PI3 kinase pathway: New roles for an old timer. Developmental Biology. 2006; 299: 1 - 11. 
Lodde V, Modina S, Galbusera C, Franciosi F, Luciano AM. Large-scale chromatin remodeling in germinal vesicle bovine oocytes: interplay with gap junction functionality and developmental competence. Molecular Reproduction and Development. 2007; 74: 740 749.

Lonergan P, Monaghan P, Rizos D, Boland MP, Gordon I. Effect of follicle size on bovine oocyte quality and developmental competence following maturation, fertilization, and culture in vitro. Mol. Reprod. Dev. 1994; 37: 48 - 53.

Lopes AS, Lane M, Thompson JG. Oxygen consumption and ROS production are increased at the time of fertilization and cell cleavage in bovine zygotes. Hum Reprod. 2010; 25 (11): $2762-2773$.

Lu KH, Gordon I, Chen HB, McGovern H. In vitro culture of early bovine embryos derived from in vitro fertilization of follicular oocytes matured in vitro. Proceedings of the Third Scientific Meeting of the European Embryo Transfer association (Lyon), Francia, 1987, p. 70.

Luberda Z. The role of glutathione in mammalian gametes. Reprod Biol. 2005; 5 (1): 5 - 17.

Luciano AM, Lodde V, Beretta MS, Colleoni S, Lauria A, Modina S. Developmental capability of denuded bovine oocyte in co-culture system with intact cumulus-oocyte complexes: role of cumulus cells, cyclic adenosine 30,50-monophosphate, and glutathione. Mol Reprod and Devel. 2005; 71: $389-397$.

Luciano AM, Modina S, Gandolfi F, Lauria A and Armstrong DT. Effect of cell-to-cell contact on in vitro deoxyribonucleic acid synthesis and apoptosis responses of bovine granulosa cells to insulin-like growth factor-I and epidermal growth factor. Biology of Reproduction. 2000; 63: $1580-1585$. 
Madison V, Avery B, Greve T. Selection of immature bovine oocytes for developmental potential in vitro. Anim. Reprod. Sci. 1992; 27: 1 - 11.

Maedomari N, Kikuchi K, Ozawa M, Noguchi J, Kaneko H, Ohnuma K, Nakai M, Shino M, Nagai T, Kashiwazaki N. Cytoplasmic glutathione regulated by cumulus cells during porcine oocyte maturation affects fertilization and embryonic development in vitro. Theriogenology. 2007; 67: $983-993$.

Mafra D, Cozzolino SMF. The importance of zinc in human nutrition. Rev. Nutr. 2004; 17 (1): 79 $-87$.

Mahi CA, Yanagimachi R. The effects of temperature, osmolality and hydrogen ion concentration on the activation and acrosome reaction of golden hamster spermatozoa. J Reprod Fertil. 1973; 35 (1): 55 - 66.

Malcolm-Callis KJ, Duff GC, Gunter SA, Kegley EB, Vermeire DA. Effects of supplemental zinc concentration and source on performance, carcass characteristics, and serum values in finishing beef steers. J Anim Sci. 2000; 78 (11): 2801 - 2808.

Manabe N, Imai Y, Ohno H, Takahagi Y, Sugimoto $M$ and Miyamoto H. Apoptosis occurs in granulosa cells but not cumulus cells in the atretic antral follicles in pig ovaries. Experientia. 1996; 52: 647 - 651.

Mao J, Wu G, Smith MF, McCauley TC, Cantley TC, Prather RS, Didion BA, Day BN. Effects of culture medium, serum type, and various concentrations of follicle-stimulating hormone on porcine preantral follicular development and antrum formation in vitro. Biol Reprod. 2002; 67: $1197-1203$. 
Mapletoft RJ, Hasler JF. Assisted reproductive technologies in cattle: a review. Rev Sci Tech. 2005; 24 (1): $393-403$.

Maret $\mathrm{W}$. Oxidative metal release from metallothionein via zinc-thiol/disulfide interchange (metafloproteins/glutathione/ metal clusters/radiochromatography). Proc Natl Acad Sci USA. 1994; 91: $237-241$.

Maret W. The Function of Zinc Metallothionein: A Link between Cellular Zinc and Redox State. American Society for Nutritional Sciences. 2000; 130 (5S Suppl):1455 - 1458.

Maret W. Cellular Zinc and Redox States Converge in the Metallothionein/Thionein Pair. American Society for Nutritional Sciences. 2003; 133 (5 Suppl 1): 1460 - 1462.

Marklund SL, Andersen PM, Forsgren L, Nilsson P, Ohlsson PI, Wikander G, Oberg A. Normal binding and reactivity of copper in mutant superoxide dismutase isolated from amyotrophic lateral sclerosis patients. J Neurochem. 1997; 69 (2): 675 - 681.

Marquez B, Suarez SS. Bovine sperm hyperactivation is promoted by alkaline-stimulated Ca2+ influx. Biol Reprod. 2007; 76 (4): 660 - 665.

Márquez S, Valenzuela Pérez L, Ifrán SD, Pinto ME. Citoesqueleto. www.genomasur.com/lecturas/Guia06.htm. Disponible en la web el 24 de Agosto de 2011.

Martin SJ, Mazdai G, Strain JJ, Cotter TG, Hannigan BM. Programmed cell death (apoptosis) in lymphoid and myeloid cell lines during zinc deficiency. Clin. Exp. Immunol. 1991; 83: 338 343.

Martínez E, Ruiz S, Roca J, Vázquez JM. Fecundación in vitro en los animales de granja. Ed: Secretariado de Publicaciones de la Universidad de Murcia. Murcia, España, 1989. 
Martínez Madrid B. Estudio de la fecundación "in vitro" en porcino: reducción de la poliespermia y optimización de la producción "in vitro" de embriones. Tesis doctoral. Facultad de Veterinaria. Universidad Complutense de Madrid. 2002

Martinvalet D, Zhu P, Lieberman J. Granzyme A induces caspase-independent mitochondrial damage, a required first step for apoptosis. Immunity. 2005; 22 (3): 355 - 370.

Masui Y. A quest for cytoplasmic factors that control the cell cycle. Prog Cell Cycle Res. 1996, 2 : $1-13$.

Masui $\mathrm{Y}$. From oocyte maturation to the in vitro cell cycle: the history of discoveries of Maturation-Promoting Factor (MPF) and Cytostatic Factor (CSF). Differentiation. 2001; 69: $1-17$.

Masui Y, Clark H. Regulation of oocyte maturation. Int Rev Cytol. 1979; 57: 185 - 282.

Masuri Y, Market CL. Cytoplasmic control of nuclear behaviour during meiotic maturation of frog oocytes. J Exp Zool. 1971; 177 (2): 129 - 145.

Mattioli M, Bacci ML, Galeati G, Seren E. Developmental competence of pig oocytes matured and fertilized in vitro. Theriogenology. 1989; 31: 1201 - 1207.

Mattson BA, Albertini DF. Oogenesis: Chromatin and microtubule dynamics during meiotic prophase. Mol Reprod Dev. 1990; 25: 374 - 384.

Matzuk MM, Burns KH, Viveiros MM, Eppig JJ. Intercellular communication in the mammalian ovary: oocytes carry the conversation. Science. 2002; 296: $2178-2180$.

Matzuk MM, Dionne L, Guo Q, Kumar TR, Lebovitz RM. Ovarian function in superoxide dismutase 1 and 2 knockout mice. Endocrinology. 1998; 139: 4008 - 4011. 
Mauleon P. Cinétique de I’ovogeenèse chez les mammifères. Arch Anat Micros Morphol Exp. 1967; 56: 125 - 150.

McCall KA, Huang CC, Fierke CA. Function and Mechanism of Zinc Metalloenzymes. J. Nutr. 2000; 130: 1437 - 1446.

McGhee EA, Hsueh AJ. Initial and cyclic recruitment of ovarian follicles. Endocr Rev. 2000; 21 : $200-214$.

McMahon RJ, Cousins RJ. Regulation of the zinc transporter ZnT-1 by dietary zinc. Proc. Natl. Acad. Sci. USA. 1998; 95 (9): 4841 - 4846.

McNatty KP, Smith P, Hudson NL, Heath DA, Tisdall DJ, O WS, Braw-Tal R. Development of the sheep ovary during fetal and early neonatal life and the effect of fecundity genes. J Reprod Fertil. 1995; 49: $123-135$.

McPartlin LA, Suarez SS, Czaya CA, Hinrichs K, Bedford-Guaus SJ. Hyperactivation of stallion sperm is required for successful in vitro fertilization of equine oocytes. Biol Reprod. 2009; 81 (1): 199 - 206.

Meduri G, Charnaux N, Driancourt MA, Combettes L, Granet P, Vannier B, Loosfelt H, Milgrom E. Follicle-stimulating hormone receptors in oocytes? J Clin Endocrinol Metab. 2002; 97: $2266-2276$.

Meister A. Glutathione Metabolism and Its Selective Modification. The Journal of Biological Chemistry. 1988; 25: 17205 - 17208.

Meizel S. Molecules that initiate or help stimulate the acrosome reaction by their interaction with the mammalian sperm surface. Am J Anat. 1985; 174: 285 - 302. 
Ménézo Y, Pluntz L, Chouteau J, Gurgan T, Demirol A, Dalleac A, Benkhalifa M. Zinc concentrations in serum and follicular fluid during ovarian stimulation and expression of Zn2+ transporters in human oocytes and cumulus cells. Reprod Biomed Online. 2011; 22 (6): 647-652.

Merton JS, Ask B, Onkundi DC, Mullaart E, Colenbrander B, Nielen M. Genetic parameters for oocyte number and embryo production within a bovine ovum pick-up-in vitro production embryo-production program. Theriogenology. 2009; 72 (7): 885-893.

Miao L, St Clair DK. Regulation of superoxide dismutase genes: implications in disease. Free Radic Biol Med. 2009; 47(4): 344 - 56.

Miller WJ. Absorption, Tissue Distribution, Endogenous Excretion, and Homeostatic Control of Zinc in Ruminants. The American journal of clinical nutrition. 1969; 22 (10): 1323 - 1331.

Miller WJ, Blackmon DM, Gentry RP, Pate FM. Zinc absorption, metabolism, and endogenous excretion in zinc-deficient and normal calves over an extended time. J Dairy Sci. 1991; 74 (10): 3535 - 3543.

Miller WJ, Stake PE. Use and limitations of biochemical measurements in diagnosing mineral deficiencies. Ga. Nutr. Conf. Feed Ind. 1974, p. 25.

Minami N, Suzuki T, Tsukamoto S. Zygotic gene activation and maternal factors in mammals. J. Reprod. Dev. 2007; 53: 707 - 715.

Modina S, Luciano AM, Vassena R, Baraldi-Scesi L, Lauria A, Gandolfi F. Oocyte developmental competence after in vitro maturation depends on the persistence of cumulus-oocyte communications which are linked to the intracellular concentration of cAMP. Italian Journal of Anatomy and Embryology. 2001; 106: 241 - 248. 
Moniruzzaman M, Miyano T. Growth of Primordial Oocytes in Neonatal and Adult Mammals. J Reprod. Dev. 2010; 56: 559 - 566.

Moor R, Hutching A, Hawkins C, Jung T. Towards a molecular understanding of meiosis in domestic animals. En: Lauria A, Gandolfi F (Eds) Embrionic Development and Manipulation in Animal Production. Portland Press, London and Chapel Hill, 1992, p. 38 45.

Moor RM, Dai Y, Lee C, Fulka J Jr. Oocyte maturation and embryonic failure. Hum Reprod Update. 1998; 4 (3): 223 - 236.

Moor RM, Smith MW, Dawson MC. Measurement of intercellular coupling between oocytes and cumulus cells using intracellular markers. Exp Cell Res. 1980; 126: 15 - 29.

Moor RM, Trounson AO. Hormonal and follicular factors affecting maturation of sheep oocytes in vitro and their subsequent developmental capacity. J. Reprod. Fert. 1977; 49: 101- 109.

Mori T, Amano T, Shimizu H. Roles of gap junctional communication of cumulus cells in cytoplasmic maturation of porcine oocytes cultured in vitro. Biol Reprod. 2000; 62: 913 919.

Mugnier S, Kervella M, Douet C, Canepa S, Pascal G, Deleuze S, Duchamp G, Monget P, Goudet G. The secretions of oviduct epithelial cells increase the equine in vitro fertilization rate: are osteopontin, atrial natriuretic peptide $A$ and oviductin involved?. Reprod Biol Endocrinol. 2009; 7: 129.

Nagai T, Funahashi H, Yoshioka K, Kikuchi K. Up date of in vitro production of porcine embryos. Front Biosci. 2006; 11: 2565 - 2573. 
Nagyova E, Scsukova S, Nemcova L, Mlynarcikova A, Yi YJ, Sutovsky M, Sutovsky P. Inhibition of proteasomal proteolysis affects expression of extracellular matrix components and steroidogenesis in porcine oocyte-cumulus complexes. Domest Anim Endocrinol. 2012; 42 (1): $50-62$.

National Research Council (NRC). Nutrient Requirements of Beef Cattle. 7ma edición. National Academy Press, Washington, DC, USA, 2000.

Neathery MW, Miller WP, Blackmon DM, Gentry RP, Jones JB. Absorption and tissue zinc content in lactating dairy cows as affected by low dietary zinc. J Anim Sci. 1973; 37 (3): $848-852$.

Nemcová L, Nagyová E, Petlach M, Tománek M, Procházka R. Molecular mechanisms of insulin-like growth factor 1 promoted synthesis and retention of hyaluronic acid in porcine oocyte-cumulus complexes. Biol Reprod. 2007; 76 (6): 1016 - 1024.

Nockels CF, DeBonis J, Torrent J. Stress induction affects copper and zinc balance in calves fed organic and inorganic copper and zinc sources. J Anim Sci. 1993; 71 (9): 2539 - 2545.

Nomizu T, Falchuk KH, Vallee BL. Zinc, iron, and copper contents of Xenopus laevis oocytes and embryos. Mol Reprod Dev. 1993; 36: 419 - 423.

Norbury CJ, Zhivotovsky B. DNA damage-induced apoptosis. Oncogene. 2004, 23 (16): 2797 2808.

Novak S, Almeida FRC, Cosgrove JR, Dixon WT, Foxcroft GR. Effect of pre- and postmating nutritional manipulation on plasma progesterone, blastocyst development, and the oviductal environment during early pregnancy in gilts. J Anim Sci. 2003; 81: 772 - 783. 
Nunnery GA, Vasconcelos JT, Parsons CH, Salyer GB, Defoor PJ, Valdez FR, Galyean ML. Effects of source of supplemental zinc on performance and humoral immunity in beef heifers. J. Anim Sci. 2007; 85: 2304 - 2313.

O'Halloran TV. Transitions metals in control of gene expression.Science. 1993; 261: 715 - 725.

Olin KL, Shigenaga MK, Ames BN, Golub MS, Gershwin ME, Hendrickx AG. Maternal dietary zinc influences DNA strand break and 8-hydroxy-2V-deoxyguanosine levels in infant rhesus monkey liver. Proc Soc Exp Biol Med. 1993; 203: 461 - 466.

Olive PL, Durand RE, Jackson SM, Le Riche JC, Luo C, Ma R, McLaren DB, Aquino-Parsons C, Thomson TA, Trotter T. The comet assay in clinical practice. Acta Oncol. 1999; 8: 839 844.

Olive PL, Durand RE, Le Richen J, Olivotto IA, Jackson SM. Gel electrophoresis of individual cells to quantify hypoxic fraction in human breast cancers. Cancer Res. 1993; 53: 733 736.

Oteiza PI, Clegg MS, Zago MP, Keen CL. Zinc deficiency induces oxidative stress and AP-1 activation in 3T3 cells. Free Radic Biol Med. 2000; 28: 1091 - 1099.

Oteiza PI, Olin KL, Fraga CG, Keen CL. Zinc deficiency causes oxidative damage to proteins, lipids and DNA in rat testes. J Nutr. 1995; 125 (4): 823 - 829.

Otero RM. Evaluación de la motilidad y viabilidad del semen bovino mediante el uso de sistema casa y citometría de flujo: identificación de subpoblaciones espermáticas. Tesis doctoral. Facultad de veterinaria, Universidad de Santiago de Compostela. 2008. 
Paasch U, Sharma RK, Gupta AK, Grunewald S, Mascha EJ, Thomas AJ Jr, Glander HJ, Agarwal A. Cryopreservation and thawing is associated with varying extent of activation of apoptotic machinery in subsets of ejaculated human spermatozoa. Biology of Reproduction. 2004; 71: 1828 - 1837.

Palma GA. Fisiología del ciclo estral bovino. En: Palma GA Biotecnología de la reproducción. Primera edición. Argentina, 2001a, p 37 - 49.

Palma GA. Producción in vitro de embriones bovinos. En: Palma GA Biotecnología de la reproducción. Primera edición. Argentina, 2001b, p. 246 - 247.

Palmer E, Bezard J, Magistrini M, Duchamp G. In vitro fertilization in the horse: a retrospective study. Proceeding of the Fifth International Symposium on Equine Reproduction. Deauville, 1990, 124 - 125.

Palmer E, Bezard J, Magistrini M, Duchamp G. In vitro fertilization in the horse: a retrospective study. J Reprod Fertil. 1991; 44: 375 - 384.

Pangas SA, Matzuk MM. The art and artifact of GDF9 activity: cumulus expansion and the cumulus expansion-enabling factor. Biologyof Reproduction. 2005; 73: 582 - 585.

Parrish JJ, Parrish JL, First NL. Effect of swim-up separation and heparin pretreatment of frozenthawed spermatozoa on in vitro fertilization of bovine oocytes. Biol Reprod. 1984; 30 (1): 112.

Parrish JJ, Susko-Parrish JL, First NL. Role of heparine in bovine sperm capacitation. Biol Reprod. 1985a; 32 (1): 211. 
Parrish JJ, Susko-Parrish JL, First NL. In vitro fertilization of bovine oocytes using heparine treated and swim-up separated frozen-thawed bovine semen is repeatable and results in high frequencies of fertilization. Theriogenology. 1985b; 23: 216.

Parrish JJ, Susko-Parrish JL, Leibfried-Rutledge ML, Critser ES, Eyestone WH, First NF. Bovine in vitro fertilization with frozen thawed semen. Theriogenology. 1986; 25: 591 - 600.

Parrish JJ, Susko-Parrish JL, Winer MA, First NL. Capacitation of bovine sperm by heparin. Biol Reprod. 1988; 38: 1171 - 1180.

Paules R, Buccione R, Moschel R, Vande Woude G, Eppig J. Mouse Mos protooncogene product is present and functions during oogenesis. Proc Natl Acad Sci USA. 1989; 86: $5395-5399$.

Paulsen IT, Saier Jr MH. A novel family of ubiquitous heavymetal ion transport proteins. J Membr Biol. 1997; 156: 99 - 103.

Paynton B, Rempel R, Bachvarova R. Changes in state of adenylation and time course of degradation of maternal mRNAs during oocyte maturation and early embryonic development in the mouse. Dev. Biol. 1988; 129: 304 - 314.

Pedersen T, Peters H. Proposal for the classification of oocytes and follicles in the mouse ovary. J Reprod Fertil. 1968; 17: 555 - 557.

Peres A. The calcium current of mouse egg measured in physiological calcium and temperature conditions. J. Physiol. 1987; 391: 573 - 588. 
Perreault SD, Barbee RR, Slott VL. Importance of glutathione in the acquisition and maintenance of sperm nuclear decondensing activity in maturing hamster oocytes. Dev Biol. 1988; 125: $181-186$.

Perry ACF, Verlhac MH. Second meiotic arrest and exit in frogs and mice. EMBO Rep. 2009; 3: $246-251$.

Perry DK, Smyth MJ, Stennicke HR, Salvesen GS, Duriez P, Poirier GG, Hannun YA. Zinc is a potent inhibitor of the apoptotic protease, caspase-3. A novel target for zinc in the inhibition of apoptosis. J Biol Chem. 1997; 272 (30): 18530 - 18533.

Perry GA, Perry BL. Effect of the timing of controlled internal drug-releasing device insertion on the gonadotropin-releasing hormone-induced luteinizing hormone surge and ovulatory response. J Anim Sci. 2009; 87 (12): 3983 - 3990.

Peter M. In vitro disassembly of the nuclear lamina and M phase specific phosphorilationof lamins by cdc2 kinase. Cell. 1990; 61: 591 - 602.

Peters JM, Wiley LM, Zidenberg-Cherr S, Keen CL. Influence of short-term maternal zinc deficiency on the in vitro development of preimplantation mouse embryos. Proc Soc Exp Biol Med. 1991; 198 (1): 561 - 568.

Petrunkina AM, Waberski D, Günzel-Apel AR, Töpfer-Petersen E. Determinants of sperm quality and fertility in domestic species. Reproduction. 2007; 134 (1): 3 - 17.

Phelps E, Wu P, Bretz JR. Thyroid cell apoptosis. A new understanding of thyroid autoimmunity. End \& Met Clin. N.A. 2000; 29 (2): 375 - 388. 
Phillips BT, Gassei K, Orwig KE. Spermatogonial stem cell regulation and spermatogenesis. Phil. Trans. R. Soc. B. 2010; 365: 1663 - 1678.

Pias EK, Ekshyyan OY, Rhoads CA, Fuseler J, Harrison L, Aw TY. Differential effects of superoxide dismutase isoform expression on hydroperoxide-induced apoptosis in PC-12 cells. J Biol Chem. 2003; 278 (15): 13294 - 13301.

Pieterse MC, Kappen KA, Kruip ThAM, Taverne MAM. Aspiration of bovine oocytes during transvaginal ultrasound scanning of the ovaries. Theriogenology. 1988; 30: 751 - 762.

Pincus G. The eggs of mammals. Mc Millan (Ed). New York Press, New York, 1936.

Pincus G, Enzmann E. The comparative behavior of mammalian eggs in vivo and in vitro I. The activation of ovarian eggs. J Exp Med. 1935; 62: 665 - 675.

Pincus G, Saunders B. The comparative behavior of mammalian eggs in vivo and in vitro VI. The maturation of human ovarian ova. Anat Rec. 1939; 75: 737 - 741.

Polavarapu R, Spitz DR, Sim JE, Follansbee MH, Oberley LW, Rahemtulla A, Nanji AA. Increased lipid peroxidation and impaired antioxidant enzyme function is associated with pathological liver injury in experimental alcoholic liver disease in rats fed diets high in corn oil and fish oil. Hepatology. 1998; 27: 1317 - 1323.

Poul JM, Hue S, Godard T, Sanders P. Lack of genotoxicity of potassium iodate in the alkaline comet assay and in the cytokinesis-block micronucleus test. Comparison to potassium bromate. Food Chem. Toxicol. 2004; 42: 209 - 215.

Powell SR. The antioxidant properties of zinc. J Nutr. 2000; 130: $1447-1454$. 
Prasad AS. Zinc deficiency in humans: a neglected problem. J Am Coll Nutr. 1998; 17: 542 543.

Prasad AS. Zinc deficiency. BMJ. 2003; 326: 409 - 410.

Prasad AS, Kucuk O. Zinc in cancer prevention. Cancer Metastasis Rev. 2002; 21: 291 - 295.

Quirk SM, Harman RM and Cowan RG. Regulation of Fas antigen (Fas, CD95)-mediated apoptosis of bovine granulosa cells by serum and growth factors. Biology of Reproduction. 2000; 63: $1278-1284$.

Racowsky C. Effect of forskolin on maintenance of meiotic arrest and stimulation of cumulus expansion, progesterone and cyclic AMP production by pig oocyte-cumulus complexes. J. Reprod. Fertil. 1985; 74: 9 - 21.

Racowsky C, Satterlie RA. Metabolic, fluorescent dye and electrical coupling between hamster oocytes and cumulus cells during meiotic maturation in vivo and in vitro. Dev. Biol. 1985; 108: $191-202$.

Rahman I, Bel A, Mulier B, Lawson MF, Harrison DJ, MacNee W, Smith CAD. Transcriptional regulation of $\gamma$-glutamilcysteine synthetase-heavy subunit by oxidants in human alveolar epithelial cells. Biochem Biophys Res Commun. 1996; 229: 832 - 837.

Rana SVS. Metals and apoptosis: Recent developments. Journal of Trace Elements in Medicine and Biology. 2008; 22: $262-284$.

Reaume AG, Elliott JL, Hoffman EK, Kowall NW, Ferrante RJ, Siwek DF, Wilcox HM, Flood DG, Beal MF, Brown RH Jr. Scott RW, Snider WD. Motor neurons in Cu/Zn superoxide 
dismutase deficient mice develop normally but exhibit enhanced cell death after axonal injury. Nat. Genet. 1996; 13: $43-47$.

Richards JS. Hormonal control of ovarian follicular development. Rec Prog Horm Res. 1979; 35 : $343-373$.

Richards JS, Russel DL, Ochsner S, Hsieh M, Doyle KH, Falender AE, Lo YK, Sharma SC. Novel signaling pathways that control ovarian follicular development, ovulation and luteinization. Recent Prog Horm Res. 2002; 57: 195 - 220.

Rieger D, Loskutoff NM. Changes in the metabolism of glucose, pyruvate, glutamine and glycine during maturation of cattle oocytes in vitro. Journal Reprod. Fert. 1994; 100: 257 - 262.

Rienzi L, Vajta G, Ubaldi F. Predictive value of oocyte morphology in human IVF: a systematic review of the literature. Hum Reprod Update. 2011; 17 (1): 34 - 45.

Riggio M, Filosa S, Parisi E, Scudiero R. Changes in zinc, copper and metallothionein contents during oocyte growth and early development of the teleost Danio rerio (zebrafish). Comp Biochem Physiol C Toxicol Pharmacol. 2003; 135 (2): 191-196.

Robaire B, Hinton BT, Orgebin-Crist MC. En: Knobil E. Neill JD (Eds) The Physiology of Reproduction. Elsevier/Academic Press, Amsterdam, Boston, 2006, p. 1071 - 1149.

Roberts BR, Tainer JA, Getzoff ED, Malencik DA, Anderson SR, Bomben VC, Meyers KR, Karplus PA, Beckman JS. Structural characterization of zinc-deficient human superoxide dismutase and implications for ALS. J Mol Biol. 2007; 373 (4): 877 - 890. 
Romar Andrés R. Efecto de las células oviductales y del cumulus oophorus sobre diferentes parámetros biológicos relacionados con la fecundación in vitro en la especie porcina. Tesis doctoral. Facultad de Veterinaria. Universidad de Murcia. 2001.

Rosa DE, Fazzio LE, Picco SJ, Furnus CC, Mattioli GA. Metabolismo y deficiencia de zinc en bovinos. Analecta Veterinaria. 2008; 28 (2): $34-44$.

Rosati F, Capone A, Giovampaola CD, Brettoni C, Focarelli R. Sperm-egg interaction at fertilization: glycans as recognition signals. Int. J. Dev. Biol. 2000; 44: 609 - 618 .

Rose TA, Bavister BD. Effect of oocyte maturation medium on in vitro development of in vitro fertilized bovine embryos. Mol Reprod Dev. 1992; 31: 72 - 77.

Sahawneh MA, Ricart KC, Roberts BR, Bomben VC, Basso M, Ye Y, Sahawneh J, Franco MC, Beckman JS, Estévez AG. Cu,Zn-superoxide dismutase increases toxicity of mutant and zinc-deficient superoxide dismutase by enhancing protein stability. J Biol Chem. 2010; 285 (44): 33885 - 33897.

Sakaguchi S, lizuka Y, Furusawa S, Ishikawa M, Satoh S, Takayanagi M. Role of $\mathrm{Zn}(2+)$ in oxidative stress caused by endotoxin challenge. Eur J Pharmacol. 2002; 451: $309-316$.

Salicioni AM, Platt MD, Wertheimer EV, Arcelay E, Allaire A, Sosnik J, Visconti PE. Signalling pathways involved in sperm capacitation. Spermatology. SRF Vol. 65. Roldan ERS and Gomendio M (eds) Nottingham University Press, Nottingham, 2007.

Salustri A, Siracusa G. Metabolic coupling, cumulus expansion and meiotic resumption in mouse cumuli oophori cultured in vitro in the presence of FSH or dcAMP, or stimulated in vivo by hCG. J. Reprod. Fertil. 1983; 68: 335 - 341. 
Salustri A, Yanagishita M, Hascall VC. Synthesis and accumulation of hyaluronic acid and proteoglycans in the mouse cumulus cell-oocyte complex during follicle-stimulating hormone-induced mucification. J Biol Chem. 1989; 264: 13840 - 13847.

Sandstrom B, Cederblad A. Zinc absorption from composite meals. II. Influence of the main protein source, American Journal of Clinical Nutrition. 1980; 33: 1778 - 1783.

Sato E, Miyamoto H, Koide SS. Glycosaminoglycans in porcine folicular fluid promoting viability of oocytes in culture. Mol Reprod Dev. 1990; 26: 391 - 397.

Sawai K, Funahashi H, Niwa K. Stage-specific requirement of cysteine during in vitro maturation of porcine oocytes for glutathione synthesis associated with male pronuclear formation. Biology of Reproduction. 1997; 57: $1-6$.

Sawyer HT, Smith P, Heath DA, Juengel JL, Wakefield SJ, McNatty KP. Formation of ovarian follicles during fetal development in sheep. Biol Reprod. 2002; 66: $1134-1150$.

Scarchilli L, Camaioni A, Bottazzi B, Negri V, Doni A, Deban L, Bastone A, Salvatori G, Mantovani A, Siracusa G, Salustri A. PTX3 interacts with inter-alpha-trypsin inhibitor: implications for hyaluronan organization and cumulus oophorus expansion. J Biol Chem. 2007; 282 (41): 30161 - 30170.

Schatten H, Constantinescu GM. Comparative Reproductive Biology. Blackwell Publishing Professional. Oxford, UK, 2008, p. 61 - 111.

Schrantz N, Blanchard DA, Mitenne F, Auffredou MT, Vazquez A, Leca G. Manganese induces apoptosis of human B cells: caspase-dependent cell death blocked by Bcl-2.Cell Death and Differentiation. 1999; 6: 445 - 453. 
Schroeder AC, Eppig JJ. The developmental capacity of mouse oocytes that matured spontaneously in vitro is normal. Developmental Biology. 1984; 102: 493 - 497.

Schultz R, MontgomeryR, Belanoff J. Regulation of mouse oocyte meiotic maturation: Implication of a decrease in oocyte cAMP and protein dephosphorylation in commitment to resume meiosis. Dev Biol. 1983; 97: 264 - 273.

Seino T, Saito H, Kaneko T, Takahashi T, Kawachiya S, Kurachi H. Eight-hydroxy-2'deoxyguanosine in granulosa cells is correlated with the quality of oocytes and embryos in an in vitro fertilization-embryo transfer program. Fertil Steril. 2002; 77 (6): 1184 - 1190.

Senger PL. Pathways to pregnancy and parturition. $2^{\text {nd }}$ Revised Edition, P. L. Senger, (ed). Cadmus Professional Communications, Ephrata, PA, 2005, p. 44.

Shabankareh HK, Zandi M. Developmental potential of sheep oocytes cultured in different maturation media: effects of epidermal growth factor, insulin-like growth factor I, and cysteamine. Fertil Steril. 2010; 94 (1): 335 - 340.

Shaha C, Tripathi R, Mishra DP. Male germ cell apoptosis: regulation and biology. Phil. Trans. R. Soc. B. 2010; 365: $1501-1515$.

Shankar AH, Prasad AS. Zinc and immune function: the biological basis of altered resistance to infection Am J Clin Nutr. 1998; 68: 447 - 463.

Shi L, Wu J. Epigenetic regulation in mammalian preimplantation embryo development. Reproductive Biology and Endocrinology. 2009; 7: 59. 
Shioya Y, Kuwayama M, Fukushima M, Iwasaki S. In vitro fertilization and cleavage capability of bovine follicular oocytes classified by cumulus cells and matured in vitro. Theriogenology. 1988; 30: 489 - 496.

Sies H. Glutathione and its role in cellular functions. Free Radic Biol Med. 1999; 27: 916 -921.

Silberstein T, Saphier O, Paz-Tal O, Gonzalez L, Keefe DL, Trimarchi JR. Trace element concentrations in follicular fluid of small follicles differ from those in blood serum, and may represent long-term exposure. Fertil Steril. 2009; (5): 1771 - 1774.

Singh B, Meng L, Rutledge JM, Armstrong DT. Effects of epidermal growth factor and folliclestimulating hormone during in vitro maturation on cytoplasmic maturation of porcine oocytes. Mol. Reprod. Dev. 1997; 46: 401 - 407.

Singh NP, McCoy MT, Tice RR, Schneider EL. A simple technique for quantitation of low levels of DNA damage in individual cells. Exp Cell Res. 1988; 175: 184 - 191.

Slavik T, Fulka J. Pregnancies after transfer of sheep embryos produced from oocytes matured and fertilized in vitro. Folia Biologica-Praha. 1991; 37: 94 - 100.

Slavik T, Fulka J. In vitro fertilization of intact sheep and cattle oocyte with goat spermatozoa. Theriogenology. 1992; 38: 721 - 726.

Somfai T, Ozawa M, Noguchi J, Kaneko H, Karja NW, Fahrudin M, Nakai M, Maedomari N, Dinnyés A, Nagai T, Kikuchi K. In vitro development of polyspermic porcine oocytes: Relationship between early fragmentation and excessive number of penetrating spermatozoa. Anim Reprod Sci. 2008; 107(1-2): 131 - 147. 
Song Y, Leonard SW, Traber MG, Ho E. Zinc deficiency affects DNA damage, oxidative stress, antioxidant defenses, and DNA repair in rats. J Nutr. 2009; 139 (9): 1626 -1631.

Sorensen $\mathrm{H}$, Wassarman $\mathrm{P}$. Relationship between growth and meiotic maturation of the mouse oocytes. Dev Biol. 1976; 50: 531 - 536.

Spears JW. Trace mineral bioavailability in ruminants. J Nutr. 2003; 133 (5): 1506 - 1509.

Spears JW, Kegley EB. Effect of zinc source (zinc oxide vs zinc proteinate) and level on performance, carcass characteristics, and immune response of growing and finishing steers. J Anim Sci. 2002; 80 (10): 2747 - 2752.

Speed R. Meiosis in the foetal mouse ovary. I. An analysis at the light microscope level using surface-spreading. Chromosoma. 1982; 85: 427 - 437.

Sreenan JM. In vitro maturation and attempted fertilization of cattle follicular oocytes. J Agric Sci (Cambridge). 1970; 75: 393 - 396.

Srivastava S, Chandrasekar B, Gu Y, Luo J, Hamid T, Hill BG, Prabhu SD. Downregulation of CuZn-superoxide dismutase contributes to beta-adrenergic receptor-mediated oxidative stress in the heart. Cardiovasc Res. 2007; 74 (3): 445 - 455.

Stephenson JL, Brackett BG. Influences of Zinc on fertilization and development of bovine oocytes in vitro. Zygote. 1999; 7: $195-201$.

Stott D, Wylie CC. Invasive behavior of mouse primordial germinal cells in vitro. J Cell Sci. 1986; 86: 133 - 144.

Suarez SS. Control of hyperactivation in sperm. Human Reproduction Update. 2008; 14 (6): 647 $-657$. 
Suarez SS, Dai XB, DeMott RP, Redfern K, Mirando MA. Movement characteristics of boar sperm obtained from the oviduct or hyperactivated in vitro. J Androl. 1992; 13 (1): 75 - 80.

Suarez SS, Katz DF, Owen DH, Andrew JB, Powell RL. Evidence for the function of hyperactivated motility in sperm. Biol Reprod. 1991; 44 (2): 375 - 381.

Sun F, Bahat A, Gakamsky A, Girsh E, Katz N, Giojalas LC, Tur-Kaspa I, Eisenbach M. Human sperm chemotaxis: Both the oocyte and its surrounding cumulus cells secrete sperm chemoattractants. Hum. Reprod. 2005; 20: 761 - 67.

Sun L, Chai Y, Hannigan R, Bhogaraju VK, Machaca K. Zinc regulates the ability of Cdc25C to activate MPF/cdk1. J Cell Physiol. 2007; 213 (1): 98 - 104.

Sun QY, Miao YL, Schatten H. Towards a new understanding on the regulation of mammalian oocyte meiosis resumption. Cell Cycle. 2009; 8 (17): 2741 - 2747.

Sun QY, Nagai T. Molecular Mechanisms Underlying Pig Oocyte Maturation and Fertilization. J. Reprod. Dev. 2003; 49: 347 - 359.

Sun QY, Schatten H. Regulation of dynamic events by microfilaments during oocyte maturation and Fertilization. Reproduction. 2006; 131: 193 - 205.

Sunderman FW. The influence of zinc on apoptosis. Ann Clin Lab Sci. 1995; 25: $134-142$.

Sutovsky P \& Schatten G. Depletion of glutathione during bovine oocyte maturation reversibly blocks the decondensation of the male pronucleus and pronuclear apposition during fertilization. Biology of Reproduction. 1997; 56: 1503 - 1512. 
Sutton ML, Gilchrist RB, Thompson JG. Effects of in-vivo and in-vitro environments on the metabolism of the cumulus-oocyte complex and its influence on oocyte developmental capacity. Human Reproduction Update. 2003; 9: 35 - 48.

Sutton-McDowall M, Gilchrist R, Thompson J. The pivotal role of glucose metabolism in determining oocyte developmental competence. Reproduction. 2010; 139: 685 - 695.

Szybek K. In vitro maturation of oocytes from sexually immature mice. J. Endocrinol. 1972; 54: $527-528$.

Takahashi M, Nagai T, Hamano S, Kuwayama M, Okamura N, Okano A. Effect of thiol compounds on in vitro development and intracellular glutathione content of bovine embryos. Biol Reprod. 1993; 49 (2): 228 - 232.

Tamarin RH. Meiosis. En: Principios de genética. Editorial Reverté SA, Barcelona, 1996, p. 52 56.

Taneja M, Bols PEG, Van de Velde A, Ju JC, Schreiber D, Tripp DW, Levine H, Echelard Y, Riesen J, Yang X. Developmental Competence of Juvenile Calf Oocytes In Vitro and In Vivo: Influence of Donor Animal Variation and Repeated Gonadotropin Stimulation. Biol. Reprod. 2000; 62 (1): 206 - 213.

Tanghe S, Van Soom A, Nauwynck H, Coryn M, de Kruif A. Minireview: Functions of the cumulus oophorus during oocyte maturation, ovulation, and fertilization. Mol Reprod Dev. 2002; $61: 414-424$.

Tapiero $\mathrm{H}$, Tew KD. Trace elements in human physiology and pathology: zinc and metallothioneins. Biomed Pharmacother. 2003; 57 (9): 399 - 411. 
Taylor CG, Bettger WJ, Bray TM. Effect of dietary zinc or copper deficiency on the primary free radical defense system in rats. J Nutr. 1988; 118: $613-621$.

Taylor CG, Bray TM. Effect of hyperoxia on oxygen free radical defense enzymes in the lung of zinc-deficient rats. J Nutr. 1991; 121: 460 - 466.

Taylor CM, Bacon JR, Aggett PJ, Bremner I. Homeostatic regulation of zinc absorption and endogenous losses in zinc-deprived men. Am J Clin Nutr. 1991; 53 (3): 755 - 763.

Tervit HR, WhittinghamDG, Rowson LEA. Successful cultura in vitro of sheep and cattle ova. J Reprod Fertil. 1972; 30: 493 - 497.

Thibier M. Transfers of both in vivo derived and in vitro produced embryos in cattle still on the rise and contrasted trends in other species in 2005. Int Embryo Transfer Soc Newslett. 2006; 24: 12 - 18.

Tian X, Diaz FJ. Zinc Depletion Causes Multiple Defects in Ovarian Function during the Periovulatory Period in Mice. Endocrinology. 2012; 153 (2): 873 - 886.

Tice RR, Strauss GH. The single cell gel electrophoresis/comet assay: a potential tool for detecting radiation-induced DNA damage in humans. Stem Cells. 1995; 1: 207 - 214.

Tingen C, Kim A, Woodruff TK. The primordial pool of follicles and nest breakdown in mammalian ovaries. Molecular Human Reproduction. 2009; 15, No.12: 795 - 803.

Todd WR, Elvehjem CA, Hart EB. Zinc in the nutrition of the rat. American Journal of Physiology. 1934; 107: $146-156$. 
Tomikawa J, Homma T, Tajima S, Shibata T, Inamoto Y, Takase K, Inoue N, Ohkura S, Uenoyama Y, Maeda K, Tsukamura H. Molecular characterization and estrogen regulation of hypothalamic KISS1 gene in the pig. Biol Reprod. 2010; 82 (2): 313 - 319.

Torres Acosta R, Bahr Valcarcel P. El zinc: la chispa de la vida. Revista cubana de pediatría. $2004 ; 76$ (4).

Tosti E. Calcium ion currents mediating oocyte maturation events. Reprod Biol Endocrinol. 2006; 4: 26.

Toyoda Y, Yokoyama M, Hoshi T. Studies on the fertilization of mouse eggs in vitro. Jpn J Anim. Reprod. 1971; 16: 147-157.

Trounson A. The production of rumiant embryos in vitro. Anim Reprod Sci. 1992; 28 : 125 -137.

Trounson A, Anderiesz C, Jones G. Maturation of human oocytes in vitro and their developmental competence. Reproduction. 2001; 121: 51 - 75.

Truong-Tran AQ, Ho LH, Chai F and Zalewski PD. Cellular zinc fluxes and the regulation of apoptosis/gene-directed cell death. J Nutr. 2000; 130: 1459 - 1466.

Tsafriri A. Ovulation as a tissue remodelling process. Proteolysis and cumulus expansion. Adv Exp Med Biol. 1995; 377: 121 - 140.

Underwood EJ, Suttle NF. Zinc. En: The Mineral Nutrition of Livestock. CABI Publishing. London, UK, 1999, p. 477 - 512.

Urner F, Herman W, Baulien E, Schorderet-Slatkine S. Inhibition of denuded mouse oocyte maturation of forskolin, an activator of adenylate cyclase. Endocrinology. 1983; 113: 1170 $-1172$. 
Vallee BL, Falchuk KH. The biochemical basis of zinc physiology. Physiol. Rev. 1993; 73 : 79 118.

van den Hurk R, Bevers MM, Dieleman SJ. En: Joy KP, Krishna A, Haldar C (Eds.). Comparative endocrinology and reproduction. New Delhi: Narosa Publishing House, 1999, p. $296-312$.

van den Hurk R, Dijkstra G, van Mil FN, Hulshof SCJ, van den Ingh TSGA. Distribution of the intermediate filament proteins vimentin, keratin and desmin in the bovine ovary. Mol Reprod Dev. 1995; 41: 459 - 467.

van den Hurk R, Zhao J. Formation of mammalian oocytes and their growth, differentiation and maturation within ovarian follicles. Theriogenology. 2005; 63: $1717-1751$.

Vanderhyden B. Molecular basis of ovarian development and function. Front Biosci. 2002; 7 : $2006-2022$.

Vanderhyden BC. Species differences in the regulation of cumulus expansion by an oocytesecreted factor(s). J Reprod Fertil. 1993; 98: 219 - 227.

Vassalli JD, Huarte J, Belin J, Gubler P, Vassalli A, O'Connell ML, Parton LA, Rickles RJ, Strickland S. Regulated polyadenylation controls mRNA translation during meiotic maturation of mouse oocytes. Genes Dev. 1989; 3: 2163 - 2171.

Visconti PE, Galantino-Homer H, Moore GD, Bailey JL, Ning X, Fornes M, Kopf GS. The Molecular Basis of Sperm Capacitation. Journal of Andrology. 1998; 19: 242 - 248. 
Vozzi C, Formenton A, Chanson A, Senn A, Sahli R, Shaw P, Nicod P, Germond M, Haefliger JA. Involvement of connexin 43 in meiotic maturation of bovine oocytes. Reproduction. 2001; 122: $619-628$.

Wallace RA, Misulovin Z. The role of zinc and follicle cells in insulininitiated meiotic maturation of Xenopus laevis oocytes. Science. 1980; 210: 928 - 930.

Wan PC, Hao ZD, Zhou P, Wu Y, Yang L, Cui MS, Liu SR, Zeng SM. Effects of SOF and CR1 media on developmental competence and cell apoptosis of ovine in vitro fertilization embryos. Anim Reprod Sci. 2009; 114: 279 - 288.

Wang JYJ. DNA damage and apoptosis. Cell Death and Differentiation. 2001, 8: 1047 - 1048.

Wang K, Zhou B, Kuo YM, Zemansky J, Gitschier J. A novel member of a zinc transporter family is defective in acrodermatitis enteropathica. Am. J. Hum. Genet. 2002; 71(1): 66 - 73.

Wang LY, Wang DH, Zou XY, Xu CM. Mitochondrial functions on oocytes and preimplantation embryos. J Zhejiang Univ Sci B. 2009; 10 (7): 483 - 492.

Wang WH, Abeydeera LR, Cantley TC, Day BN. Effects of oocyte maturation media on development of pig embryos produced by in vitro fertilization. J Reprod Fertil. 1997; 111: $101-108$.

Washabaugh MW, Collins KD. Dihydroorotase from Escherichia coli. Sulfhydryl group-metal ion interactions. J Biol Chem. 1986; 261: 5920 - 5229.

Wassarman P, Letorneau G. RNA synthesis in fully-grown mouse oocytes. Nature. 1976; 361: $73-74$. 
Wassarman P, Schultz R, Letorneau G, La Marca M, Bleil J. Meiotic maturation of mouse oocytes in vitro. En: Channing C, Marsh J, Sadler W (Eds) Ovarian folicular and corpus luteum function. Plenum Press, New York, USA, 1979, p. 251 - 268.

Wassarman PM. Profile of a mammalian sperm receptor. Development. 1990; 108: 1 - 17.

Wassarman PM, Mortillo S. Structure of the mouse egg extracellular coat, the zona pellucid. Int Rev Cytol. 1991; 130: 85 - 110.

Watanabe N, Hunt T, Ikawa Y, Sagata. Independent inactivation of MPF and cytostatic factor (MOS) upon fertilization on Xenopus eggs. Nature. 1991; 352: 247 - 249.

Watson AJ. Oocyte cytoplasmic maturation: a key mediator of oocyte and embryo developmental competence. J Anim Sci. 2007; 85 (13): 1 - 3.

Webb R, Campbell BK, Garverick HA, Gong JG, Gutierrez CG, Armstrong DG. Molecular mechanisms regulating follicular recruitment and selection. J Reprod Fertil Suppl. 1999; 54: $33-48$.

Weisiger RA, Fridovich I. Mitochondrial superoxide dismutase. J. Biol. Chem. 1973; 248: 4793 4796.

Wertheimer EV, Salicioni AM, Liu W, Trevino CL, Chavez J, Hernández-González EO, Darszon A, Visconti PE. Chloride Is essential for capacitation and for the capacitation-associated increase in tyrosine phosphorylation. J Biol Chem. 2008; 283 (51): 35539 - 35550.

Westerndorf JM, Swenson KI, Ruderman JV. The role of cyclin B in meiosis. J Cell Biol. 1989; 108: 1431 - 1444.

Whitaker M. Control of meiotic arrest. Rev Repr. 1996; 1: 127 - 135. 
Whitaker M, Patel R. Calcium and cell cycle control. Development. 1990, 108: 525 - 542.

Whittingham DG. In vitro fertilization, embryo transfer and storage. Br Med Bull. 1979; 35: 105.

Wickramasinghe D, Ebert KM, Albertini DF. Meiotic competence acquisition is associated with the appearance of M-phase. Characteristic in growing mouse oocytes. Dev Biol. 1991; 143: $162-172$.

Wilson RD, Weigel KA, Fricke PM, Rutledge JJ, Leibfried-Rutledge ML, Matthews DL, Schutzkus VR. In vitro production of Holstein embryos using sex-sorted sperm and oocytes from selected cull cows. J Dairy Sci. 2005; 88 (2): 776 - 782.

Wongsrikeao $\mathrm{P}$, Kaneshige $\mathrm{Y}$, Ooki R, Taniguchi M, Agung B, Nii M, Otoi T. Effect of the removal of cumulus cells on the nuclear maturation, fertilization and development of porcine oocytes. Reprod Domest Anim. 2005; 40: 166 - 170.

Woods JS, Ellis ME. Up-regulation of glutathione synthesis in rat kidney by methyl mercury. Relationship to mercury -induced oxidative stress. Biochem Pharmacol. 1995; 50: 1719 1724.

Wrightt CL, Spears JW. Effect of zinc source and dietary level on zinc metabolism in Holstein calves. J Dairy Sci. 2004; 87 (4): 1085 - 1091.

Wyllie AH, Kerr J, Fand Currie AR. Cell death: the significance of apoptosis. Int. Rev. Cytol. 1980; 68: $251-306$.

Yamaguchi S, Miura C, Kikuchi K, Celino FT, Agusa T, Tanabe S, Miura T. Zinc an essential trace element for spermatogenesis. Proc Natl Acad Sci USA. 2009; 106: 10859 - 10864. 
Yamanaka Y, Ralston A, Stephenson RO, Rossant J. Cell and Molecular Regulation of the Mouse Blastocyst. Developmental Dynamics. 2006; 235: 2301 - 2314.

Yamasaki S, Sakata-Sogawa K, Hasegawa A, Suzuki T, Kabu K, Sato E, Kurosaki T, Yamashita S, Tokunaga M, Nishida K, Hirano T. Zinc is a novel intracellular second messenger. J Cell Biol. 2007; 177 (4): 637 - 645.

Yanagimachi R. Mammalian fertilization. En: Knobil E, Neil SD (Eds.) The Physiology of Reproduction. New York, USA, Raven Press, 1994, p. 245 - 247.

Yanagimachi R. Mammalian Sperm Acrosome Reaction: Where Does It Begin Before Fertilization? Biol Reprod. 2011; 85: 4 - 5.

Yanagimachi R, Phillips DM. The status of acrosomal caps of hamster spermatozoa immediately before fertilization in vivo. Gamete Res. 1984; 9: 1 - 19.

Yanagimachi R, Usui N. Calcium dependence of the acrosome reaction and activation of guinea pig spermatozoa. Exp Cell Res. 1974; 89 (1): 161 -174.

Yang MY, Rajamahendran R. Morphological and biochemical identification of apoptosis in small, medium, and large bovine follicles and the effects of follicle-stimulating hormone and insulin-like growth factor-I on spontaneous apoptosis in cultured bovine granulosa cells. Biology of Reproduction. 2000; 62: 1209 - 1217.

Yoshida M. Role of glutathione in the maturationand fertilization of pig oocytes in vitro. Mol Reprod Dev. 1993; 35: 76 - 81. 
Yoshida M, Ishigaki K, Nagai T, Chikyu M, Pursel VG. Glutathione concentration during maturation and after fertilization in pig oocytes relevance to the ability of oocytes to form male pronucleus. Biol Reprod. 1993; 49: 89 - 94.

Yoshida M, Ishigaki K, Pursel VG. Effect of Maturation Media on male pronucleus formation in pig oocytes matured in vitro. Mol Reprod Dev. 1992a; 31: 68 - 71.

Yoshida M, Ishizaki Y, Kawagishi H, Bamba K, Kojima Y. Effects of pig follicular fluid on maturation of pig oocytes in vitro and on their subsequent fertilizing and developmental capacity in vitro. J. Reprod. Fert. 1992b; 95: 481 - 488.

Young JM, McNeilly AS. Theca: the forgotten cell of the ovarian follicle. Reproduction. 2010; 140: $489-504$.

Yousef MI, El-Hendy HA, El-Demerdash FM, Elagamy El. Dietary zinc deficiency inducedchanges in the activity of enzymes and the levels of free radicals, lipids and protein electrophoretic behavior in growing rats. Toxicology. 2002; 175: 223 - 234.

Yudin Al, Cherr GN, Katz DF. Structure of the cumulus matrix and zona pellucida in the golden hamster: a new view of sperm interaction with oocyte-associated extracellular matrices. Cell Tissue Res. 1988; 251(3): 555 - 564.

Zeleznik AJ. Premature elevation of systemic estradiol reduces serum levels of folliclestimulating hormone and lengthens the follicular phase of the menstrual cycle in rhesus monkeys. Endocrinology. 1981; 2: 352 - 355.

Zhang M, Ouyang H, Xia G. The signal pathway of gonadotrophins induced mammalian oocyte meiotic resumption. Molecular Human Reproduction. 2009; 15 (7): 399 - 409. 
Zhao J, Taverne MA, van der Weijden GC, Bevers MM, van den Hurk R. Effect of activin A on in vitro development of rat preantral follicles and localization of activin A and activin receptor II. Biol Reprod. 2001; 65: 967 - 977.

Zheng YG, Sirard MA. Theeffect of sera, bovine serum albumin and follicular cells on in vitro maturation and fertilization of porcine oocyte. Theriogenology. 1992; 37: 779 -790.

Zuckerman S, Baker T. The development of the ovary and the process of oogenesis. En: Zuckerman S, Weir B (Eds) The ovary. Vol 1. Academic Press, New York, USA, 1977, p. $48-68$.

Zuelke KA, Brackett BG. Increased Glutamine Metabolism in Bovine Cumulus Cell-Enclosed and Denuded Oocytes after In Vitro Maturation with Luteinizing Hormone. Biology of Reproduction. 1993; 48: 815 - 820.

Zuelke KA, Jones DP, Perreault SD. Glutathione oxidation is associated with altered microtubule function and disrupted fertilization in mature hamster oocytes. Biol Reprod. 1997; 57: 1413-1419. 